\title{
STEFANIE KRASCHOWETZ
}

Clonagem, produção e purificação de uma molécula recombinante híbrida estável de duas proteínas de Streptococcus pneumoniae unidas por espaçador molecular: PspA94-PdT

Tese apresentada ao Programa de PósGraduação Interunidades em Biotecnologia da Universidade de São Paulo, Instituto Butantan e Instituto de Pesquisas Tecnólogicas para obtenção do Título de Doutor em Biotecnologia. 





\section{STEFANIE KRASCHOWETZ}

Clonagem, produção e purificação de uma molécula recombinante híbrida estável de duas proteínas de Streptococcus pneumoniae unidas por espaçador molecular: PspA94-PdT

Tese apresentada ao Programa de PósGraduação Interunidades em Biotecnologia da Universidade de São Paulo, Instituto Butantan e Instituto de Pesquisas Tecnólogicas para obtenção do Título de Doutor em Biotecnologia.

Área de concentração: Biotecnologia

Orientadora: Dra. Viviane Maimoni Gonçalves

Versão corrigida. A versão original eletrônica encontra-se disponível tanto na biblioteca do ICB quanto na Biblioteca Digital de Teses e Dissertações da USP (BDTD). 


\section{CATALOGAÇÃO NA PUBLICAÇÃO (CIP) \\ Serviço de Biblioteca e informação Biomédica \\ do Instituto de Ciências Biomédicas da Universidade de São Paulo}

Ficha Catalográfica elaborada pelo(a) autor(a)

Kraschowetz, Stefanie

Clonagem, produção e purificação de uma molécula recombinante híbrida estável de duas proteínas de Streptococcus pneumoniae unidas por espaçador molecular: PspA94-PdT / Stefanie Kraschowetz; orientador Viviane Maimoni Gonçalves. -- São Paulo, 2018 .

$188 \mathrm{p}$.

Tese (Doutorado)) -- Universidade de São Paulo, Instituto de Ciências Biomédicas.

1. Streptococcus pneumoniae. 2. Proteína de superfície A do pneumococo (PspA). 3. Pneumolisina detoxificada (PdT). 4. Proteína de fusão. 5.

Espaçador molecular. I. Gonçalves, Viviane Maimoni, orientador. II. Título. 


\section{UNIVERSIDADE DE SÃO PAULO \\ Programa de Pós-Graduação Interunidades em Biotecnologia}

Universidade de São Paulo, Instituto Butantan, Instituto de Pesquisas Tecnológicas

Candidato(a): $\quad$ Stefanie Kraschowetz

Título da Tese: Clonagem, produção e purificação de uma molécula recombinante híbida estável de duas proteínas de Streptococcus pneumoniae unidas por espaçador molecular: PspA94-PdT

Orientador(a): $\quad$ Dra. Viviane Maimoni Gonçalves

A Comissão Julgadora dos trabalhos de Defesa da Tese de Doutorado, em sessão pública realizada a ...................., considerou

\section{( ) Aprovado(a) ( ) Reprovado(a)}

$\begin{array}{ll}\text { Examinador(a): } & \text { Assinatura: } \\ & \text { Nome: ........ } \\ & \text { Instituição: ... } \\ \text { Examinador(a): } & \text { Assinatura: } \\ & \text { Nome: ....... } \\ & \text { Instituição: } \\ \text { Examinador(a): } & \text { Assinatura: } \\ & \text { Nome: ........ } \\ & \text { Instituição: ... } \\ & \text { Assinatura: } \\ \text { Examinador(a): } & \text { Nome: ........ } \\ & \text { Instituição: ... } \\ & \text { Assinatura: } \\ \text { Presidente: } & \text { Nome: .......... } \\ & \text { Instituição: ... }\end{array}$





\section{il butantan \\ Comissão de Ética no Uso de Animais}

\section{CERTIFICADO}

Certificamos que o Projeto intitulado "Produção de uma molécula recombinante híbrida de duas proteínas de Streptococcus pneumoniae: PspA94-PdT", protocolado sob o CEUA no 5739290116, sob a responsabilidade de Viviane Maimoni Gonçalves e equipe; Celia Liberman; Stefanie Kraschowetz - que envolve a produção, manutenção e/ou utilização de animais pertencentes ao filo Chordata, subfilo Vertebrata (exceto o homem), para fins de pesquisa científica (ou ensino) - encontra-se de acordo com os preceitos da Lei 11.794, de 8 de outubro de 2008, com o Decreto 6.899, de 15 de julho de 2009, com as normas editadas pelo Conselho Nacional de Controle da Experimentação Animal (CONCEA), e foi aprovado pela Comissão de Ética no Uso de Animais do Instituto Butantan da Instituto Butantan (CEUAIB) em reunião de 16/03/2016.

We certify that the proposal "Production of a hybrib molecule of two proteins from Streptococcus pneumoniae: PspA94-PdT", utilizing 48 Inbred mice (48 females), protocol number CEUA 5739290116, under the responsibility of Viviane Maimoni Gonçalves and team; Celia Liberman; Stefanie Kraschowetz - which involves the production, maintenance and/or use of animals belonging to the phylum Chordata, subphylum Vertebrata (except human beings), for scientific research purposes (or teaching) it's in accordance with Law 11.794, of October 8 2008, Decree 6899, of July 15, 2009, with the rules issued by the National Council for Control of Animal Experimentation (CONCEA), and was approved by the Ethic Committee on Animal Use of the Butantan Institute (CEUAIB) in the meeting of 03/16/2016.

Vigência da Proposta: de 03/2016 a 12/2016

Área: Centro De Biotecnologia

Procedência: Não se aplica

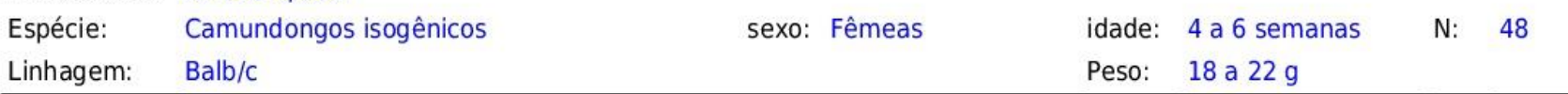

Resumo: Streptococcus pneumoniae é causa de doenças como pneumonia, otite, sinusite, meningite e sepse. Devido ao grande número de sorotipos da bactéria, cada um deles com um polissacarídeo capsular diferente e cuja distribuição na população varia, as vacinas hoje disponíveis têm cobertura limitada e está ocorrendo substituição de sorotipos na população por outros não presentes nas vacinas. Visando reduzir o custo e aumentar a cobertura, têm-se estudado vacinas baseadas em proteínas que dariam proteção sorotipo-independente. Dentre elas, a proteína de superfície do pneumococo (PspA) e a pneumolisina geneticamente detoxificada (PdT) mostraram resultados promissores em modelos de septicemia e a utilização combinada das duas apresentou o maior potencial protetor contra desafio sistêmico em camundongos. Durante o desenvolvimento do processo de purificação para a proteína recombinante híbrida PspA94-PdT, produzida em E. coli M15 com cauda de histidina N-terminal, foi verificado que a proteína estava sofrendo quebra entre as proteínas que formam o híbrido. Para superar este problema, este projeto propõe a construção de novos híbridos que contenham espaçadores entre as proteínas, visando aumentar a estabilidade a molécula. Desta forma, o objetivo deste trabalho é produzir uma proteína híbrida de PspA94-PdT em E. coli BL21(DE3) com cauda de histidina C-terminal adequada para utilização em novas vacinas pneumocócicas proteicas e assim oferecer proteção independente do sorotipo. Será estudada a influência de diferentes tipos de espaçadores, rígido e flexível, na estrutura, estabilidade e características físico-químicas dos híbridos. 0 híbrido que se mostrar mais estável será então produzido em reatores e purificado em escala de bancada.

São Paulo, 25 de abril de 2016

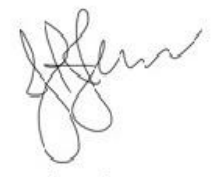

Jose Ricardo Jensen

Coordenador da Comissão de Ética no Uso de Animais Instituto Butantan

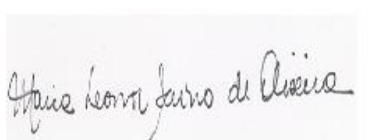

Maria Leonor Sarno de Oliveira Vice-Coordenadora da Comissão de Ética no Uso de Animais Instituto Butantan 

Dedico este trabalho à minha amada mãe, Eliane. Minhas conquistas sempre serão antes suas do que minhas. 



\section{AGRADECIMENTOS}

Agradeço, antes de mais nada, a Deus.

Agradeço a CAPES pelo apoio financeiro.

Agradeço minha orientadora Viviane Gonçalves, pela orientação sempre presente, carinhosa e paciente. Que sorte a minha poder ter passado pelo doutorado com a sua orientação, conselhos e puxões de orelha quando era preciso! É muito bom trabalhar com alguém que admiramos e temos como exemplo. $O$ mundo acadêmico certamente seria outro, muito melhor, se houvesse mais Vivianes por aí...

Agradeço minha co-orientadora informal, Célia Liberman. Muito obrigada por toda ajuda com os experimentos com camundongos e muito obrigada por todas as conversas sobre os mais diversos assuntos. Não teria conseguido sem a sua ajuda tão carinhosa e agradável!

Agradeço a Dra. Kelsy Areco, da Unifesp, pela valiosa ajuda com a parte estatística dos meus experimentos com animais. Muito obrigada por ajudar a tornar as análises e conclusões tão claras para mim.

Agradeço também aos pesquisadores do Butantan: Dra. Ana Maria Moura da Silva, pela ajuda com os testes de presença de proteases; Dr. Rafael Marques Porto, pela ajuda com o sequenciamento $\mathrm{N}$-terminal do fragmento da minha proteína e Dra. Giovanna Barazzone, por me emprestar a coluna cromatográfica de Superose 12.

Agradeço a todos que direta ou indiretamente contribuíram para que esse trabalho fosse executado.

Aos meus queridos amigos de laboratório, de churrascos e de "Boteco do Pneumophilus" Douglas, Rafaela, Fara, Camila, Mariana, Felipe, Paola, Bruno e Geovanna: meu mais sincero e profundo obrigada! Obrigada pela ajuda com os experimentos, pela ajuda psicológica, pelo companheirismo, pela amizade. Guardo vocês no coração e torcerei sempre pelo sucesso e felicidade de vocês. Dos presentes que o Butantan me trouxe, vocês são os mais preciosos!

Agradeço muito minha amiga Juliana Medeiros Pinheiro. Minha amiga de infância, amiga de adolescência, amiga de meia-idade, amiga desde sempre e para 
sempre. Muito obrigada por ouvir meus lamentos e me ajudar a perseverar na pósgraduação. Sua amizade é um lindo presente de Deus!

Ao meu irmão Nikolas e minha avó Sonia, muito obrigada pela cia, pelos fins de semana, churrascos e passeios. Como é bom ter uma família linda e unida para nos acolher. Minha família é demais, amo vocês!

Minha mãe é a maior entusiasta de todos os meus projetos. Aquela que nos ajuda - eu e meu irmão - a acreditar em nós mesmos, a correr atrás e realizar tudo que, a princípio, são só desejos e planos. Deus foi muito bondoso em me deixar nascer de uma mulher tão admirável. Obrigada mãe, mais uma vez, por estar sempre presente, sempre positiva e sempre nos impulsionando a ir atrás dos nossos desejos. Amo muito!

Conheci meu marido, Renato, quando estava ingressando no mestrado. Hoje, finalizando o doc, estamos nós recém-casados! A ele, que aguentou de perto todos os dramas, todas as dificuldades, todos os Natais, feriados e fins de semana de trabalho e também todas as vitórias, meu mais sincero e profundo: obrigada! Saiba que a vida é muito mais gostosa ao seu lado. Obrigada pela paciência inesgotável, obrigada pelo enorme apoio ao longo desses anos e obrigada por tudo que ainda está por vir... Daqui até a eternidade, te amo!

Termino dizendo que esses anos foram ótimos. Apesar da falta de dinheiro, das bolsas atrasadas, do estresse com os experimentos que (quase) sempre dão errado, e dos feriados trabalhando, foi muito prazeroso poder me dedicar a este trabalho. Desejo que todos um dia possam ter esse sentimento na vida, de chegar domingo à noite e pensar: que delícia, amanhã vou trabalhar! 
"Vós dizeis: os tempos são difíceis, são tempos duros, tempos de desgraças. Vivei bem e, com uma vida boa, mudai os tempos. O tempo não prejudicou ninguém. Os que são prejudicados são os homens e aqueles de quem recebem os danos são homens. Portanto, mudai o homem e mudarão os tempos" (Santo Agostinho - Sermão 311, 8) 



\section{RESUMO}

KRASCHOWETZ, S. Produção de uma molécula recombinante híbrida de duas proteínas de Streptococcus pneumoniae: PspA94-PdT. 2018. 189 p. Tese (Doutorado em Biotecnologia) - Instituto de Ciências Biomédicas, Universidade de São Paulo, São Paulo, 2018.

Streptococcus pneumoniae é causa de doenças como pneumonia, otite, meningite e sepse. As vacinas hoje disponíveis têm cobertura limitada porque são baseadas no polissacarídeo capsular, que varia com os mais de 90 sorotipos da bactéria, além de levarem à substituição de sorotipos na população por outros não presentes nas formulações. Visando reduzir o custo e aumentar a cobertura, têm-se estudado vacinas baseadas em proteínas que ofereceriam proteção independente de sorotipo. Este trabalho teve por objetivo a obtenção, avaliação da estabilidade e da resposta imune em camundongos de híbridos de duas proteínas de $S$. pneumoniae: a proteína de superfície do pneumococo (PspA) e a pneumolisina geneticamente detoxificada (PdT), sem ou com espaçadores moleculares, rígido ou flexível, entre as moléculas. Os genes dos híbridos com espaçadores foram clonados através da técnica de overlap extension PCR. O gene das proteínas foi expresso em E. coli e as proteínas obtidas foram reconhecidas por anticorpos produzidos contra a célula inteira de pneumococo através de Western Blot. A purificação dos híbridos foi feita utilizando homogeneizador de alta pressão, precipitação de impurezas com detergente catiônico CTAB e diferentes etapas cromatográficas. A estabilidade foi analisada periodicamente através de SDS-PAGE e Western Blot. O híbrido sem espaçador mostrou-se instável, por isso a presença de atividade proteolítica foi investigada através de diversos ensaios para detecção dessas enzimas, mostrando que a instabilidade não decorreu de hidrólise por proteases. Os fragmentos resultantes da quebra tiveram a porção N-terminal sequenciada para identificar o sítio de clivagem, que estava localizado na junção das duas proteínas. Esse sítio foi retirado das construções seguintes e espaçadores moleculares foram incluídos entre os dois antígenos. A molécula com espaçador flexível foi obtida na forma solúvel durante o cultivo, porém durante a purificação ocorreu precipitação irreversível. O clone para produção do híbrido com espaçador rígido permitiu a obtenção da proteína, que foi purificada e teve a estabilidade avaliada periodicamente à $4^{\circ} \mathrm{C}$ e $-20^{\circ} \mathrm{C}$ por Western Blot empregando anticorpos contra célula inteira de pneumococo, indicando que a 
introdução do espaçador rígido aumentou a estabilidade do híbrido em relação à molécula sem espaçador. Além disso, diferentes concentrações de estabilizantes foram avaliadas, mostrando que em presença de trealose $1 \mathrm{M}$ ou glicerol $50 \%$ o híbrido com linker rígido permaneceu estável por pelo menos 4 meses a $4^{\circ} \mathrm{C}$. A molécula com espaçador rígido produziu níveis de anticorpos em camundongos comparáveis aos níveis obtidos com a molécula sem espaçador, que foram capazes de proteger $100 \%$ dos animais em ensaio de desafio letal intranasal e inibir a atividade hemolítica da pneumolisina. O aumento de estabilidade do híbrido alcançado com a inserção do linker rígido juntamente com a retirada do sítio de clivagem e com a presença de estabilizantes permitem que esta molécula seja utilizada numa vacina pneumocócica proteica. Como estudos vêm demonstrando que seria necessário mais de uma proteína para formular esta nova vacina, a produção deste híbrido traz a grande vantagem de obtenção de dois antígenos em um único processo de produção, o que pode resultar em uma diminuição do custo da dose.

Palavras-chave: Streptococcus pneumoniae. Proteína de superfície A do pneumococo (PspA). Pneumolisina detoxificada (PdT). Proteína de fusão. Espaçador molecular. 


\begin{abstract}
KRASCHOWETZ, S. Production of a recombinant hybrid molecule composed of two proteins of Streptococcus pneumoniae: PspA94-PdT 2018. 189 p. Thesis (Ph. D. thesis in Biotechnology) - Instituto de Ciências Biomédicas, Universidade de São Paulo, São Paulo, 2018.

Streptococcus pneumoniae is cause of diseases like pneumonia, otitis, menngitis and sepsis. The vaccines available nowadays has limited coverage because they are based on the capsular polysaccharyde, which varies among the more than 90 bacteria serotypes and they lead to serotype substitution on the population for others not present on the vaccine formulations. In order to reduce the cost and increase the coverage, vaccines based on pneumococcal proteins that would offer serotype independent protection have been studied. The objective of this thesis was the obtainment, stability evaluation and immune response evaluation in mice of hybrids composed of two proteins of $S$. pneumoniae: pneumococcal surface protein A (PspA) and genetically detoxified pneumolysin (PdT), with or without molecular linkers, rigid and flexible, between the molecules. The genes with molecular linkers were cloned using the overlap extension PCR technique. The genes were expressed in $E$. coli and the proteins were recognized by anti pneumococcal whole cell in Western Blot. The hybrids were purified using high pressure homogeneizer, precipitation of impurities using cationic detergent CTAB and different chromatography steps. The stability was periodically analyzed through SDS-PAGE and Western Blot. The hybrid without linker was unstable and the presence of proteolytic activity was investigated through several methods for protease activity detection, showing that instability was not due to protease hydrolysis. The $\mathrm{N}$-terminal portion of the degraded protein fragments was sequenced in order to identify the cleavage site, which was localized exactly between the two proteins. This site was removed from the other hybrids and molecular linkers were included between the two antigens. The molecule with flexible linker was obtained on the soluble form during expression, but during purification it precipitated irreversibly. The molecule with rigid linker were expressed, purified and had its stability analyzed periodically at $4^{\circ} \mathrm{C}$ and $-20^{\circ} \mathrm{C}$ by Western Blot using anti pneumococcal whole cell, indicating that the insertion of the rigid linker increased the hybrid stability when compared with the hybrid without linker. Besides that, different stabilizers in different concentrations were evaluated and it was found that the presence of trehalose
\end{abstract}


$1 \mathrm{M}$ or $50 \%$ glycerol stabilized the hybrid with rigid linker for at least 4 months at $4{ }^{\circ} \mathrm{C}$. The molecule with rigid linker produced levels of antibodies in mice comparable to the hybrid without linker. These antibodies were able to protect $100 \%$ of animals from lethal intranasal challenge and inhibit the haemolytic activity of pneumolysin. The stability increase due to the rigid linker together with the removal of the cleavage site and the stabilizers presence allow this hybrid molecule to be used on a novel pneumococcal vaccine. Since studies have shown that it would be necessary more than one protein to formulate this new vaccine, the production of this hybrid brings the great advantage of producing two antigens in one single process, which can decrease the dosage cost.

Keywords: Streptococcus pneumoniae. Pneumococcal surface protein A (PspA). Detoxified pneumolysin (PdT). Fusion protein. Molecular linker. 


\section{LISTA DE FIGURAS}

Figura 1 - Streptococcus pneumoniae. A. Bactérias em cadeia curta vistas por microscopia eletrônica de varredura, barra $=1 \mu \mathrm{m}, \mathrm{B}$. Diplococo visto por microscopia eletrônica de transmissão, barra $=0,5 \mu \mathrm{m}$. O asterisco indica a cápsula polisacarídica. 36

Figura 2 - Esquema da estrutra da PspA. A molécula de PspA possui a região Nterminal rica em $\alpha$-hélice $(A$ e $B$ ) que contém a região $C D R$ (definidora de clado), a região rica em prolina $(C)$ e o domínio de ligação à colina.

Figura 3 - Estrutura da pneumolisina. a) Representação em fitas. b) Representação eletrostática da superfície de Ply. As duas regiões eletronegativamente significativas estão indicadas por A e B. Vermelho indica potencial eletronegativo e azul indica potencial positivo.

Figura 4 - Representação esquemática de um homogeneizador de alta pressão....51

Figura 5 - Estrutura do detergente catiônico brometo de cetiltrimetilamonio (CTAB) .52

Figura 6 - Afinidade e especificidade de diferentes íons metálicos por histidinas ....54

Figura 7 - Esquema ilustrado de cromatografia de exclusão molecular .55

Figura 8 - Mecanismo de inserção dos espaçadores nas proteínas híbridas por overlap extension PCR. 65

Figura 9 - Mapa do vetor de clonagem pGEM-T esasy vector 66

Figura 10 - Mapa do vetor de expressão pET-28 ….........................................67

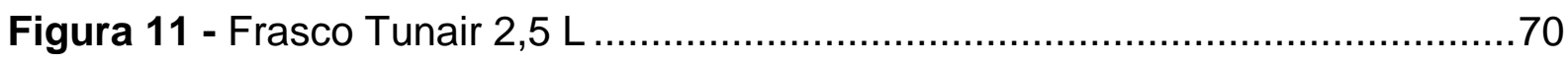

Figura 12 - Etapas do processo de purificação das proteínas híbridas ....................74

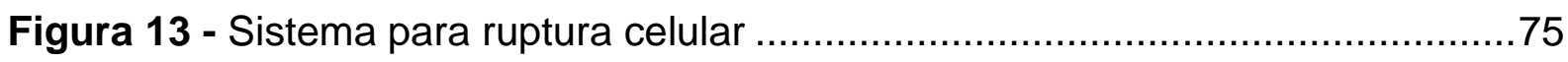

Figura 14 - Lise das células (Abs 600nm) e liberação de proteínas (Abs 280nm) do processo de purificação 01 88

Figura 15 - Teste de precipitação de impurezas com CTAB do processo de purificação 01. A flecha indica da concentração de $0,25 \%$ 89

Figura 16 - SDS-PAGE das amostras da purificação 01 da PspA-PdT. .90

Figura 17 - Lise das células (Abs 600nm) e liberação de proteínas (Abs 280nm) do processo de purificação 02 
Figura 18 - SDS-PAGE das amostras da purificação 02 da PspA-PdT. 92

Figura 19 - Mudança de perfil eletroforético da PspA-PdT purificada pelo processo 02 após 15 dias 93

Figura 20 - Ensaio de atividade proteolítica de amostras do processo de purificação 02. 94

Figura 21 - Western-Blot da PspA-PdT degradada revelado com anti-PspA94, com anti-extrato total de pneumococo e com anti-PdT 95

Figura 22 - Lise das células (Abs 600nm) e liberação de proteínas (Abs 280nm) do processo de purificação 03 96

Figura 23 - SDS-PAGE das amostras da purificação 03...................................... 98

Figura 24 - Western Blot das eluições do processo de purificação 03. 99

Figura 25 - Western Blot das eluições do processo de purificação 03 após 14 semanas a $-20 \stackrel{\circ}{C}$ 100

Figura 26 - Lise das células (Abs 600nm) e liberação de proteínas (Abs 280nm) do processo de purificação 04 101

Figura 27 - SDS-PAGE das etapas do processo de purificação 04 da PspA-PdT. 104

Figura 28 - Western Blot de amostras da purificação 04 da PspA-PdT após 9 semanas a $4 \stackrel{\circ}{\circ}$.

Figura 29 - Zimograma com amostras da purificação 04 da PspA-PdT na presença de gelatina $0,1 \%$. 106

Figura 30 - Zimograma com amostras da purificação 04 da PspA-PdT na presença de caseína $0,1 \%$. 106

Figura 31 - Ensaio de detecção de serinoproteases com substrato L-BAPNA nas amostras de purificação da PspA94-PdT com veneno de B. jararaca como controle positivo. 108

Figura 32 - Ensaio para detecção de metaloproteases com substrato Abz-AGLAEDDnp nas amostras de purificação da PspA94-PdT com jararagina isolada como controle positivo.

Figura 33 - Separação dos fragmentos da PspA94-PdT degradada por cromatografia de afinidade por metal 110

Figura 34 - Cromatograma da purificação por HPLC em coluna C4 dos fragmentos da PspA94-PdT degradada obtidos na fração não adsorvida da IMACSepharose. 
Figura 35 - Local principal de degradação na sequência de aminoácidos da PspA94PdT sem espaçador.

Figura 36 - Gel de agarose 1\% com o gene pspA94-FL amplificado nos poços A e B e com o gene FL-pdt amplificado nos poços C e D

Figura 37 - Gel de agarose $0,8 \%$ com o produto de PCR para amplificação do gene da pspA94-FL-pdT

Figura 38 - Gel de agarose 1\% mostrando a digestão do plasmídeo pGEM-T/pspA94FL-pdT purificado dos clones 1 a 7.

Figura 39 - Produtos de PCR para seleção dos clones de E. coli BL21 Star (DE3) pLysS carregando pET-28a/pspA94-FL-pdt em gel de agarose 0,8\%116

Figura 40 - SDS-PAGE das amostras dos cultivos de E. coli BL21 Star (DE3)pLysS para produção da proteína híbrida PspA94-FL-PdT.

Figura 41 - Western Blot amostras do cultivo de E. coli BL21 Star (DE3) pLysS para produção da proteína híbrida PspA94-FL-PdT.

Figura 42 - Teste de expressão gênica para produção de PspA94-FL-PdT em E. coli Rosetta (DE3)

Figura 43 - SDS-PAGE das amostras do cultivo do clone 2 de E. coli Rosetta (DE3) para produção da proteína híbrida PspA94-FL-PdT94.

Figura 44 - Western blotting das amostras do cultivo do clone 2 de E. coli Rosetta (DE3) para produção da proteína híbrida PspA94-FL-PdT

Figura 45 - Gel de agarose 1\% com o gene RL-pdt amplificado no poço A e com o gene pspA94-RL amplificado nos poços B, C e D

Figura 46 - Gel de agarose com o produto de PCR de amplificação do gene da proteína híbrida com espaçador rígido: pspA94-RL-pdT

Figura 47 - Gel de agarose 1\% mostrando a digestão do plasmídeo pGEM-T/pspA94$\mathrm{RL}$-pdT purificado dos clones 1 a 5.

Figura 48 - Produtos de PCR para seleção dos clones de E. coli BL21 Star (DE3)pLysS em gel de agarose $0,8 \%$. 125

Figura 49 - SDS-PAGE das amostras do cultivo de E. coli BL21 Star (DE3)pLysS, clone R4-VII, para produção da proteína híbrida PspA94-RL-PdT. .... 125

Figura 50 - Western Blot das amostras do cultivo de E. coli BL21 Star (DE3)pLysS para produção da proteína híbrida PspA94-RL-PdT. 126 
Figura 51 - Curva de crescimento de E. coli BL21 (DE3) com plasmídeo pET28a/pspA94-RL-pdt em $1 \mathrm{~L}$ de meio LB com canamicina em frasco Tunair agitado.

Figura 52 - Gráfico de $\ln (\mathrm{DO})$ pelo tempo para obtenção do valor de $\mu$ máx do cultivo de E. coli BL21 (DE3) com plasmídeo pET-28a/pspA94-RL-pdt em 1 L de meio LB em frasco Tunair agitado 128

Figura 53 - Gráfico de massa seca (g/L) por DO do cultivo de E. coli BL21 (DE3) com plasmídeo pET-28a/pspA94-RL-pdt em 1 L de meio LB em frasco Tunair agitado. 128

Figura 54 - Gráfico de $\ln (\mathrm{DO})$ pelo tempo para obtenção do valor de $\mu$ máx do cultivo de E. coli BL21 (DE3) com plasmídeo pET-28a/pspA94-RL-pdt em biorreator com meio CDM

Figura 55 - Gráfico do cultivo em biorreator de E. coli BL21 (DE3) para produção de PspA94-RL-PdT em $6 \mathrm{~L}$ de meio CDM no modo batelada. A seta verde indica o momento da indução. 130

Figura 56 - SDS-PAGE da fração solúvel das amostras do cultivo em biorreator de E. coli BL21 (DE3) para produção de PspA94-RL-PdT

Figura 57 - SDS-PAGE da purificação da PspA94-RL-PdT produzida em biorreator em E. coli BL21 Star (DE3) pLysS. 132

Figura 58 - SDS-PAGE e Western Blot das amostras da etapa de cromatografia de afinidade por $\mathrm{Ni2}+$ da PspA94-RL-PdT. 134

Figura 59 - Avaliação da estabilidade de PspA94-RL-PdT purificada após 1 semana de armazenamento.

Figura 60 - Avaliação da estabilidade de PspA94-RL-PdT purificada após 2 semanas de armazenamento.

Figura 61 - Avaliação da estabilidade de PspA94-RL-PdT purificada após 4 semanas de armazenamento.

Figura 62 - Avaliação da estabilidade de PspA94-RL-PdT purificada após 8 semanas de armazenamento.

Figura 63 - Avaliação da estabilidade de PspA94-RL-PdT purificada após 20 semanas de armazenamento.

Figura 64 - Avaliação da estabilidade de PspA94-RL-PdT purificada após 14 meses de armazenamento.

Figura 65 - Estabilidade da PspA94-RL-PdT a $4 \stackrel{\circ}{ } \mathrm{C}$ após 4 meses na presença ou ausência de estabilizantes 
Figura 66 - Cultivo de E. coli M15 para produção de PspA94-PdT em meio LBcan/amp.

Figura 67 - Purificação de PspA94-PdT empregando protocolo 1.

Figura 68 - Cultivo de E. coli BL21 (DE3) para produção de PspA94-RL-PdT em meio LB-can.

Figura 69 - Purificação de PspA94-RL-PdT empregando o protocolo 1. 144

Figura 70 - Concentração de IgG no soro dos camundongos 14 dias após 1a imunização

Figura 71 - Concentração de IgG no soro dos camundongos 14 dias após 2a imunização

Figura 72 - Concentração de IgG no soro dos animais 14 dias após 3a imunização.

Figura 73 - Concentração de IgG no soro dos camundongos após 3a imunização: comparação entre as proteínas híbridas

Figura 74 - Variação da concentração média de lgG no soro dos camundongos após cada imunização.

Figura 75 - Comparação da concentração máxima de lgG obtida após imunização com as proteínas híbridas PspA94-PdT e PspA94-RL-PdT apresentando diferentes graus de pureza. 150

Figura 76 - Sobrevivência após desafio letal intranasal, 151

Figura 77 - Inibição da atividade hemolítica de Ply pelo soro dos animais imunizados com os híbridos PspA94-PdT e PspA94-RL-PdT em relação ao grupo controle, que recebeu salina e adjuvante 152

Figura 78 - Comparação entre a inibição da atividade hemolítica pelos soros dos animais imunizados com os diferentes híbridos 



\section{LISTA DE TABELAS}

Tabela 1 - Algumas proteínas candidatas a compor novas vacinas pneumocócicas proteicas. Continua.

Tabela 2 - Relação entre presença de His/Trp na superfície da proteína e íons metálicos que oferecem adsorção.

Tabela 3 - Primers desenhados para construção dos híbridos com espaçadores 65

Tabela 4 - Composição meio Luria Bertani (LB) 68

Tabela 5. Concentrações de antibióticos utilizados no meio com cada construção. 69

Tabela 6 - Composição do meio quimicamente definido 72

Tabela 7 - Processo de purificação 01 PspA94-PdT 89

Tabela 8 - Processo de purificação 02 PspA94-PdT 92

Tabela 9 - Processo de purificação 03 PspA94-PdT 97

Tabela 10 - Processo de purificação 04 PspA94-PdT utilizando IMAC carregada com íons $\mathrm{Ni}^{2+}$

Tabela 11 - Processo de purificação 04 PspA94-PdT utilizando IMAC carregada com íons $\mathrm{Co}^{2+}$ 103

Tabela 12 - Fragmentos esperados nas digestões do plasmídeo pGEM-T/pspA94-FL-pdT de acordo com o mapa de restrição

Tabela 13 - Fragmentos esperados nas digestões do plasmídeo pGEM-T/pspA94-RL-pdT de acordo com o mapa de restrição

Tabela 14 - Processo de purificação 01 da PspA94-RL-PdT 135

Tabela 15 - Antígenos utilizados nos ensaios de imunização de camundongos 145 



\section{LISTA DE EQUAÇÕES}

Equação 1 - Velocidade máxima específica de crescimento celular............................... 71

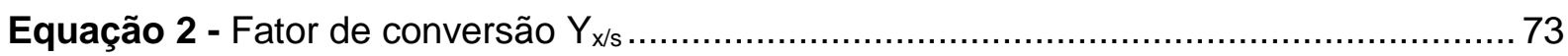



2 REVISÃo BIBLIOGRÁFICA

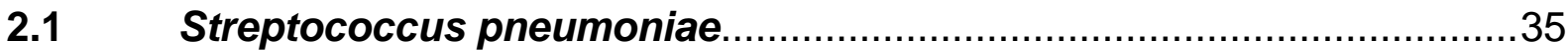

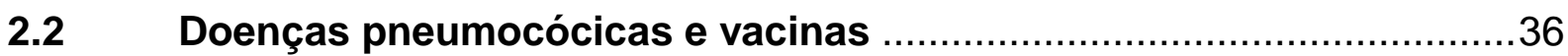

2.3 Proteína A de superfície de pneumococo ..........................................40

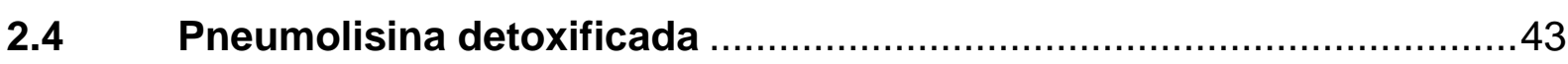

2.5 Sistemas de clonagem e expressão de proteínas recombinantes em Escherichia coli

2.6 Cultivo de Escherichia coli para obtenção de proteínas recombinantes. 48

2.7 Purificação de produtos biotecnológicos ..............................................49

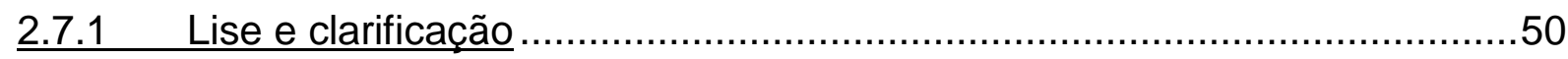

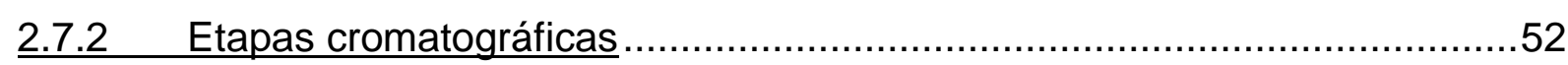

$2.8 \quad$ Estabilidade de proteínas recombinantes .......................................56

2.9 Moléculas híbridas e espaçadores moleculares.................................58

3 OBJETIVOS

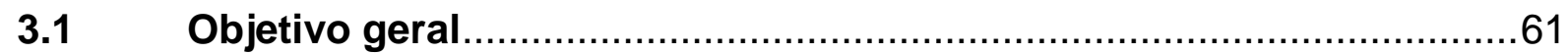

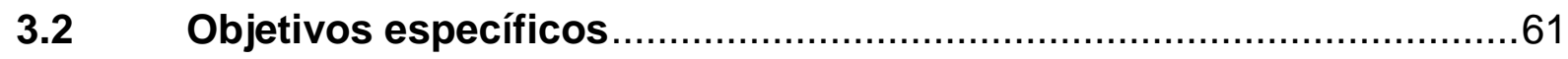

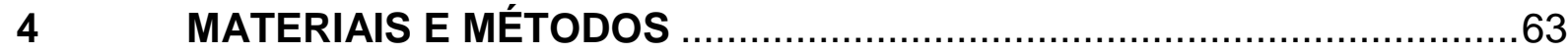

4.1 Estratégia para obtenção dos híbridos PspA94-PdT com espaçadores

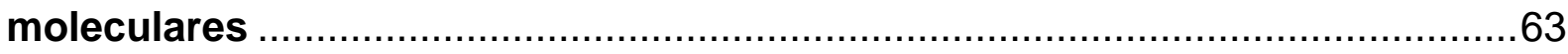

4.2 Obtenção dos genes de PspA94 e PdT unidos por espaçadores ........64

4.3 Clonagem dos genes dos híbridos com espaçadores .........................66

4.4 Avaliação da síntese das proteínas com espaçadores e da estabilidade dos clones. .68

4.5 Determinação da correlação entre densidade óptica e massa seca...69

4.6 Determinação do valor da velocidade específica máxima de

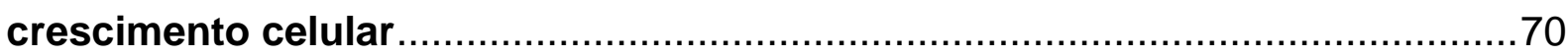

4.7 Cultivos para produção dos híbridos com espaçadores ......................71 
4.8 Purificação das proteínas híbridas com e sem espaçador .................. 73

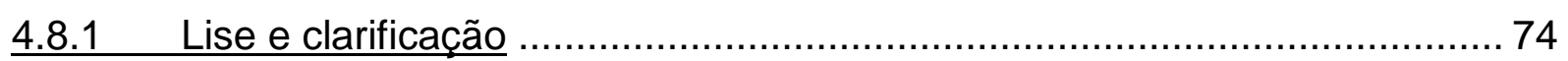

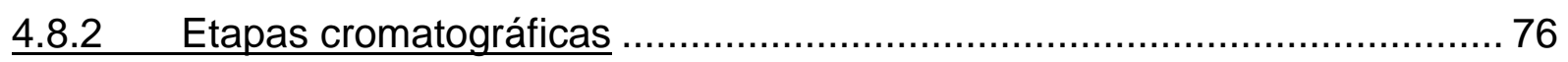

4.8.2.1 Cromatografia de troca aniônica ........................................................ 77

4.8.2.2 Cromatografia de afinidade por metal ................................................ 78

4.8.2.3 Cromatografia de interação hidrofóbica ............................................... 78

4.8.2.4 Cromatografia de exclusão molecular...................................................... 78

4.8.3 Análise dos processos de purificação ................................................... 79

4.9 Avaliação da integridade das proteínas híbridas ……….................... 79

4.10 Análise da influência de estabilizantes na integridade do híbrido ...... 80

4.11 Ensaios para deteç̧ão de atividade proteolítica ................................ 81

4.12 Sequenciamento da porção N-terminal........................................... 82

4.13 Ensaios de avaliação de resposta imunológica dos híbridos PspA94-

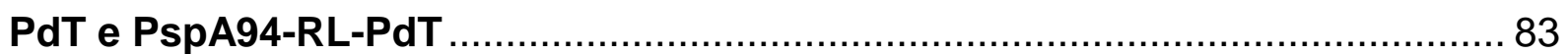

4.14 Avaliação da capacidade de inibição da atividade hemolítica de Ply pelo soro dos animais imunizados com os híbridos ................................................. 84

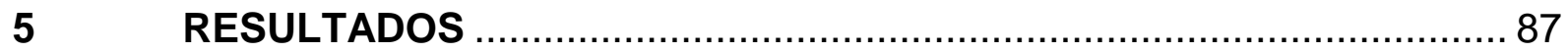

5.1 Híbrido sem espaçador PspA94-PdT ……....................................... 87

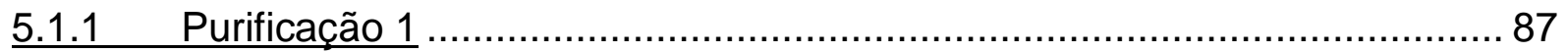

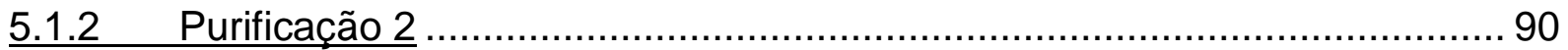

5.1.2.1 Ensaio de digestão de caseína ........................................................... 93

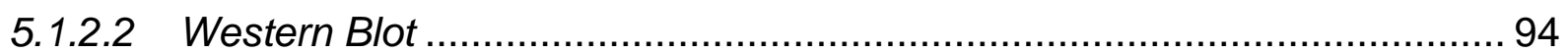

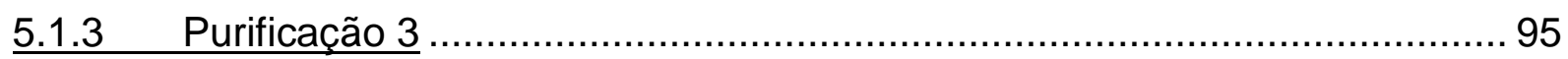

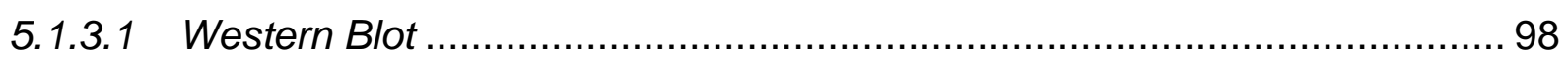

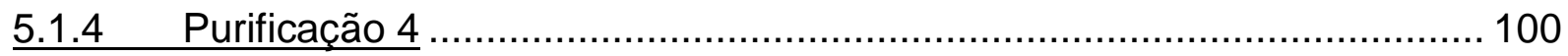

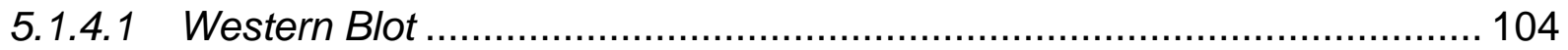

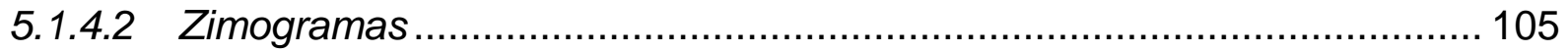

5.1.5 Ensaios específicos para a detecção de serinoproteases e de

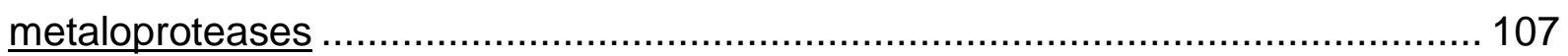

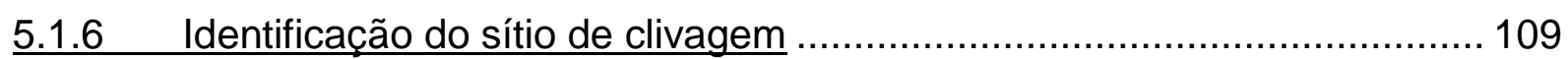

5.2 Híbrido com espaçador flexível: PspA94-FL-PdT ............................ 112

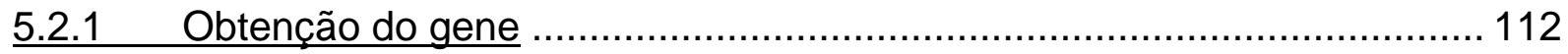

5.2.2 Testes de expressão em E. coli BL21 Star (DE3)pLysS ......................... 116 
5.2.3 Testes de expressão em E. coli Rosetta (DE3) …………....................119

5.3 Híbrido com espaçador rígido: PspA94-RL-PdT .............................121

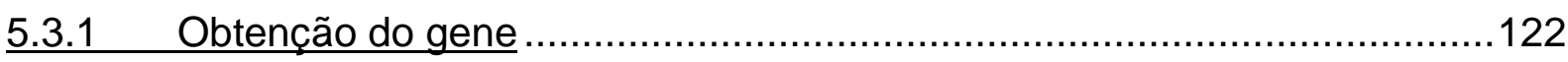

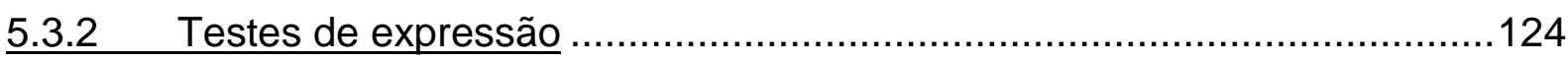

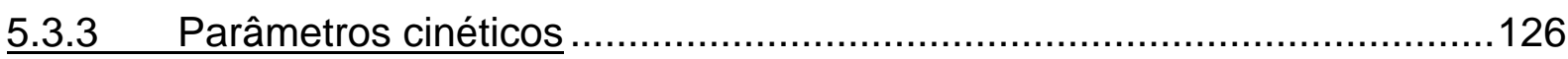

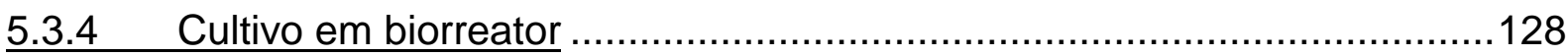

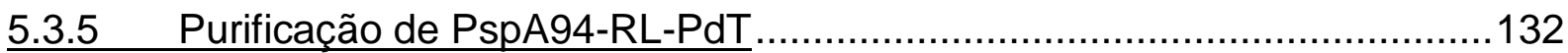

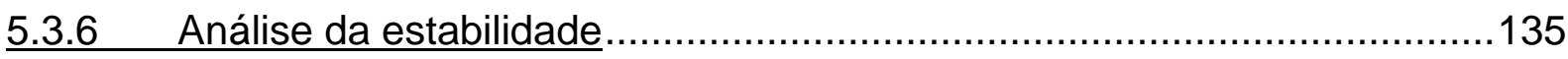

5.3.7 Avaliação da influência de estabilizantes no armazenamento do híbrido

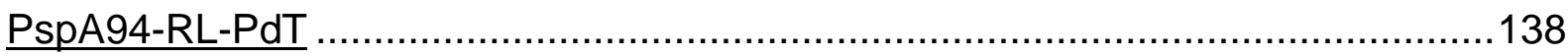

5.4 Ensaios para avaliação da resposta imunológica dos híbridos com e sem espaçador molecular entre os antígenos ................................................140

5.4.1 Produção e purificação dos antígenos ………..................................141

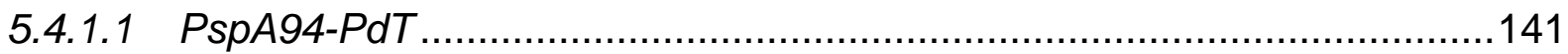

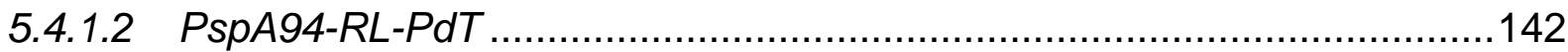

5.4.2 Produção de anticorpos e desafio intranasal........................................144

5.4.3 Inibição da atividade hemolítica de Ply pelo soro dos animais imunizados

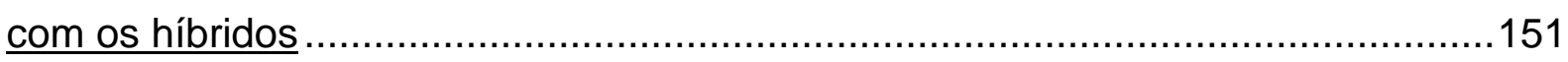

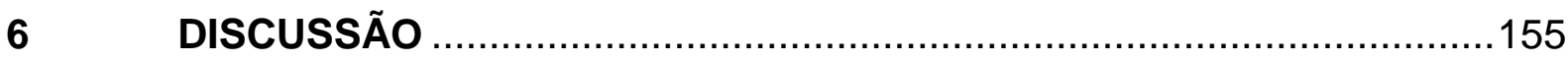

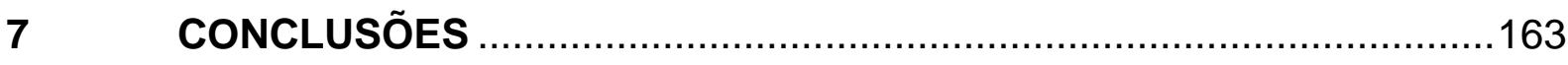

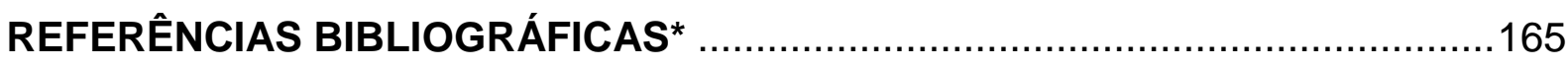

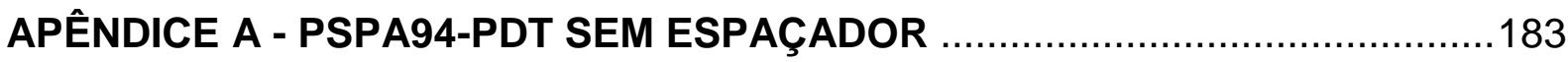

APÊNDICE B - PSPA94-PDT COM ESPAÇADOR FLEXÍVEL .............................185

APÊNDICE C -PSPA94-PDT COM ESPAÇADOR RÍGIDO …...........................187 



\section{INTRODUÇÃO}

Streptococcus pneumoniae tem sido considerado por anos uma das principais causas de doenças invasivas sérias como pneumonia bacteriana, sepse, meningite e otite aguda em crianças (Vieira et al., 2007; Van Der Poll e Opal, 2009; Balsells et al., 2017; Van Dyke et al., 2017).

A colonização da nasofaringe por S. pneumoniae é bastante comum e é provável que todos os humanos já tenham sido colonizados por este patógeno ao menos uma vez nos primeiros anos de vida (Bogaert et al., 2004). Quando esse microrganismo invade outros nichos, tem início a doença pneumocócica. As doenças pneumocócicas podem ser menos graves, chamadas não invasivas, como sinusite, otite e pneumonia (em inglês conhecida como community acquired pneumonia, CAP); ou mais graves, chamadas de invasivas, como bacteremia, pneumonia necrosante, meningite e sepse.

A Organização Mundial da Saúde estima que, em 2008, das cerca de 8,8 milhões de mortes anuais globais entre crianças menores que 5 anos, 476.000 foram causadas por infecções pneumocócicas. Nos países em desenvolvimento as taxas de letalidade entre as crianças mais jovens podem chegar a $20 \%$ para sepse pneumocócica (World Health Organization, 2012). O'brien et al. (2009) estimou em outro estudo, em 2009, que esse microorganismo era responsável por $11 \%$ das mortes de crianças menores que 5 anos no mundo.

O tratamento de infecções pneumocócicas apresenta dificuldades devido ao aparecimento, em todo o mundo, de sorotipos de pneumococos resistentes à penicilina, azitromicina e outros antibióticos (Barocchi et al., 2007; Dagan e Klugman, 2008; Greenberg et al., 2008; Song, J. H. et al., 2012), principalmente onde a vacinação não é rotina (Lixandru et al., 2017). Por isso, a vacinação é reconhecida como a melhor maneira de combater essas patologias. A administração de vacinas tem demonstrado boa eficácia na prevenção da infecção pneumocócica, desde que a composição agregue os sorotipos prevalentes em cada região geográfica no momento da vacinação.

S. pneumoniae é uma bactéria Gram-positiva que possui, como estrutura externa, uma cápsula polissacarídica que constitui o seu principal fator de virulência. 
A cápsula tem a propriedade de estimular a produção de anticorpos em indivíduos imunocompetentes, anticorpos esses que são utilizados para classificar os pneumococos em sorotipos (Henrichsen, 1995). Uma revisão recente elenca 97 sorotipos distintos (Geno et al., 2015), que são reconhecidos com base nas diferenças químicas e antigênicas dos polissacarídeos capsulares (PS), cuja distribuição difere por faixa etária, sintomatologia clínica e região geográfica (Hausdorff et al., 2000).

Todas as vacinas pneumocócicas atualmente em uso têm como base o PS capsular livre ou conjugado a uma proteína. Em ambos os casos, os sorotipos presentes nas primeiras formulações vacinais compreendiam apenas os considerados de maior relevância epidemiológica na distribuição da doença pneumocócica nas regiões onde a vacina foi formulada. Apesar de novos sorotipos prevalentes na Ásia e América Latina terem sido adicionados nas novas formulações a fim de ganhar o mercado mundial, os problemas quanto à limitação de sorotipos ainda persistem. Cada cápsula de sorotipo diferente que compõe a formulação dessas vacinas é produzida em um processo independente, o que limita a composição da vacina, e, portanto, sua cobertura, além de acarretar um alto custo por dose e também levar à substituição dos sorotipos prevalentes na população por outros não presentes na formulação das vacinas (Weinberger et al., 2009; Weinberger et al., 2011; Feikin et al., 2013; Balsells et al., 2017).

Uma alternativa para aumentar a cobertura da vacina e, ao mesmo tempo, reduzir o custo, é obter uma vacina que utilize proteínas imunogênicas do pneumococo. Essa vacina, ao contrário da vacina baseada em polissacarídeo capsular, teria uma resposta T-dependente, tornando possível seu uso em crianças menores de 2 anos de idade e ofereceria proteção independente do sorotipo, evitando assim a pressão seletiva da vacinação que tem levado à mudança dos sorotipos prevalentes na população.

Entre as proteínas candidatas, a proteína A de superfície do pneumococo (PspA) e a pneumolisina geneticamente detoxificada (PdT) mostraram resultados promissores em modelos de sepse e a combinação destas duas proteínas geneticamente fusionadas em uma molécula híbrida apresentou maior deposição de complemento e indução de fagocitose do que a simples mistura dos antígenos, além de oferecer proteção contra desafio sistêmico em camundongos (Goulart et al., 2013). 
As proteínas de fusão são uma nova classe de biomoléculas formadas por duas ou mais proteínas ou fragmentos de proteinas que podem estar ou não unidas por espaçadores moleculares. Estudos mostraram que a junção de duas proteínas distintas em uma molécula pode levar a um aumento da atividade enzimática ou antigênica de cada uma delas ou ainda a uma atividade sinérgica de ambas (Zhao et al., 2008; Lu et al., 2009; Lee et al., 2013), além de permitir a produção de mais de um antígeno em um único processo produtivo.

Diante do exposto, para continuarmos avançando no desenvolvimento de uma nova vacina proteica, mais barata e com cobertura independente do sorotipo, uma construção capaz de produzir a proteína híbrida PspA94-PdT em cultivos de E. coli de alta densidade está sendo desenvolvida. A produção desta proteína híbrida deverá gerar uma vacina mais promissora, tanto do ponto de vista econômico quanto do ponto de vista de ampliação de cobertura, do que as vacinas de PS livres e as de PS conjugadas a proteínas carreadoras não relacionadas ao pneumococo. 


\section{REVISÃO BIBLIOGRÁFICA}

Os tópicos a seguir apresentam a revisão bibliográfica dos assuntos relacionados a este trabalho.

\section{$2.1 \quad$ Streptococcus pneumoniae}

Streptococcus pneumoniae é uma bactéria pertencente à família Streptococcaceae que é comumente encontrada na mucosa da nasofaringe e orofaringe de seres humanos sadios.

S. pneumoniae está presente na microbiota comensal do trato respiratório superior. A colonização da nasofaringe é normalmente assintomática e funciona como um evento de imunização natural (Dommaschk et al., 2017). O estudo de De Lencastre et al. (1999), realizado quando ainda não haviam sido introduzidas vacinas conjugadas na prevenção da doença, mostrou que 40 a 70\% das pessoas possuíam a sua nasofaringe colonizada por esta bactéria.

A colonização com pneumococo é reconhecida como a primeira etapa do desenvolvimento da doença. Embora seja comumente assintomática, ela pode progredir a doenças respiratórias e sistêmicas. As infecções pneumocócicas variam consideravelmente quanto à severidade e delas pode decorrer uma enorme gama de complicações clínicas (Marrie et al., 2017), sendo que sobreviventes da doença invasiva podem carregar algumas sequelas em longo prazo, como: perda da audição e deficiências neurológicas (De Lencastre et al., 1999; Bogaert et al., 2004).

S. pneumoniae é uma bactéria Gram-positiva e anaeróbia aerotolorante, pertencente ao grupo das bactérias láticas e se apresenta na forma de diplococos lanceolados ou em cadeias. Possui, como estrutura externa, uma cápsula polissacarídica que constitui o principal fator de virulência, uma vez que é capaz de inibir a fagocitose e cepas sem cápsula não causam doenças. Outra propriedade da cápsula é estimular a produção de anticorpos em indivíduos imunocompetentes. Com base nesses anticorpos produzidos, os pneumococos são classificados em sorotipos (Henrichsen, 1995). Sabe-se que cada sorotipo corresponde a uma estrutura química diferente do polissacarídeo (PS) da cápsula e que cada um deles inibe a fagocitose 
com maior ou menor intensidade, o que resulta em uma habilidade diferenciada de cada sorotipo para causar a doença pneumocócica (Henrichsen, 1995). A Figura 1 apresenta o microorganismo, com destaque para sua cápsula polissacarídica. Atualmente, são reconhecidos 97 sorotipos com base nas diferenças químicas e antigênicas dos polissacarídeos capsulares (Geno et al., 2015). A distribuição desses sorotipos varia por faixa etária, sintomatologia clínica e região geográfica (Hausdorff et al., 2000).

Figura 1 - Streptococcus pneumoniae. A. Bactérias em cadeia curta vistas por microscopia eletrônica de varredura, barra $=1 \mu \mathrm{m}$, B. Diplococo visto por microscopia eletrônica de transmissão, barra $=0,5 \mu \mathrm{m}$. $O$ asterisco indica a cápsula polisacarídica.
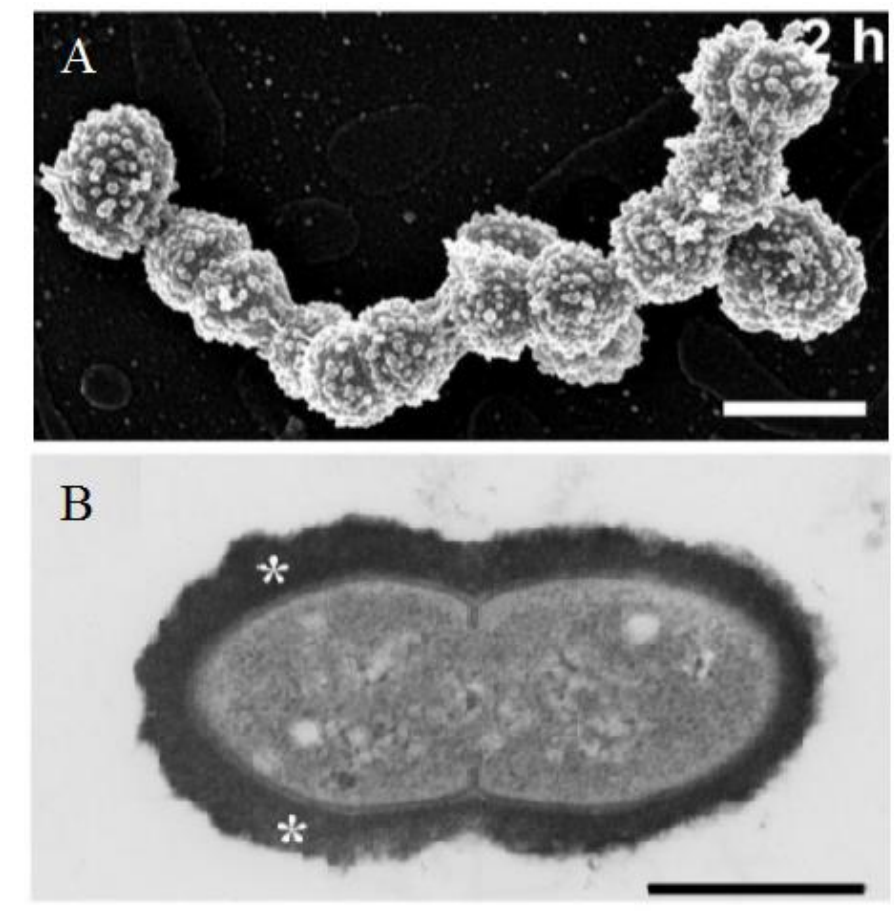

Fonte: Adaptado de Hammerschmidt et al. (2005).

\subsection{Doenças pneumocócicas e vacinas}

As doenças pneumocócicas podem ser divididas em doenças menos graves, como sinusite, otite e pneumonia não invasiva; e mais graves, ou invasivas, como bacteremia, pneumonia necrosante, meningite e sepse. 
A doença pneumocócica é precedida por uma colonização assintomática, que é especialmente alta em crianças (Bogaert et al., 2004). É estimado que aproximadamente $5,5 \%$ de todas as mortes entre crianças menores de 5 anos em 2008 foram causadas por infecções pneumocócicas. As taxas de letalidade entre as crianças mais jovens podem chegar a $20 \%$ para sepse pneumocócica nos países em desenvolvimento (World Health Organization, 2012).

O tratamento com antibióticos não tem se mostrado totalmente eficaz e, nas últimas décadas, a resistência do pneumococo à penicilina e a outros antimicrobianos tem aumentado em vários países (Hortal et al., 2001; Mangtani et al., 2003; Ochoa et al., 2005; Dueger et al., 2008; Liñares et al., 2010; Organización Panamericana De La Salud, 2013). Existem apenas alguns sorotipos de pneumococo que apresentam resistência aos antibióticos, porém são esses que estão tipicamente presentes na microbiota das crianças, que constitui um dos grupos de risco da doença, juntamente com idosos e imunocomprometidos (Fenoll et al., 1998; Ortqvist et al., 2005; Marrie et al., 2017). Por isso, a prevenção através da vacinação é considerada a estratégia mais indicada para diminuir as taxas de incidência e de mortalidade da doença (World Health Organization, 2012).

Atualmente, todas as vacinas pneumocócicas licenciadas para uso humano são baseadas na proteção oferecida pelo PS capsular livre ou conjugado a uma proteína. A primeira vacina pneumocócica constituída de PS livre foi produzida em 1977, e era composta de PS dos 14 sorotipos prevalentes na Europa e nos EUA. Esta foi substituída em 1983 por uma formulação 23-valente, utilizada até os dias atuais, apresentando cobertura de até $90 \%$ contra pneumonia em adultos jovens (Brandileone et al., 2003).

O PS é um antígeno timo-independente, e, por isso, produz baixa resposta imune em crianças, principalmente nas menores de dois anos, uma vez que não estimula a maturação clonal. A conjugação do PS com uma proteína carreadora transforma a resposta imune em T-dependente, tornando eficiente seu uso em crianças menores de 2 anos de idade.

A primeira vacina conjugada a ser registrada foi a PCV-7 ou Prevnar-7, em 2000 pela Wyeth - Pfizer, contendo em sua formulação polissacarídeos de 7 sorotipos de pneumococo conjugados a proteína CRM197, toxina mutada de difteria. Desde então 
já foram lançadas a PCV-10 ou Synflorix (GSK) - contendo 10 polissacarídeos conjugados às proteínas CRM197, toxóide tetânico e proteína D de $H$. influenzae - e a PCV-13 ou Prevnar-13, contendo os 13 polissacarídeos conjugados à proteína CRM197. Desde seu lançamento a PCV-13 tem substituído a PCV-7 em muitos países, que já não mais comercializam a PCV-7 (Poolman et al., 2013).

Devido à dificuldade técnica e ao custo, todas as vacinas conjugadas congregam um número limitado de PS (13 até o momento), levando a uma cobertura limitada e desencadeando uma pressão seletiva que faz com que ocorra a substituição dos sorotipos vacinais, antes prevalentes na população, por outros não incluídos na vacina (Frazão et al., 2005; Huang et al., 2005; Daniels et al., 2016). A PCV-10 foi incluída no calendário de vacinação nacional em 2010 e causou uma diminuição de 89\% nos casos de doença pneumocócica invasiva em crianças menores de 2 anos, apontada por (Dos Santos et al., 2013). Neste estudo Dos Santos não pode detectar aumento de casos de nenhum outro sorotipo. Um estudo mais recente já aponta o aumento da taxa de doenças pneumocócicas causadas por outros sorotipos, que não os presentes na formulação da PCV-10 (Medeiros et al., 2017).

O desenvolvimento de vacinas que utilizem proteínas imunogênicas e conservadas do pneumococo é uma alternativa para aumentar a cobertura da vacina e reduzir custos, uma vez que proteínas oferecem resposta imune T-dependente e resultariam em proteção independente de sorotipo. Diversas proteínas têm sido avaliadas para compor novas vacinas pneumocócicas. Algumas delas estão apresentadas na Tabela 1.

Uma vez que estudos vêm demonstrando que mais de uma proteína seria necessária para compor essa nova vacina, este trabalho propõe a clonagem e produção de duas proteínas de pneumococo em uma molécula híbrida, a qual poderá ser obtida a partir de um único processo. 


\begin{tabular}{|c|c|}
\hline $\begin{array}{l}\text { Proteína } \\
\text { candidata }\end{array}$ & Descrição \\
\hline PspA & $\begin{array}{l}\text { A proteína A de superfície do pneumococo é uma proteína que se liga à } \\
\text { colina da parede da bactéria e interfere na ação do complemento do } \\
\text { sistema imune do hospedeiro. PspA é relativamente conservada entre os } \\
\text { isolados de pneumococos e algumas variantes oferecem proteção cruzada } \\
\text { contra cepas carregando diferentes variantes de PspA. }\end{array}$ \\
\hline PspC & $\begin{array}{l}\text { É uma proteína multifuncional capaz de interagir com o complemento } \\
\text { através de ligação com o C3 e com o Fator H. Também funciona como } \\
\text { molécula de adesão através da interação com slgA. A PspC apresenta } \\
\text { heterogeneidade entre os isolados de pneumococo, mas há ampla } \\
\text { reatividade cruzada dos anticorpos induzidos contra uma única variante de } \\
\text { PspC. }\end{array}$ \\
\hline PotD & $\begin{array}{l}\text { É uma proteína de superfície que se liga a poliamina, mediando a entrada } \\
\text { desta molécula na célula bacteriana. Imunização subcutânea com PotD } \\
\text { recombinante foi capaz de proteger camundongos em desafio de morte. }\end{array}$ \\
\hline PhtD & $\begin{array}{l}\text { É uma proteína de superfície envolvida no processo de invasão do } \\
\text { pneumococo e inibição da deposição de complemento. Ela é altamente } \\
\text { conservada entre isolados de pneumococo e estudos mostraram que ela } \\
\text { provoca resposta imune protetora em vários modelos animais em ensaios } \\
\text { pré-clínicos incluindo doença invasiva e pneumonia. }\end{array}$ \\
\hline PsaA & $\begin{array}{l}\text { O antígeno A de superfície do pneumococo é uma lipoproteína conservada, } \\
\text { presente em todos os isolados de pneumococo e é um importante fator de } \\
\text { virulência. Imunização sistêmica com PsaA recombinante induziu pouca ou } \\
\text { nenhuma proteção em desafios de morte, porém sua eficácia na proteção } \\
\text { contra colonização de } S \text {. pneumoniae foi demonstrada em estudos usando } \\
\text { adjuvantes de mucosa e em coadministração com PCV7. }\end{array}$ \\
\hline
\end{tabular}

Tabela 1 - Algumas proteínas candidatas a compor novas vacinas pneumocócicas proteicas. Continua.

Fonte: Adaptado de Ginsburg et al. (2012); Darrieux et al. (2013 e Miyaji et al. (2013). 


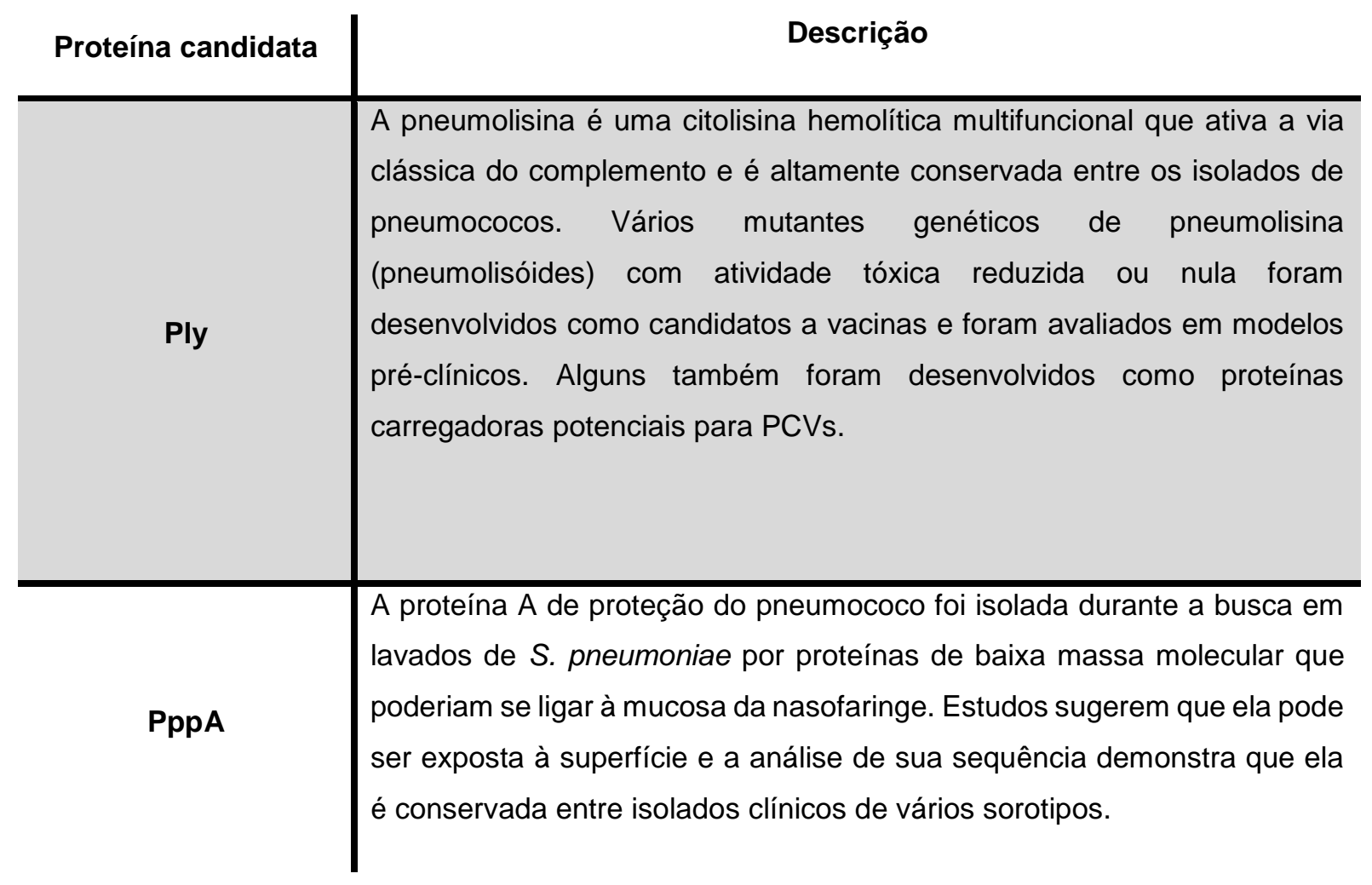

Tabela 1 - Algumas proteínas candidatas a compor novas vacinas pneumocócicas proteicas. Conclusão

Fonte: Adaptado de Ginsburg et al. (2012); Darrieux et al. (2013) e Miyaji et al. (2013).

Dentre as proteínas candidatas a compor uma nova vacina, a proteína $A$ de superfície do pneumococo (PspA) e a pneumolisina geneticamente detoxificada (PdT) vem sendo amplamente estudadas. Já foram obtidos resultados promissores destas duas moléculas combinadas em modelos de sepse e a combinação das duas proteínas geneticamente fusionadas em uma molécula híbrida ofereceu proteção contra desafio sistêmico em camundongos e apresentou maior deposição de complemento e indução de fagocitose do que a simples mistura dos antígenos (Goulart et al., 2013).

\subsection{Proteína A de superfície de pneumococo}

A PspA é um importante fator de virulência do pneumococo, exposto na superfície da bactéria e expresso por todas as linhagens de $S$. pneumoniae 
caracterizadas até o momento. Esta proteína já mostrou resposta de proteção contra cepas virulentas de pneumococos em camundongos desafiados com 0 correspondente a 100 vezes a dose letal (Briles et al., 1998).

A PspA é um antígeno promissor para uso em vacinas proteicas pneumocócicas principalmente devido ao fato de ela ser uma proteína exposta que se projeta para além da capsula polissacarídica. A PspA possui um domínio de ligação à colina, e além disso interfere na ação do complemento, de forma a bloquear a via alternativa pela redução da quantidade de $\mathrm{C} 3 \mathrm{~b}$, reduzindo assim a capacidade do hospedeiro de eliminar a bactéria (Beall et al., 2000).

A PspA apresenta também capacidade de se ligar à apolactoferrina humana, uma glicoproteína da família da ferritina que faz parte do sistema imune inato, impedindo sua ação bacteriostática e bactericida (Shaper et al., 2004; Senkovich et al., 2007).

A estrutura da PspA (Figura 2) é composta por quatro domínios (Jedrzejas et al., 2001; Moreno et al., 2010):

a) a porção $\mathrm{N}$-terminal, que é carregada eletricamente, é a porção que se encontra exposta para fora da bactéria. Apresenta $\alpha$-hélice como estrutura secundária predominante e é nela que se encontra a região conhecida como clade definition region, ou CDR. A classificação das proteínas PspA é baseada na identidade e no alinhamento das sequências de aminoácidos dessa região definidora de clado;

b) domínio rico em prolinas, de comprimento variável, que pode conter trechos sem prolina intercalados;

c) domínio com 10 repetições de uma sequência de 20 aminoácidos, que é responsável por ancorar a proteína aos resíduos de colina encontrados nos ácidos teicóico e lipoteicóico da parede celular e

d) a porção C-terminal, que é composta por uma curta cauda hidrofóbica. 
Figura 2 - Esquema da estrutra da PspA. A molécula de PspA possui a região N-terminal rica em a-hélice ( $A$ e $B$ ) que contém a região CDR (definidora de clado), a região rica em prolina (C) e o domínio de ligação à colina.

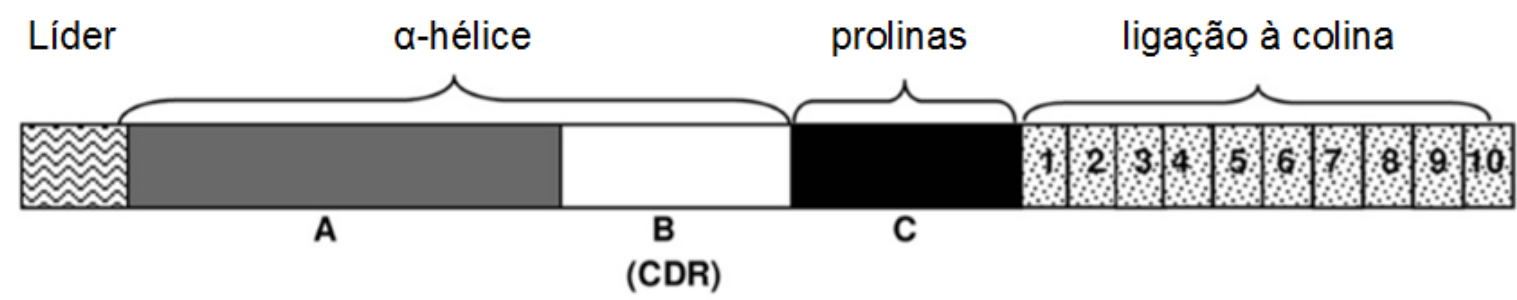

Fonte: Adaptado de (Moreno et al., 2010)

Normalmente, os fragmentos do gene da PspA inseridos em vetores para expressão heteróloga não possuem a informação da proteína inteira. Esses fragmentos não possuem a região de ligação à colina presente na proteína originalmente. Isso pode ser feito porque essa região fica ancorada na parede celular do $S$. pneumoniae e não está exposta na superfície do microrganismo, ou seja, ela não está acessível ao reconhecimento pelos anticorpos, não sendo então necessária para o desenvolvimento da resposta imune (Yother et al., 1998).

Com base na sequência de aminoácidos foram observadas 3 famílias distintas de PspA, divididas em 6 grupos ou clados. A família 1 é constituída de dois clados (1 e 2); a família 2 constituída de três clados (3, 4 e 5) e a família 3 de apenas um clado (6). A grande maioria dos $S$. pneumoniae isolados de pacientes são classificados como pertencentes às famílias 1 e 2, responsáveis por aproximadamente $90 \%$ dos casos de doenças (Briles, Hollingshead, King, et al., 2000). Estudos realizados no Brasil e Colômbia indicam resultados similares, com a prevalência de linhagens com PspAs das famílias 1 e 2 em respectivamente 94 e 97,5\% dos isolados clínicos (Vela Coral et al., 2001; Brandileone et al., 2004).

As famílias de PspA apresentam graus variáveis de reatividade cruzada entre si (Nabors et al., 2000). Estudos mostram que PspA de famílias diferentes induzem anticorpos com capacidades distintas de reconhecimento de moléculas heterólogas (Darrieux et al., 2008; Moreno et al., 2010). Essa variabilidade no reconhecimento também ocorre com proteínas do mesmo clado. Desta forma, uma série de estudos do Centro de Biotecnologia do Instituto Butantan buscaram identificar PspAs que 
oferecem ampla reatividade cruzada entre os clados (Darrieux et al., 2008; Ferreira et al., 2010; Moreno et al., 2010; Goulart et al., 2011). Um desses estudos identificou dois fragmentos recombinantes capazes de induzir anticorpos com ampla reatividade cruzada dentro da família 1: PspA245 e PspA94, sendo esta última objeto deste trabalho (Goulart et al., 2011).

A PspA já foi utilizada com sucesso em ensaios clínicos de fase 1 (Briles, Hollingshead, Brooks-Walter, et al., 2000; Nabors et al., 2000). A imunização intramuscular de voluntários humanos com PspA usando hidróxido de alumínio como adjuvante induziu a produção de $\lg G$ anti-PspA e o soro dos indivíduos imunizados protegeu camundongos desafiados com pneumococo de diferentes sorotipos (Briles, Hollingshead, King, et al., 2000).

\subsection{Pneumolisina detoxificada}

A pneumolisina é uma toxina que pertence à família de citolisinas dependentes de colesterol, que são produzidas por algumas bactérias Gram-positivas, é também um importante fator de virulência e está presente em todos os isolados clínicos de $S$. pneumoniae. Ela possui $53 \mathrm{kDa}$, superfície altamente eletronegativa e a estrutura com as cargas eletrostáticas de sua superfície está apresentada na Figura 3 (Hirst et al., 2004). Diferentemente da PspA, Ply é bastante conservada entre as cepas de pneumococo, com apenas 3,3\% de variação na sequência (Jefferies et al., 2007).

A pneumolisina foi recentemente apontada como peça chave na transmissão do pneumococo: além de estar relacionada a uma resposta inflamatória e, consequentemente, presente em secreções, sua atividade in vivo também auxilia na sobrevivência do pneumococo fora do hospedeiro. Linhagens de pneumococo cuja pneumolisina é deficiente em atividade hemolítica escapam da vigilância da resposta imune inata, porém a um custo de uma menor taxa de transmissão (Zafar et al., 2017). 
Figura 3 - Estrutura da pneumolisina. a) Representação em fitas. b) Representação eletrostática da superfície de Ply. As duas regiões eletronegativamente significativas estão indicadas por A e B. Vermelho indica potencial eletronegativo e azul indica potencial positivo.
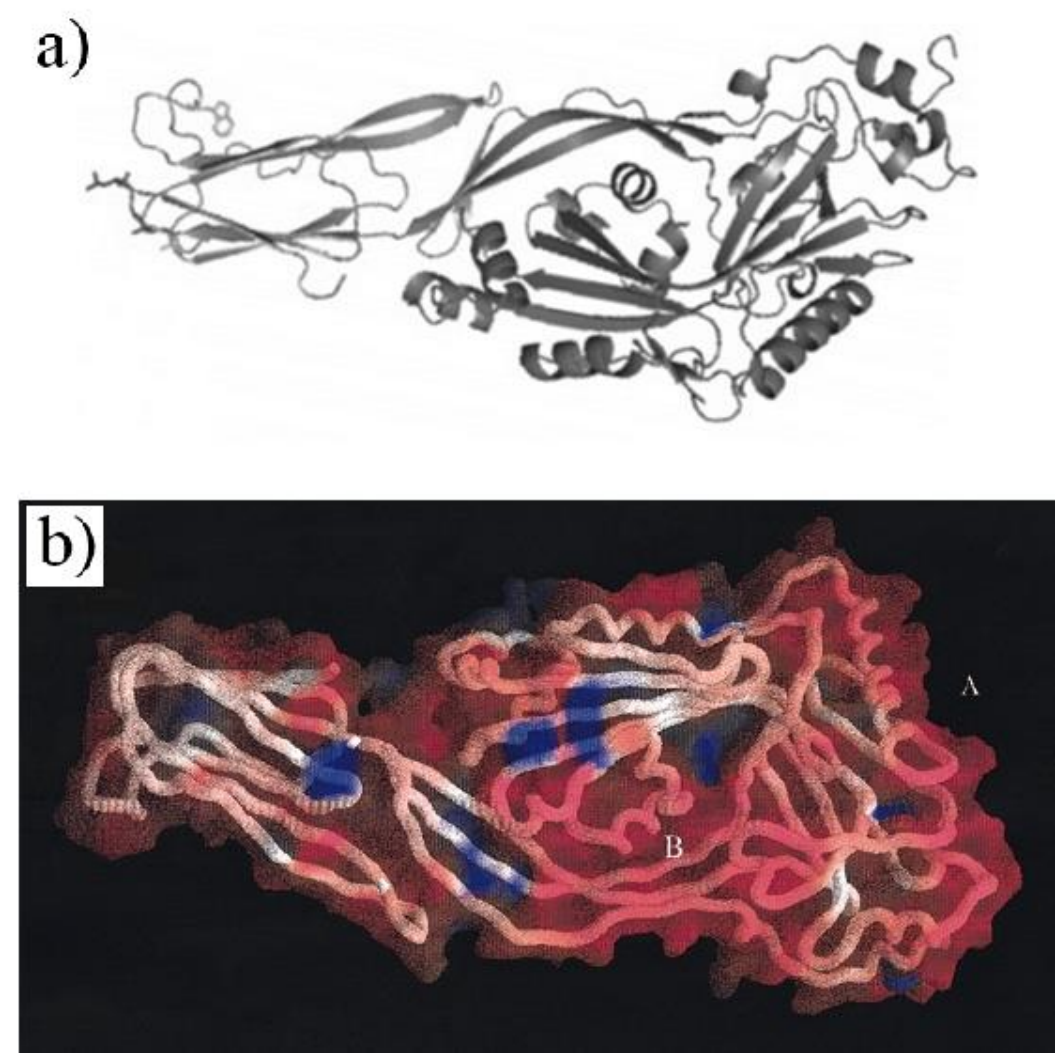

Fonte: a) Adaptado de Taylor et al. (2013); b) Adaptado de Rossjohn et al. (1998).

A Ply é uma toxina que possui várias outras funções biológicas importantes, tais como: ela é capaz de se ligar a TLR4 (Malley et al., 2003), inibe a resposta inflamatória de células polimorfonucleares (Paton e Ferrante, 1983) e provoca a apoptose das células do trato respiratório (Srivastava et al., 2005). Mais recentemente foi estabelecido que a formação de poros por Ply ativa o inflamassoma NLRP3 (Littmann et al., 2009; Mcneela et al., 2010) e que somente a proteína inteira é capaz de induzir a atividade hemolítica, já que pneumolisinas truncadas não foram capazes de ativar a produção de IL-1ß (Witzenrath et al., 2011). O conjunto dessas propriedades faz de Ply não apenas uma excelente candidata a nova vacina pneumocócica proteica, mas 
também aponta para um potencial efeito imunomodulador, ou adjuvante, dessa molécula na vacina.

Ply apresenta elevada toxicidade celular, mas pode ser geneticamente alterada para perder suas propriedades tóxicas (detoxificada), e atuar como antígeno na vacina proteica. Assim, mutantes geneticamente detoxificados de pneumolisina (dPly) foram obtidos, entre eles o mutante conhecido como PdT, que contém 3 mutações: Asp$385 \rightarrow$ Asn, Cys-428 $\rightarrow$ Gly e Trp-433 $\rightarrow$ Phe. A substituição de cisteína por glicina na posição 428 e de triptofano por fenilalanina na posição 433 reduziram a atividade hemolítica (citotóxica) e a substituição de aspartato por asparagina reduziu a habilidade da toxina de se ligar a imunoglobulina $\mathrm{G}$ e aboliu a habilidade de ativar a via de complemento (Berry et al., 1995).

A segurança e imunogenicidade de uma vacina composta por pneumolisóides já foi testada em ensaios clínicos de fase 1 (Kamtchoua et al., 2013) e ensaios clínicos de fase 1 e 2, juntamente com a proteína PhtD (Leroux-Roels et al., 2014; Prymula et al., 2014). Além disso, alguns estudos relatam a imunização com híbridos de toxóides de pneumolisina com outras proteínas de pneumococo, evidenciando: a necessidade de mais de uma proteína para compor uma vacina com resposta imune suficiente, o caráter adjuvante de dPly e a vantagem de se produzir uma molécula híbrida de duas proteínas que são obtidas a partir de um único processo (Lu et al., 2009; Douce et al., 2010; Mann et al., 2014; Chen et al., 2015).

\subsection{Sistemas de clonagem e expressão de proteínas recombinantes em Escherichia coli}

Sistemas de clonagem e expressão de proteínas recombinantes em E. coli são amplamente utilizados devido à habilidade dessa bactéria para multiplicar-se rapidamente e alcançar altas densidades celulares em cultivos utilizando substratos comuns de baixo valor agregado, além de ser uma bactéria geneticamente bem caracterizada. Por ser a plataforma de expressão de proteínas mais popular, existem várias ferramentas moleculares e protocolos para produzir proteínas com diversas particularidades (Rosano e Ceccarelli, 2014). 
O gene que codifica a proteína de interesse deve ser inserido em um vetor de clonagem com a finalidade de amplificar a informação genética em centenas de cópias. Os vetores de clonagem mais comuns são os plasmídeos: elementos genéticos extra-cromossomais, geralmente são compostos de DNA dupla-fita circulares, com sua própria origem de replicação (ori), ou seja, se multiplicam independentemente dos cromossomos. A região ori regula a replicação do plasmídeo. Essa regulação é necessária para que o plasmídeo não sature a célula hospedeira com um número excessivo de cópias e para que ele não seja perdido se a replicação for mais lenta que o ciclo celular do organismo (Zaha et al., 2003; Madigan et al., 2010).

O gene de interesse é então transferido para um vetor de expressão, que deve priorizar não o maior número de cópias plasmidiais, mas a maior taxa de tradução da proteína de interesse, uma vez que o objetivo da indução da expressão gênica é a produção da proteína alvo (Jia e Jeon, 2016).

Um plasmídeo de expressão deve possuir as seguintes características:

a) Uma origem de replicação, que regula a quantidade de cópias por célula. Os vetores de expressão da série $\mathrm{pET}$, por exemplo, apresentam 15-20 cópias por célula (Novagen, 1999);

b) Um promotor para transcrição forte e regulável, que deverá manter baixo o nível de tradução até o momento da indução, para conseguir maior produtividade da proteína de interesse. A sequência promotora T7 é muito usada devido à sua afinidade elevada pela T7 RNA polimerase e elevado nível de expressão. 0 sistema repressor mais comum é o baseado no operon lac, que fica reprimido por Lacl e é induzido por lactose ou por seu análogo estrutural isopropil- $\beta$-Dtiogalactosídeo (IPTG) (Rosano e Ceccarelli, 2014);

c) Um marcador para seleção celular, que frequentemente é um gene que confere à célula resistência a um determinado antibiótico, como por exemplo, canamicina ou ampicilina;

d) Um sítio de ligação ao ribossomo, para tornar possível a iniciação da tradução, além de um start códon e um stop códon (que podem estar presentes no vetor ou no próprio inserto); 
e) Um sítio de múltipla clonagem, com diversos sítios de restrição distintos, para tornar possível a inserção do gene de interesse.

Células chamadas competentes são utilizadas para a transformação, ou seja, inserção do plasmídeo com o inserto através da membrana para dentro da célula hospedeira. Existem cepas com diferentes genótipos, algumas mais adequadas para transformação com vetor de clonagem, por exemplo E. coli DH5a, e outras mais adequadas para transformação com vetor de expressão.

Ao estudar as características da proteína recombinante que se deseja produzir em E. coli, é possível definir qual a cepa de expressão mais apropriada. Por exemplo, uma das cepas mais utilizadas é a BL21(DE3). A nomenclatura BL21 designa que esta linhagem é deficiente nas proteases Lon e Omp-T, o que colabora para a produção de proteínas não-tóxicas (Terpe, 2006). O profago גDE3 carrega o gene da T7 RNA polimerase sob controle do promotor lacUV5, IPTG ou lactose é utilizado para maximizar a indução da expressão gênica (Jia e Jeon, 2016).

Para proteínas tóxicas ao hospedeiro, a cepa recomendada é a BL21(DE3)pLysS. O plasmídeo pLysS produz a lisozima T7, que reduz o nível basal de expressão do gene de interesse, pois inibe a T7 RNA polimerase. Desse modo, não há escape de tradução antes do momento de indução. Essa linhagem foi utilizada com sucesso para produção de uma forma truncada de exotoxina de Pseudomonas (PE) aumentando o rendimento em relação à linhagem BL21(DE3) e facilitando a sua purificação (Joshi e Puri, 2005).

Já para a produção de proteínas não naturais ou eucarióticas sem modificações pós-traducionais em E. coli, é recomendado o uso da linhagem Rosetta. Essa linhagem é derivativa da BL21, modificada para aumentar a expressão de proteínas que contém códons raramente usados pela $E$. coli. Ela contém um plasmídeo com resistência a cloranfenicol que produz tRNA para os códons AUA, AGG, AGA, CUA, CCC e GGA. Um projeto chamado Swedish Human Protein Atlas, que existe desde 2003 e tem o objetivo de mapear todas as proteínas humanas, após tentativas de expressão de várias proteínas em linhagem BL21(DE3) a trocou pela Rosetta e conseguiu além de viabilizar a produção de proteínas que antes não fora possível com a linhagem BL21(DE3), também aumentar o rendimento e a pureza daquelas produzidas anteriormente nesta mesma linhagem (Tegel et al., 2010). 
As linhagens "Star", como por exemplo a BL21 Star (DE3)pLysS, contém uma mutação na Rnase $\mathrm{E}$, que reduz a degradação de RNA e com isso aumenta a expressão da proteína. Como a estabilidade do mRNA é melhorada, essa linhagem possui maior nível de expressão basal do que a regular e, por isso, não é indicada para expressão de genes tóxicos. Essa linhagem foi utilizada com sucesso para produzir globulina de ligação à tiroxina (TBG) recombinante como proteína de fusão com uma sequência N-terminal adicionada ao gene (Zhou et al., 2006).

A família "Origami" possui mutações na tireodoxina redutase e na glutationa redutase que facilitam a formação de pontes de dissulfeto no citoplasma e, consequentemente, permitem que a proteína adquira um arranjo mais apropriado, aumentando a sua solubilidade (Sørensen e Mortensen, 2005).

\subsection{Cultivo de Escherichia coli para obtenção de proteínas recombinantes}

Os cultivos em batelada de bactérias, inclusive E. coli, passam por diversas fases conhecidas: fase lag, de adaptação metabólica do microrganismo ao novo meio; fase de crescimento exponencial, onde a velocidade específica de crescimento $(\mu)$ é máxima; fase estacionária, onde a taxa de divisão celular é aproximadamente igual a taxa de morte; e a fase de morte, onde os nutrientes se esgotam e a taxa de morte supera a taxa de divisão celular (Shuler e Karg, 1992).

Os cultivos para expressão de genes heterólogos em frascos agitados, que seguem o regime de batelada, devem ser induzidos antes do final fase exponencial de crescimento, quando o substrato já se encontra escasso no meio de cultivo, para se alcançar uma maior produtividade da proteína alvo (Neubauer et al., 1992)

Os cultivos de E. coli em biorreatores, que alcançam altas densidades celulares, são largamente utilizados para produção de proteína recombinante. Nesses cultivos, deve-se ter o cuidado de evitar que ocorram problemas como: inibição do crescimento celular por acúmulo de subprodutos metabólicos, como por exemplo acetato, e inibição do crescimento por substrato, como por exemplo, glicose (Robbins e Taylor, 1989). 
Para evitar esses problemas, em biorreatores são comumente utilizados cultivos descontínuos alimentados. Os cultivos de E. coli recombinante geralmente são feitos em três fases (Carvalho, 2009):

a) Cultivo descontínuo ou batelada, até que a fonte de carbono inicialmente presente seja consumida ( $\mu=\mu$ máx);

b) Cultivo descontínuo alimentado, onde o substrato é alimentado de forma controlada para evitar o acúmulo de subprodutos metabólicos $(\mu<\mu$ máx);

c) Indução da expressão, para máxima produção da molécula alvo $(\mu<<\mu$ máx).

A alimentação de substrato pode ser realizada de diversas maneiras: alimentação constante, linear, exponencial ou através do controle de oxigênio dissolvido ou de $\mathrm{pH}$. Todas elas visam manter a concentração do substrato suficiente para o crescimento bacteriano e abaixo da concentração inibitória (Sato, 2001).

A indução da expressão também é decisiva na produtividade do cultivo. As condições ótimas para a indução devem ser estudadas, levando-se em consideração: o momento da indução, a concentração do agente indutor e a razão de indutor por células (Rosano e Ceccarelli, 2014). Conforme já comentado neste trabalho, em construções derivadas do operon lac se utiliza o Isopropil- $\beta$-D-tiogalactopiranosídeo (IPTG) ou a lactose como indutor (Neubauer et al., 1992; Jia e Jeon, 2016).

O uso do IPTG em processos de larga escala apresenta desvantagens por ser tóxico e ter um custo elevado. A lactose é uma alternativa, porém ela apresenta a desvantagem de ser consumida como substrato pela bactéria (Lee et al., 2001).

\subsection{Purificação de produtos biotecnológicos}

A produção de vacinas é realizada em cinco etapas fundamentais: a primeira é a produção do antígeno; a segunda é o isolamento ou liberação desse antígeno; seguido pela terceira etapa: de purificação propriamente dita; quarta etapa: adição de outros componentes, como adjuvantes ou estabilizantes e por fim a quinta etapa: embalagem (Vaccines Europe, 2017). 
O processo de purificação, ou "downstream processing", nada mais é que o processamento do produto do cultivo até obter-se o grau de pureza requerido para 0 seu uso, buscando-se minimizar perdas e custos. As estratégias para o desenvolvimento de processos de purificação baseiam-se nas diferenças entre as propriedades físico-químicas do produto de interesse e as das impurezas, diferenças como: localização (intra ou extracelular), massa molecular, carga elétrica, hidrofobicidade, solubilidade e afinidade por ligantes específicos (De Simone, 2008).

As etapas que compõem o processo de purificação devem ser facilmente amplificáveis para uma escala industrial, e devem ser baseadas em mais de uma propriedade do produto (Wheelwright, 1991; Asenjo e Andrews, 2009).

\subsubsection{Lise e clarificação}

As primeiras etapas da purificação de uma proteína intracelular, após a separação celular, são compostas de suspensão da biomassa em tampão de lise, homogeneização, centrifugação e filtração (De Simone, 2008).

O sistema de homogeneização contínua de alta pressão, esquematizado na Figura 4, tem vantagens frente a outros métodos de ruptura celular: é facilmente escalonável, não adiciona solventes orgânicos ou enzimas ao meio e não altera o pH do material. Porém, é necessário acoplar o sistema de lise a um sistema eficaz de refrigeração, já que o rompimento de células em alta pressão pode aumentar a temperatura da suspensão bacteriana (Figueiredo, 2014).

No homogeneizador de alta pressão, a suspensão passa de um canal estreito para uma câmara de maior volume, onde as células se chocam com o pistão, o que causa uma variação brusca na pressão e a ruptura da membrana celular.

Após a ruptura, os restos celulares podem ser removidos por centrifugação ou filtração. Uma vez que a mistura obtida, comumente chamada de homogenato, contém todas as proteínas solúveis presentes na célula, é importante garantir que a proteína de interesse não sofra a ação de proteases. Isso pode ser feito pela redução da temperatura e/ou pela adição de inibidores de protease. Além disso, o homogenato 
deve seguir rapidamente para as etapas seguintes de purificação para evitar degradação da proteína de interesse e crescimento microbiano (Figueiredo, 2014).

Figura 4 - Representação esquemática de um homogeneizador de alta pressão

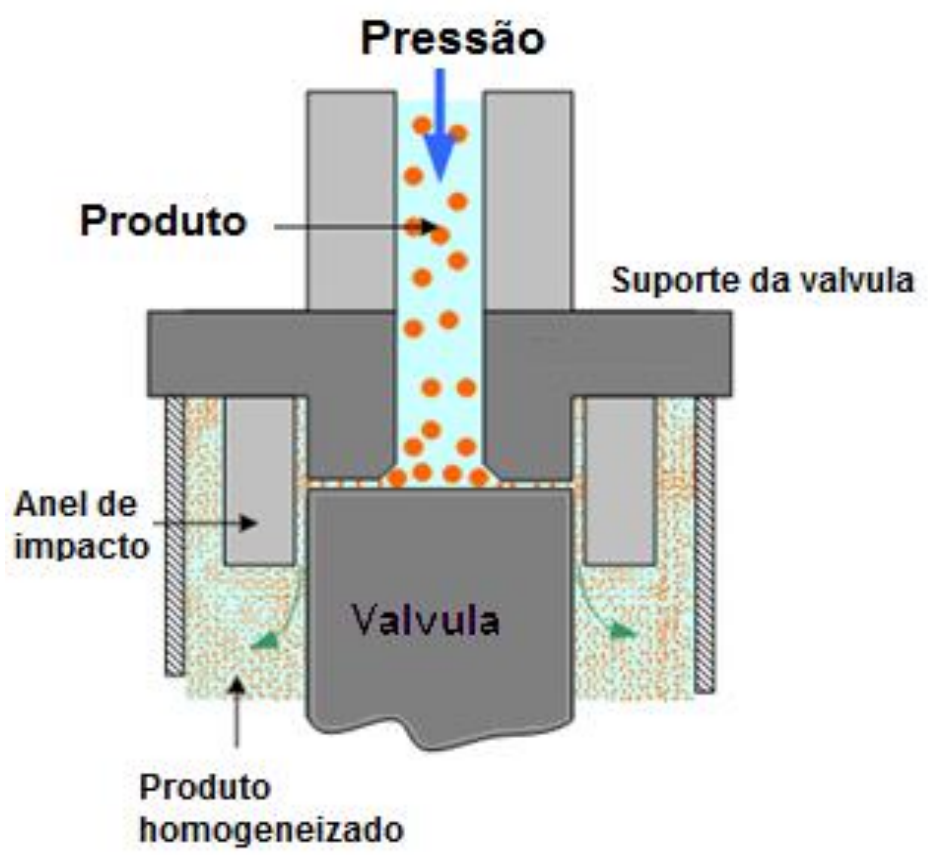

Fonte: Adaptado de Substech (2005).

Para a clarificação pode-se empregar também auxiliares de precipitação a fim de facilitar a separação do material insolúvel por meio da formação de agregados de maior tamanho. O detergente catiônico brometo de cetiltrimetilamonio (CTAB), por exemplo, é um agente bastante empregado na precipitação de substâncias poliméricas carregadas negativamente como ácidos nucleicos, polissacarídeos e lipopolissacarídeos (Lander et al., 2002), porém, até onde se sabe, não tem ampla aplicação na purificação de proteínas. Sua estrutura é apresentada na Figura 5 . Em nosso laboratório o uso do CTAB tem apresentado resultados promissores para eliminar impurezas na etapa de clarificação, levando ao aumento da pureza relativa de PspA4Pro (Figueiredo et al., 2017). O clarificado, após estas etapas, está adequado a passar por colunas cromatográficas. 
Figura 5 - Estrutura do detergente catiônico brometo de cetiltrimetilamonio (CTAB)

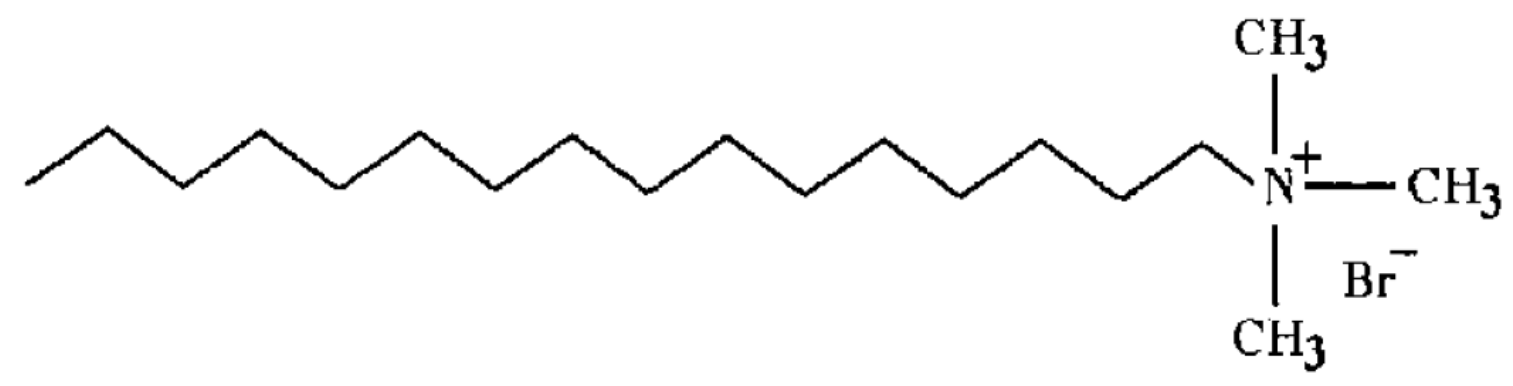

Fonte: Tomanee et al. (2004).

\subsubsection{Etapas cromatográficas}

A cromatografia em coluna é uma técnica usada para a separação de muitos compostos orgânicos. Essa técnica fundamenta-se basicamente na polaridade ou na afinidade relativa das moléculas envolvidas. Uma solução contendo o composto que se deseja purificar é aplicada na superfície superior da fase estacionária, e durante a eluição são coletadas frações com volume predeterminado, sendo que uma ou mais frações conterão o componente da mistura que se deseja separar. Existem vários tipos de resinas cromatográficas, cada uma com um princípio de separação (Asenjo e Andrews, 2009).

A cromatografia de troca iônica baseia-se na diferença de cargas elétricas entre as moléculas. Trocadores iônicos são preparados ligando-se covalentemente cátions ou ânions à matriz, que é um sólido essencialmente insolúvel de alta massa molecular. Esses íons ligados à matriz são associados com íons de cargas opostas, que podem ser trocados por outros íons de mesma carga. Assim, a resina de troca catiônica, por exemplo, tem íons negativos ligados à matriz e troca cátions. Durante a separação, os íons associados são trocados pelos íons de mesma carga presentes na amostra. ĺons diferentes possuem afinidades diferentes pelos íons fixos. As diferentes afinidades constituem a base da separação por troca iônica (Janson e Rydén, 1998).

A troca iônica é uma das técnicas mais largamente utilizadas na purificação industrial de proteínas e já foi empregada com sucesso como primeira etapa cromatográfica, ao invés da tradicional afinidade por metal, para purificação de PspA3 com cauda de 6 histidinas em nosso laboratório (Carvalho et al., 2012). As resinas de 
troca iônica são comumente utilizadas como etapas de purificação de anticorpos monoclonais, as catiônicas no modo bind-elute e as aniônicas no modo flowthrough, onde as impurezas interagem com a resina e o anticorpo é coletado na fração nãoadsorvida (Knudsen et al., 2001).

A cromatografia de afinidade é uma técnica de separação e purificação de proteínas baseada na afinidade das proteínas pelos ligantes da resina. Esse ligante pode ser, por exemplo, um anticorpo contra a proteína alvo ou um metal de transição. O princípio fundamental da cromatografia de afinidades por metal (IMAC) consiste na interação entre as proteínas em solução e os íns metálicos imobilizados no suporte sólido ou matriz. Estes suportes contendo íons de $\mathrm{Cu}^{2+}, \mathrm{Ni}^{2+}, \mathrm{Zn}^{2+}$ ou $\mathrm{Co}^{2+}$ são apropriados para o fracionamento de proteínas que contenham histidina, cisteína, cadeias laterais aromáticas de aminoácidos e de grupos $\mathrm{N}$-terminal acessíveis destes aminoácidos (Porath, 1992). Estes resíduos devem estar disponíveis na superfície das proteínas para que exista interação com os metais de transição. A escolha do metal deve ser feita de acordo com o tipo e quantidade desses resíduos na superfície da proteína, conforme Tabela 2.

\begin{tabular}{c|c}
$\begin{array}{c}\text { Presença de histidina ou triptofano na } \\
\text { superfície da proteína }\end{array}$ & $\begin{array}{c}\text { Íons metálicos que fornecem } \\
\text { adsorção }\end{array}$ \\
\hline Nenhum His/Trp & - \\
\hline Uma His & $\mathrm{Cu}^{2+}$ \\
\hline Mais de uma His & $\mathrm{Cu}^{2+}($ adsorção mais forte $), \mathrm{Ni}^{2+}$ \\
\hline Cluster de His & $\mathrm{Cu}^{2+}, \mathrm{Ni}^{2+}, \mathrm{Zn}^{2+}, \mathrm{Co}^{2+}$ \\
\hline Vários Trp, nenhuma His & $\mathrm{Cu}^{2+}$
\end{tabular}

Tabela 2 - Relação entre presença de His/Trp na superfície da proteína e íons metálicos que oferecem adsorção

Fonte: Adaptado de Janson e Rydén (1998) 
As proteínas que não contêm esses grupos funcionais (His, Cys, Trp e Phe) na sua forma natural disponíveis na superfície para coordenação de metais podem ser modificadas através de engenharia genética para incluir uma cauda de seis ou mais histidinas consecutivas no N- ou C-terminal (Karmali, 2000). Com isso, estas proteínas geneticamente manipuladas passam a ter afinidade pelos quelatos de metal e podem ser purificadas por IMAC. Os íons de cobre, níquel, zinco e cobalto variam em sua afinidade e especificidade por histidinas conforme a Figura 6. Enquanto os íons $\mathrm{Ni}^{2+}$ apresentam alta afinidade e baixa especificidade, íons $\mathrm{Co}^{2+}$ são mais específicos, mas possuem menor afinidade por histidinas e, por isso, são uma opção para reduzir a ligação de proteínas não-específicas (Janson e Rydén, 1998).

Figura 6 - Afinidade e especificidade de diferentes íons metálicos por histidinas

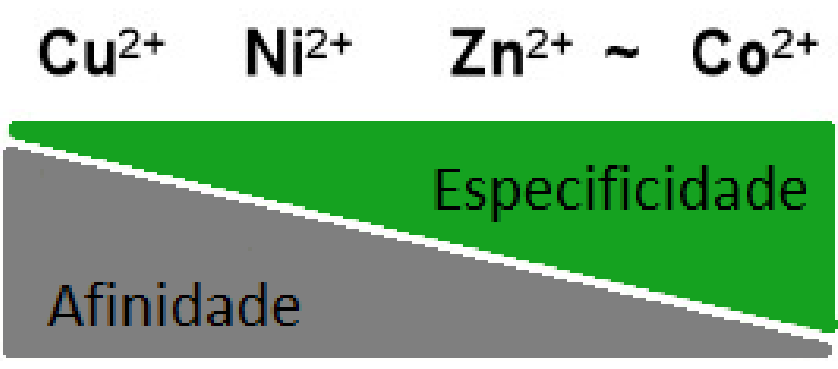

Fonte: Adaptado de Jena Bioscience (2016).

A cromatografia de interação hidrofóbica, por sua vez, baseia-se nas propriedades hidrofóbicas de algumas proteínas. As proteínas devem ser colocadas na presença de elevada concentração de sal, sendo sulfato de amônio o mais empregado. O sal aumenta a entropia da água, aumentando, assim, as interações hidrofóbicas e também pode estabilizar as proteínas. As porções hidrofóbicas da coluna são ligadas às áreas hidrofóbicas das moléculas. Quanto mais hidrofóbico for o constituinte, mais forte será a ligação à coluna. Na presença de elevadas concentrações de sal, os grupos hidrofóbicos da matriz impedem a passagem de porções das proteínas hidrofóbicas. Pode-se controlar a separação de diferentes proteínas reduzindo a concentração do sal ou adicionando solventes (Janson e 
Rydén, 1998). Este tipo de interação já foi utilizado para purificação de pneumolisina recombinante (Mitchell et al., 1989).

A cromatografia de exclusão molecular separa as moléculas de uma solução de acordo com seu tamanho (Figura 7). Quando a fase móvel é aquosa, também é conhecida como cromatografia de gel filtração. As proteínas em solução injetadas na coluna são separadas pelo seu tamanho, da maior para a menor, devido à incompatibilidade entre as dimensões dos solutos e o tamanho dos poros da matriz. Assim, moléculas maiores não conseguem entrar nos poros da matriz e são eluídas primeiro, enquanto moléculas menores penetram nos poros e têm seu percurso retardado através da matriz (Max Planck Institute for Polymer Research, 2003).

Figura 7 - Esquema ilustrado de cromatografia de exclusão molecular

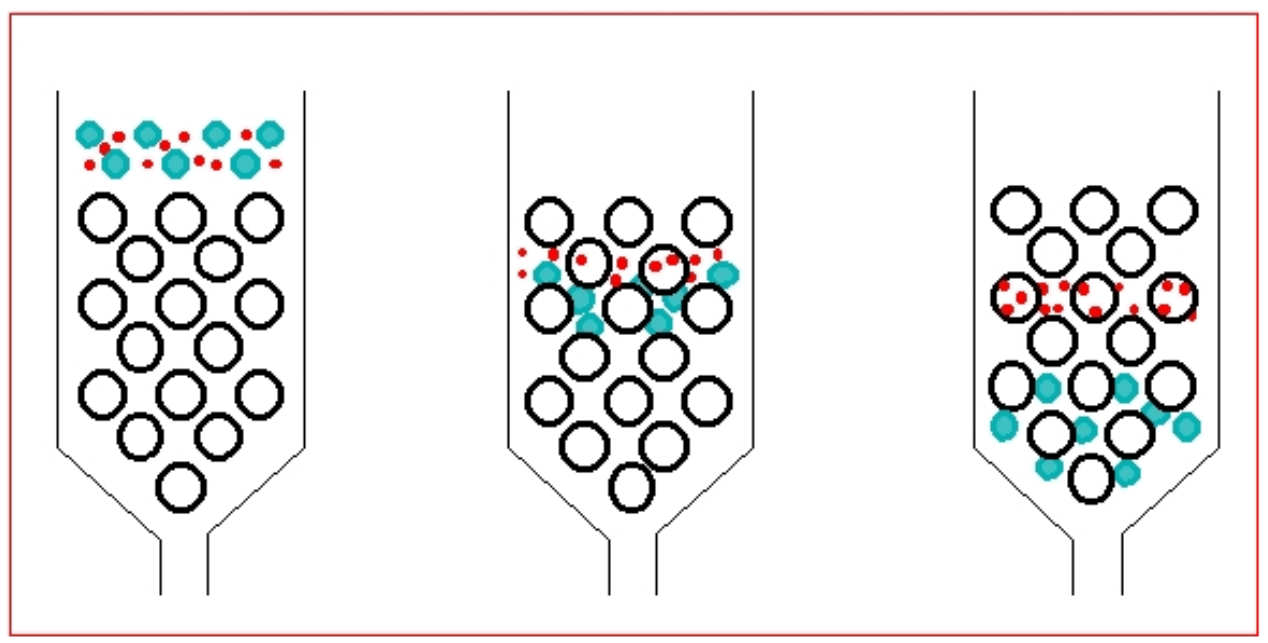

Fonte: (Max Planck Institute for Polymer Research, 2003).

Apesar de ser uma técnica aparentemente simples e direta, existem alguns pontos importantes a serem considerados antes de realizá-la. É necessário selecionar uma matriz que seja compatível com as propriedades da amostra e que possua uma faixa de separação adequada. Parâmetros importantes como: resolução, volume e viscosidade da amostra a ser injetada na coluna e tempo de residência devem ser analisados. Entretanto, todos esses parâmetros são influenciados pela escolha das dimensões da coluna, eficiência de empacotamento e número de pratos teóricos (Janson e Rydén, 1998). 
As técnicas cromatográficas clássicas são empregadas há algumas décadas na indústria biotecnológica. Nos últimos anos novas soluções têm conquistado espaço como, por exemplo, monólitos de uso único, que são usados como membranas de cromatografia e de filtração ao mesmo tempo (Sartorius Stedim, 2017). Essa solução traz ainda a vantagem de se excluir o problema de sanitização e definição de vida útil das resinas na produção industrial. Estudos já demonstraram que a substituição de resinas de troca aniônica por membranas de troca aniônica de uso único para remoção de baixos níveis de impurezas como DNA, proteínas do hospedeiro e vírus pode ser vantajosa na purificação de anticorpos monoclonais (Knudsen et al., 2001).

\subsection{Estabilidade de proteínas recombinantes}

A estabilidade molecular de proteínas tem um papel dos mais importantes quando se pensa em produzir um fármaco ou vacina. São os estudos de estabilidade que vão determinar, primeiramente, se a proteína está apta a compor a formulação do fármaco e, também, quais serão as condições de sua armazenagem, transporte e via de administração no paciente. Wang (1996) apontou a instabilidade proteica como sendo uma das principais causas pelas quais os biofármacos, uma classe composta sobretudo por proteínas, são tradicionalmente injetáveis ao invés de orais, administração mais comum para fármacos compostos por pequenas moléculas, e também é por isso que geralmente os biofármacos requerem armazenamento a baixas temperaturas e até mesmo congelados.

Uma causa conhecida de instabilidade de proteínas é a formação de agregados. A interação hidrofóbica constitui a principal força envolvida no enovelamento de proteínas. A maioria das cadeias apolares tende a se localizar para "dentro" da molécula, não tendo contato com a água. Quando o enovelamento não é capaz de esconder a maioria dos aminoácidos apolares, a interação entre esses resíduos pode levar à formação de agregados, que geralmente apresentam menor solubilidade, atividade e imunogenicidade (Wang, 1999).

A exposição de aminoácidos mais suscetíveis a modificações químicas para o lado de "fora" da molécula também pode favorecer degradações químicas como hidrólise, oxidação, quebra de pontes dissulfeto e desamidação. Esta última é uma 
reação química entre resíduos de aminoácidos. Ela ocorre entre aminoácidos lábeis, como por exemplo Asn-Gly. Xie e Schowen (1999) apontam que ambas as estruturas secundárias, $\alpha$-hélice e folha- $\beta$ são responsáveis por estabilizar os resíduos de Asn para que não ocorra desamidação. Logo, problemas conformacionais tendem a ser a causa desse tipo de degradação.

As instabilidades químicas de proteínas também podem decorrer de exposição à temperatura, pH e pressão desfavoráveis (Arakawa et al., 2001).

Para estabilizar proteínas em solução, o mais comum é usar excipientes na formulação que sejam capazes de impedir a degradação ou ao menos retardá-la. Um dos excipientes mais utilizados nas formulações proteicas é a trealose. A trealose é um dissacarídeo de glicose utilizado em muitos produtos comerciais como Herceptin e Avastin (Ohtake e Wang, 2011).

Moléculas como trealose, sacarose e glicerol são capazes de impedir a desidratação das proteínas, importante causa de degradação. Elas interagem através de ligações de hidrogênio à superfície da proteína formando uma camada protetora, mantendo assim sua conformação e atividade (Liao et al., 2002; Kaushik e Bhat, 2003; Ohtake e Wang, 2011; Singh et al., 2011).

Segundo Wang (1999), apesar de vários fatores que influenciam a estabilidade das proteínas serem conhecidos, diferenças de estrutura entre proteínas distintas são tão significativas que generalizações de estratégias de estabilização muito dificilmente podem ser feitas e, com isso, frequentemente as proteínas tem de ser avaliadas caso a caso e sua estabilidade estudada empiricamente.

Cada vez mais a engenharia de proteínas avança e permite a criação de proteínas únicas, cada vez mais distintas das naturais. Com isso cresce a necessidade de encontrar formas de predizer a estabilidade dessas proteínas. Alguns estudos que utilizam modelos baseados em banco de dados de proteínas conhecidas têm tentado preencher esta lacuna (Pires et al., 2014; Laimer et al., 2016; Pandurangan et al., 2017). 


\subsection{Moléculas híbridas e espaçadores moleculares}

As proteínas de fusão são uma nova classe de biomoléculas com propriedades multifuncionais. A fusão genética de dois ou mais domínios de proteínas é feita quando se quer combinar, aumentar ou modificar o caráter de ambas as proteínas. No caso de enzimas e antígenos, estudos mostraram que a junção de duas proteínas distintas pode levar a um aumento da atividade enzimática ou antigênica de cada uma delas ou ainda a uma atividade sinérgica de ambas (Zhao et al., 2008; Lu et al., 2009; Goulart et al., 2013; Lee et al., 2013).

A estratégia de produzir proteínas geneticamente fusionadas foi empregada com sucesso na vacina $4 \mathrm{CMenB}$, contra meningite causada por Neisseria meningitidis. Esta vacina está disponível no Brasil desde 2015. Ela possui em sua composição 5 proteínas: NadA, NHBA, GNA1030, fHbp e GNA2091. Estes 5 antígenos estão na forma de 3 proteínas: a NadA e duas proteínas recombinantes fusionadas, sendo a NHBA fusionada com a GNA1030 e a GNAgna2091 com a fHbp. A imunogenicidade desta vacina foi comprovada pelo aumento do título de anticorpos do soro com atividade bactericida em $90 \%$ dos participantes dos ensaios clínicos (Findlow et al., 2010; Sadarangani e Pollard, 2010; Panatto et al., 2011; Santolaya et al., 2012).

O medicamento Etanercept, ou Enbrel (do laboratório Amgen), que é utilizado no tratamento de artrite e psoríase, é fabricado por tecnologia de DNA recombinante na forma de uma proteína de fusão que consiste no domínio de ligação ao ligante extracelular do receptor-2 do fator de necrose tumoral humano (TNFR2/p75) geneticamente fusionado ao domínio $F c$ da lgG1 humana. O etanercept tem uma massa molecular aparente de aproximadamente 150 kDa (Hutmacher et al., 2007; Amgen, 2015). Este medicamento teve sua primeira aprovação pelo FDA em 1998 (Amgen, 2015).

O trabalho de Spiegel et al. (2015) relatou a otimização de uma vacina para malária composta de uma proteína de fusão contendo 5 fragmentos de diferentes antígenos. A otimização foi feita deletando do gene do híbrido sequências de sítios de degradação por proteases do hospedeiro em Pichia pastoris.

Alguns estudos já foram feitos utilizando proteínas híbridas de pneumolisóides com outras proteínas de pneumococo. Uma vacina composta de dPly e CbpA (ou 
PspC) geneticamente fusionadas demonstrou sinergia entre os componentes ao invés de apenas apresentar um resultado aditivo na proteção para ambas as proteínas (Mann et al., 2014). Uma formulação contendo dPly e PsaA fusionadas foi capaz de confirmar a utilidade da pneumolisina como um adjuvante de mucosa (Douce et al., 2010). Uma formulação trivalente contendo uma proteína híbrida de CbpA (ou PspC) e dPly administrada em conjunto com PspA demonstrou ampla proteção para diferentes doenças, como sepse, pneumonia e meningite, causadas por diferentes serotipos em diferentes modelos animais (Chen et al., 2015).

O conhecimento de espaçadores moleculares naturais é muito útil para o desenho de espaçadores a serem usados em proteínas híbridas (Chen et al., 2013). As proteínas recombinantes de fusão, assim como as proteínas com mais de um domínio que existem na natureza, são compostas de um ou mais domínios funcionais unidos por um peptídeo espaçador (Reddy Chichili et al., 2013). Esse peptídeo espaçador tem a função de conectar as partes da proteína e manter a interação cooperativa dos domínios ou preservar a atividade biológica de cada domínio.

Existem dois tipos principais de espaçadores moleculares ou linkers: rígidos e flexíveis. Os linkers flexíveis são geralmente utilizados quando os domínios requerem um grau de interação ou de movimento. Eles são geralmente compostos de aminoácidos pequenos, sem cadeia lateral, como glicinas e serinas. O linker (GGGGS)n já foi utilizado com sucesso em diversas construções (Zhao et al., 2008; Lu et al., 2009).

Já os linkers rígidos são indicados quando é importante manter uma distância fixa entre os domínios da proteína híbrida e manter as suas funções independentes. Eles podem ser sequências compostas de repetições de prolinas e alaninas ou sequências que formam uma alfa-hélice. O linker $A(E A A A K){ }_{n} A$, que forma uma $\alpha$ hélice, se mostrou eficaz na separação dos domínios de proteínas híbridas em diversos estudos (Arai et al., 2001; Arai et al., 2004; Zhao et al., 2008; Lu et al., 2009).

O desenho de espaçadores moleculares é hoje uma importante ferramenta para obtenção de proteínas híbridas estáveis e com aplicações farmacêuticas. A inserção de espaçadores moleculares rígidos e flexíveis já foi utilizada com sucesso para aumentar a estabilidade de uma proteína híbrida composta de albumina de soro humano (HSA) e interferon- $\alpha 2 b$. O híbrido apresentou instabilidade quando suas 
sequências foram clonadas justapostas, porém a inserção de espaçadores moleculares entre as proteínas tornou o híbrido estável, além de aumentar a sua recuperação no processo de purificação e a sua atividade antiviral (Zhao et al., 2008). 


\section{OBJETIVOS}

\subsection{Objetivo geral}

Produzir, purificar e avaliar resposta imunológica em camundongos de moléculas híbridas recombinantes compostas das proteínas de pneumococo PspA94 e PdT ligadas ou não entre si por meio de espaçadores moleculares.

\subsection{Objetivos específicos}

a) Construir os genes para expressão das moléculas híbridas com espaçador rígido (PspA94-RL-PdT) e flexível (PspA94-FL-PdT) empregando a reação de overlap extension PCR;

b) Realizar cultivos em frasco agitado e biorreator para obtenção de PspA94-RLPdT e PspA94-FL-PdT e purificá-las;

c) Purificar o híbrido sem espaçador PspA94-PdT proveniente da construção obtida anteriormente no laboratório a partir de bactérias cultivadas em biorreator;

d) Avaliar a estabilidade dos híbridos na presença ou ausência de agentes estabilizantes;

e) Imunizar camundongos com as proteínas híbridas com e sem espaçador e desafiá-los com S. pneumoniae para comparar a proteção fornecida pelas moléculas.

f) Avaliar a capacidade do soro provenientes dos camundongos imunizados de inibir a atividade hemolítica da pneumolisina. 


\section{MATERIAIS E MÉTODOS}

A clonagem do híbrido sem espaçador foi realizada no Laboratório de Biotecnologia Molecular IV do Centro de Biotecnologia do Instituto Butantan, sob orientação da Dra. Luciana Leite e os cultivos em biorreatores foram realizados pela equipe do LaDaBio da UFSCar, sob orientação da Profa. Dra. Teresa Cristina Zangirolami. Para a construção desse híbrido foi utilizada a cepa de E. coli M15 contendo o plasmídeo pQE-30 + PspA94-PdT.

A PspA foi clonada a partir do isolado clínico ST94/01 fornecido pelo Instituto Adolfo Lutz. Classificada como pertencente ao clado 2 da família 1, mostrou ter boa reatividade cruzada com diversas PspA de ambos os clados da família 1 (Goulart et al. 2011). O toxóide PdT usado foi o descrito por Berry et al. (1995), que possui 3 mutações: Asp-385 $\rightarrow$ Asn, Cys- $428 \rightarrow$ Gly e Trp- $433 \rightarrow$ Phe. A descrição de cada mutação está no item 2.4 .

Nesta construção as duas proteínas do híbrido encontram-se justapostas, sem qualquer sequência espaçadora entre elas, e o híbrido é produzido com cauda de histidina $\mathrm{N}$-terminal. Assim, este trabalho descreve a clonagem, produção e purificação dos híbridos com espaçadores, a purificação do híbrido sem espaçador e a análise da estabilidade de ambos os tipos de híbridos.

\subsection{Estratégia para obtenção dos híbridos PspA94-PdT com espaçadores moleculares}

Para obtenção dos híbridos com espaçador, dois espaçadores moleculares diferentes foram empregados: um espaçador flexível, formado por glicinas e serinas, cuja sequência de bases é 5' GGGGSGGGGS 3' e foi denominado FL; e um rígido, que forma uma estrutura de alfa-hélice, cuja sequência é 5' AEAAAKEAAAKA 3' e foi denominado RL. Além disso, a última região rica em prolinas da PspA94 foi removida dessa nova construção, pois PspA de outros clados foram purificadas em nosso laboratório e as que não apresentam essa região, como a PspA4Pro (Moreno et al., 2010) e a PspA3 (Carvalho et al., 2012), mostraram-se mais estáveis, enquanto a 
PspA245, em cuja sequência a região foi mantida e também foi purificada em nosso laboratório (Barazzone et al., 2011), apresentou problemas de estabilidade (Dra Giovanna Barazzone, comunicação pessoal).

\subsection{Obtenção dos genes de PspA94 e PdT unidos por espaçadores}

Para clonagem dos híbridos com espaçadores foi utilizada a técnica de overlap extension PCR (Figura 8) com polimerase de alta-fidelidade (Q5 high fidelity DNA polymerase, New English Biolabs), onde são realizadas 2 reações de PCR em paralelo para amplificar os genes de cada proteína com um trecho do espaçador ou com a sequência inteira do espaçador e uma terceira reação de PCR em série para unir os produtos das reações anteriores (Ho et al., 1989; Reikofski e Tao, 1992; Bryksin e Matsumura, 2010). Também foi avaliada a reação de overlap extension PCR utilizando gradiente de temperatura de anelamento, de $70 \stackrel{\circ}{\circ}$ até $55^{\circ} \mathrm{C}$. O gradiente da temperatura de anelamento teve por objetivo aumentar o rendimento da reação (New English Biolabs, 2015).

Os primers foram desenhados de modo a inserir a região espaçadora (o linker) entre a PspA94 e a PdT, para isso foi empregada a calculadora de temperatura de melting e annealing online da New England Biolabs (New England Biolabs, 2014). Os primers estão apresentados na Tabela 3.

As condições ótimas para as reações de amplificação foram definidas após avaliação de diferentes temperaturas de anelamento (55 a $70 \stackrel{\circ}{\circ}$ ) e diferentes concentrações de cloreto de magnésio (1 a 4 mM).

Os produtos de PCR foram analisados através de eletroforese em gel de agarose 0,8 ou $1 \%$. As bandas do gel foram purificadas utilizando-se kit de purificação GFX PCR DNA and Gel Band Purification Kit (GE Healthcare) e a concentração de ácidos nucleicos das amostras foi determinada utilizando nanodrop (Epoch Microplate Spectrophotometer - Bio-Tek). 
Figura 8 - Mecanismo de inserção dos espaçadores nas proteínas híbridas por overlap extension PCR

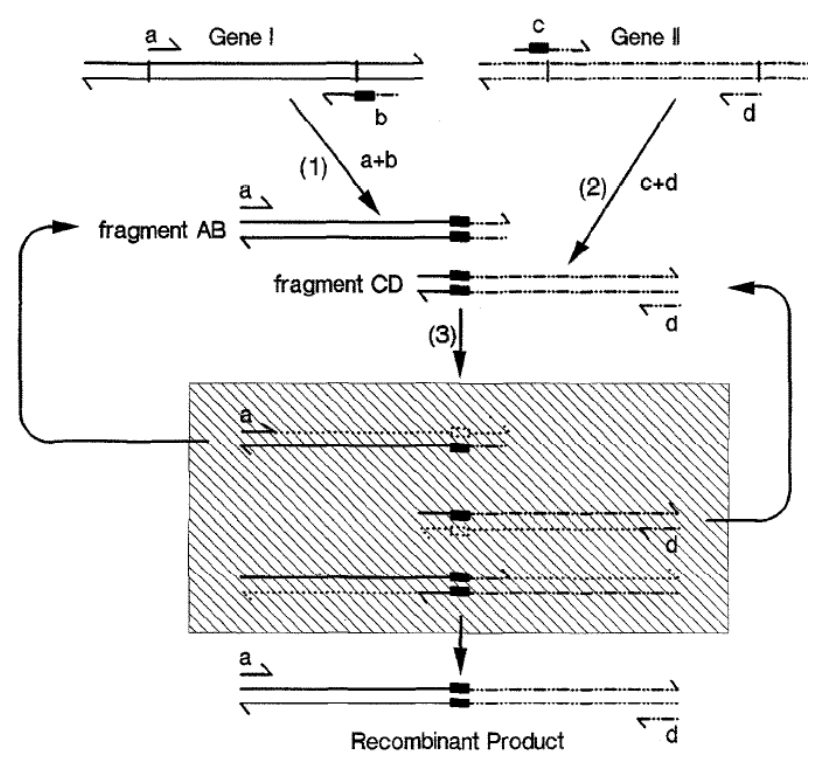

Fonte: (Horton et al., 1989)

\begin{tabular}{|c|c|c|c|}
\hline \multirow{6}{*}{$\begin{array}{l}\text { ㅇ } \\
0 \\
\frac{1}{1} \\
4 \\
\frac{1}{\dot{y}} \\
\frac{0}{4} \\
\frac{0}{0} \\
0\end{array}$} & \multirow{4}{*}{ 1 PCR } & \multirow{2}{*}{$\begin{array}{l}\text { PspA94 + linker } \\
\text { flexível }\end{array}$} & 5' CCATGGCAGAAGCGCCCGTAGCTA 3' \\
\hline & & & $\begin{array}{l}\text { 5' TGAACCTCCGCCCCCAGACCCGCCTCCACCTGGA } \\
\text { GCTGGAGCTG 3' }\end{array}$ \\
\hline & & \multirow{2}{*}{$\begin{array}{l}\text { PdT + linker } \\
\text { flexível }\end{array}$} & 5' CTCGAGGTCATTTTCTACCTTATCCTCTACCTGA 3' \\
\hline & & & $\begin{array}{l}\text { 5' GGTGGAGGCGGGTCTGGGGGCGGAGGTTCAATG GCAA } \\
\text { ATAAAGCAGTAAATG 3' }\end{array}$ \\
\hline & \multirow{2}{*}{ 2o PCR } & \multirow{2}{*}{$\begin{array}{l}\text { Amplificação do } \\
\text { híbrido com linker } \\
\text { flexível }\end{array}$} & 5' CCATGGCAGAAGCGCCCGTAGCTA 3' \\
\hline & & & 5' CTCGAGGTCATTTTCTACCTTATCCTCTACCTGA 3' \\
\hline \multirow{6}{*}{$\begin{array}{l}\frac{5}{0} \\
\frac{1}{1} \\
\frac{1}{01} \\
\dot{1} \\
\frac{9}{4} \\
\frac{0}{0} \\
\frac{0}{0}\end{array}$} & \multirow{4}{*}{ 1 PCR } & \multirow{2}{*}{$\begin{array}{l}\text { PspA94 + trecho do } \\
\text { linker rígido }\end{array}$} & 5' CCATGGCAGAAGCGCCCGTAGCTA 3' \\
\hline & & & $\begin{array}{l}\text { 5' TTCTTTAGCTGCAGCTTCTTTAGCTGCAGCT TCTGC } \\
\text { TGGAGCTGGAGCTGG 3' }\end{array}$ \\
\hline & & \multirow{2}{*}{$\begin{array}{l}\mathrm{PdT}+\text { trecho do } \\
\text { linker rígido }\end{array}$} & 5' CTCGAGGTCATTTTCTACCTTATCCTCTACCTGA 3' \\
\hline & & & $\begin{array}{l}\text { 5' GCTAAAGAAGCTGCAGCTAAAGAAGCTGCAGCTA } \\
\text { AAGCTATGGCAAATAAAGCAGTAAATGACTTTATAC TAGC 3' }\end{array}$ \\
\hline & \multirow{2}{*}{ 2 PCR } & \multirow{2}{*}{$\begin{array}{l}\text { Amplificação do } \\
\text { híbrido com linker } \\
\text { rígido }\end{array}$} & 5' CCATGGCAGAAGCGCCCGTAGCTA 3' \\
\hline & & & 5' CTCGAGGTCATTTTCTACCTTATCCTCTACCTGA3' \\
\hline
\end{tabular}

Tabela 3 - Primers desenhados para construção dos híbridos com espaçadores 


\subsection{Clonagem dos genes dos híbridos com espaçadores}

Como foi utilizada uma polimerase de alta-fidelidade para a reação de overlap e esta enzima produz fragmentos com extremidades blunt, os produtos de PCR foram purificados e uma reação de adenilação com a Taq DNA polimerase (GoTaq DNA polymerase, Promega) foi efetuada antes de ligá-los ao vetor de clonagem. A reação de adenilação foi realizada com uma concentração de final de $\mathrm{MgCl}_{2}$ 2,5 mM e dATP $0,2 \mathrm{mM}$ em um termociclador por $18 \mathrm{~min}$ a $70 \stackrel{\circ}{\circ} \mathrm{C}$ seguido de 2 min a $72{ }^{\circ} \mathrm{C}$. O produto da reação foi usado diretamente na reação de ligação com o vetor de clonagem pGEM-T easy vector (Promega), cujo esquema é apresentado na Figura 9.

Células competentes de E. coli DH5a foram transformadas com os plasmídeos carregando os genes com espaçadores pspA94-RL-pdt (rígido) ou pspA94-FL-pdt (flexível). Com as construções obtidas foram feitos screening de colônias, mapas de restrição e sequenciamento. Os mapas de restrição foram realizados com enzimas que cortam o plasmídeo com o inserto em 2 ou mais fragmentos.

Figura 9 - Mapa do vetor de clonagem pGEM-T esasy vector

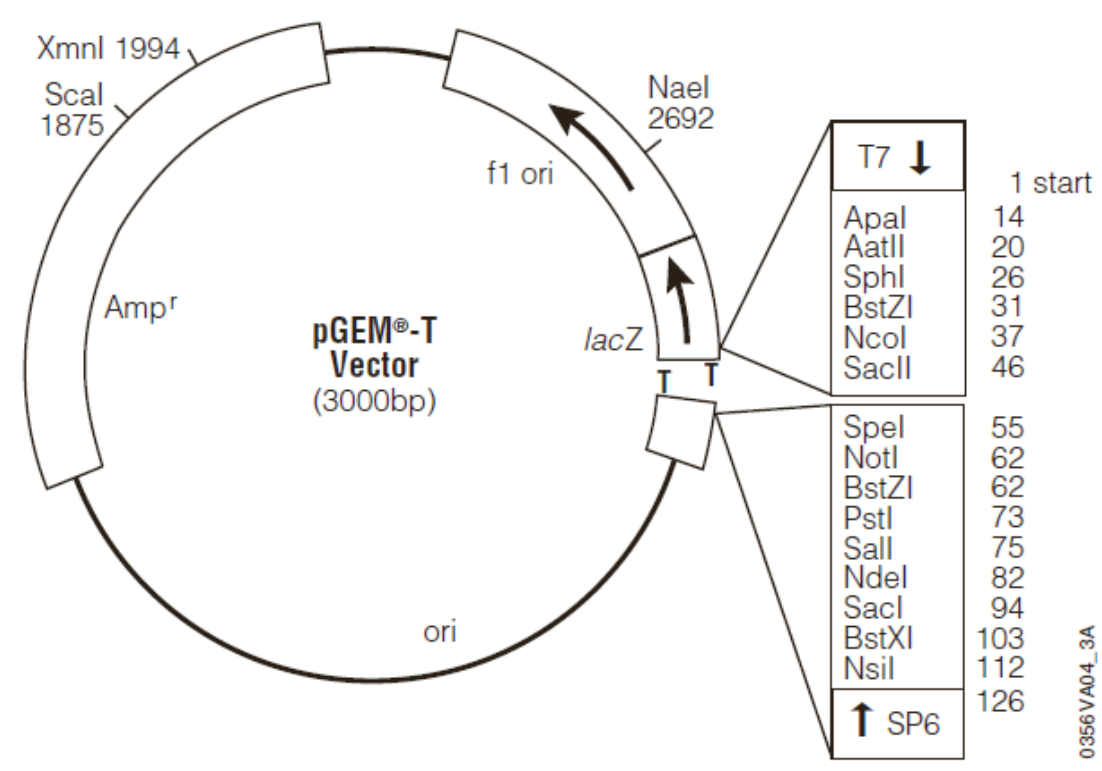

Fonte: (Promega, 2010). 
A purificação do DNA plasmidial das colônias foi feita com kit de purificação Illustra plasmidPrep Mini Spin Kit (GE Healthcare).

O plasmídeo comercial pET-28a (Novagen) foi digerido com as enzimas Ncol e Xhol e tratado com fosfatase alcalina intestinal de bezerro (CIAP, Promega) para remover os grupos fosfato das extremidades 5' e evitar seu religamento. Posteriormente, os vetores de clonagem com os insertos foram digeridos com as mesmas enzimas de restrição e o inserto foi ligado ao vetor de expressão cujo esquema é apresentado na Figura 10.

Os construtos resultantes foram inseridos nas linhagens de expressão $E$. coli BL21(DE3), E. coli BL21 Star (DE3) pLysS e E. coli Rosetta (DE3) e os transformantes foram avaliados quanto à produção da proteína heteróloga em cultivo em frascos agitados.

Figura 10 - Mapa do vetor de expressão pET-28

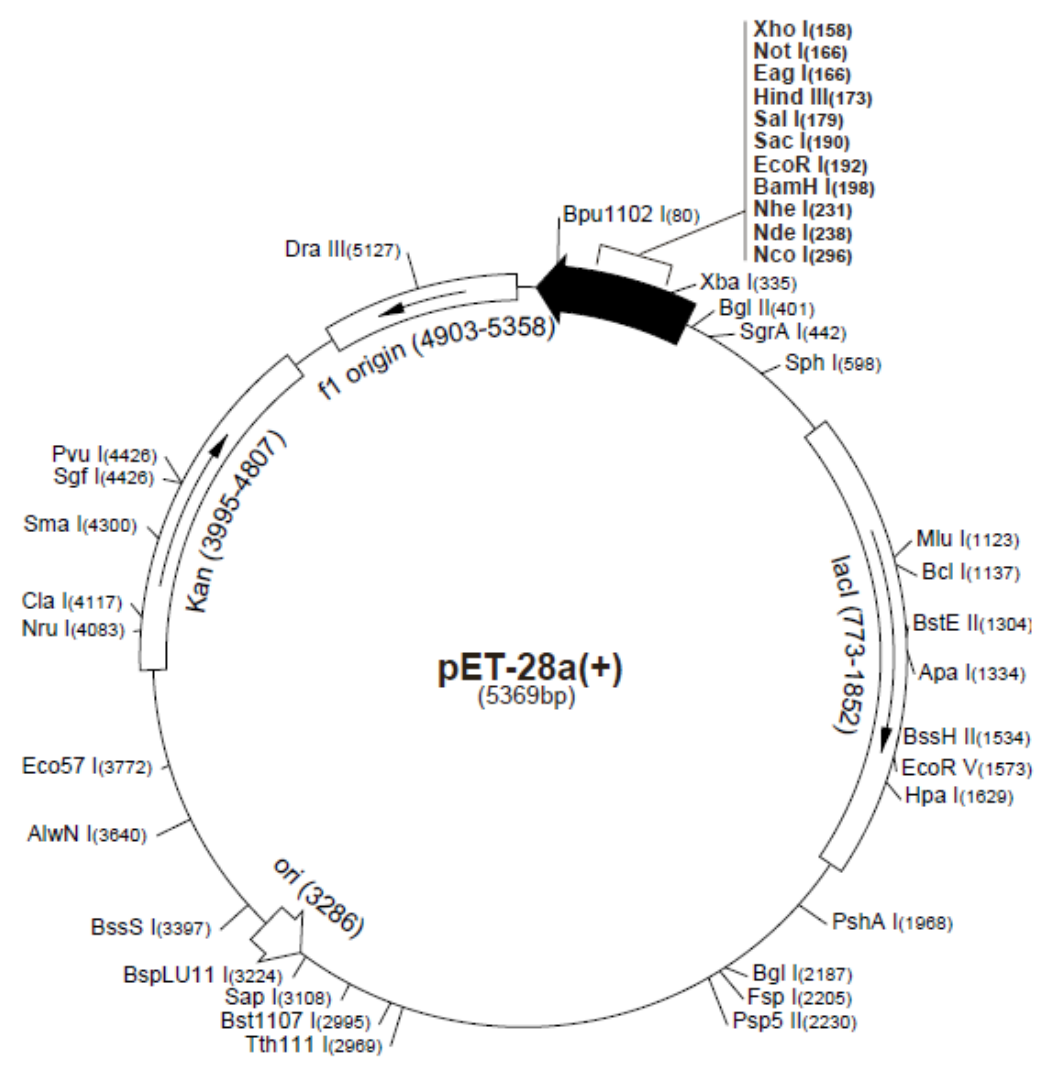

Fonte: (Novagen, 1998) 


\subsection{Avaliação da síntese das proteínas com espaçadores e da estabilidade dos clones}

Os clones selecionados foram cultivados em frascos erlenmeyers com $50 \mathrm{~mL}$ de meio LB com antibiótico adequado para cada cepa, a $37 \stackrel{\circ}{\mathrm{C}}$ e $250 \mathrm{rpm}$, com densidade óptica (DO) a $600 \mathrm{~nm}$ inicial de aproximadamente 0,1. A DO foi acompanhada e a indução foi feita com IPTG $1 \mathrm{mM}$ quando ela atingiu aproximadamente 1,0. Amostras de $1 \mathrm{~mL}$ do cultivo foram coletadas antes e depois da indução, centrifugadas e o pellet empregado para verificação da produção da proteína por SDS-PAGE (gel 10\%).

Amostras do cultivo antes e depois da indução também foram plaqueadas em meio LB sem antibiótico para posterior análise da estabilidade do plasmídeo. A análise foi feita repicando colônias em placas com e sem antibiótico e verificando a porcentagem das colônias com crescimento na placa com antibiótico em relação à placa sem antibiótico. A composição do meio LB é apresentada na Tabela 4 e as concentrações de antibióticos estão na Tabela 5.

\begin{tabular}{c|c} 
Componente & Concentração \\
\hline Triptona & $10 \mathrm{~g} / \mathrm{L}$ \\
\hline Extrato de levedura & $5 \mathrm{~g} / \mathrm{L}$ \\
\hline $\mathrm{NaCl}$ & $10 \mathrm{~g} / \mathrm{L}$ \\
\hline Ágar (para meio sólido) & $15 \mathrm{~g} / \mathrm{L}$ \\
\hline $\mathrm{pH}$ & 7,5
\end{tabular}

Tabela 4 - Composição meio Luria Bertani (LB) 


\begin{tabular}{c|c} 
Construção & Antibióticos \\
\hline E. coli M15 + pQE-30/pspA94-pdT & $\begin{array}{c}\text { canamicina } 25 \mu \mathrm{g} / \mathrm{ml} \mathrm{e} \\
\text { ampicilina } 100 \mu \mathrm{g} / \mathrm{ml}\end{array}$ \\
\hline E. coli BL21 Star (DE3)pLysS + pET-28a/pspA94-FL-pdT & $\begin{array}{c}\text { cloranfenicol } 34 \mu \mathrm{g} / \mathrm{ml} \mathrm{e} \\
\text { canamicina } 30 \mu \mathrm{g} / \mathrm{ml}\end{array}$ \\
\hline E. coli Rosetta (DE3) + pET-28a/pspA94-FL-pdT & $\begin{array}{c}\text { cloranfenicol } 34 \mu \mathrm{g} / \mathrm{ml} \mathrm{e} \\
\text { canamicina } 30 \mu \mathrm{g} / \mathrm{ml}\end{array}$ \\
\hline E. coli BL21 Star (DE3)pLysS + pET-28a/pspA94-RL-pdT & $\begin{array}{c}\text { cloranfenicol } 34 \mu \mathrm{g} / \mathrm{ml} \mathrm{e} \\
\text { canamicina } 30 \mu \mathrm{g} / \mathrm{ml}\end{array}$ \\
\hline E. coli BL21(DE3) + pET-28a/pspA94-RL-pdT & canamicina $30 \mu \mathrm{g} / \mathrm{ml}$
\end{tabular}

Tabela 5. Concentrações de antibióticos utilizados no meio com cada construção.

Western Blotting (item 4.9) foi utilizado para verificação do reconhecimento da molécula por anticorpos produzidos em coelho contra célula inteira de pneumococo, portanto capazes de reconhecer ambas as proteínas.

\subsection{Determinação da correlação entre densidade óptica e massa seca}

Um cultivo de $1 \mathrm{~L}$ com meio LB foi realizado em frasco tipo Tunair (Figura 11), para determinação da correlação entre densidade óptica e massa seca. O frasco Tunair é um frasco otimizado para cultivo celular aeróbio, já que contém um formato que permite grande área superficial para troca gasosa, chicanas que facilitam a oxigenação do meio e favorecem o crescimento celular, além de uma membrana semipermeável que favorece a entrada de $\mathrm{O}_{2}$ e saída de $\mathrm{CO}_{2}$ do frasco. 
Figura 11 - Frasco Tunair 2,5 L

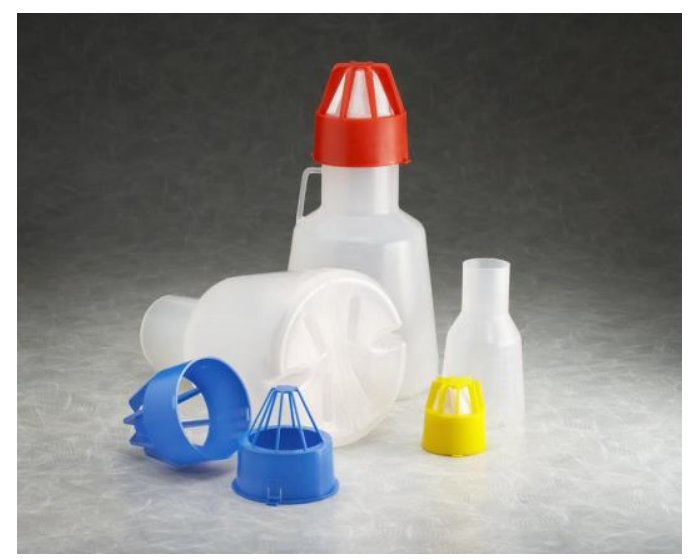

Fonte: https://www.ibisci.com/collections/2-5l-tunair-shake-flasks

O cultivo foi encerrado antes deste alcançar a fase estacionária e a suspensão foi inativada com formalina $2 \%(\mathrm{v} / \mathrm{v})$ por aproximadamente $20 \mathrm{~h}$ a temperatura ambiente. A suspensão de células inativadas foi centrifugada e ressuspendida em 50 $\mathrm{mL}$ de salina. A partir deste concentrado, foram realizadas dez diluições diferentes e a DO de cada suspensão resultante foi determinada. Alíquotas de $20 \mathrm{~mL}$ de cada diluição foram transferidas em duplicata para frascos previamente secos em estufa a $60^{\circ} \mathrm{C}$ até massa constante. As alíquotas foram centrifugadas a $14.696 \mathrm{~g} \mathrm{e} 4 \stackrel{\circ}{ } \mathrm{C}$ por 30 min, o sobrenadante foi descartado e os frascos com os pellets celulares foram mantidos em estufa a $60 \stackrel{\circ}{ } \mathrm{C}$ por pelo menos 2 dias ou até massa constante. A massa dos pellets foi então definida e, através do ajuste linear entre DO e massa seca de todas as alíquotas, a correlação foi determinada.

\subsection{Determinação do valor da velocidade específica máxima de crescimento celular}

Outro cultivo de 1 L e meio LB foi realizado em frasco Tunair para determinação da velocidade específica máxima de crescimento do clone.

O procedimento para obtenção do inóculo e retirada de amostras seguiu tal como descrito no item 4.4. Porém, ao invés de adicionarmos o IPTG para a indução da síntese da proteína híbrida, o cultivo foi mantido até a início de sua fase estacionária. A partir da DO a $600 \mathrm{~nm}$ das amostras retiradas de hora em hora foi 
possível determinar o início e o fim da fase exponencial de crescimento e determinar o valor da velocidade específica de crescimento, Hmáx, através da equação 1.

Equação 1 - Velocidade máxima específica de crescimento celular

$$
\mu_{\text {máx }}=\frac{1}{x} \cdot \frac{d x}{d t}
$$

\subsection{Cultivos para produção dos híbridos com espaçadores}

Os clones com genes da proteína híbrida com espaçador previamente selecionados (item 4.4) foram também cultivados para produção da molécula e sua posterior purificação.

Foram realizados cultivos em frascos Tunair de $1 \mathrm{~L}$ utilizando meio LB. Nesses cultivos dois inóculos de $50 \mathrm{~mL}$ foram incubados por aproximadamente $14 \mathrm{~h}$, partindose de uma colônia isolada em placa LB ágar com antibiótico. Esses frascos com 50 $\mathrm{mL}$ de células foram utilizados para inocular o cultivo de $1 \mathrm{~L}$ a uma DO inicial de 0,1 ou 0,2 . O crescimento celular foi monitorado de hora em hora para definir o momento de adição de IPTG para indução da síntese da proteína recombinante, quando DO > 2,0 .

Também foi realizado cultivo em biorreator de $10 \mathrm{~L}$ (batelada) utilizando meio quimicamente definido (CDM) para produção do híbrido com espaçador rígido, com 6 L de volume de operação. A composição do CDM é apresentada na Tabela 6.

Nesses cultivos, foram utilizados dois inóculos de $200 \mathrm{~mL}$ cada para iniciar 0 cultivo a uma DO de 0,1. O controle do biorreator foi setado de forma a manter a concentração de oxigênio dissolvido no meio a $30 \%$, variando os seguintes parâmetros em cascata: agitação, vazão de ar e vazão de oxigênio. $\mathrm{O}$ pH foi controlado em 6,7 e pela adição automática de $\mathrm{NH}_{4} \mathrm{OH} 24 \%$ (v/v) ao meio. Antiespumante (polipropilenoglicol $30 \% \mathrm{v} / \mathrm{v}$ ) foi adicionado manualmente sempre que necessário. 


\begin{tabular}{|c|c|}
\hline Componente & Concentração \\
\hline$\left(\mathrm{NH}_{4}\right)_{2} \mathrm{HPO}_{4}$ & $4 \mathrm{~g} / \mathrm{L}$ \\
\hline $\mathrm{KH}_{2} \mathrm{PO}_{4}$ & $13,3 \mathrm{~g} / \mathrm{L}$ \\
\hline Ácido cítrico. $\mathrm{H}_{2} \mathrm{O}$ & $1,7 \mathrm{~g} / \mathrm{L}$ \\
\hline $\mathrm{Fe}(\mathrm{III})$ citrato & $100,8 \mathrm{mg} / \mathrm{L}$ \\
\hline $\mathrm{CoCl}_{2} \cdot 6 \mathrm{H}_{2} \mathrm{O}$ & $2,5 \mathrm{mg} / \mathrm{L}$ \\
\hline $\mathrm{MnCl}_{2 \cdot} \cdot 4 \mathrm{H}_{2} \mathrm{O}$ & $15 \mathrm{mg} / \mathrm{L}$ \\
\hline 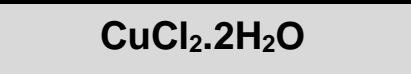 & $1,5 \mathrm{mg} / \mathrm{L}$ \\
\hline $\mathrm{H}_{3} \mathrm{BO}_{3}$ & $3 \mathrm{mg} / \mathrm{L}$ \\
\hline $\mathrm{Na}_{2} \mathrm{MoO}_{4 .} \mathbf{2} \mathrm{H}_{2} \mathrm{O}$ & $2,1 \mathrm{mg} / \mathrm{L}$ \\
\hline $\mathrm{Zn}\left(\mathrm{CH}_{3} \mathrm{COOH}\right)_{2 .} 2 \mathrm{H}_{2} \mathrm{O}$ & $33,8 \mathrm{mg} / \mathrm{L}$ \\
\hline EDTA & $14,1 \mathrm{mg} / \mathrm{L}$ \\
\hline $\mathrm{MgSO}_{4} .7 \mathrm{H}_{2} \mathrm{O}$ & $1,2 \mathrm{~g} / \mathrm{L}$ \\
\hline Tiamina & $45 \mathrm{mg} / \mathrm{L}$ \\
\hline Canamicina & $25 \mathrm{mg} / \mathrm{L}$ \\
\hline Glicose & $10 \mathrm{~g} / \mathrm{L}$ \\
\hline $\mathrm{HCl} 6 \mathrm{~N}$ & $4,15 \mathrm{~mL}$ \\
\hline$\overline{\mathrm{pH}}$ & $\overline{6,3}$ \\
\hline
\end{tabular}

Tabela 6 - Composição do meio quimicamente definido para E. coli

Fonte: Adaptado de Seeger et al. (1995)

A indução da expressão foi realizada após o total consumo da fonte de carbono através da adição de solução $20 \mathrm{~g} / \mathrm{L}$ de lactose com 0,1 mM de IPTG. O momento do total consumo de glicose no meio foi identificado pelo aumento abrupto da concentração de $\mathrm{O}_{2}$ no reator, que corresponde a um declínio acentuado no metabolismo do microorganismo devido ao esgotamento da fonte de carbono. 
A produção do híbrido nos cultivos em biorreator foi analisada através de SDSPAGE e a concentração de glicose residual das amostras de ambos os cultivos foi medida utilizando-se método enzimático.

Os dados de concentração de glicose no meio e de concentração celular permitiram o cálculo do fator de conversão de substrato em célula, $Y_{x / s}$, conforme a equação 2.

Equação 2 - Fator de conversão $Y_{x / s}$

$Y_{X / S}=\frac{X-X_{0}}{S_{0}-S}$, onde $\mathrm{X}=$ concentração celular e $\mathrm{S}=$ concentração de subtrato

\subsection{Purificação das proteínas híbridas com e sem espaçador}

As proteínas purificadas foram produzidas em biorreator pela equipe do Departamento de Engenharia Química da UFSCar e a biomassa mantida a $-80^{\circ} \mathrm{C}$ até a extração. Os híbridos foram produzidos intracelularmente e, por este motivo, as células foram centrifugadas para remover o meio de cultura e armazenadas a $-80 \stackrel{\circ}{\circ}$ até a extração. As proteínas híbridas foram obtidas na fração solúvel. A Figura 12 apresenta um diagrama de blocos das etapas dos processos de purificação realizados a partir da biomassa congelada. Foram realizados quatro processos de purificação da proteína híbrida sem espaçador PspA94-PdT combinando diferentes sequências das etapas cromatográficas intermediária e de polimento e um processo de purificação da proteína híbrida com espaçador molecular rígido (PspA94-RL-PdT). 
Figura 12 - Etapas do processo de purificação das proteínas híbridas

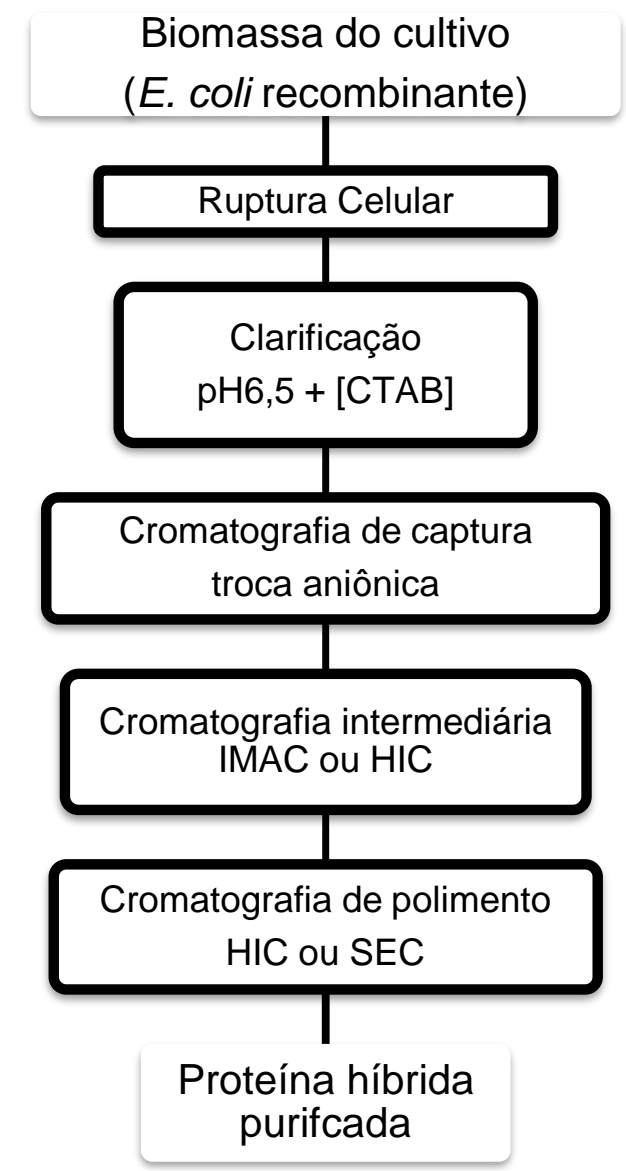

\subsubsection{Lise e clarificação}

Para extração, as células foram primeiramente descongeladas $\left(4^{\circ} \mathrm{C}\right) \mathrm{e}$ ressuspendidas no tampão de lise na relação de $100 \mathrm{~g}$ de biomassa úmida para $1 \mathrm{~L}$ de tampão de lise (tampão fosfato 10 mM pH 6,5 + 1mM EDTA + 1mM PMSF + 0,1\% Triton) com a ajuda de um mixer. EDTA é inibidor de metaloproteases e PMSF de serinoproteases, que são as principais classes de proteases de $E$. coli, e essa composição foi determinada anteriormente no nosso laboratório como eficiente para inibir a atividade proteolítica em extratos de E. coli BL21(DE3) (Carvalho, 2009).

A extração foi feita em homogeneizador contínuo de alta pressão (Figura 13), com um trocador de calor casco-tubo na saída e um reservatório dotado de camisa de resfriamento na entrada, ambos para controle da temperatura. Fixando-se a pressão 
e a temperatura, o tempo ideal para ruptura foi determinado através da quantificação de células lisadas pela DO e proteína liberada por tempo pela absorbância 280 nm.

Figura 13 - Sistema para ruptura celular

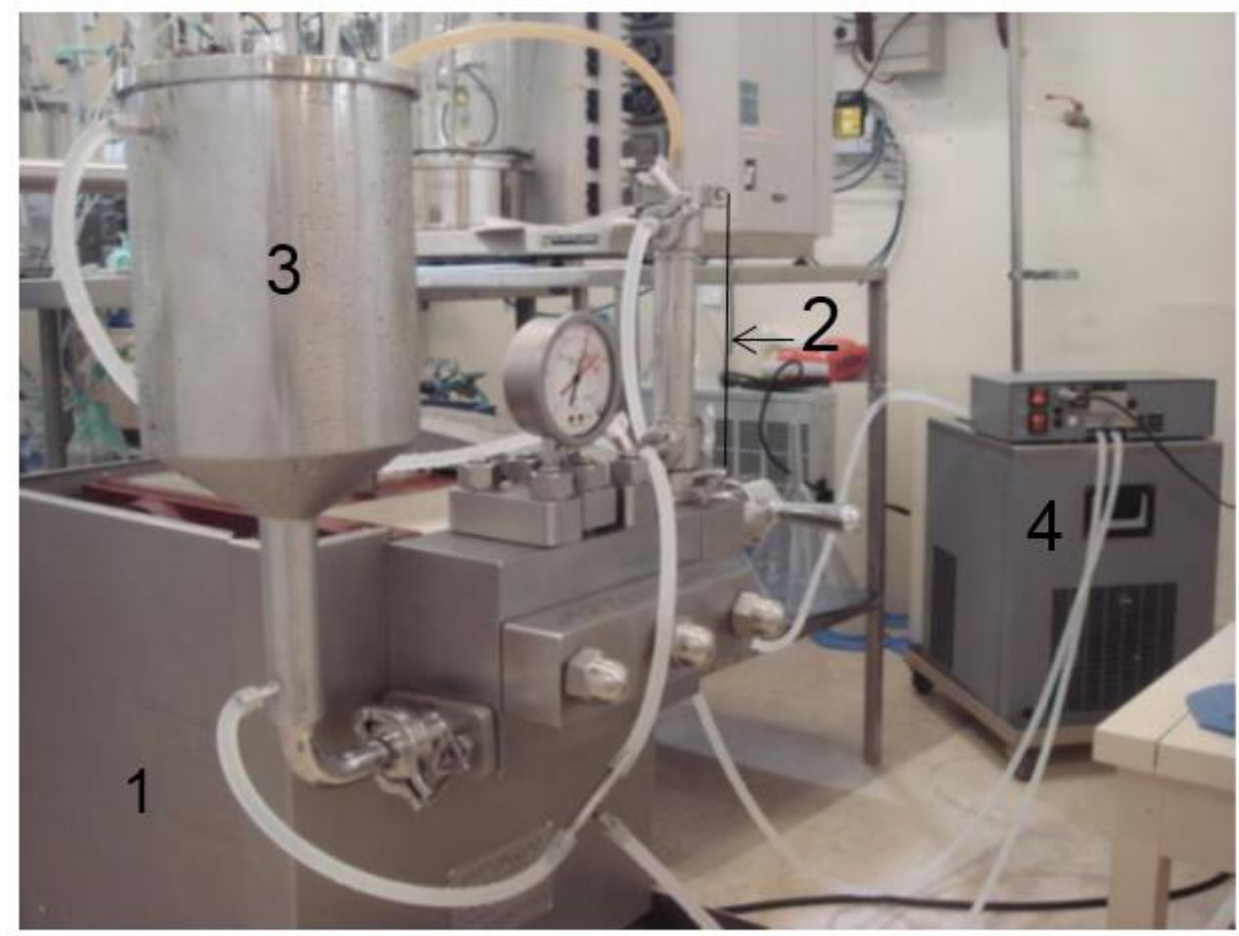

Legenda: 1) Homogeneizador contínuo de alta pressão APV GAULIN; 2) Trocador de calor casco e tubo; 3) Funil encamisado; 4) Recirculador de fluído de refrigeração

Para a clarificação foi empregado o detergente catiônico (CTAB) como auxiliar de precipitação a fim de facilitar a separação do material insolúvel por meio da formação de agregados de maior tamanho. O CTAB é usualmente utilizado na lise celular e na precipitação de polissacarídeos e ácidos nucleicos (Heinegård e Gardell, 1967; Lander et al., 2002; Tomanee et al., 2004) e em nosso laboratório já foram obtidos resultados promissores ao utilizarmos o CTAB para eliminar impurezas na etapa de clarificação (Figueiredo et al., 2017).

A concentração ótima de CTAB a ser adicionada foi determinada em testes visuais de leitosidade do sobrenadante de cada processo de purificação, sendo escolhida a maior concentração na qual o sobrenadante ainda permanece leitoso, pois resultados anteriores do laboratório mostraram que nessa concentração o CTAB 
precipita impurezas sem acarretar perdas significativas da proteína de interesse (Figueiredo, 2014).

Amostras de $10 \mathrm{~mL}$ de homogenato foram precipitadas com concentrações de CTAB de $0,05 \%$ a $0,5 \%$. Após adição da concentração ótima de CTAB ao homogenato e homogeneização por $1 \mathrm{~h}$, foi realizada centrifugação por $2 \mathrm{~h}$ a $4{ }^{\circ} \mathrm{C} \mathrm{e}$ $16.696 \mathrm{~g}$ e filtração a vácuo do sobrenadante com membrana de $0,45 \mu \mathrm{m}$. O clarificado, após estas etapas, está adequado a passar por colunas cromatográficas.

\subsubsection{Etapas cromatográficas}

Cromatografias de troca iônica (Q-Sepharose Fast Flow, GE HealthCare), interação hidrofóbica (Phenyl-Sepharose Fast Flow HighSub, GE HealthCare), afinidade por metal (IMAC-Sepharose 6 Fast Flow, GE HealthCare) e exclusão molecular (Superose 12, GE Healthcare) foram avaliadas de forma a maximizar o rendimento e a pureza do processo.

No processo de purificação 01 da PspA94-PdT a cromatografia de troca aniônica (Q-Sepharose) foi empregada como etapa de captura e a cromatografia de afinidade por metal (IMAC-Sepharose carregada com $\mathrm{Ni}^{2+}$ ) como etapa intermediária.

No processo de purificação 02 da PspA94-PdT também foi empregada cromatografia de troca aniônica (Q-Sepharose) como etapa de captura e cromatografia de interação hidrofóbica (Phenyl-Sepharose) como etapa intermediária.

No processo de purificação 03 da PspA94-PdT, além da cromatografia de troca aniônica, foram utilizadas a cromatografia de afinidade por metal como etapa cromatográfica intermediária (carregada com $\mathrm{Ni}^{2+}$ ) e cromatografia de exclusão molecular como etapa de polimento.

No processo de purificação 04 da PspA94-PdT, que foi feito seguindo as mesmas operações unitárias da purificação 03 , também foi testada paralelamente a cromatografia de afinidade por metal, porém agora carregada com íons $\mathrm{Co}^{2+}$. 
Para o processo de purificação da PspA94-RL-PdT foram utizadas as mesmas etapas cromatográficas da purificação 03 da PspA94-PdT, chamada neste trabalho de protocolo 2 .

Para os processos de purificação da PspA94-PdT e PspA94-RL-PdT destinadas às formulações vacinais utilizadas nos ensaios de imunização em camundongos, foi utilizado um protocolo simplificado descrito a seguir, chamado aqui de protocolo 1.

Na purificação simplificada, a biomassa úmida congelada foi ressuspensa em tampão de lise (conforme item 4.8.1.) sem EDTA. Para a lise foi utilizado sonicador por 4 períodos de 10 min cada, sendo que entre cada ciclo a biomassa era mantida no gelo por $30 \mathrm{~min}$. O ciclo conteve pulsos de $60 \mathrm{~Hz}$ por $1 \mathrm{~s}$, a cada $4 \mathrm{~s}$. Durante a lise o homogenato foi mantido a baixa temperatura por meio de imersão em gelo. Em seguida o homogenato foi centrifugado por 30 min a $4 \stackrel{\circ}{\mathrm{C}}$ e $16.696 \mathrm{~g}$.

$\mathrm{O}$ clarificado $\mathrm{pH}$ 7,5 foi então submetido à cromatografia de afinidade por íons níquel. Foi utilizada uma coluna pré empacotada de IMAC Sepharose de $5 \mathrm{~mL}$ (Hi Trap IMAC FF $5 \mathrm{~mL}$ ). A eluição foi realizada com gradiente de 20 a 300 mM de imidazol em 20 volumes de coluna e coletada em frações de 2,5 mL. A partir da análise do cromatograma e do SDS-PAGE das frações eluídas, foram definidas quais delas seriam unidas no pool. A concentração do híbrido e a sua pureza foram determinadas para todos os intermediários e para o pool das frações.

\subsubsection{Cromatografia de troca aniônica}

A cromatografia de troca aniônica foi realizada em coluna de $220 \mathrm{~mL}$. Para equilíbrio e re-equilíbrio foi usado tampão fostato $10 \mathrm{mM} \mathrm{pH} \mathrm{6,4} \mathrm{e} \mathrm{a} \mathrm{eluição} \mathrm{foi} \mathrm{feita}$ com concentrações crescentes de $\mathrm{NaCl}$ em degraus de 100 mM (100, 200, 300, 400 e $500 \mathrm{mM} \mathrm{NaCl}$ ), cada fração com volume equivalente a 5 volumes de coluna. Para limpeza foi utilizada solução de $\mathrm{NaCl} 1 \mathrm{M}$ e solução de $\mathrm{NaOH}$ 0,1 M. 


\subsubsection{Cromatografia de afinidade por metal}

Foram utilizadas colunas de afinidade por metal de $200 \mathrm{~mL}, 40 \mathrm{~mL}$ e $5 \mathrm{~mL}$ dependendo da quantidade de proteína a ser purificada. Nesta cromatografia, para equilíbrio e re-equilíbrio foi utilizado tampão fosfato $10 \mathrm{mM} \mathrm{pH} \mathrm{7,5} \mathrm{com} \mathrm{20mM} \mathrm{de}$ imidazol. A eluição foi feita com gradiente linear de imidazol de 20 a 300 mM, com volume equivalente a 20 volumes de coluna. $O$ volume de cada fração de eluição variou de 2 a $10 \mathrm{~mL}$, dependendo da quantidade de proteína a ser purificada e do tamanho da coluna utilizada. Também foi feita eluição isocrática com 5 volumes de coluna de $250 \mathrm{mM}$ de imidazol. Para limpeza foram utilizadas sequencialmente solução de imidazol 500 mM, solução de EDTA 200 mM e solução de $\mathrm{NaOH} 100$ mM.

\subsubsection{Cromatografia de interação hidrofóbica}

A coluna de interação hidrofóbica com volume de $150 \mathrm{~mL}$, foi equilibrada com

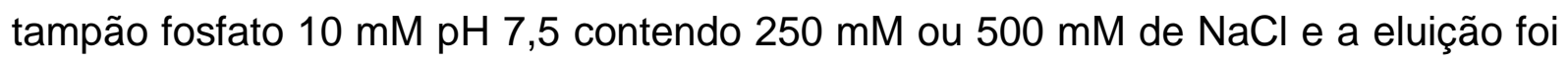
feita com degrau descrescente de $100 \mathrm{mM}$ de concentração de $\mathrm{NaCl}(400,300,200$, 100 e $0 \mathrm{mM} \mathrm{NaCl}$ ) seguido de dois degraus com concentração crescente de etanol (10 e 20\%); cada fração equivalente a 5 volumes de coluna. Também foi utilizada coluna de $20 \mathrm{~mL}$ de volume de leito, seguindo mesmos degraus de eluições. A limpeza foi feita com $\mathrm{NaOH} 100 \mathrm{mM}$.

\subsubsection{Cromatografia de exclusão molecular}

A cromatografia de exclusão molecular foi realizada em coluna de $100 \mathrm{~mL}$ de Superose 12. O volume de amostra injetado foi de $2 \mathrm{~mL}$ e a eluição com volume equivalente a 2 volumes de coluna foi coletada em frações de $3 \mathrm{~mL}$ ou manualmente em tampão fosfato $10 \mathrm{mM} \mathrm{pH} 8,0$ com $50 \mathrm{mM}$ de NaCl. A limpeza foi feita com $\mathrm{NaOH}$ $100 \mathrm{mM}$. 


\subsubsection{Análise dos processos de purificação}

O método de Lowry foi utilizado para determinar a concentração total de proteínas empregando albumina do soro bovino (BSA) como padrão.

Para a realização dos géis de eletroforese SDS-PAGE $10 \%$ todas as amostras foram diluídas de forma a se aplicar no gel 5 ou $10 \mu \mathrm{g}$ de proteínas totais em $15 \mu \mathrm{L}$. Às amostras foi adicionado $5 \mu \mathrm{L}$ de tampão de amostra desnaturante $4 \mathrm{x}$ concentrado (Tampão Tris- $\mathrm{HCl} 120 \mathrm{mM} \mathrm{pH} \mathrm{6,8} \mathrm{contendo} \mathrm{0,4 \%} \mathrm{SDS,} \mathrm{20 \%} \mathrm{glicerol,} \mathrm{8 \%}$ betamercaptoetanol e azul de bromofenol). A eletroforese foi realizada em tampão de corrida (Tampão Tris-base $50 \mathrm{mM} \mathrm{pH} \mathrm{8,3} \mathrm{contendo} \mathrm{0,19} \mathrm{M} \mathrm{glicina} \mathrm{e} \mathrm{0,1 \%} \mathrm{SDS)} \mathrm{por}$ $80 \mathrm{~min}$ a $120 \mathrm{~V}$. Os géis foram corados em solução corante ( $25 \%$ etanol, $5 \%$ ácido acético e $0,1 \%$ Comassie Blue G-250) overnight e descorados com solução descorante por pelo menos $2 \mathrm{~h}$ (etanol $10 \%$ e ácido acético $5 \%$ ).

A pureza relativa das proteínas híbridas foi determinada por densitometria dos géis de SDS-PAGE (densitômetro BioRad modelo GS-800). Tabelas de purificação foram construídas para avaliar e orientar os processos contendo os seguintes parâmetros: proteína total por etapa, quantidade de proteína híbrida por etapa, recuperação global e por etapa, pureza relativa e fator de purificação global e por etapa.

\subsection{Avaliação da integridade das proteínas híbridas}

A integridade dos híbridos foi verificada por eletroforese (SDS-PAGE 10\%) e Western Blot das amostras logo após cada etapa da purificação e depois de mantidas a $4 \stackrel{\circ}{\circ} \mathrm{C}$ ou $-20^{\circ} \mathrm{C}$ em intervalos crescentes de tempo.

Para a realização de cada Western Blot foram feitos dois géis SDS-PAGE idênticos: um para prosseguir com a análise e outro como controle (corado com Comassie). As proteínas de um dos géis foram transferidas para membrana de nitrocelulose na presença de tampão Bjerrum Schafer-Nielsen (Tris 48 mM, glicina 39 $\mathrm{mM}$ e etanol $20 \% \mathrm{pH} 9,2$ ) em sistema semi-dry por 80 min e $20 \mathrm{~V}$. A membrana foi corada com solução corante (10\% ácido acético e 0,5\% Ponceau) para visualização da transferência e indicação com lápis das bandas do padrão de massa molecular. 
Em seguida a membrana foi incubada em solução de bloqueio (PBS com $5 \%$ leite desnatado) overnight. A incubação da membrana com anticorpo primário (soro anti célula inteira de pneumococo produzido em coelho diluído na proporção de 1/2000 em PBS com $5 \%$ de leite desnatado) foi feita por 60 min e então a membrana foi lavada 3 vezes por 10 min com a solução de bloqueio. $A$ incubação com anticorpo secundário (anti-IgG de coelho conjugado com peroxidase, Sigma Aldrich código A0545) também foi realizada por 60 min e a membrana foi lavada novamente por 3 vezes, 10 min cada, com solução de bloqueio e uma vez com água destilada. A peroxidase foi revelada com a solução de revelação (18 mL PBS, $10 \mathrm{mg}$ DAB (diaminobenzidina), $2 \mathrm{~mL} \mathrm{CoCl} 2$ $0,3 \%$ e $20 \mu \mathrm{L} \mathrm{H}_{2} \mathrm{O}_{2}$ ) e rapidamente enxaguada com água corrente.

Além do soro de coelho imunizado com extrato total de pneumococo, que contém anticorpos contra as duas proteínas nativas, foi feito Western Blot com anticorpos contra ambas as proteínas que constituem o híbrido, obtidos pela imunização de camundongos com cada uma das proteínas recombinantes isoladamente. Os soros anti-PspA94 e anti-PdT foram gentilmente cedidos pela Dra. Luciana Leite do Instituto Butantan e o soro anti célula inteira de pneumococo foi gentilmente cedido pelo $\mathrm{Dr}$. Richard Malley, Boston Children's Hospital, Boston, MA, EUA.

\subsection{Análise da influência de estabilizantes na integridade do híbrido}

Com base na literatura, foram escolhidos os seguintes estabilizadores de proteína para fazerem parte dos experimentos: trealose, glicerol e sacarose (Wang, 1999; Kaushik e Bhat, 2003; Ohtake e Wang, 2011).

A estabilidade a $4 \stackrel{\circ}{\circ} \mathrm{C}$ da proteína híbrida PspA94-RL-PdT $0,17 \mathrm{mg} / \mathrm{mL}$ com alto grau de pureza (95\%) em tampão fosfato $10 \mathrm{mM} \mathrm{pH} \mathrm{7,5} \mathrm{juntamente} \mathrm{com} \mathrm{os}$ estabilizantes foi analisada ao longo de tempo através de SDS-PAGE e Western Blotting. As seguintes concentrações de estabilizantes foram testadas: trealose 1 e 2 $\mathrm{M}$, sacarose 1 e $2 \mathrm{M}$ e glicerol 25 e $50 \%$. As estabilidades obtidas foram comparadas àquela avaliada anteriormente, sem estabilizantes. 


\subsection{Ensaios para detecção de atividade proteolítica}

Para investigarmos se a molécula híbrida sem espaçador estaria sofrendo ação de proteases, foram realizados ensaios de digestão de caseína, zimogramas e ensaios específicos para detecção de serino e metaloproteases.

O ensaio de digestão de caseína foi efetuado nas amostras da purificação utilizando-se como substrato solução de caseína $10 \mathrm{mg} / \mathrm{mL}$ em tampão tris $20 \mathrm{mM} \mathrm{pH}$ 8 contendo $0,02 \%$ de azida sódica. À $0,4 \mathrm{~mL}$ dessa solução foram adicionados $0,1 \mathrm{~mL}$ da amostra, em banho de gelo, e a reação incubada a $37^{\circ} \mathrm{C}$ por $48 \mathrm{~h}$. Para controle positivo foi empregada tripsina $0,5 \mathrm{mg} / \mathrm{mL}$ e para o controle negativo foi usada água destilada no lugar das amostras.

A caseína não hidrolisada foi precipitada com ácido tricloroacético (TCA) na concentração final de $10 \%$ e os tubos foram mantidos em gelo por 30 min e centrifugados por 10 min a 10.000 rpm. A absorbância do sobrenadante a 280 nm foi medida imediatamente (brancos) e após a incubação (Gonçalves et al., 2003).

Os zimogramas foram realizados em gel de poliacrilamida $12 \%$ polimerizados na presença de gelatina $0,1 \%$ ou caseína $0,1 \%$. Para controle positivo foi utilizada solução de tripsina $0,5 \mathrm{mg} / \mathrm{mL}$. As amostras foram preparadas em condições não desnaturantes e a eletroforese foi realizada por 90 min a 120 V. Após a corrida, o gel foi lavado 2 vezes por 30 min e mais 2 vezes por 10 min com Triton 2,5\% para remoção do SDS e incubado com tampão colagenase $(50 \mathrm{mM}$ Tris $\mathrm{HCl}, 0,2 \mathrm{M} \mathrm{NaCl}$ e $5 \mathrm{mM}$ $\mathrm{CaCl}_{2}, \mathrm{pH} 7,6$ ) por aproximadamente $18 \mathrm{~h}$ a $37^{\circ} \mathrm{C}$ (Fernández-Resa et al., 1995; Leber e Balkwill, 1997; Garbett et al., 1999; Vandooren et al., 2013). Após a incubação o gel foi corado e descorado da mesma forma que os géis de eletroforese SDS-PAGE, conforme descrito no item 4.5.6.

A caseína é usada há algumas décadas na detecção das mais diversas classes de proteases por ser estável, ter uma composição complexa e estrutura randômica (Reimerdes e Klostermeyer, 1976). Ela é capaz de detectar a atividade de duas principais classes de proteases presentes em Escherichia coli: metaloproteases e serinoproteases (Jones et al., 1997). Outros substratos também utilizados em ensaios para detecção de atividade proteolítica são o colágeno e seu derivado, a gelatina (Wolf e Wirth 1996; Leber e Balkwill, 1997). 
Também foram realizados testes específicos para detecção de serinoproteases e metaloproteases utilizando substratos cromogênicos sintéticos destinados a essa função. Estes ensaios foram realizados no Laboratório Imunopatologia sob orientação da Dra. Ana Maria Moura da Silva.

Para a detecção específica de serinoproteases foi utilizado o reagente $\mathrm{Na}$ Benzoyl-L-arginine 4-nitroanilide hydrochloride, ou simplesmente L-BAPNA (Hieng et al., 2004) como substrato, conforme descrito por Knittel et al. (2016). Este substrato foi preparado na concentração de $115 \mathrm{mM}$ em tampão Tris-HCl $50 \mathrm{mM} \mathrm{pH} \mathrm{7,5.} \mathrm{A}$ incubação do substrato com a amostra foi realizada em placas de 96 poços contendo:

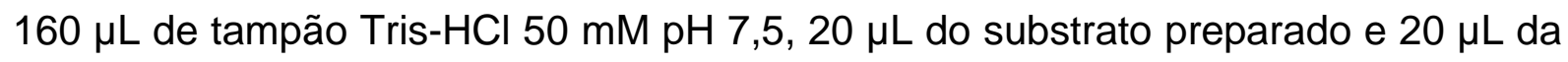
amostra, em diferentes concentrações (diluída no mesmo tampão) por 40 min a $37^{\circ} \mathrm{C}$. Para o controle positivo foi utilizada uma amostra de veneno de B. jararaca ( $5 \mu \mathrm{g}$ por poço) e para o controle negativo foi utilizado tampão no lugar da amostra. Após a incubação foi determinada a absorbância das amostras a $405 \mathrm{~nm}$.

Para a detecção de metaloproteases foi utilizado como substrato o reagente AbzAGLA-EDDnp (Freitas-De-Sousa et al., 2017; Mancuso et al., 2017) na concetração final de $200 \mu \mathrm{g}$, segundo (Knittel et al., 2016). Esse substrato foi diluído antes do uso para $400 \mu \mathrm{M}$ em tampão Tris- $\mathrm{HCl} 50 \mathrm{mM}$ com CaCl $210 \mathrm{mM}, \mathrm{NaCl} 150 \mathrm{mM}$ e 0,05\% Brij 35, pH 7,5. A incubação do substrato com a amostra foi realizada em placas de 96 poços contendo: $50 \mu \mathrm{L}$ de substrato diluído e $50 \mu \mathrm{L}$ da amostra, em diferentes concentrações. A absorbância foi monitorada por $10 \mathrm{~min}$, com medições de 1 em 1 min em comprimentos de onda de 320 e $420 \mathrm{~nm}$. Para o controle positivo foi utilizado

$50 \mu \mathrm{L}$ contendo $0,25 \mu \mathrm{g}$ de jararagina isolada de veneno de $B$. jararaca e para 0 controle negativo foi utilizado tampão no lugar da amostra.

\subsection{Sequenciamento da porção N-terminal}

Para definir o local exato da degradação do híbrido sem espaçador, a PspA94PdT totalmente degradada foi submetida a uma cromatografia de afinidade por íons níquel nas mesmas condições descritas no item 4.8.2.2. Essa cromatografia permitiu separar os fragmentos $\mathrm{N}$-terminais que continham a cauda de histidinas, portanto se ligaram à resina, dos fragmentos $\mathrm{C}$-terminais. A porção $\mathrm{C}$-terminal da proteína híbrida 
sem espaçador, que não foi não adsorvida na IMAC, foi então submetida a cromatografia líquida de alta eficiência em uma coluna com fase estacionária butil (C4). Para equilíbrio da coluna foi utilizada solução de ácido trifluoroacético (TFA) $0,1 \%$ e a eluição foi feita com a mesma solução e gradiente de 0 a $100 \%$ de acetonitrila. A absorbância da eluição foi acompanhada em tempo real em cromatograma e o pico majoritário foi coletado manualmente.

A proteína pura correspondente ao pico coletado foi concentrada e teve sua porção N-terminal sequenciada através da metodologia de degradação de Edman. Essas análises foram feitas com o auxílio do Dr. Rafael Marques Porto do Laboratório de Bioquímica e Biofísica do Instituto Butantan.

\subsection{Ensaios de avaliação de resposta imunológica dos híbridos PspA94- PdT e PspA94-RL-PdT}

O Comitê de Ética em experimentação animal do Instituto Butantan (CEUAIB) aprovou todos os experimentos com animais contidos neste trabalho, conforme certificado número: 5739290116, anexo a este trabalho.

Para a formulação das doses vacinais, foram utilizados os híbridos PspA94-PdT e PspA94-RL-PdT produzidos e purificados em pequena escala empregando protocolo simplificado, típico de Biologia Molecular, definido no item 4.8.2. como protocolo 1 e outra preparação de PspA94-RL-PdT produzida em biorreator e purificada pelo método desenvolvido neste trabalho, definido no item 4.8.2 como protocolo 2. A quantidade de proteína híbrida das formulações foi determinada levando em consideração a sua pureza.

Camundongos BALB/c fêmeas com 6 a 8 semanas de idade provenientes da Faculdade de Medicina da Universidade de São Paulo (São Paulo, Brasil) foram separados em quatro grupos com 6 animais cada. Eles foram imunizados conforme protocolo descrito por Cibelly et al (2013) com 3 doses subcutâneas de $200 \mu \mathrm{L}$ contendo $20 \mu \mathrm{g}$ de proteína híbrida (PspA94-PdT protocolo 1, PspA94-RL-PdT protocolo 1 ou PspA94-RL-PdT protocolo 2) com intervalos de 15 dias usando salina 
estéril $0,9 \%$ como veículo e $50 \mu \mathrm{g}$ de $\mathrm{Al}(\mathrm{OH})_{3}$ por animal como adjuvante. Para o grupo controle foi usado somente a salina $0,9 \%$ estéril com o adjuvante.

Duas semanas após cada imunização os animais foram anestesiados com uma gota de hidrocloreto de proximetacaína aplicada no globo ocular e tiveram o sangue coletado por via retro-orbital. A produção de anticorpos foi avaliada através de ELISA. As amostras contendo o soro dos animais imunizados foram analisadas individualmente. $O$ grupo controle foi comparado com os demais e o grupo imunizado com a PspA94-PdT foi comparado com os grupos imunizados com PspA94-RL-PdT (protocolos 1 e 2) através de one way ANOVA e Teste de Tukey.

Quinze dias após a última imunização os animais foram anestesiados com $1 \mu \mathrm{g}$ de quetamina e $0,625 \mu \mathrm{g}$ de xilazina por animal e então desafiados com $3 \times 10^{5} \mathrm{CFU}$ de S. pneumoniae linhagem A66.1 via intranasal. Todos os animais foram monitorados por 10 dias e as diferenças entre as taxas de sobrevivência de cada grupo foram analisadas por teste de Log Rank. Os animais foram eutanaziados quando se tornaram letárgicos e ao final dos dez dias todos os animais sobreviventes foram eutanasiados com uma dose letal de $60 \mathrm{mg} / \mathrm{kg}$ de xilazina e $300 \mathrm{mg} / \mathrm{kg}$ de quetamina.

Para as análises foi utilizado o software GraphPad Prism 6. Valores de $p>0,05$ foram considerados estatisticamente significativos

\subsection{Avaliação da capacidade de inibição da atividade hemolítica de Ply pelo soro dos animais imunizados com os híbridos}

Para avaliar a capacidade do soro dos animais imunizados com proteínas híbridas PspA94-PdT e PspA94-RL-PdT de inibir a atividade hemolítica da pneumolisina recombinante ativa ( $\mathrm{rPly}$ ), foram feitos ensaios de incubação de rPly com o soro dos animais e posterior adição de hemácias de carneiro. A rPly utilizada neste ensaio foi gentilmente cedida pela Dra. Cibelly Goulart, do Laboratório de Biotecnologia Molecular IV do Centro de Biotecnologia do Instituto Butantan.

Aproximadamente $8 \mathrm{UH}$ (unidades hemolíticas) de rPly foram incubadas juntamente com diferentes diluições do soro dos animais imunizados com os híbridos (diluições de 20 até 80 vezes - em duplicata) em volume final de $50 \mu \mathrm{L}$ por 30 min a 
$37 \stackrel{\circ}{\mathrm{C}}$. Foram utilizadas placas de 96 poços de fundo cônico. Após o final da primeira incubação foi adicionado $50 \mu \mathrm{L}$ de hemácia de carneiro $2 \%$ a cada diluição e as placas foram então incubadas novamente por $30 \mathrm{~min}$ a $37^{\circ} \mathrm{C}$. Ao final da segunda incubação as placas foram centrifugadas a $450 \mathrm{~g}$ por $10 \mathrm{~min}$. $\mathrm{O}$ sobrenadante de cada poço foi transferido para outra placa e a absorbância foi medida a $540 \mathrm{~nm}$. Como controles do ensaio foram utilizados: a rPly incubada com PBS no lugar do soro e as hemácias incubadas com água, o que deve resultar em hemólise completa. Como controle negativo foi utilizado o soro incubado com PBS no lugar da rPly. A porcentagem de hemólise foi calculada em relação ao grupo controle, que recebeu salina e adjuvante, que foi considerado como $100 \%$.

As hemácias de carneiro $2 \%$ foram preparadas a partir de sangue de carneiro centrifugado (NewProv código 1189) e lavado por 3 vezes com PBS, até que o sobrenadante retirado fosse límpido. As hemácias foram então ressuspendidas em 10 $\mathrm{mL}$ de PBS. 


\section{RESULTADOS}

Os resultados apresentados no item 5.1 compreendem os experimentos realizados com a construção em E. coli M15 contendo o plasmídeo pQE-30/pspA94-pdT para obtenção da proteína híbrida sem espaçador. O clone foi cedido pelo Laboratório de Biotecnologia Molecular IV e cultivado em biorreator pela equipe do Departamento de Engenharia Química da UFSCar. Após o cultivo, as células foram separadas do caldo por centrifugação e armazenadas a $-80^{\circ} \mathrm{C}$ até o uso.

Os resultados apresentados nos itens 5.2 e 5.3 compreendem os experimentos que envolveram as construções para obtenção das proteínas híbridas com espaçador flexível e rígido, respectivamente. Finalmente, os resultados dos ensaios imunológicos serão mostrados no item 5.4 .

\subsection{Híbrido sem espaçador PspA94-PdT}

O ponto isoelétrico ( $\mathrm{pl}$ ) teórico desta construção é 5,4 (Protein Calculator, 2013) e sua massa molecular é de $94.382,7 \mathrm{~g} / \mathrm{mol}$ (Expasy, 2013b). A sequência da construção sem espaçador e a sua composição em termos de porcentagem de aminoácidos consta no Apêndice I.

\subsubsection{Purificação 1}

No processo de purificação 01, o tempo ótimo de lise foi de 6 min (Figura 14) e a concentração de CTAB escolhida para a etapa de precipitação de impurezas foi de 0,35\%. Essa escolha foi feita após 30 min do início da sedimentação do precipitado, porém verificou-se após $24 \mathrm{~h}$ de repouso que a concentração de CTAB mais conveniente seria a de $0,25 \%$. A partir desta observação notou-se que a velocidade de sedimentação do precipitado era baixa e, por isso, para definir a concentração ótima de CTAB seria necessário centrifugar as amostras para acelerar a sedimentação (Figura 15). 
Neste processo, após a clarificação foram realizadas etapas cromatográficas de troca aniônica (Q-Sepharose), onde a eluição foi feita com $\mathrm{NaCl} 200 \mathrm{mM}$ em tampão

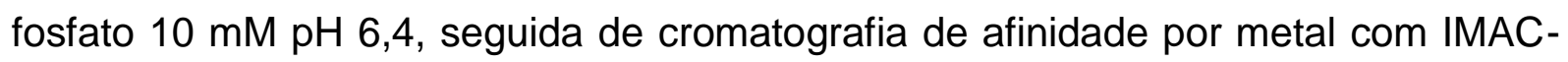
Sepharose carregada com níquel, onde a eluição foi realizada com solução imidazol $250 \mathrm{mM} \mathrm{em}$ tampão fosfato $10 \mathrm{mM} \mathrm{pH} \mathrm{7,5.} \mathrm{Resultados} \mathrm{anteriores} \mathrm{do} \mathrm{grupo} \mathrm{apontaram}$ a coluna Q-Sepharose como a melhor alternativa para a etapa cromatográfica de captura na purificação de PspA245, PspA3 e PspA4Pro (Barazzone et al., 2011; Carvalho et al., 2012; Figueiredo et al., 2017). Além de possuir maior capacidade, a resina Q-Sepharose é economicamente mais acessível e permite a eliminação de compostos que interferem na separação e diminuem a vida útil da resina de afinidade por metal, IMAC-Sepharose, que é mais onerosa.

Figura 14 - Lise das células (Abs 600nm) e liberação de proteínas (Abs 280nm) do processo de purificação 01

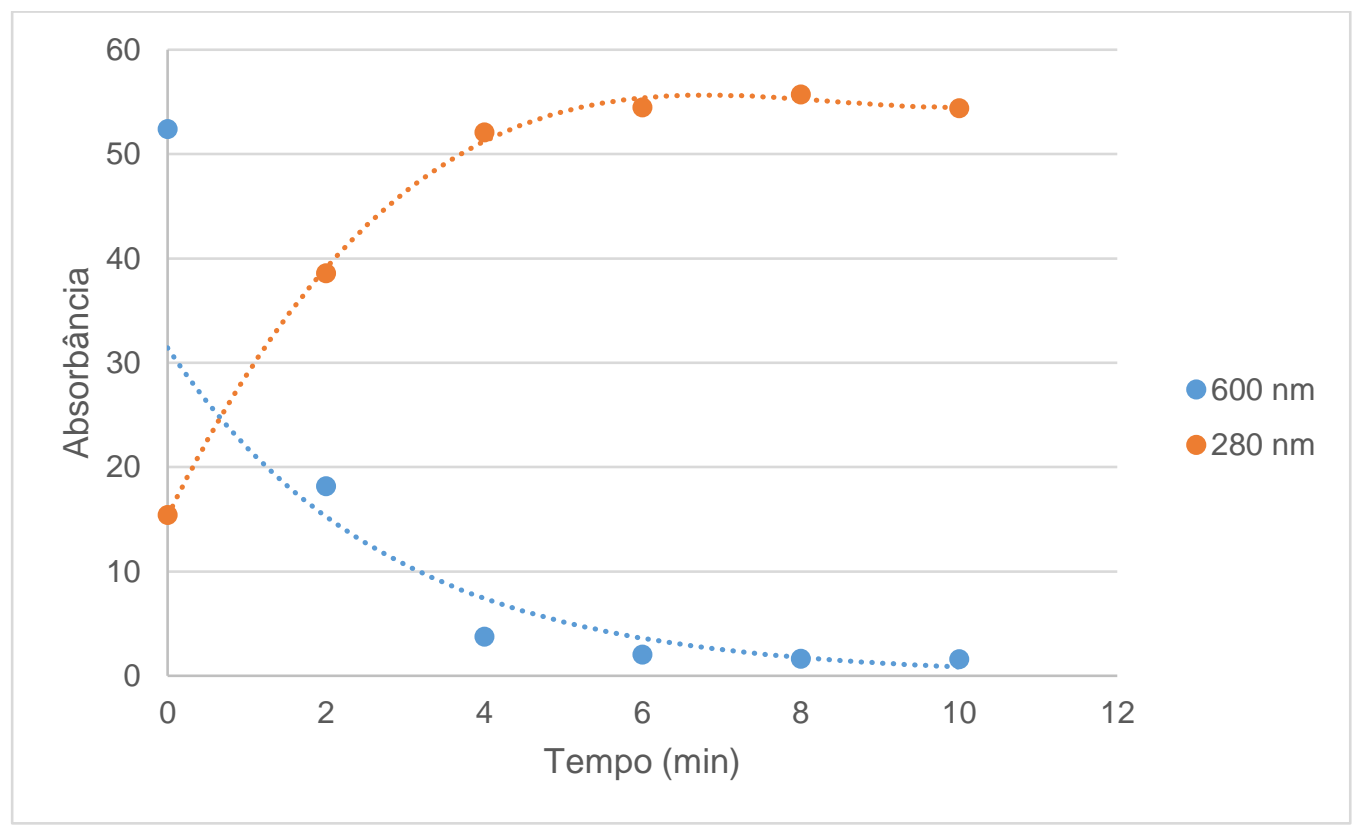


Figura 15 - Teste de precipitação de impurezas com CTAB do processo de purificação 01. A flecha indica da concentração de $0,25 \%$

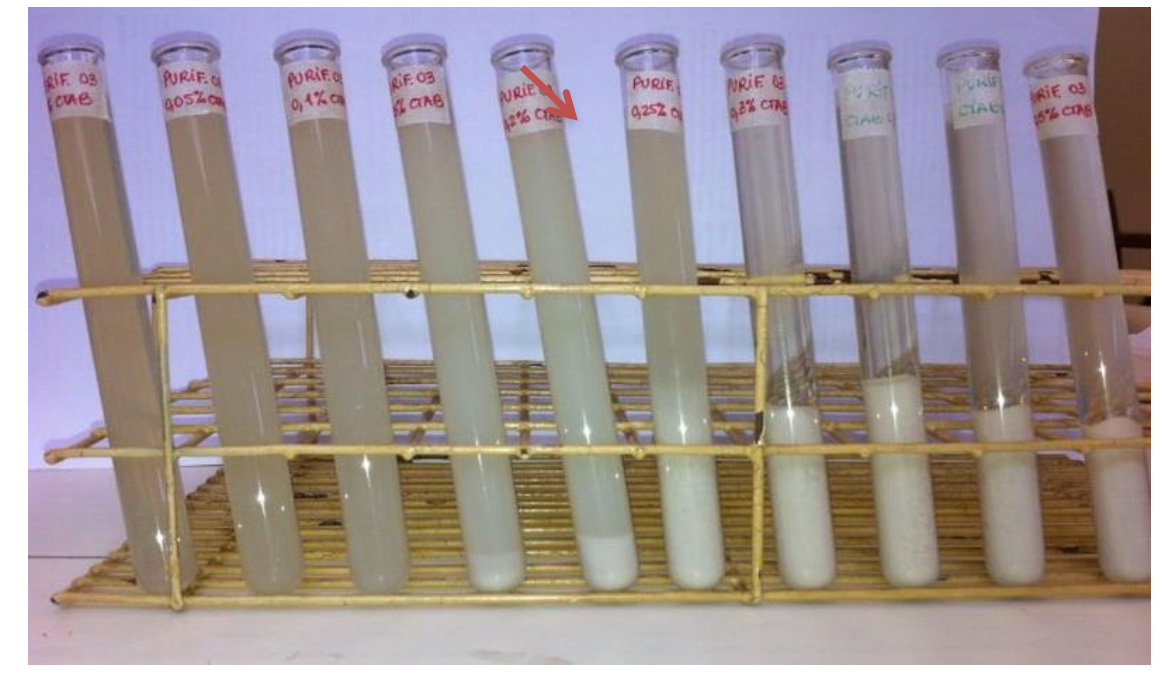

\begin{tabular}{c|c|c|c|c|c|c} 
Amostra & $\begin{array}{c}\text { Pureza } \\
\text { PspA94- } \\
\text { PdT (\%) }\end{array}$ & $\begin{array}{c}\text { PspA94- } \\
\text { PdT Total } \\
\text { (mg) }\end{array}$ & $\begin{array}{c}\text { Recuperação } \\
\text { PspA94-PdT } \\
\text { (Absoluta, \%) }\end{array}$ & $\begin{array}{c}\text { Recuperação } \\
\text { PspA94-PdT } \\
\text { (Etapa, \%) }\end{array}$ & $\begin{array}{c}\text { Fator de } \\
\text { Purificação } \\
\text { Absoluto }\end{array}$ & $\begin{array}{c}\text { Futor de } \\
\text { Purificação } \\
\text { Etapa }\end{array}$ \\
\hline Homogenato & 9,1 & 1363 & 100,0 & 100,0 & 1,0 & 1,0 \\
\hline $\begin{array}{c}\text { Clarificado } \\
\text { com 0,35\% } \\
\text { CTAB }\end{array}$ & 14,2 & 697 & 51,1 & 51,1 & 1,6 & 1,6 \\
\hline $\begin{array}{c}\text { F3 Q 200mM } \\
\text { NaCl }\end{array}$ & 48,5 & 473 & 34,7 & 67,9 & 5,3 & 3,4 \\
\hline $\begin{array}{c}\text { F3 IMAC } \\
\text { 250mM } \\
\text { imidazol }\end{array}$ & 86,2 & 122 & 8,9 & 25,8 & 9,5 & 1,8
\end{tabular}

Tabela 7 - Processo de purificação 01 PspA94-PdT

A eluição da Q-Sepharose foi aplicada numa coluna contendo IMAC-Sepharose e eluída em 250 mM de imidazol com 86,2\% de pureza. Além de a pureza final ficar aquém da desejada (Figura 16), a recuperação foi extremamente baixa (Tabela 7) quando comparada a processos desenvolvidos no laboratório para purificação de distintas PspA (Carvalho et al., 2012; Figueiredo et al., 2017). Por isso, fez-se 
necessário buscar otimizações que permitissem uma maior recuperação e maior pureza final.

Figura 16 - SDS-PAGE das amostras da purificação 01 da PspA-PdT

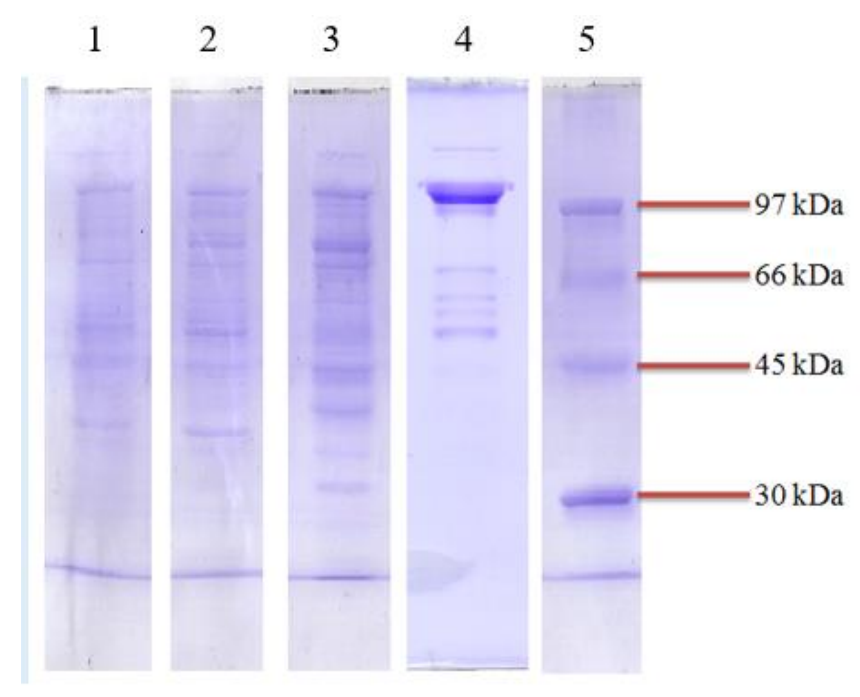

Legenda: 1. Homogenato (9,1\% de pureza), 2. clarificado com $0,25 \%$ CTAB (25,4\% de pureza), 3 . Eluição $200 \mathrm{mM} \mathrm{NaCl}$ Q-Sepharose (48,5\% de pureza), 4. Eluição $250 \mathrm{mM}$ imidazol IMAC-Sepharose (86,2\% de pureza), 5. Padrão de massa molecular

\subsubsection{Purificação 2}

No processo de purificação 02, o tempo ótimo de lise foi de 8 min (Figura 17) e a concentração de CTAB escolhida para a etapa de precipitação de impurezas foi de $0,10 \%$. Neste teste de precipitação de impurezas com CTAB, as amostras foram centrifugadas a 10.000 rpm por 20 min para acelerar a sedimentação antes do exame visual de leitosidade. Esta centrifugação permitiu uma escolha de concentração de CTAB consideravelmente menor que a escolhida para a purificação 01 , o que acarretou menores perdas da proteína alvo no clarificado, cuja recuperação de PspA94-PdT passou de 51,1\% (Tabela 7) para 72,3\% (Tabela 8).

$\mathrm{Na}$ tentativa de aumentar a recuperação e pureza neste processo, a cromatografia de afinidade, cuja recuperação foi baixa no processo anterior, foi substituída pela cromatografia de interação hidrofóbica. Desse modo seria possível aplicar a amostra eluída da Q-Sepharose com NaCl diretamente na coluna de PhenylSepharose e utilizar a IMAC-Sepharose como etapa final. 
Figura 17 - Lise das células (Abs 600nm) e liberação de proteínas (Abs 280nm) do processo de purificação 02

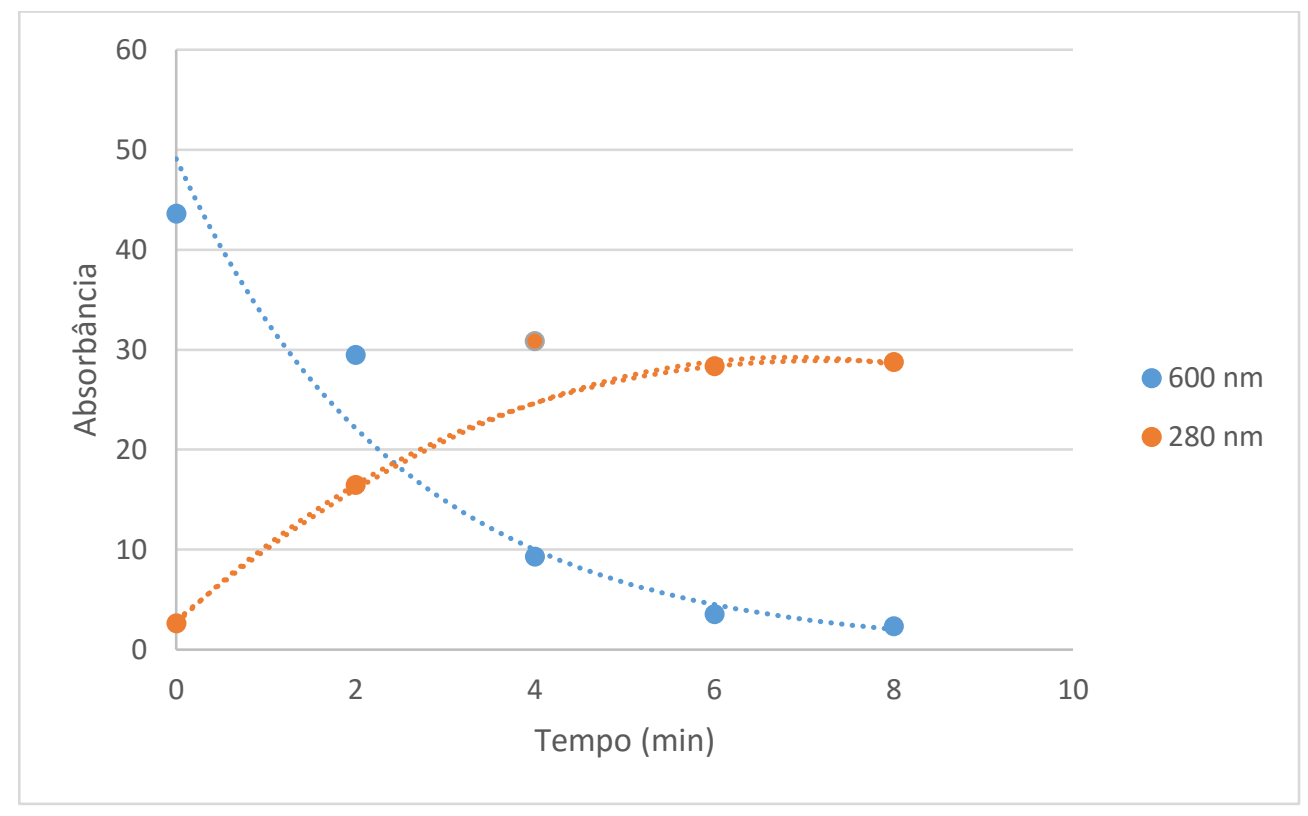

Entretanto, a recuperação das etapas cromatográficas deste processo também ficou muito aquém do esperado (Tabela 8), assim como no processo de purificação 01 (Tabela 7). Após a cromatografia de interação hidrofóbica ser realizada, a amostra foi mantida estéril a $4{ }^{\circ} \mathrm{C}$ enquanto as análises eram realizadas.

A Figura 18 apresenta 0 gel SDS-PAGE com amostras das etapas deste processo, bem como a pureza de PspA94-PdT de cada etapa.

Após as análises, antes de continuar o processo com a etapa de cromatografia de polimento, um novo gel SDS-PAGE foi feito e o perfil eletroforético observado nesse gel mudou drasticamente: onde antes se via uma única banda, agora se vêem várias bandas agrupadas em uma única região com aproximadamente metade do tamanho inicial (Figura 19). 


\begin{tabular}{c|c|c|c|c|c|c} 
Amostra & $\begin{array}{c}\text { Pureza } \\
\text { PspA94- } \\
\text { PdT (\%) }\end{array}$ & $\begin{array}{c}\text { PspA94- } \\
\text { PdT Total } \\
\text { (mg) }\end{array}$ & $\begin{array}{c}\text { Recuperação } \\
\text { PspA94-PdT } \\
\text { (Absoluta, \%) }\end{array}$ & $\begin{array}{c}\text { Recuperação } \\
\text { PspA94-PdT } \\
\text { (Etapa, \%) }\end{array}$ & $\begin{array}{c}\text { Fator de } \\
\text { Purificação } \\
\text { Absoluto }\end{array}$ & $\begin{array}{c}\text { Fator de } \\
\text { Purificação } \\
\text { Etapa }\end{array}$ \\
\hline Homogenato & 25,0 & 8536 & 100,0 & 100,0 & 1,0 & 1,0 \\
\hline $\begin{array}{c}\text { Clarificado } \\
\text { com 0,10\% } \\
\text { CTAB }\end{array}$ & 40,6 & 6171 & 72,3 & 72,3 & 1,6 & 1,6 \\
\hline $\begin{array}{c}\text { F3 Q 200mM } \\
\text { NaCl }\end{array}$ & 54,0 & 3015 & 48,7 & 67,4 & 2,2 & 1,3 \\
\hline $\begin{array}{c}\text { F2 Phenyl } \\
\mathbf{4 0 0 m M ~ N a C l}\end{array}$ & 85,5 & 127 & 3,6 & 7,4 & 3,4 & 1,8
\end{tabular}

Tabela 8 - Processo de purificação 02 PspA94-PdT

Figura 18 - SDS-PAGE das amostras da purificação 02 da PspA-PdT.

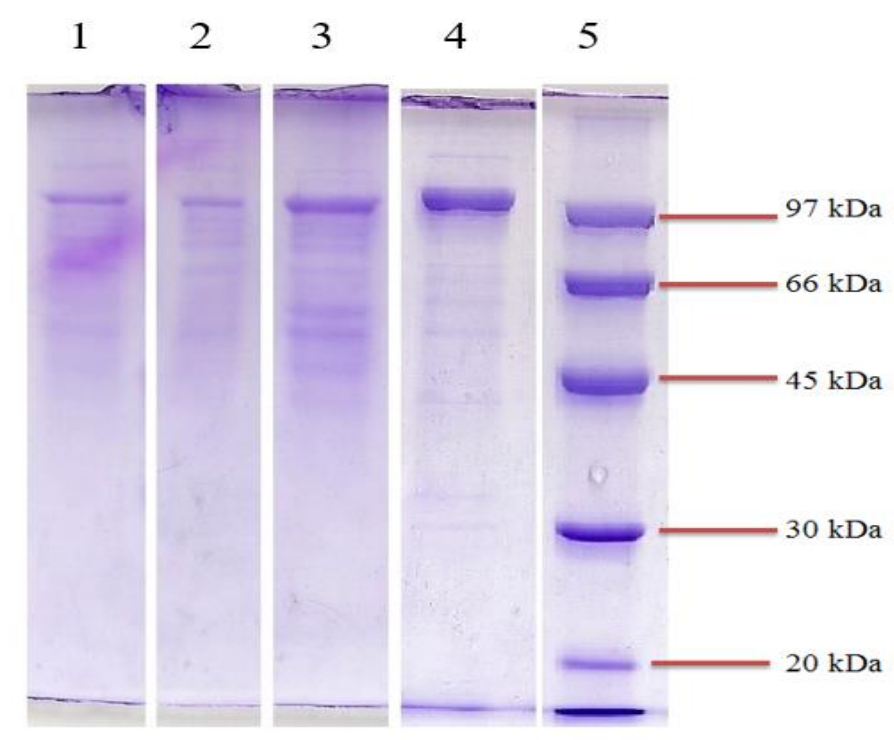

Legenda: 1. homogenato, 2. clarificado com 0,25\% CTAB (40,6\% de pureza), 3. Eluição $200 \mathrm{mM} \mathrm{NaCl}$ Q-Sepharose (54,0\% de pureza), 4. Eluição $400 \mathrm{mM} \mathrm{NaCl}$ Phneyl Sepharose (85,5\% de pureza), 5. Padrão de massa molecular 
Figura 19 - Mudança de perfil eletroforético da PspA-PdT purificada pelo processo 02 após 15 dias

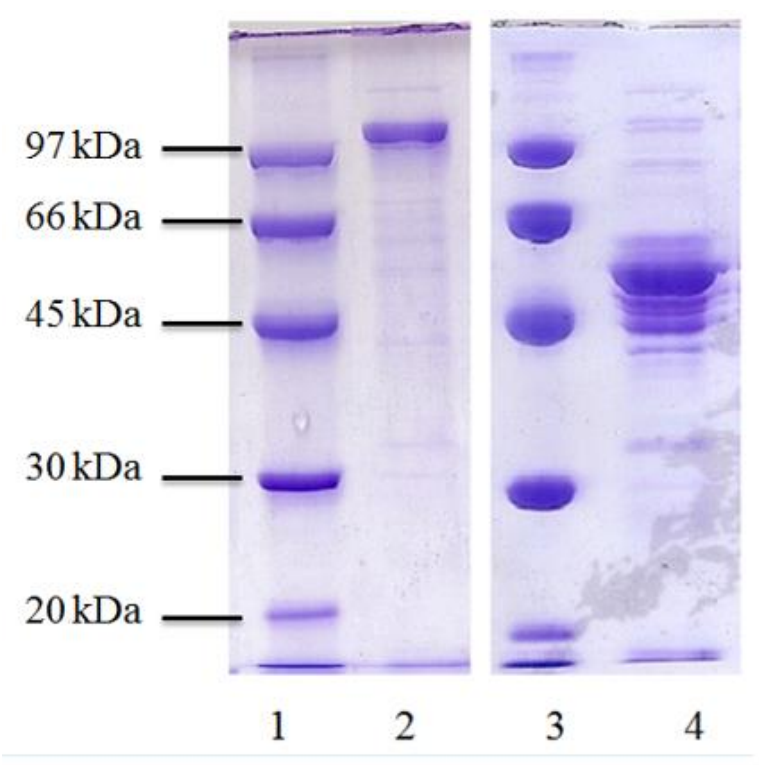

Legenda: 2. fração Phenyl F2 purificação 02 imediatamente após purificação e 4. mesma fração após armazenagem por 15 dias a $4^{\circ} .1$ e 3 . padrão de PM

\subsubsection{Ensaio de digestão de caseína}

Após a mudança drástica no perfil eletroforético da proteína parcialmente purificada, investigou-se a presença de proteases através de ensaio de digestão de caseína. Duas amostras eluídas da cromatografia hidrofóbica, Phenyl F2 (eluída com 400 mM NaCl) e F3 (eluída com 300 mM NaCl), provenientes deste processo de purificação 02 foram avaliadas quanto à presença de atividade proteolítica, e o resultado foi negativo para ambas, enquanto o controle positivo contendo tripsina apresentou elevada absorbância a $280 \mathrm{~nm}$ (Figura 20), indicando que apenas a tripsina foi capaz de hidrolisar a caseína e que as amostras não continham nenhuma protease capaz de hidrolisar caseína. 
Figura 20 - Ensaio de atividade proteolítica de amostras do processo de purificação 02

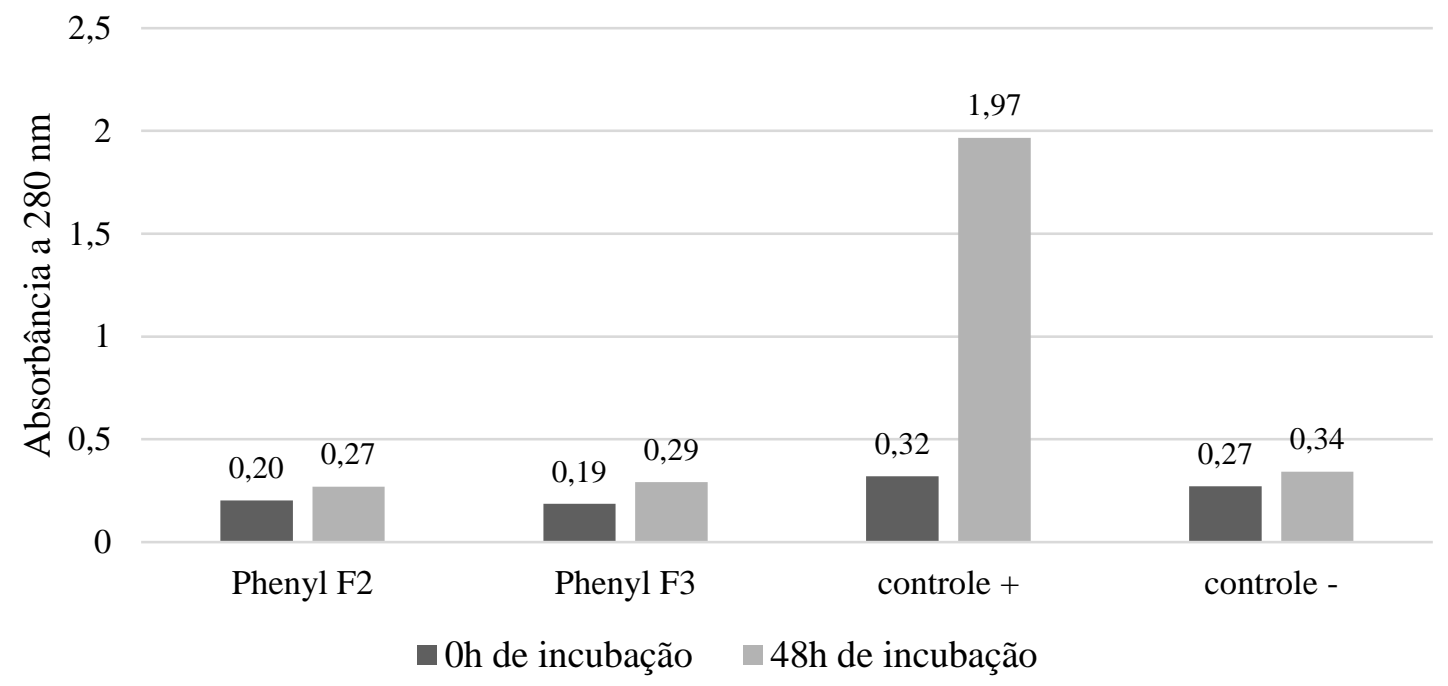

\subsubsection{Western Blot}

Uma vez que não foi encontrada atividade proteolítica nas amostras da purificação, procedeu-se com a análise da degradação da proteína híbrida por Western Blot. Apesar de o tamanho de ambas proteínas ser bem próximo em SDS-PAGE, a Figura 21 mostra que a fatia central da membrana, tratada com soro contra extrato total de pneumococo revelou as bandas da PspA94 e da PdT separadas uma da outra, ou seja, a proteína híbrida aparentemente está sofrendo quebra entre as duas moléculas unidas geneticamente nesta construção. A partir destes resultados, a hipótese de que a proteína estaria sendo degradada durante o processo de purificação passou a ser investigada. 
Figura 21 - Western-Blot da PspA-PdT degradada revelado com anti-PspA94, com antiextrato total de pneumococo e com anti-PdT
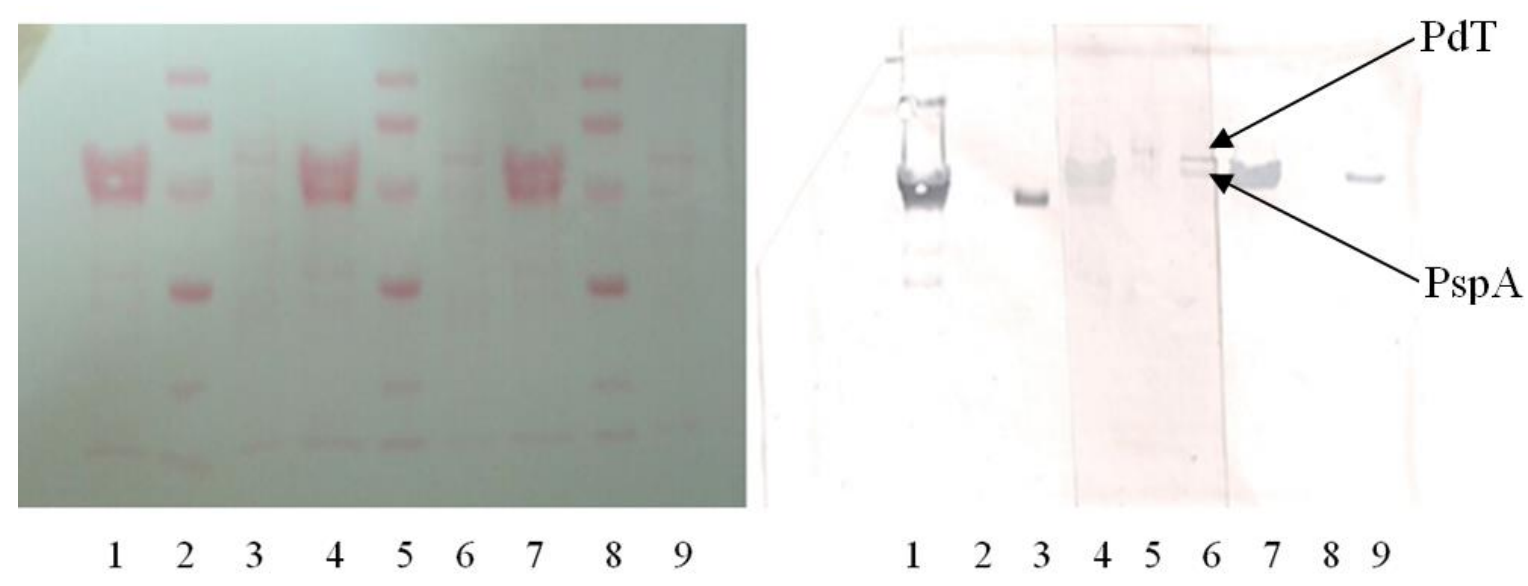

Legenda: Membrana de nitrocelulose corada com Ponceau (à esquerda) e Western Blot revelado com anti-PspA94 (canaletas 1-3), com anti-extrato total de pneumococo (canaletas 4-6) e com anti-PdT (canaletas 7-9). 1, 4 e 7: clarificado com $0,10 \%$ de CTAB; 2,5 e 8: padrão de massa molecular $(97,66$, 45, 30 e 20 kDa); 3, 6 e 9: eluição Phenyl F2

\subsubsection{Purificação 3}

No processo de purificação 03 o objetivo central foi aumentar a pureza da PspA94-PdT o máximo possível (se necessário em detrimento da recuperação) para que a hipótese de haver proteases responsáveis pela degaradação pudesse ser mais bem analisada. Nesta purificação, foram realizadas etapas cromatográficas de troca aniônica, afinidade por metal e exclusão molecular. As operações unitárias de purificação foram realizadas de forma a reduzir drasticamente o tempo do processo com o objetivo de obter o híbrido com um grau de pureza mais elevado.

Além disso, a composição do tampão de lise foi alterada para aumentar a concentração dos inibidores de proteases e assim inibir a ação de proteases que eventualmente não tivessem sido detectadas no ensaio de digestão da caseína e poderiam estar degradando a PspA94-PdT: a concentração de ambos os inibidores de proteases EDTA e PMSF foi aumentada de 1 para $5 \mathrm{mM}$. Nesta purificação, o tempo ótimo de lise foi de 8 min (Figura 22). A concentração de CTAB utilizada para a precipitação de impurezas foi de $0,1 \%$, já que o resultado anterior mostrou aumento de pureza de 1,6 vezes e $72,3 \%$ de recuperação com essa concentração (Tabela 8 ). 
Figura 22 - Lise das células (Abs 600nm) e liberação de proteínas (Abs 280nm) do processo de purificação 03

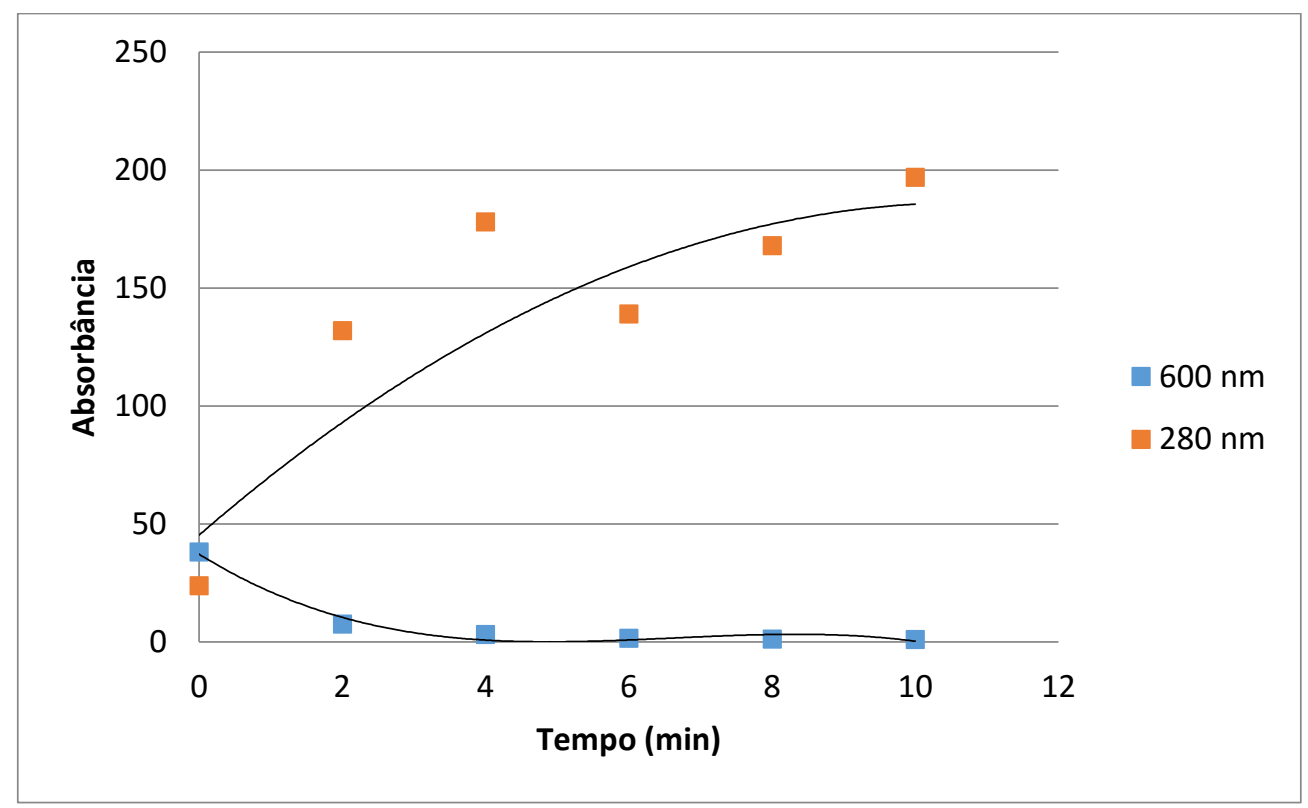

Para aumentar a eficiência das etapas cromatográficas posteriores à etapa de captura com Q-Sepharose, foram eluídas frações com auxílio do coletor de frações, de modo a possibilitar a escolha apenas dos tubos contendo a proteína com maior pureza para a etapa subsequente. A Tabela 9 de purificação deste processo é apresentada a seguir. A eluição com $200 \mathrm{mM}$ da Q-Sepharose foi aplicada em resina de afinidade IMAC-Sepharose carregada com íons $\mathrm{Ni}^{2+}$, e a eluição foi feita com gradiente de imidazol de 5 a $300 \mathrm{mM}$ e foram coletadas frações de $10 \mathrm{~mL}$. As frações do pico foram coletadas, e as duas com maior pureza e recuperação prosseguiram para as próximas etapas: a fração 2B4 com $85,2 \%$ de pureza e 5,1\% de recuperação seguiu para a coluna de exclusão molecular Superose 12 e a fração 2B5 com 76,8\% de pureza e $3,4 \%$ de recuperação seguiu para a coluna de interação hidrofóbica Phenyl-Sepharose. A cromatografia de exclusão molecular foi realizada em primeiro lugar, também utilizando o coletor de frações para coleta da eluição (frações de $3 \mathrm{~mL}$ ), mas a fração de eluição com a maior pureza, 1C3, apresentou pureza 5\% menor em relação à pureza da fração 2B4 que foi aplicada, passando de 85,2\% para 80,1\% (Tabela 9), o que sugere que esta etapa não foi eficiente e que a degradação da proteína está inviabilizando a sua purificação a um grau mais elevado. 
A fração 2B5 foi congelada para ser aplicada na coluna de interação hidrofóbica no dia seguinte. Ao descongelar a amostra, houve precipitação de grande parte da proteína. Foi feita uma tentativa de diminuir a concentração de proteína de 5,6 para $1,5 \mathrm{mg} / \mathrm{mL}$, que não acarretou mudança alguma. Também foi feito um teste de solubilização com arginina 0,5 M, $1 \mathrm{M}, 1,5 \mathrm{M}$ e $2 \mathrm{M}$ : na presença de arginina $2 \mathrm{M}$ a viscosidade e a leitosidade da fração diminuiram (análise visual), porém ainda restou uma quantidade considerável de proteínas precipitadas. Por fim, tentou-se solubilizar a proteína com uréia com posterior diálise gradual. Apesar de a solubilização completa da proteína ter acontecido na presença de 8M de uréia, a diálise gradual acabou por precipitar novamente a proteína da amostra. Essa precipitação da fração IMAC 2B5 inviabilizou seu carregamento na coluna de interação hidrofóbica. Este comportamento já havia sido observado anteriormente em processos de purificação da PspA4Pro quando a amostra era congelada com grau de pureza inferior a $50 \%$ (Figueiredo, 2014).

A Figura 23 apresenta o gel SDS-PAGE com amostras das etapas deste processo, bem como a pureza de PspA94-PdT de cada etapa.

\begin{tabular}{c|c|c|c|c|c|c} 
Amostra & $\begin{array}{c}\text { Pureza } \\
\text { PspA94 } \\
\text {-PdT } \\
\text { (\%) }\end{array}$ & $\begin{array}{c}\text { PspA94 } \\
\text {-PdT } \\
\text { Total } \\
\text { (mg) }\end{array}$ & $\begin{array}{c}\text { Recuperação } \\
\text { PspA94-PdT } \\
\text { (Absoluta, \%) }\end{array}$ & $\begin{array}{c}\text { Recuperação } \\
\text { PspA94-PdT } \\
\text { (Etapa, \%) }\end{array}$ & $\begin{array}{c}\text { Fator de } \\
\text { Purificação } \\
\text { Absoluto }\end{array}$ & $\begin{array}{c}\text { Fator de } \\
\text { Purificação } \\
\text { Etapa }\end{array}$ \\
\hline Homogenato & 5,3 & 10000 & 100,0 & 100,0 & 1,0 & 1,0 \\
\hline $\begin{array}{c}\text { Clarificado } \\
\text { com 0,10\% } \\
\text { CTAB }\end{array}$ & 12,5 & 8248 & 82,5 & 82,5 & 2,4 & 2,4 \\
\hline $\begin{array}{c}\text { F3 Q 200mM } \\
\text { NaCl }\end{array}$ & 32,8 & 1117 & 11,2 & 13,5 & 6,2 & 2,6 \\
\hline $\begin{array}{c}\text { Fração 2B4 } \\
\text { IMAC 250mM } \\
\text { imidazol }\end{array}$ & 85,2 & 57 & 0,6 & 5,1 & 16,1 & 2,6 \\
\hline $\begin{array}{c}\text { Fração 1C3 } \\
\text { Superose 12 }\end{array}$ & 80,1 & 4 & 0,04 & 6,7 & 15,1 & 0,9 \\
\hline
\end{tabular}

Tabela 9 - Processo de purificação 03 PspA94-PdT 
Figura 23 - SDS-PAGE das amostras da purificação 03

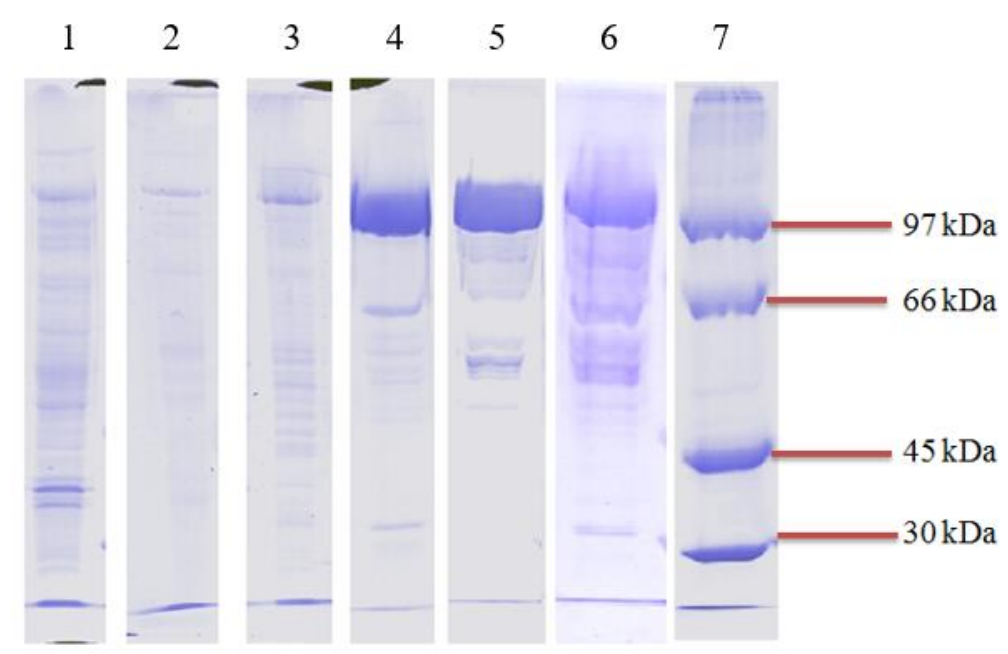

Legenda: 1. Homogenato (5,3\% de pureza), 2. clarificado com 0,1\% CTAB (12,5\% de pureza), 3. Eluição $200 \mathrm{mM} \mathrm{NaCl}$ Q-Sepharose (32,8\% de pureza), 4. Eluição fração 2B4 IMAC-Sepharose $(85,2 \%$ de pureza), 5 Eluição fração 2B5 IMAC-Sepharose (76,8\% de pureza), 6. Eluição Superose fração 1C3, 7. Padrão de massa molecular

\subsubsection{Western Blot}

Logo após a finalização do processo, amostras de eluição da Q-sepharose, IMAC-Sepharose e Superose 12 foram submetidas a um Western Blot para tentar identificar se nessas amostras já havia ocorrido degradação da PspA94-PdT. A análise do resultado apresentado na Figura 24 a seguir, permitiu observar que 0 anticorpo anti célula inteira de pneumococo não foi capaz de reconhecer nenhuma outra proteína com tamanho diferente da do híbrido PspA94-PdT. Isso indica que ao final da purificação a proteína encontrava-se íntegra nestas amostras, caso houvesse produtos de degradação, eles ainda não estariam em concentração suficiente para ser detectados no Western Blot. 
Figura 24 - Western Blot das eluições do processo de purificação 03

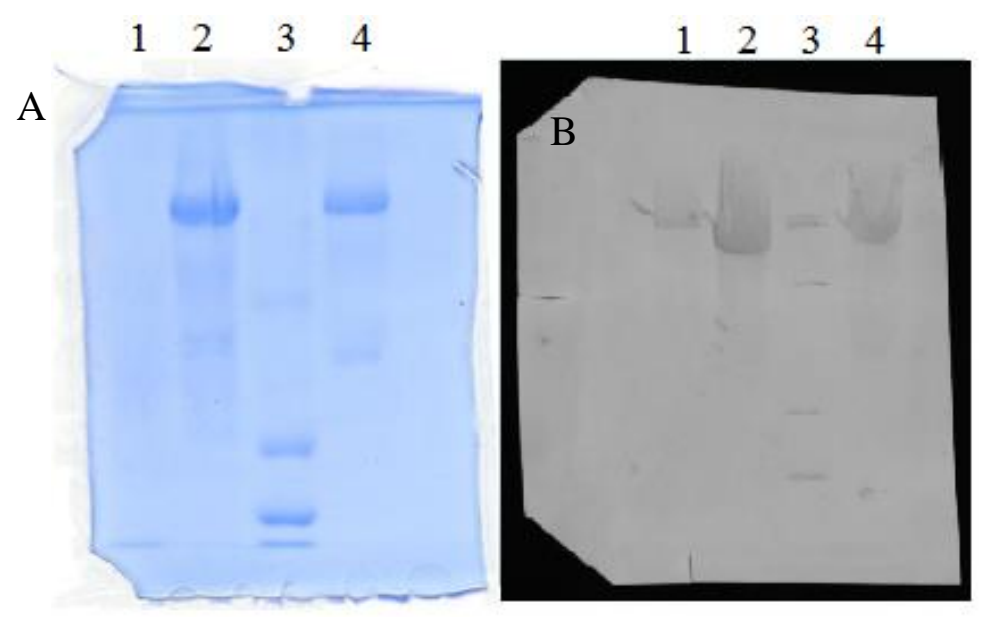

Legenda: A. Gel SDS-PAGE, B. Membrana revelada com anti célula inteira de pneumococo. 1. Eluição $200 \mathrm{mM} \mathrm{NaCl}$ Q-Sepharose, 2. Eluição fração 2B4 IMAC-Sepharose, 3. Padrão de massa molecular, 4. Eluição fração 1 C3 Superose.

As amostras da purificação foram mantidas a $-20^{\circ} \mathrm{C}$ por 14 semanas. Após esse período foi novamente possível visualizar a mudança no perfil eletroforético, indicando degradação parcial do híbrido, confirmada pelo Western Blot (Figura 25). É possível também observar que a armazenagem a $-20{ }^{\circ} \mathrm{C}$ diminuiu a taxa de degradação em relação às amostras da purificação 02 que foram mantidas a $4{ }^{\circ} \mathrm{C}$, mas não foi capaz de evitá-la por completo.

Apesar do aumento na concentração dos inibidores de proteases no tampão de lise desta purificação e da coleta apenas das frações com pureza mais elevada em todas as cromatografias que precederam a Q-Sepharose, não foi possível obter o híbrido com $>90 \%$ de pureza e ainda houve degradação da proteína durante o armazenamento. 
Figura 25 - Western Blot das eluições do processo de purificação 03 após 14 semanas a -20 $\stackrel{\circ}{C}$

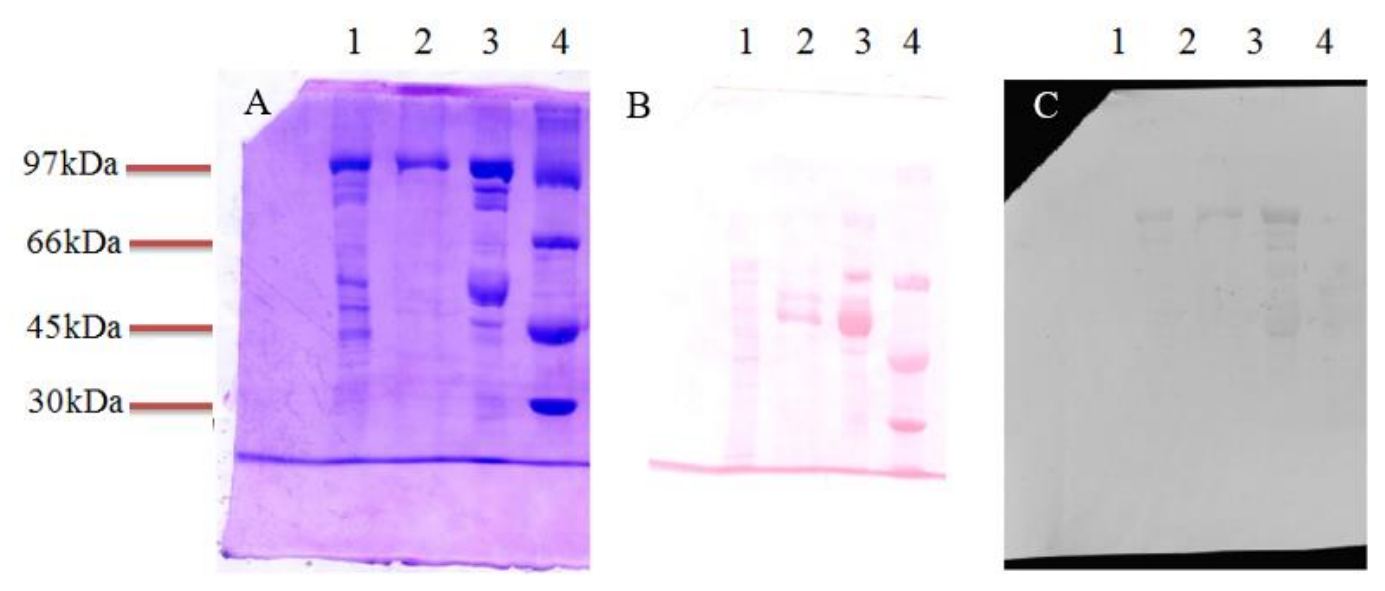

Legenda: A. Gel SDS-PAGE, B. Membrana de nitrocelulose corada com Ponceau, C. Membrana revelada com anti célula inteira de pneumococo. 1. Eluição $200 \mathrm{mM} \mathrm{NaCl} Q-S e p h a r o s e, 2$. Eluição fração 2B4 IMAC-Sepharose, 3. Eluição fração 1C3 Superose, 4. Padrão de massa molecular.

\subsubsection{Purificação 4}

No processo de purificação 04, a biomassa utilizada foi diferente dos processos anteriores, isto é, a biomassa foi obtida em um novo cultivo. Além disso, a composição do tampão de lise foi idêntica ao da purificação 03 e a concentração de CTAB utilizada para a precipitação de impurezas foi de $0,1 \%$. Esta purificação foi feita para tentar, assim como na purificação 3, alcançar elevado grau de pureza da PspA94-PdT.

Neste processo, o tempo ótimo de lise foi de $8 \mathrm{~min}$ (Figura 26). A eluição da cromatografia de troca aniônica foi dividida em duas frações de igual volume: uma foi aplicada em IMAC-Sepharose carregada com íons $\mathrm{Ni}^{2+}$ e a outra foi carregada com íons $\mathrm{Co}^{2+}$. A presença de íons cobalto garante uma maior especificidade por histidinas presentes na proteína e, por isso, esperava-se que a ligação de proteínas não específicas na resina fosse reduzida e a pureza da eluição desta etapa fosse aumentada.

Analisando a Tabela 10 do processo de purificação, é possível concluir que o carregamento da IMAC Sepharose com íons cobalto não melhorou a pureza da eluição em relação à mesma coluna carregada com íons níquel. Isso ocorreu porque a menor afinidade dos íons $\mathrm{Co}^{2+}$ por histidinas acarretou uma perda aproximadamente 
3 vezes maior da proteína de interesse no flowthrough (dados não mostrados), além de diminuir a recuperação pela metade (Tabelas 10 e 11). Além disso, é importante salientar que esta cromatografia foi feita 2 dias após a primeira cromatografia de afinidade com íons $\mathrm{Ni}^{2+}$, e durante este tempo ocorreu degradação da PspA94-PdT, pois a densitometria acusou para a mesma amostra, "Entrada IMAC", pureza de $48,2 \%$ na entrada da primeira cromatografia com íons $\mathrm{Ni}^{2+}$ e $33,3 \%$ na entrada da segunda cromatografia de afinidade com íons $\mathrm{Co}^{2+}$ (Tabelas 10 e 11).

Neste processo foi feita uma nova tentativa de purificar a fração eluída da IMAC-Sepharose carregada com íons $\mathrm{Ni}^{2+}$ na cromatografia de interação hidrofóbica, mas dessa vez a amostra não foi congelada para evitar a precipitação observada no processo 03 , mas sim imediatamente aplicada na coluna cromatográfica.

Analisando a pureza do híbrido ao longo do processo de purificação, percebese que a pureza do homogenato está maior do que a pureza do clarificado (Tabelas 10 e 11), o que poderia indicar que houve maior perda da proteína de interesse do que eliminação de impurezas, ou que tenha ocorrido um erro na medida de pureza do homogenato por densitometria, pois nessa fração ainda há muitas impurezas e algumas bandas poderiam estar sobrepostas no gel SDS-PAGE (Figura 27).

Figura 26 - Lise das células (Abs 600nm) e liberação de proteínas (Abs 280nm) do processo de purificação 04

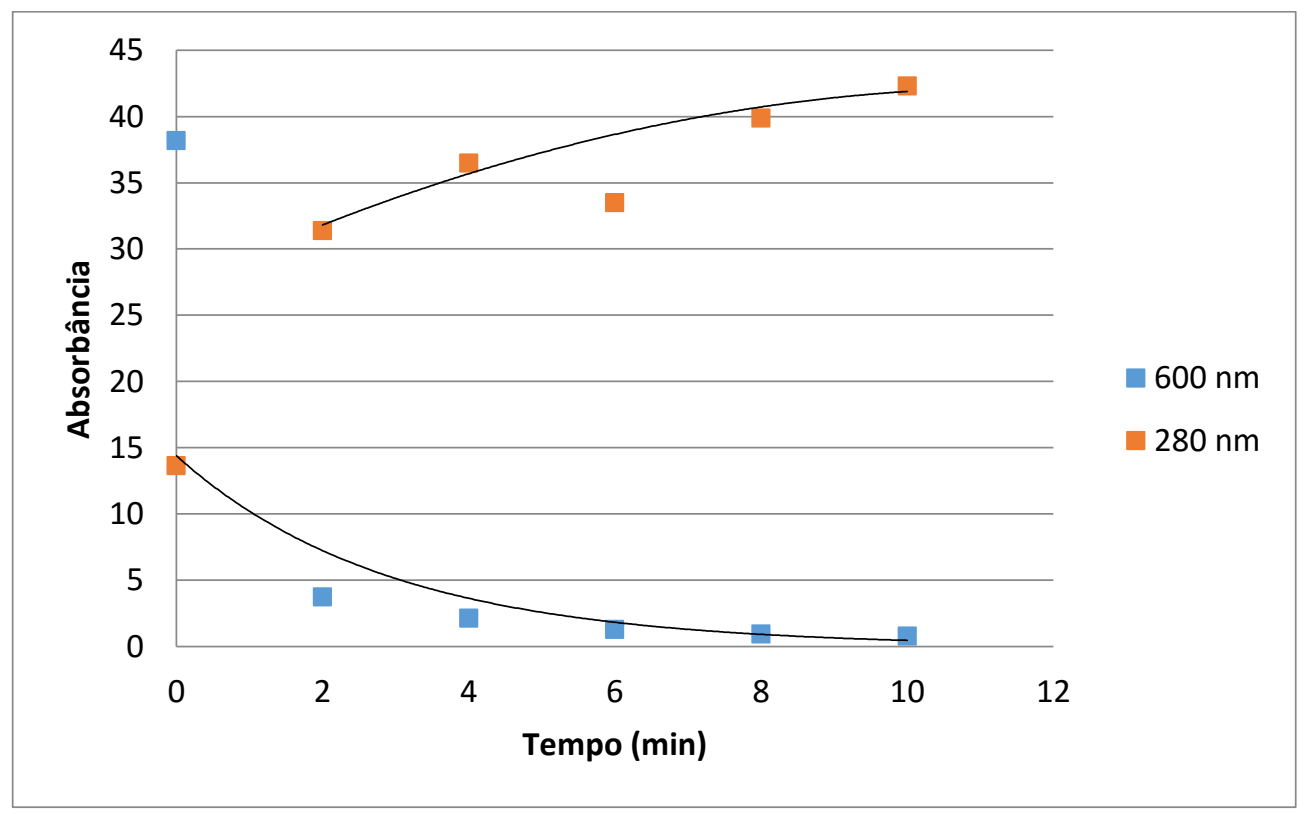




\begin{tabular}{|c|c|c|c|c|c|c|}
\hline Amostra & $\begin{array}{r}\text { Pureza } \\
\text { PspA94- } \\
\text { PdT (\%) }\end{array}$ & $\begin{array}{l}\text { PspA94- } \\
\text { PdT Total } \\
\text { (mg) }\end{array}$ & $\begin{array}{l}\text { Recuperação } \\
\text { PspA94-PdT } \\
\text { (Absoluta, \%) }\end{array}$ & $\begin{array}{c}\text { Recuperação } \\
\text { PspA94-PdT } \\
\text { (Etapa, \%) }\end{array}$ & $\begin{array}{c}\text { Fator de } \\
\text { Purificação } \\
\text { Absoluto }\end{array}$ & $\begin{array}{c}\text { Fator de } \\
\text { Purificação } \\
\text { Etapa }\end{array}$ \\
\hline Homogenato & 33,8 & 20169 & 100,0 & 100,0 & 1,0 & 1,0 \\
\hline $\begin{array}{c}\text { Clarificado } \\
\text { com } 0,10 \% \\
\text { CTAB }\end{array}$ & 27,3 & 16073 & 79,7 & 79,7 & 0,8 & 0,8 \\
\hline $\begin{array}{c}\text { F3 Q 200mM } \\
\mathrm{NaCl}\end{array}$ & 48,2 & 2862 & 14,2 & 17,8 & 1,4 & 1,8 \\
\hline $\begin{array}{l}\text { Entrada IMAC } \\
\mathrm{Ni}^{2+} \text { (Metade do } \\
\text { eluído da } \mathrm{Q} \text { ) }\end{array}$ & $48,2^{*}$ & 1431 & 7,1 & 8,9 & 1,4 & 1,8 \\
\hline $\begin{array}{c}\text { F3 IMAC Ni²+ } \\
250 \mathrm{mM} \\
\text { imidazol }\end{array}$ & 82,2 & 129 & 0,6 & 9,0 & 2,4 & 1,7 \\
\hline $\begin{array}{c}\text { F4 Phenyl 20\% } \\
\text { EtOH }\end{array}$ & 74,4 & 19 & 0,1 & 14,7 & 2,2 & 0,9 \\
\hline
\end{tabular}

Tabela 10 - Processo de purificação 04 PspA94-PdT utilizando IMAC carregada com íons $\mathrm{Ni}^{2+}$ * após a primeira determinação da pureza por densitometria

Após a cromatografia de afinidade com $\mathrm{Ni}^{2+}$, a pureza da proteína chegou a $82,2 \%$. Porém, a cromatografia de interação hidrofóbica acabou por diminuir a pureza da proteína alvo, que passou para $74,4 \%$. Novamente, a hipótese levantada é de que a proteína estaria degradando durante a purificação, o que impederia que se alcançasse um grau de pureza mais elevado ao final do processo. 


\begin{tabular}{c|c|c|c|c|c|c} 
Amostra & $\begin{array}{c}\text { Pureza } \\
\text { PspA94- } \\
\text { PdT (\%) }\end{array}$ & $\begin{array}{c}\text { PspA94- } \\
\text { PdT Total } \\
\text { (mg) }\end{array}$ & $\begin{array}{c}\text { Recuperação } \\
\text { PspA94-PdT } \\
\text { (Absoluta, \%) }\end{array}$ & $\begin{array}{c}\text { Recuperação } \\
\text { PspA94-PdT } \\
\text { (Etapa, \%) }\end{array}$ & $\begin{array}{c}\text { Fator de } \\
\text { Purificação } \\
\text { Absoluto }\end{array}$ & $\begin{array}{c}\text { Fator de } \\
\text { Purificação } \\
\text { Etapa }\end{array}$ \\
\hline Homogenato & 33,8 & 20169 & 100,0 & 100,0 & 1,0 & 1,0 \\
\hline $\begin{array}{c}\text { Clarificado } \\
\text { com 0,10\% } \\
\text { CTAB }\end{array}$ & 27,3 & 16073 & 79,7 & 79,7 & 0,8 & 0,8 \\
\hline $\begin{array}{c}\text { F3 Q 200mM } \\
\text { NaCI }\end{array}$ & 48,2 & 2862 & 14,2 & 17,8 & 1,4 & 1,8 \\
\hline $\begin{array}{c}\text { Entrada } \\
\text { IMAC Co2+ } \\
\text { (Metade do } \\
\text { volume } \\
\text { eluído da Q) }\end{array}$ & $33,3^{* *}$ & 989 & 4,9 & 34,5 & 1,0 & 1,2 \\
\hline $\begin{array}{c}\text { Pool teórico } \\
\text { frações do } \\
\text { pico (7 } \\
\text { frações) }\end{array}$ & 65,2 & 76 & 0,2 & & & \\
\hline $\begin{array}{c}\text { Fração 3A3 } \\
\text { IMAC + Co2+ }\end{array}$ & 68,3 & 6,0 & & & \\
\hline
\end{tabular}

Tabela 11 - Processo de purificação 04 PspA94-PdT utilizando IMAC carregada com íons $\mathrm{Co}^{2+}$

** após a segunda determinação da pureza por densitometria, feita em novo SDS-PAGE 
Figura 27 - SDS-PAGE das etapas do processo de purificação 04 da PspA-PdT.

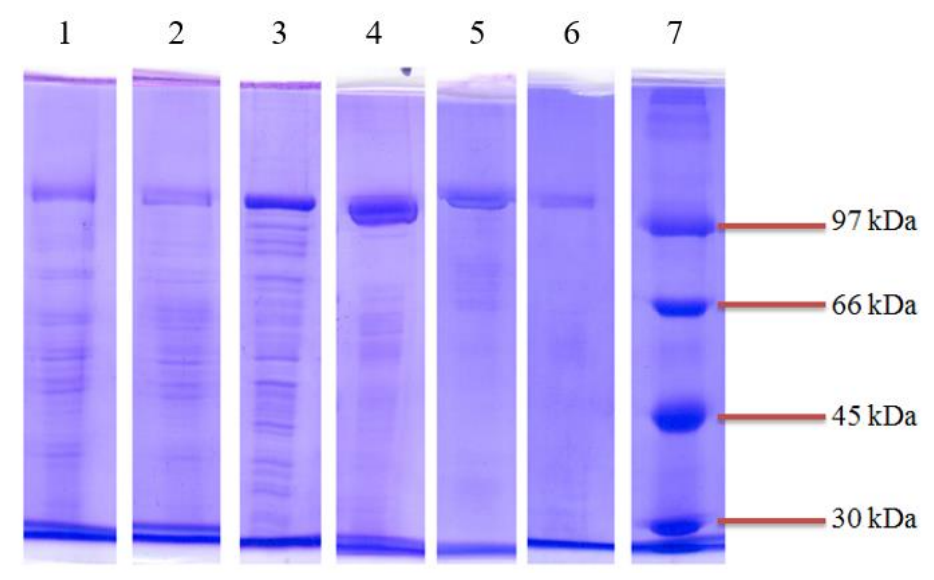

Legenda: 1. Homogenato (33,8\% de pureza), 2. clarificado com $0,1 \%$ CTAB (27,3\% de pureza), 3 . Eluição $200 \mathrm{mM} \mathrm{NaCl}$ Q-Sepharose (48,2\% de pureza), 4. Eluição $250 \mathrm{mM}$ imidazol IMAC-Sepharose carregada com Ni2+ (82,2\% de pureza), 5. Eluição fração 3A3 IMAC-Sepharose carregada com Co2+ (68,3\% de pureza), 6 . Eluição $20 \%$ Etanol Phenyl Sepharose (74,4\% de pureza), 7. Padrão de massa molecular

\subsubsection{Western Blot}

As amostras da purificação foram mantidas a $4{ }^{\circ} \mathrm{C}$ por 9 semanas e após esse período foi possível visualizar a mudança no perfil eletroforético da amostra do clarificado, indicando possível degradação parcial do híbrido, confirmada por Western Blot (Figura 28). A amostra eluída da cromatografia de interação hidrofóbica degradou e a intensidade das bandas da eletroforese ficou consideravelmente menor, sendo difícil a sua visualização em SDS-PAGE e Western Blot. 
Figura 28 - Western Blot de amostras da purificação 04 da PspA-PdT após 9 semanas a 4 $\stackrel{\circ}{\circ}$.

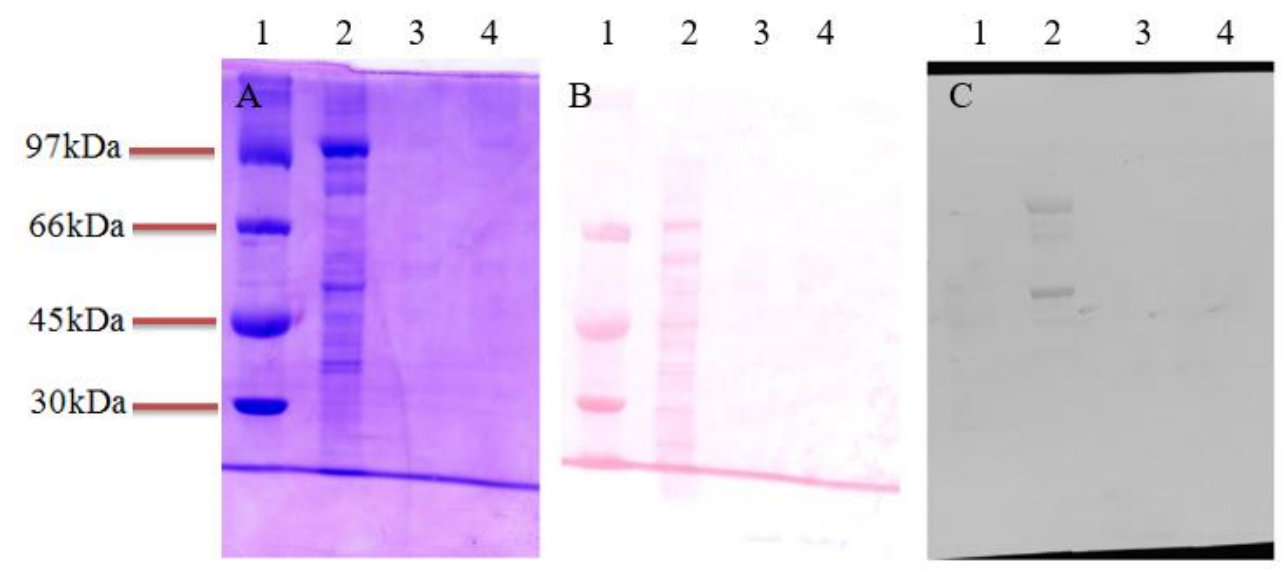

Legenda: A. Gel SDS-PAGE, B. Membrana de nitrocelulose corada com Ponceau, C. Membrana revelada com anti célula inteira de pneumococo. 1. Padrão de massa molecular, 2. Clarificado, 3. Eluição Phenyl Sepharose com Etanol 20\%, 4. Eluição Phenyl Sepharose com Etanol 20\% fervida por 10 min.

\subsubsection{Zimogramas}

A fim de aprofundar a investigação sobre a possível presença de proteases, foram realizados zimogramas com caseína e também com gelatina. Amostras do clarificado e da eluição da Phenyl Sepharose provenientes da purificação 4 foram avaliadas logo após o processo. Além disso, foi feita análise da eluição da Phenyl Sepharose após ser fervida por $10 \mathrm{~min}$. A Figura 29 apresenta o zimograma com gelatina $0,1 \%$ e a Figura 30 apresenta o zimograma com caseína 0,1\%.

Os zimogramas mostram que não há proteases nas amostras capazes de degradar nenhum dos substratos utilizados. 
Figura 29 - Zimograma com amostras da purificação 04 da PspA-PdT na presença de gelatina $0,1 \%$.

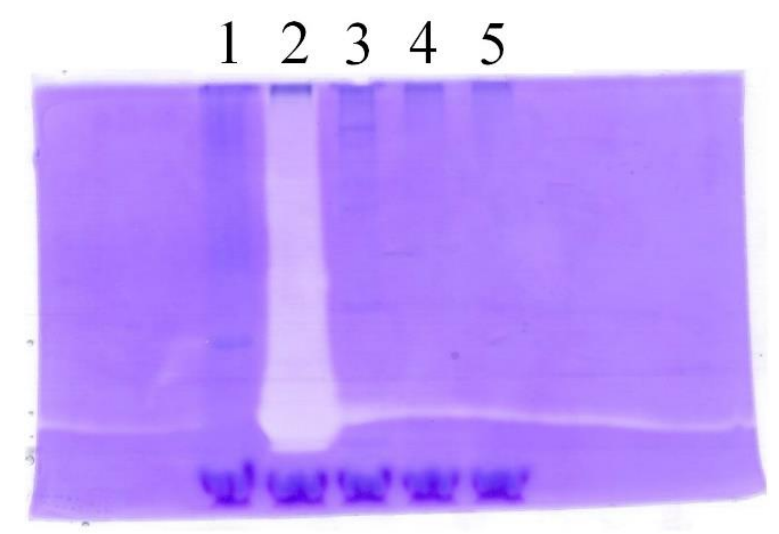

Legenda: 1. Padrão de massa molecular. 2. Controle positivo com $5 \mu \mathrm{g}$ de tripsina, 3. Clarificado Purificação 04, 4. Eluição Phenyl Sepharose Purificação 04, 5. Eluição Phenyl Sepharose Purificação 04 fervida por $10 \mathrm{~min}$.

Figura 30 - Zimograma com amostras da purificação 04 da PspA-PdT na presença de caseína $0,1 \%$.

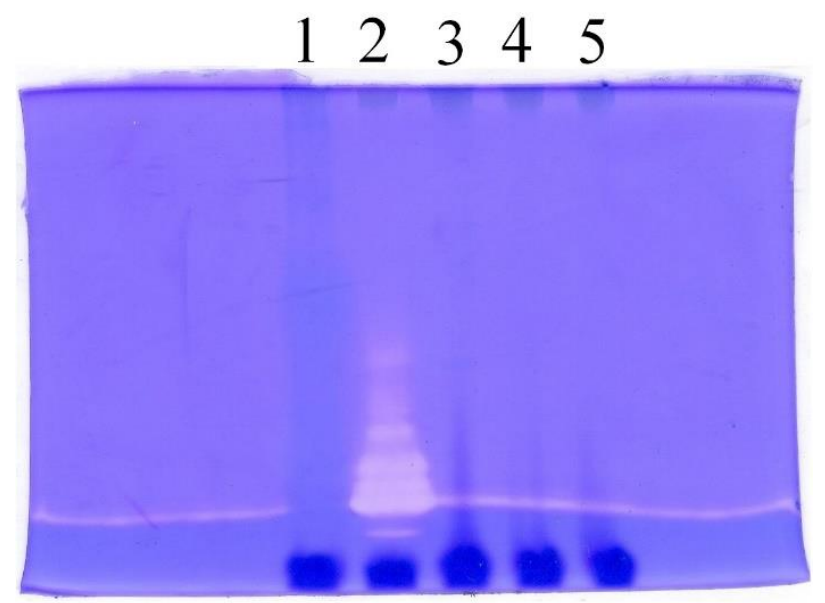

Legenda: Padrão de massa molecular. 2. Controle positivo com $1,7 \mu \mathrm{g}$ de tripsina, 3. Clarificado Purificação 04, 4. Eluição Phenyl Sepharose Purificação 05, 5. Eluição Phenyl Sepharose Purificação 05 fervida por $10 \mathrm{~min}$. 


\subsubsection{Ensaios específicos para detecção de serinoproteases e metaloproteases}

Para complementar a investigação de presença de atividade proteolítica, foram realizados ensaios no Laboratório de Imunopatologia do Instituto Butantan capazes de detectar especificamente serinoproteases e metaloproteases.

O ensaio para detecção de ambas as classes de proteases foi realizado utilizando duas amostras:

- Amostra 1: clarificado proveniente da purificação 3. Esta amostra ainda do início da purificação possui baixa pureza e mais contaminantes.

- Amostra 2: eluição da Q-Sepharose proveniente da purificação 2. Esta amostra mais pura que a anterior já continha a PspA94-PdT degradada.

No ensaio para detecção de serinoproteases, as amostras foram diluídas de forma seriada para uso no ensaio até o correspondente a 0,5, 0,05 e 0,005 $\mu \mathrm{g}$ de proteína por poço. $O$ gráfico com as absorbâncias obtidas após a incubação com o substrato L-BAPNA está apresentado na Figura 31A. As absorbâncias medidas não ultrapassaram $10 \%$ da absorbância do controle positivo.

Para checar se a diluição estava limitando a deteç̧ão das serinoproteases neste ensaio, ele foi repetido utilizando amostras 10 vezes mais concentradas. $O$ resultado deste segundo teste está apresentado na Figura 31B. As concentrações de amostra utilizadas foram de: $5,0,5$ e $0,05 \mu \mathrm{g}$ por poço. 
Figura 31 - Ensaio de detecção de serinoproteases com substrato L-BAPNA nas amostras de purificação da PspA94-PdT com veneno de B. jararaca como controle positivo.

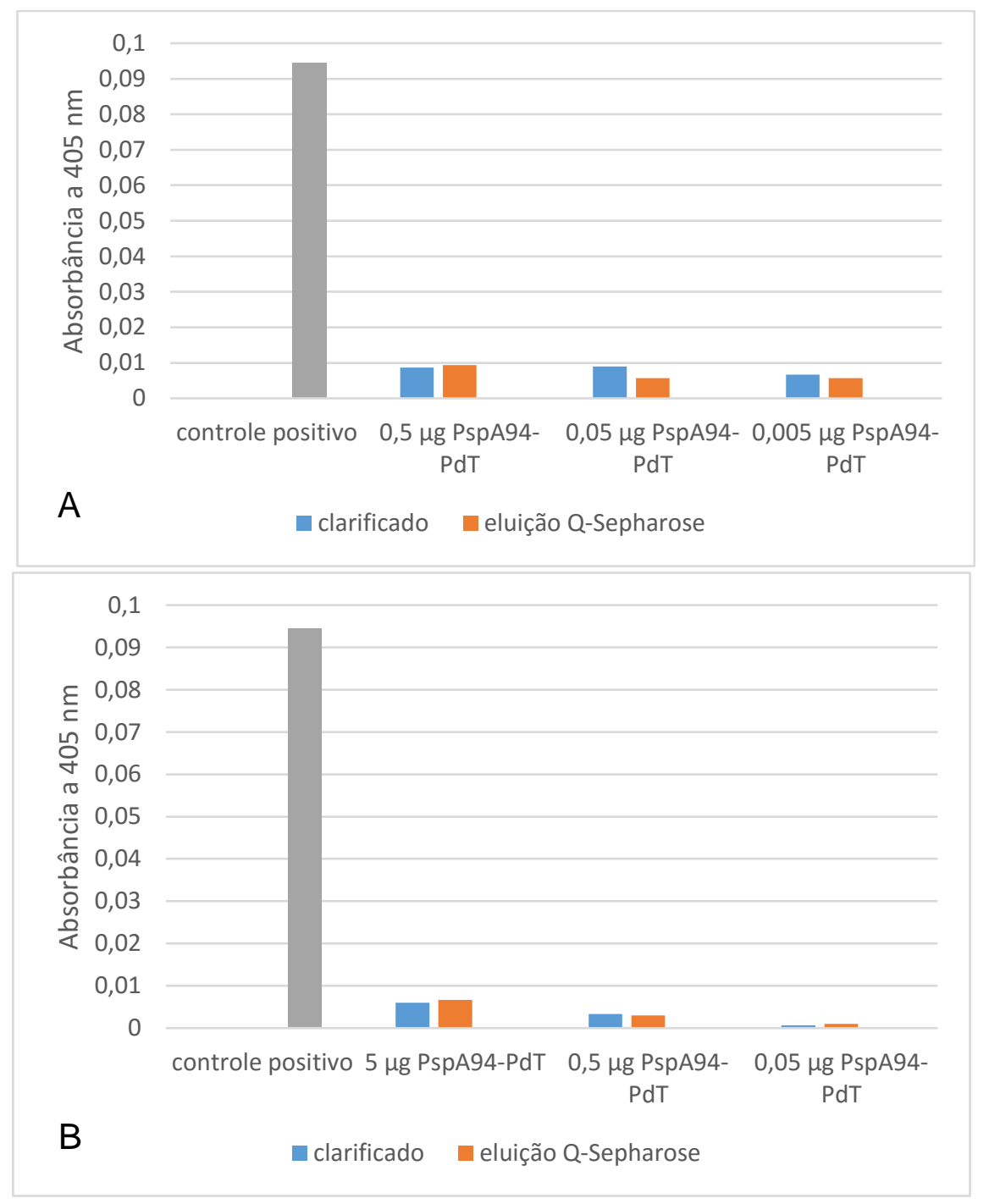

Legenda: A. Primeiro teste com menores quantidades de proteína por poço $(0,5,0,05$ e $0,005 \mu \mathrm{g})$ e B. Segundo teste com maiores quantidades de proteína por poço $(5,0,5$ e 0,05 $\mu \mathrm{g})$.

As absorbâncias medidas em todas as diluições continuaram não ultrapassando $10 \%$ da absorbância do controle positivo, indicando que este ensaio obteve resultado negativo para presença de serinoproteases.

O teste realizado para detecção de metaloproteases foi realizado utilizando as mesmas amostras nas mesmas diluições, correspondentes a: 5, 0,5 e 0,05 $\mu \mathrm{g}$ por poço. A Figura 32 apresenta o gráfico com as unidades relativas de fluorescência (RFU) medidas ao longo do tempo. Nele é possível observar a cinética da 
metaloprotease jararagina degradando o substrato linearmente ao longo do tempo (controle positivo). As amostras mantiveram suas RFUs entre -15 e 50 unidades, oscilando entre os pontos de medição. Com isso, conclui-se que não foi detectada atividade de metaloproteases nas amostras.

Figura 32 - Ensaio para detecção de metaloproteases com substrato Abz-AGLA-EDDnp nas amostras de purificação da PspA94-PdT com jararagina isolada como controle positivo.

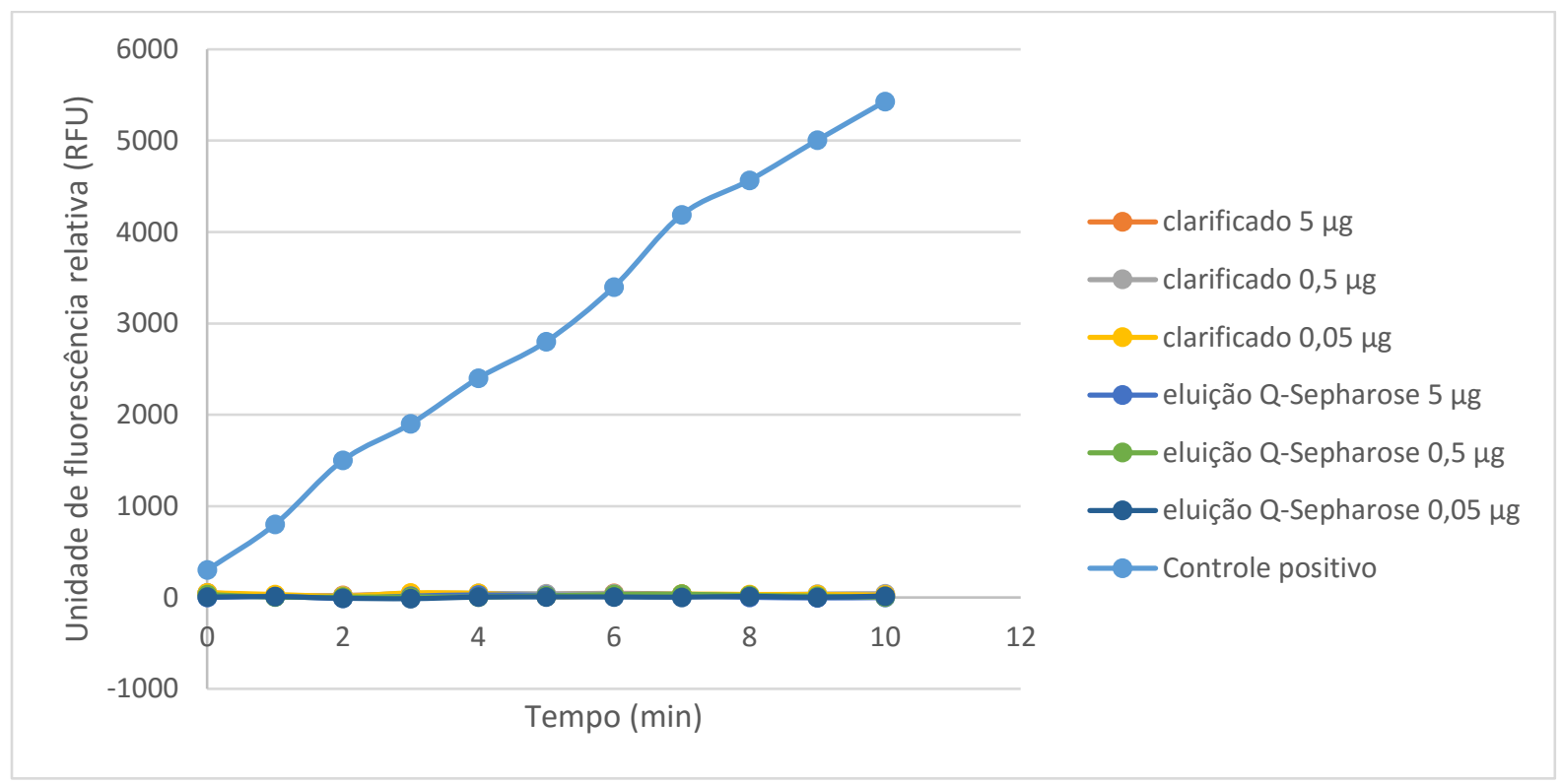

\subsubsection{Identificação do sítio de clivagem}

A proteína PspA94-PdT degradada teve seus fragmentos separados através de cromatografia de afinidade por metal nas mesmas condições descritas no item 4.5, utilizando uma coluna de IMAC-Sepharose carregada com íons $\mathrm{Ni}^{2+}$. Como este híbrido possui uma cauda de 6 histidinas na sua extremidade N-terminal, a porção Cterminal resultante da degradação foi coletada na fração não-adsorvida, enquanto a proteína íntegra eventualmente restante e a porção $\mathrm{N}$-terminal resultante da degradação foram recolhidas na fração de eluição com imidazol 250 mM.

A Figura 33 mostra o gel SDS-PAGE das amostras desta cromatografia. É possível perceber uma diferença sutil entre o tamanho dos fragmentos não-adsorvido e adsorvido na coluna. 
Figura 33 - Separação dos fragmentos da PspA94-PdT degradada por cromatografia de afinidade por metal

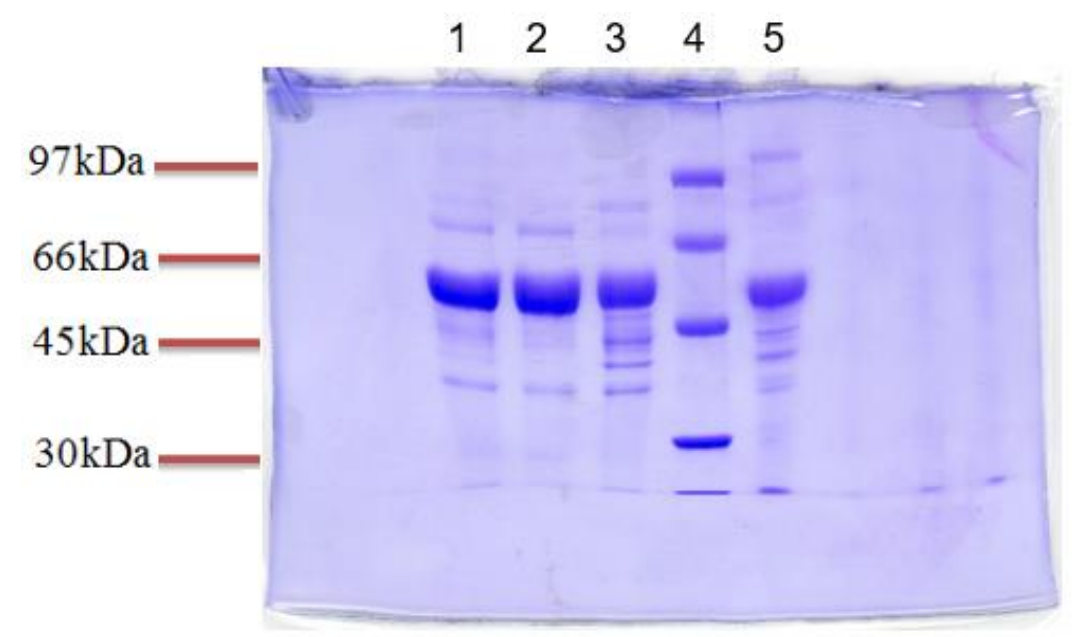

Legenda: 1. Entrada, 2. Fração não-adsorvida, 3. Re-equilíbrio da coluna, 4. Padrão de massa molecular, 5. Eluição 250 mM imidazol.

O cromatograma da Figura 34 representa a separação por HPLC do componente majoritário da fração não-adsorvida à IMAC-Sepharose, ou seja, correspondente a banda majoritária na canaleta 2 do SDS-PAGE da Figura 33.

Figura 34 - Cromatograma da purificação por HPLC em coluna C4 dos fragmentos da PspA94-PdT degradada obtidos na fração não adsorvida da IMAC-Sepharose.

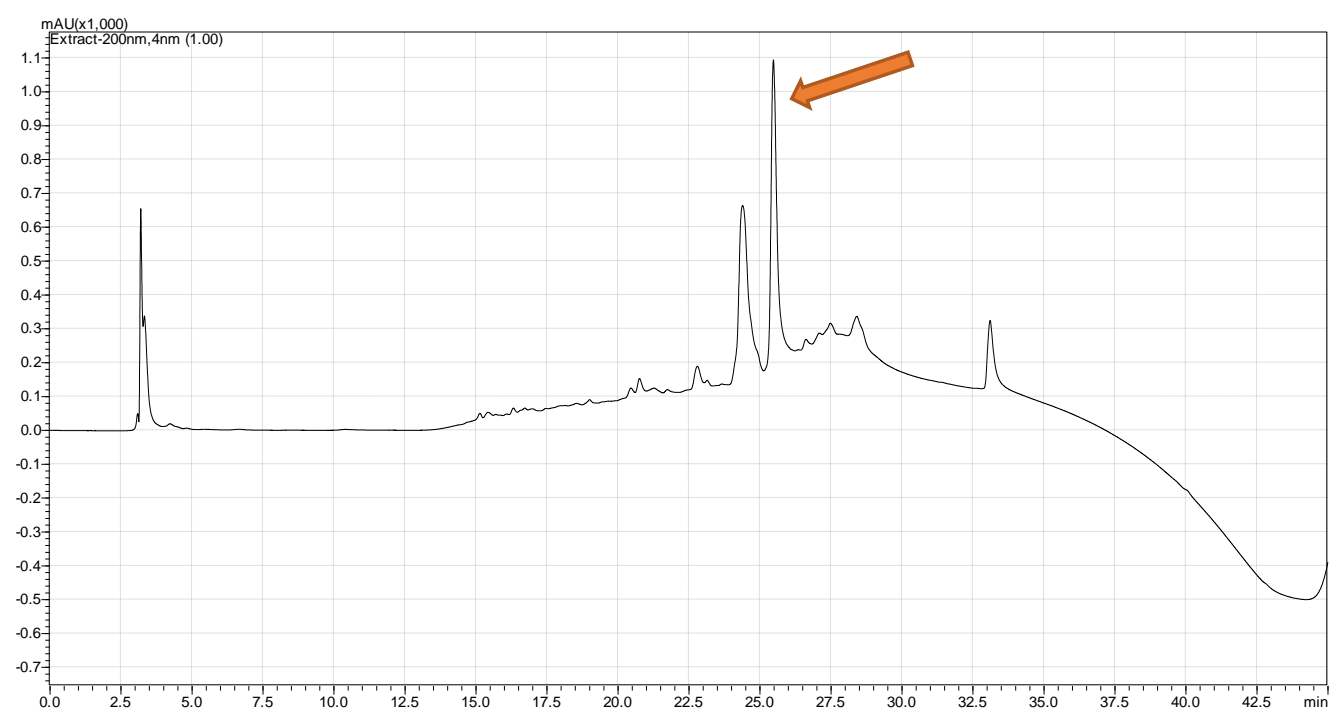

Legenda: A seta laranja indica o pico majoritário correspondente ao fragmento que teve sua porção Nterminal sequenciada. 
O pico majoritário foi coletado, concentrado e submetido ao sequenciamento $\mathrm{N}$-terminal por degradação de Edman. O sequenciamento deste fragmento revelou que a degradação deste híbrido está de fato ocorrendo entre as duas proteínas PspA94 e PdT. A posição exata da ruptura está indicada na sequência de aminoácidos da PspA94-PdT apresentada na Figura 35.

Figura 35 - Local principal de degradação na sequência de aminoácidos da PspA94-PdT sem espaçador.

\begin{abstract}
M R GSHHHHHGSACELEAPVASQSKAEKDYDAAVKKYKAAEED LKK AEA A R K Y DEDQKKTEEKAKETEEASKRQQAANLKYQLKL RE Y LKY I Q E K N K E K I AKAEKEM N A K Q E E D K E K A N L K K L A K VI PS D R L EKTRQEAEKAKKNIPELKKKVEEAKQKVDA AKQKVDA EHAKEV A P Q A KI A E L E Q V H R E Q D L K I N ES D SEDY V K G L R A PLQSELDTKKAKLLKLEELSGKIEELDAEIAELEVQLKDAE GN N NVEAYFKEGLEKTTAEKKAELEKAEADLKKAVDEPETPAPAPAP A P A E A P A P A A P A P P APAPKPEKT D D Q A E E Y AR R E E Y NRLPQQQLPKAESR | LEMANKAVNDFILAMNYDKKKLLTHQG ESIENRFIKE G N Q L D E F V VIERKKRSLSTNTSDISVTATNDSRL Y P G A L L V V DETLLEN N P L LA V D R A M T Y SID LPGLASSDSF L Q VEDPSNSSVRGA VNDLLAKWHQDYGQVNN VPAR M Y KKITAHS M E Q L K V K F G S D F E K T G N S L D I D F N S V HS G E K Q IQIVNFKQIYYT V S V D A V K N P G D VF Q D V T VEDLKQR GISAERPLVYISS V A Y G R V YLKLETTSKSDEVEAAFEALIKGVKVAPQTEWKQILDNTEVKAVI L G G D PS S A R V V T G K V D M V E D LIQEGSR F T A H P G L IS Y T T F LRD N V V ATFQNSTDYVETKVTAYRNGDLLLDHSGAYVAQYYITW DELSYNHQGKEVLTPKAW DRNGQDLTAHFTTSIPLKG N V R L S V KIRE G T G L A F E W W R T V Y EKT D L P L V R R TISIW G T L Y PQVE DK VE N D Stop
\end{abstract}

Legenda: A barra preta indica o local da clivagem. Em amarelo: aminoácidos provenientes do vetor de expressão pQE-30; em verde: PspA94; em vermelho: aminoácidos provenientes do sítio de restrição da enzima Xbal; em rosa: aminoácidos provenientes do sítio de restrição da enzima Xhol, em azul: PdT; sublinhados: aminoácidos identificados no sequenciamento. 


\subsection{Híbrido com espaçador flexível: PspA94-FL-PdT}

Visando solucionar o problema de estabilidade do híbrido, que está sofrendo quebra entre a PspA94 e a PdT, foi elaborada uma estratégia para construção de novos híbridos excluindo o sítio de clivagem identificado na proteína sem espaçador e incluindo espaçadores moleculares entre as duas proteínas. Além disso, a última região rica em prolina da PspA94 foi removida dessa nova construção, o que poderia contribuir para maior estabilidade, conforme discutido anteriormente (item 4.1).

\subsubsection{Obtenção do gene}

Para a clonagem com o espaçador flexível, foram utilizados os primers da Tabela 3, que constam no item 4.2. deste trabalho.

A sequência esperada da nova construção com o espaçador flexível e a sua composição em termos de porcentagem de aminoácidos é apresentada no Apêndice II. Esta construção possui pl teórico de 5,13 e massa molecular de $90750,4 \mathrm{~g} / \mathrm{mol}$ (Expasy, 2014).

O gene da PspA94 com a sequência inteira do espaçador foi amplificado em um termociclador, com as seguintes condições ótimas encontradas: 2 min a $94{ }^{\circ} \mathrm{C}, 30$ ciclos de $94 \stackrel{\circ}{\circ} \mathrm{C}$ por $30 \mathrm{~s}, 60 \stackrel{\circ}{\circ}$ por $60 \mathrm{~s}$ e $72 \stackrel{\circ}{\circ} \mathrm{C}$ por $90 \mathrm{~s}$ cada e $72 \stackrel{\circ}{\circ} \mathrm{C}$ a $5 \mathrm{~min}$. A concentração final de $\mathrm{MgCl}_{2}$ na reação foi de $4 \mathrm{mM}$. O gene da $\mathrm{PdT}$ foi amplificado também com a sequência inteira do espaçador nas mesmas condições. Ambos os produtos amplificados são apresentados no gel de agarose da Figura 36.

Figura 36 - Gel de agarose 1\% com o gene pspA94-FL amplificado nos poços A e B e com o gene $F L$-pdt amplificado nos poços C e D

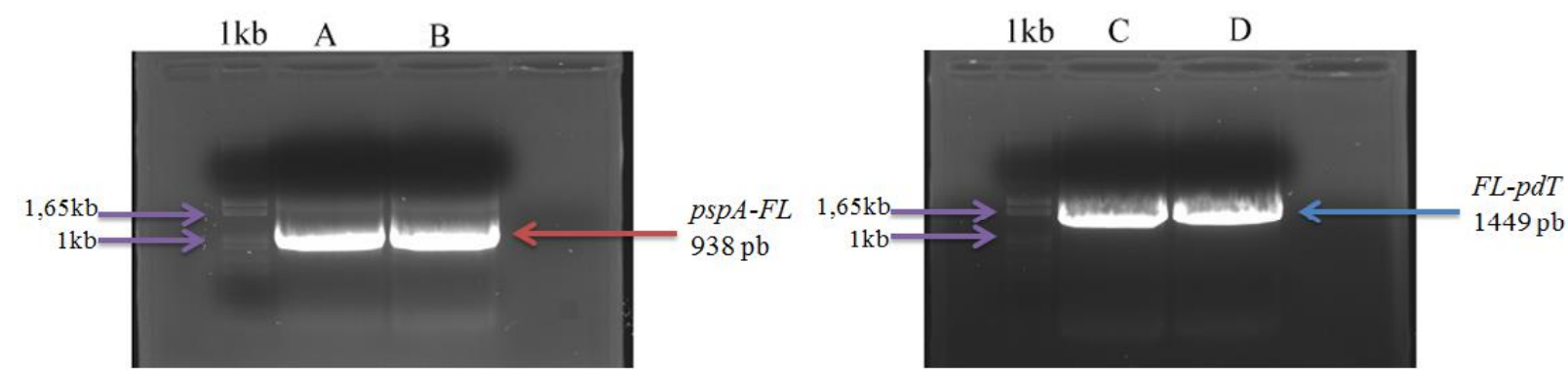


Para a segunda reação de PCR, foram utilizados como templates os produtos da primeira reação. Essa reação foi feita seguindo três metodologias diferentes:

- $1^{\underline{a}}$ metodologia:

Primeiramente a reação de overlapping foi realizada utilizando a enzima Taq com atividade proof-reading e foi feita uma varredura para definir a condição ótima: foram testadas concentrações de $\mathrm{MgCl}_{2}$ de 2 a $4 \mathrm{mM}$ e temperaturas de anelamento de 55 a $65{ }^{\circ} \mathrm{C}$. Nenhuma das condições foi capaz de produzir uma quantidade significativa do gene, então a melhor condição (concentração final de $\mathrm{MgCl}_{2}$ de $2 \mathrm{mM}$; 2 min a $94^{\circ} \mathrm{C}, 30$ ciclos de $94{ }^{\circ} \mathrm{C}$ por $30 \mathrm{~s}, 60 \stackrel{\circ}{\circ} \mathrm{C}$ por 60 s e $72 \stackrel{\circ}{\circ} \mathrm{C}$ por 2,5 min cada e $72 \stackrel{\circ}{ } \mathrm{C}$ a $5 \mathrm{~min}$ ) foi purificada para servir de template para uma nova reação. Esta nova reação foi feita nas mesmas condições da anterior, com exceção da temperatura de anelamento, que variou ao longo dos ciclos: 5 ciclos a $70{ }^{\circ} \mathrm{C}, 10$ ciclos a $65{ }^{\circ} \mathrm{C}, 10$ ciclos a $60^{\circ} \mathrm{C}$ e 5 ciclos a $55^{\circ} \mathrm{C}$. Desta forma foi possível amplificar satisfatoriamente o gene pspA94-FL-pdT cujo tamanho esperado do produto é de 2357 pares de bases.

Depois do produto de PCR ser purificado, adenilado, ligado ao vetor de clonagem pGEM-T e transformado em E. coli DH5a, não se observou o aparecimento de nenhuma colônia branca (com o inserto) na placa de LB com ampicilina na concentração de $100 \mu \mathrm{g} / \mathrm{mL}$, IPTG na concentração de $100 \mathrm{mM}$ e X-Gal na concentração de $80 \mu \mathrm{g} / \mathrm{mL}$. A hipótese levantada foi de que a baixa eficiência da reação de adenilação, que limita consideravelmente a quantidade de DNA na reação de ligação com o pGEM-T, tivesse impossibilitado a obtenção de colônias positivas para o inserto.

- $2^{\mathrm{a}}$ metodologia:

Uma vez que a $1^{\text {a }}$ metodologia não permitiu a seleção de transformantes com o inserto, foi feita uma nova reação de PCR utilizando os genes da Figura 36 como template e utilizando a enzima Taq DNA polimerase, que apesar de não ser de alta fidelidade possui a propriedade de adenilação das extremidades 3' e, assim, possibilita a reação de ligação com pGEM-T utilizando a quantidade de DNA 
recomendada pelo fabricante. Além disso, uma vez que o molde foi gerado com a polimerase de alta fidelidade, as chances de mutação seriam reduzidas em comparação com a utilização desta polimerase na reação de overlap extension. Desta forma, a transformação revelou uma quantidade satisfatória de colônias positivas para o inserto. As colônias tiveram seu DNA purificado e com ele foram feitos o mapa de restrição e o sequenciamento. O sequenciamento revelou mutações em todas as colônias. Por isso, a utilização da enzima Taq DNA polimerase sem atividade proofreading foi descartada.

- $3^{\mathrm{a}}$ metodologia:

Para contornar os obstáculos anteriormente descritos, foi feita uma nova reação de PCR utilizando novamente a enzima de alta fidelidade Q5 e sem utilizar gradiente de temperatura de anelamento, pois o gradiente de temperatura, apesar de aumentar o rendimento da reação, pode ter aumentado também a taxa de inserção de mutações na sequência do gene. Além disso, utilizou-se uma quantidade 5 vezes maior de DNA adenilado para a reação de ligação com o pGEM-T. Desta forma, foi possível obter uma maior quantidade de colônias brancas. Na Figura 37 é possível verificar o gene da proteína híbrida com linker flexível amplificado.

Figura 37 - Gel de agarose $0,8 \%$ com o produto de PCR para amplificação do gene da pspA94-FL-pdT

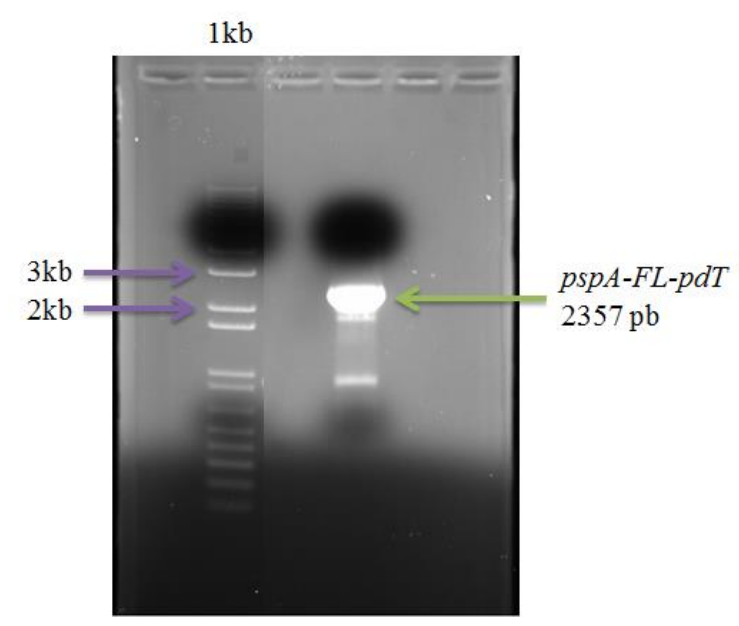


O produto do overlap extension PCR foi purificado do gel de agarose e inserido no pGEM-T, o plasmídeo com o inserto foi purificado e então foi realizado um mapa de restrição com as enzimas Hind III e EcoR I. A Tabela 12 apresenta o tamanho dos fragmentos esperados da digestão do plasmídeo + inserto com as enzimas utilizadas no mapa.

\begin{tabular}{c|c|c} 
Enzima & $\begin{array}{c}\text { Número de sítios de restrição } \\
\text { no plasmídeo + inserto }\end{array}$ & $\begin{array}{c}\text { Tamanho dos fragmentos } \\
\text { oriundos da digestão }(\mathbf{k b})\end{array}$ \\
\hline Hind III & 2 & 3,818 e 1,560 \\
\hline EcoRI & 3 & 2,$997 ; 1,470$ e 0,911
\end{tabular}

Tabela 12 - Fragmentos esperados nas digestões do plasmídeo pGEM-T/pspA94-FL-pdT de acordo com o mapa de restrição

Os fragmentos oriundos da digestão confirmaram a sequência dos clones $1 \mathrm{a}$ 7 (Figura 38). A digestão foi feita a $37^{\circ} \mathrm{C}$ por $1 \mathrm{~h}$. O sequenciamento confirmou apenas a sequência do clone 5 , e os demais foram descartados.

Figura 38 - Gel de agarose 1\% mostrando a digestão do plasmídeo pGEM-T/pspA94-FL-pdT purificado dos clones 1 a 7 .

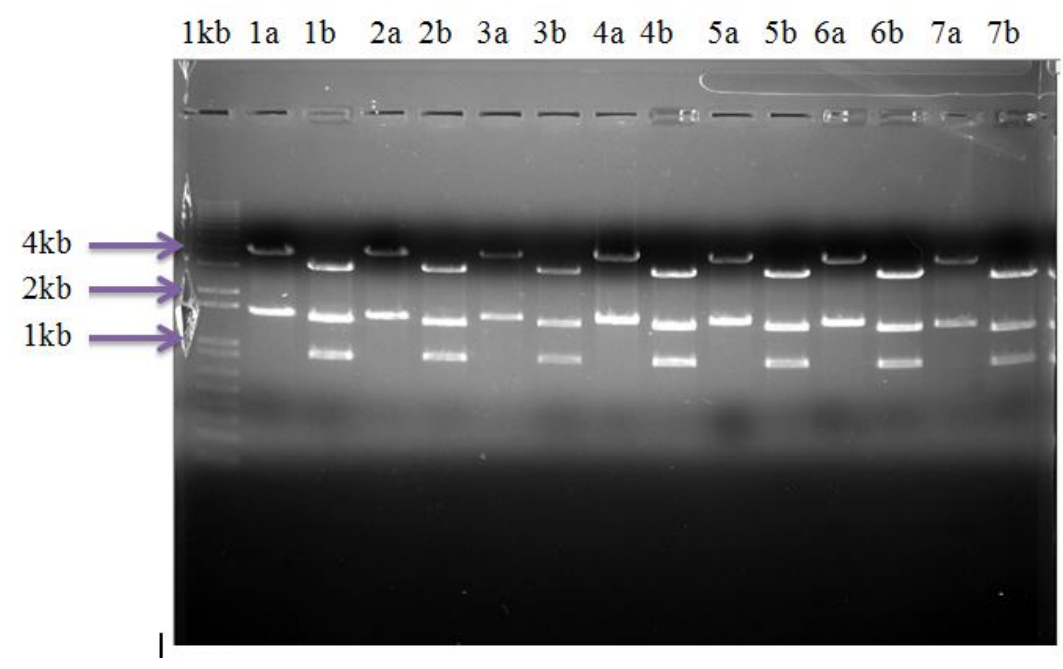

Legenda: Os números de 1 a 7 indicam os clones, a letra a indica os produtos da digestão com Hind III e a letra $\mathrm{b}$ indica os produtos da digestão com EcoR I. 


\subsubsection{Testes de expressão em E. coli BL21 Star (DE3)pLysS}

O plasmídeo do clone 5 foi digerido com as enzimas Nco I e Xho I e ligados em vetor $\mathrm{pET}$-28a tratado com fosfatase alcalina de intestino de bezerro (CIP), conforme manual do fornecedor do plasmídeo. Nesta construção, a proteína apresentará cauda de histidina C-terminal.

O gene de interesse foi inserido no vetor de expressão pET-28a e foi utilizado para transformação da cepa de E. coli BL21 Star (DE3) pLysS. Foi feito um screening de colônias por PCR para confirmar a presença do inserto (Figura 39); as colônias I, IV, V, VII, X, XI e XII foram descartadas.

Figura 39 - Produtos de PCR para seleção dos clones de E. coli BL21 Star (DE3) pLysS carregando pET-28a/pspA94-FL-pdt em gel de agarose 0,8\%

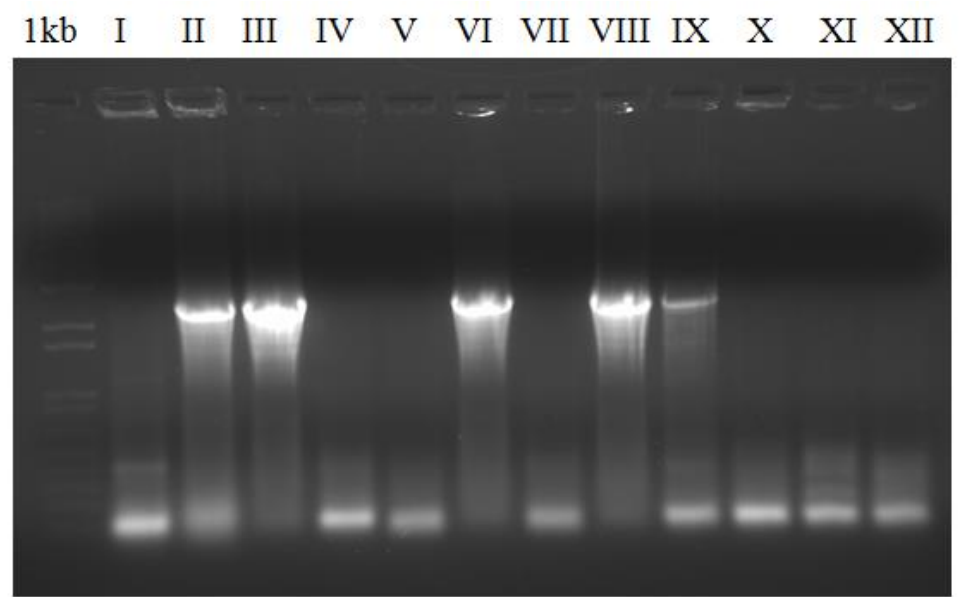

Para os testes de expressão foram escolhidos os clones II e III, denominados F5-II e F5-III respectivamente. A Figura 40 apresenta os géis SDS-PAGE dos testes de expressão com ambos os clones. A estabilidade dos plasmídeos, analisadas antes e $4 \mathrm{~h}$ após a indução, permaneceu em 100\%, indicando que as construções foram estáveis.

Através de Western Blot desses géis, apresentado na Figura 41, foi visto que 2 proteínas de tamanhos diferentes foram reconhecidas por anticorpos produzidos 
contra a célula inteira de pneumococo: uma delas com tamanho correspondente à proteína híbrida em menor quantidade e outra com tamanho menor em maior quantidade. Esse resultado fez com que duas hipóteses fossem levantadas.

A primeira hipótese foi a de que estaria acontecendo ligação inespecífica de alguma proteína da E. coli com o anticorpo utilizado, porém na expressão de outro híbrido de PspA e PdT (com linker rígido) nesta mesma linhagem de $E$. coli não houve reconhecimento de nenhuma outra banda no Western Blotting realizado com o mesmo anticorpo (resultados no item 5.3).

Figura 40 - SDS-PAGE das amostras dos cultivos de E. coli BL21 Star (DE3)pLysS para produção da proteína híbrida PspA94-FL-PdT.

$\begin{array}{llllll}1 & 2 & 3 & 4 & 5 & 6\end{array}$

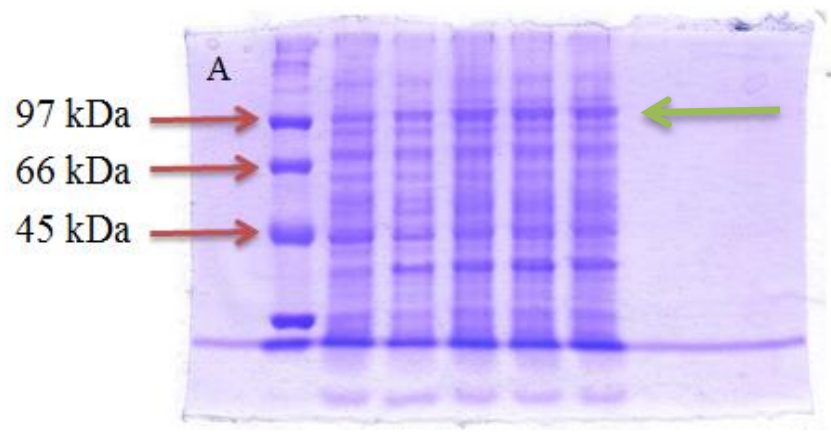

$\begin{array}{llllll}1 & 2 & 3 & 4 & 5 & 6\end{array}$

B

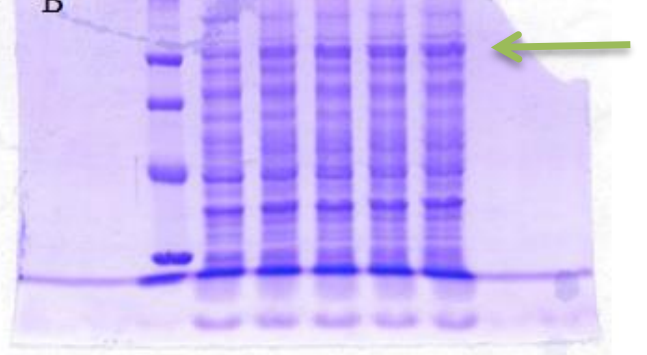

Legenda: A. Clone F5-II, B. Clone F5-III. 1. Padrão, 2. Antes da indução, 3. 1h de indução, 4. 2h de indução, 5 . 3h de indução, 6 . $4 \mathrm{~h}$ de indução. A seta verde indica a banda correspondente à proteína híbrida. 
Figura 41 - Western Blot amostras do cultivo de E. coli BL21 Star (DE3) pLysS para produção da proteína híbrida PspA94-FL-PdT.

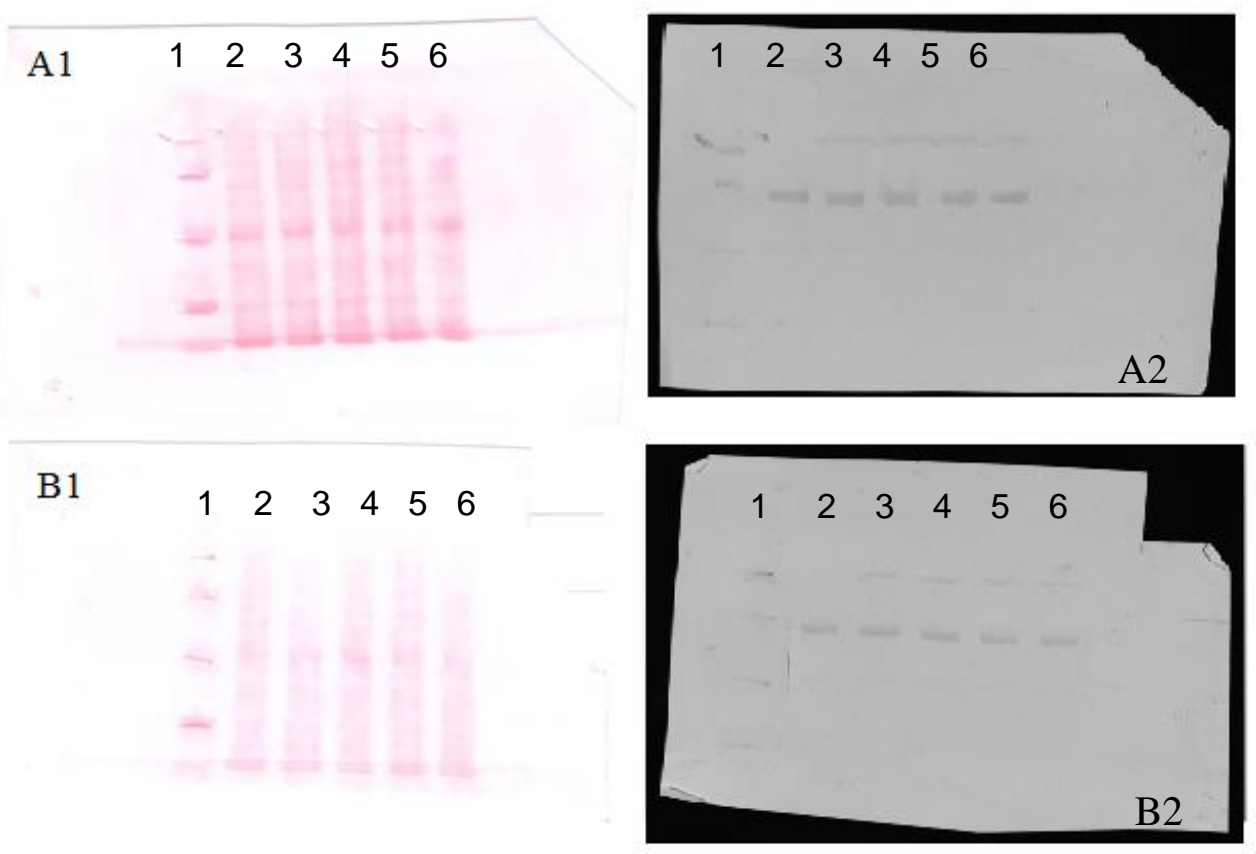

Legenda: A. Clone F5-II, B. Clone F5-III. À esquerda (A1 e B1): membranas de nitrocelulose coradas com Ponceau e à direita (A2 e B2): membranas reveladas com anticorpo contra célula inteira de pneumococo.1. Padrão, 2. Antes da indução, 3. $1 \mathrm{~h}$ de indução, 4. 2h de indução, 5. 3h de indução, 6. 4h de indução.

A segunda hipótese levantada foi de que a síntese da proteína estaria ocorrendo de forma truncada durante a tradução devido a algum códon raro para a $E$. coli presente na sequência do híbrido, ou de que ocorreria a formação de uma estrutura secundária do mRNA durante a tradução, o que faria com que ela fosse interrompida.

Apesar de a sequência do espaçador flexível ter sido desenhada otimizando sua sequência com códons preferenciais para $E$. coli, esse espaçador contém 8 glicinas uma em seguida da outra, o que poderia levar à limitação de tRNA para esse aminoácido. Além disso, há no total 11 códons raros para glicina - GGA (Dong et al., 1996; Makrides, 1996; Tegel et al., 2010) - presentes no gene da PspA94-PdT. Por isso, poderia estar acontecendo escassez de RNA transportadores de glicinas, pois eles têm que ser utilizados um logo em seguida do outro na região do espaçador e a presença de códons raros no restante da sequência agravaria o problema, acarretando assim o truncamento da tradução do híbrido na região próxima ao 
espaçador flexível. Esse truncamento faria então com que fosse obtida a proteína de menor tamanho observada no Western Blot. O mesmo problema havia sido verificado anteriormente por Goulart na tentativa de clonar o híbrido PspA94-PdT em pQE com esse mesmo espaçador (Dra. Cibelly Goulart, comunicação pessoal).

\subsubsection{Testes de expressão em E. coli Rosetta (DE3)}

Para checar e contornar a hipótese levantada de escassez de tRNA, o plasmídeo pET-28a/pspA94-FL-pdT foi utilizado para transformar a E. coli Rosetta (DE3), que produz tRNA para códons adicionais de glicina.

A Figura 42 apresenta 0 gel SDS-PAGE das amostras provenientes da $4^{4^{a}} \mathrm{~h}$ após a indução dos testes de expressão, realizados com 5 clones diferentes, para checar a presença do plasmídeo com o gene e a produção do híbrido. A indução foi realizada quando o cultivo alcançou $0,6<$ densidade óptica $<1,0$. $O$ clone de número 2 foi selecionado para seguir com a produção do híbrido.

A Figura 43 apresenta o SDS-PAGE do teste de expressão deste clone, nas 4 h após a indução da expressão. As amostras 2 e 7, que correspondem respectivamente à bactéria não-transformada e à bactéria transformada antes da indução, indicam que não está havendo escape, ou seja, a proteína só está sendo produzida após a indução.

Figura 42 - Teste de expressão gênica para produção de PspA94-FL-PdT em E. coli Rosetta (DE3)

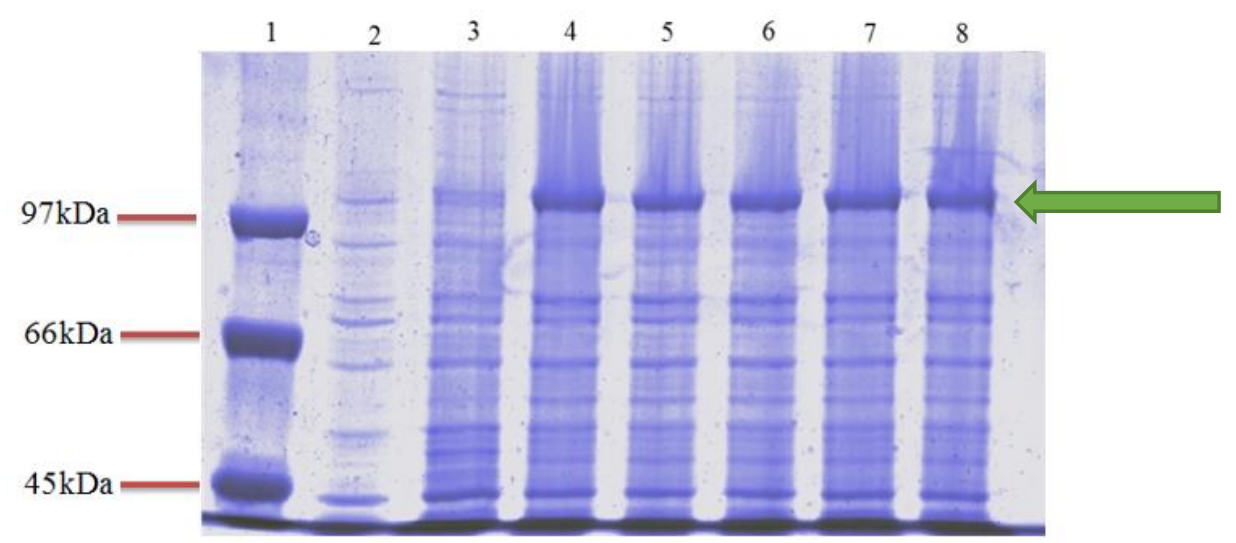


Legenda: 1. padrão molecular; 2. Clone 5 antes da indução; 3. E.coli Rosetta (DE3) sem o plasmídeo, 4 a 8. Clones de 1 a 5 após $4 \mathrm{~h}$ de indução. A flecha indica a molécula PspA94-FL-PdT.

Figura 43 - SDS-PAGE das amostras do cultivo do clone 2 de E. coli Rosetta (DE3) para produção da proteína híbrida PspA94-FL-PdT94.

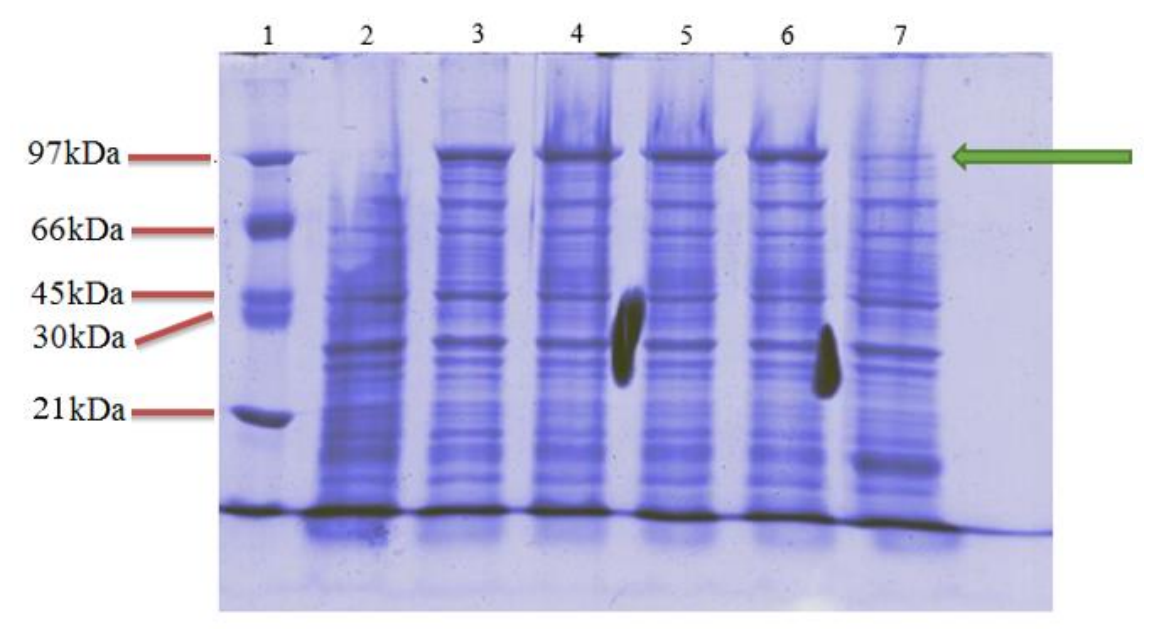

Legenda: 1. Padrão de massa molecular, 2. Antes da indução, 3. $1 \mathrm{~h}$ após indução, $4.2 \mathrm{~h}$ após indução, 5. $3 \mathrm{~h}$ após indução, 6. $4 \mathrm{~h}$ após indução, 7. E. coli Rosetta (DE3) sem o plasmídeo. A flecha indica o tamanho esperado para PspA94-FL-PdT.

Para analisar a integridade da proteína e seu reconhecimento por anticorpos contra célula inteira de pneumococo, foi realizado o Western Blotting apresentado na Figura 44.

Figura 44 - Western blotting das amostras do cultivo do clone 2 de E. coli Rosetta (DE3) para produção da proteína híbrida PspA94-FL-PdT.

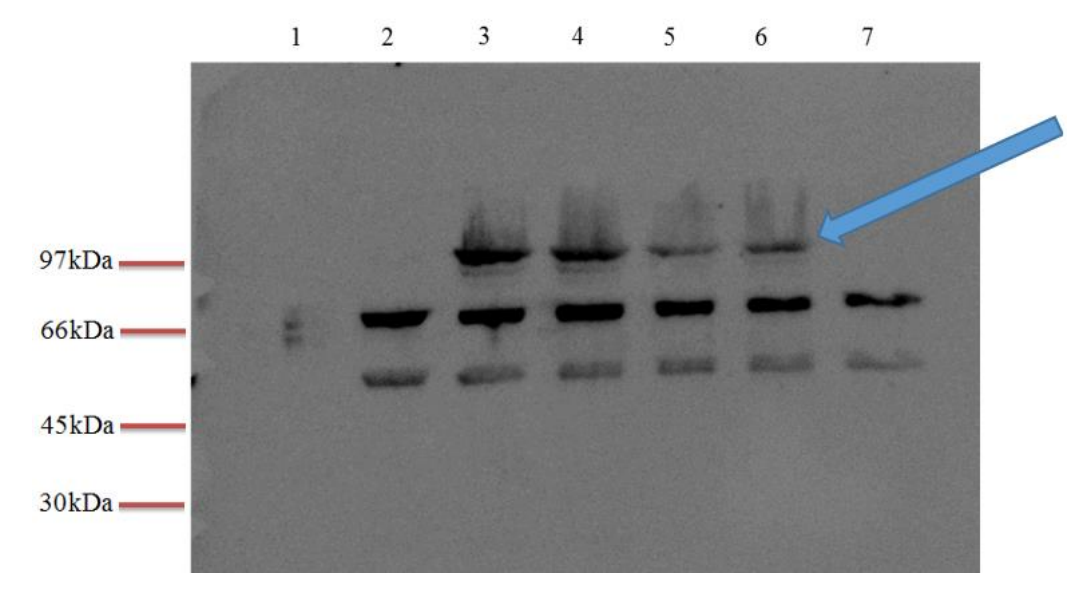

Legenda: 1. padrão molecular; 2. antes da indução; 3-6. 1-4 h após a indução; 7. E.coli Rosetta (DE3) não transformada. A flecha indica a PspA94-FL-PdT 
Apesar de aparecer mais de uma banda nas amostras do Western Blotting da Figura 44, somente a banda indicada pela flecha corresponde a PspA94-FL-PdT íntegra. Como as demais bandas abaixo desta também aparecem nas amostras de pré-indução e de E. coli vazia, é provável que elas sejam resultado de ligação inespecífica dos anticorpos com alguma proteína desta linhagem de $E$. coli que tenha alguma similaridade com o pneumococo. É sabido que diversos fatores podem ocasionar ligações inespecíficas de anticorpos como temperatura, $\mathrm{pH}$ e presença de íons (Bobrovnik et al., 2015).

Esta proteína foi purificada segundo o protocolo apresentado no item 4.8. Após a cromatografia de afinidade por íons $\mathrm{Ni}^{2+}$, as amostras foram congeladas para posterior análise a $-20^{\circ} \mathrm{C}$. Ao descongelar as amostras houve precipitação do híbrido. A fim de tentar ressolubilizá-lo, a sua concentração foi decrescida através da adição de mais tampão e também foi adicionada uréia até uma concentração final de $4 \mathrm{M}$, porém o híbrido permaneceu insolúvel. Este fenômeno não aconteceu com o híbrido PspA94-RL-PdT, cujos resultados são apresentados no item 5.3. a seguir.

O linker flexível além de separar os domínios das duas proteínas que formam o híbrido, permite um certo movimento e interação entre os domínios, a contrário do linker rígido. Essa interação entre os domínios pode ter contribuído para um enovelamento diferente do híbrido e consequente formação de agregados e precipitação no descongelamento. O processo de congelamento e descongelamento pode causar estresse à proteína e favorecer o fenômeno de desidratação seguido de agregação. Para contornar este problema, o híbrido poderia ser armazenado em solução com estabilizantes de baixa massa molecular antes do seu congelamento (Liao et al., 2002).

\subsection{Híbrido com espaçador rígido: PspA94-RL-PdT}

Assim como no híbrido com espaçador flexível, na construção do híbrido com espaçador rígido a última região rica em prolina da PspA94 foi removida. O linker rígido utilizado possui a sequência: 5' AEAAAKEAAAKA 3'. 


\subsubsection{Obtenção do gene}

Para a clonagem com o espaçador rígido, foram utilizados os primers da Tabela 3, que constam no item 4.2 deste trabalho.

O Apêndice III apresenta a sequência esperada da nova construção com o espaçador rígido e a sua composição em termos de porcentagem de aminoácidos. $O$ híbrido em questão possui pl teórico de 5,15 e massa molecular de 91673,64 g/mol (Expasy, 2014).

O gene da PspA94 foi amplificado com um trecho do espaçador em um termociclador, com as seguintes condições ótimas encontradas: 2 min a $94{ }^{\circ} \mathrm{C}, 30$ ciclos de $94 \stackrel{\circ}{\circ}$ por $30 \mathrm{~s}, 60{ }^{\circ} \mathrm{C}$ por $30 \mathrm{~s}$ e $72{ }^{\circ} \mathrm{C}$ por $90 \mathrm{~s}$ cada e $72{ }^{\circ} \mathrm{C}$ a $5 \mathrm{~min}$. A concentração final de $\mathrm{MgCl}_{2}$ na reação foi de $3 \mathrm{mM}$. O gene da PdT foi amplificado com o outro trecho do espaçador nas seguintes condições: 2 min a $94{ }^{\circ} \mathrm{C}, 30$ ciclos de $94^{\circ} \mathrm{C}$ por $30 \mathrm{~s}, 58^{\circ} \mathrm{C}$ por 30 s e $72^{\circ} \mathrm{C}$ por 90 s cada e $72{ }^{\circ} \mathrm{C}$ a $5 \mathrm{~min}$. A concentração final de $\mathrm{MgCl}_{2}$ foi de $4 \mathrm{mM}$. Ambos os produtos amplificados são apresentados no gel de agarose da Figura 45.

Figura 45 - Gel de agarose $1 \%$ com o gene $R L-p d t$ amplificado no poço A e com o gene pspA94- $R L$ amplificado nos poços B, C e D

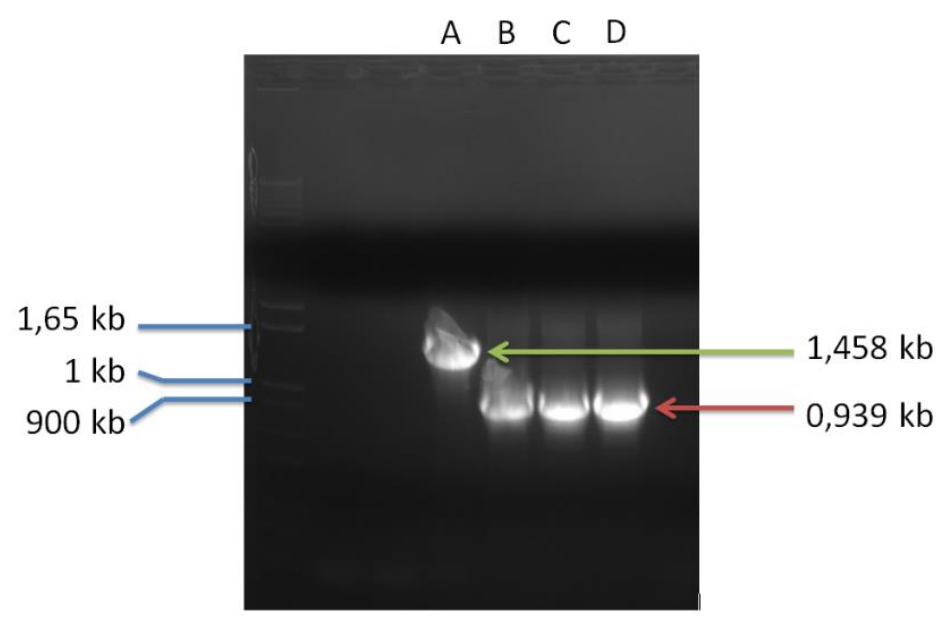

Para a segunda reação de PCR, foram utilizados como templates os produtos da primeira reação. Na Figura 46 é possível verificar o gene da proteína híbrida com linker rígido amplificado por PCR; o tamanho esperado do produto é de 2363 pares 
de bases. Nesta reação a concentração final de $\mathrm{MgCl}_{2}$ foi de $4 \mathrm{mM}$. A reação foi realizada nas seguintes condições: 2 min a $94{ }^{\circ} \mathrm{C}, 30$ ciclos de $94{ }^{\circ} \mathrm{C}$ por $30 \mathrm{~s}, 60{ }^{\circ} \mathrm{C}$ por 60 s e $72 \stackrel{\circ}{\circ}$ por 150 s cada e $72 \stackrel{\circ}{\circ}$ a 5 min.

O produto do overlap extension $P C R$ foi adenilado e inserido no pGEM-T, o plasmídeo com o inserto foi purificado e então foi realizado um mapa de restrição com as enzimas Hind III e EcoR I. A Tabela 13 apresenta o tamanho dos fragmentos esperados da digestão do plasmídeo + inserto com as enzimas utilizadas no mapa.

Figura 46 - Gel de agarose com o produto de PCR de amplificação do gene da proteína híbrida com espaçador rígido: $p s p A 94-R L-p d T$
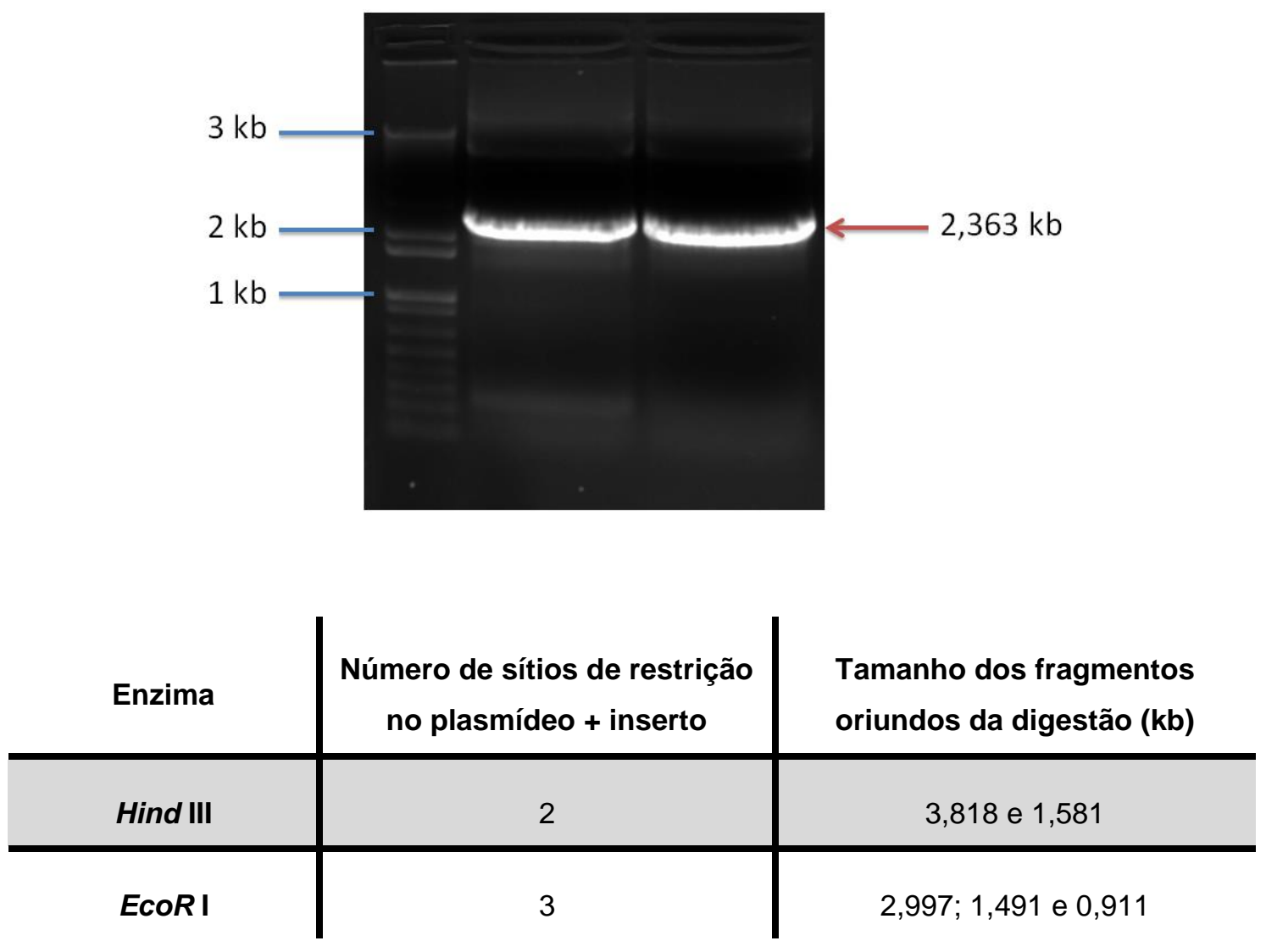

Tabela 13 - Fragmentos esperados nas digestões do plasmídeo pGEM-T/pspA94-RL-pdT de acordo com o mapa de restrição

Os fragmentos oriundos da digestão confirmaram a sequência dos clones $1 \mathrm{a}$ 4 e o clone 5 foi descartado (Figura 47). A digestão foi feita a $3{ }^{\circ} \stackrel{\circ}{C}$ por $1 \mathrm{~h}$. 
Os plasmídeos foram então digeridos com as enzimas Nco I e Xho I e ligados em vetor pET-28a tratado com fosfatase alcalina de intestino de bezerro (CIAP), conforme manual do fornecedor do plasmídeo. A proteína será produzida com cauda de histidina C-terminal.

O sequenciamento dos clones apresentou mutações nos clones 1,2 e 3. 0 clone 4 foi então utilizado.

Figura 47 - Gel de agarose 1\% mostrando a digestão do plasmídeo pGEM-T/pspA94-RL-pdT purificado dos clones 1 a 5 .

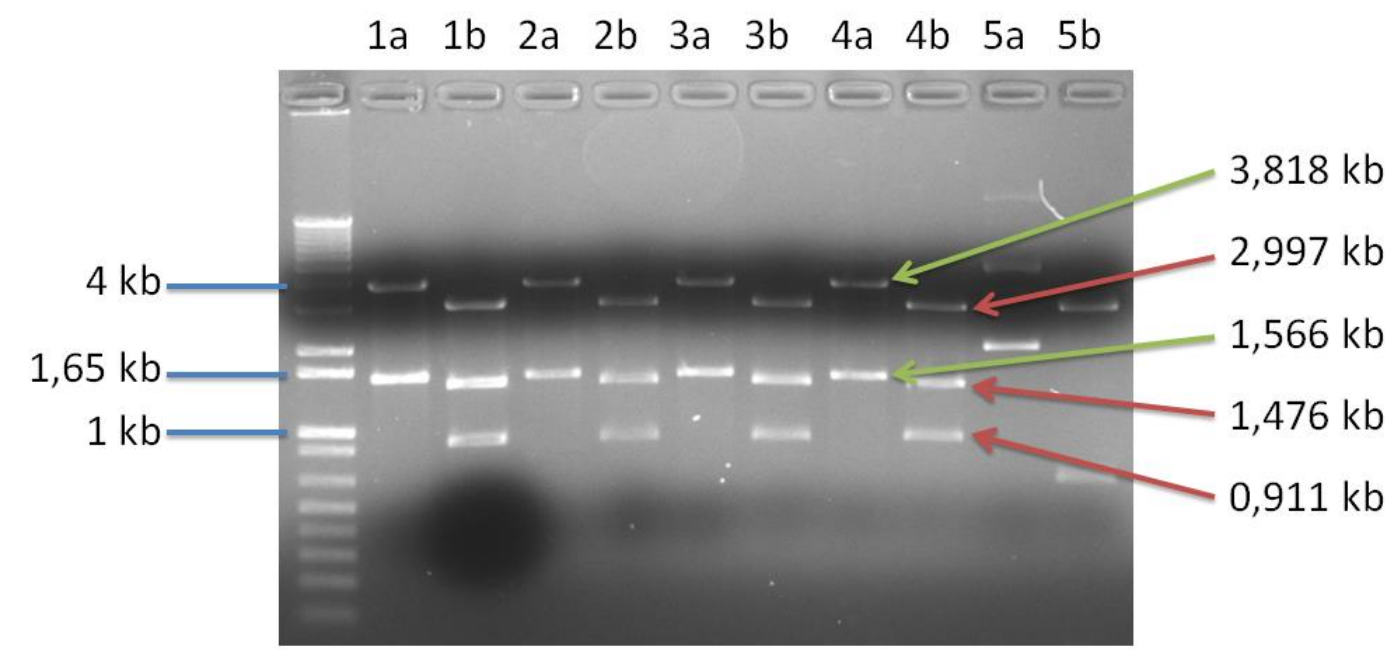

Legenda: Os números de 1 a 5 indicam os clones, a letra a indica digestão com Hind III e a letra b indica digestão com EcoR I. As indicações em verde correspondem aos fragmentos provenientes da digestão com Hind III e as indicações vermelhas da digestão com EcoR I.

\subsubsection{Testes de expressão}

O plasmídeo pET-28a carregando o gene de interesse foi utilizado para transformação da cepa de E. coli BL21 (DE3). Esta linhagem de expressão, a princípio, não foi capaz de expressar a proteína em quantidade visível em gel de SDSPAGE corado por azul de Coomassie, e por isso foi substituída pela linhagem BL21 Star (DE3) pLysS. Foi feito um screening de colônias por PCR para confirmar a presença do inserto (Figura 48); as colônias 1, 8 e 10 foram descartadas e a 7 foi utilizada. 
Figura 48 - Produtos de PCR para seleção dos clones de E. coli BL21 Star (DE3)pLysS em gel de agarose $0,8 \%$.

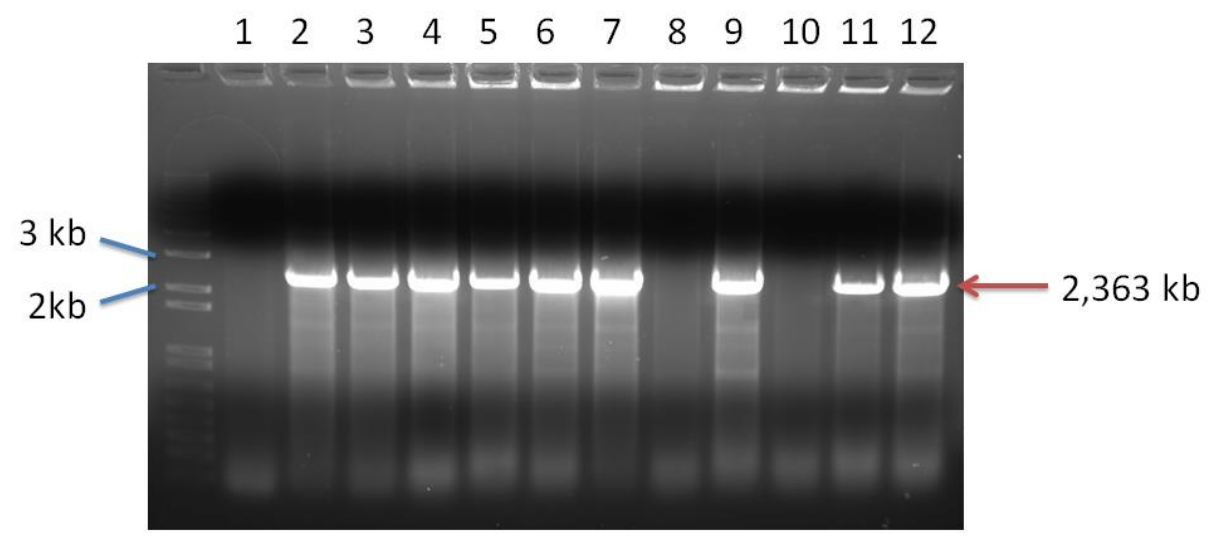

Legenda: A seta vermelha indica o tamanho esperado para o gene da proteína híbrida PspA94-RL-PdT com espaçador rígido

A linhagem BL21 Star (DE3) pLysS permitiu a produção da proteína híbrida em quantidades mais elevadas (Figura 49). A proteína foi reconhecida por anticorpos produzidos contra a célula inteira de pneumococo através de Western Blot (Figura 50). A estabilidade do plasmídeo, analisada antes e $4 \mathrm{~h}$ após a indução, permaneceu em $100 \%$, indicando que a construção foi estável.

Figura 49 - SDS-PAGE das amostras do cultivo de E. coli BL21 Star (DE3)pLysS, clone R4VII, para produção da proteína híbrida PspA94-RL-PdT.

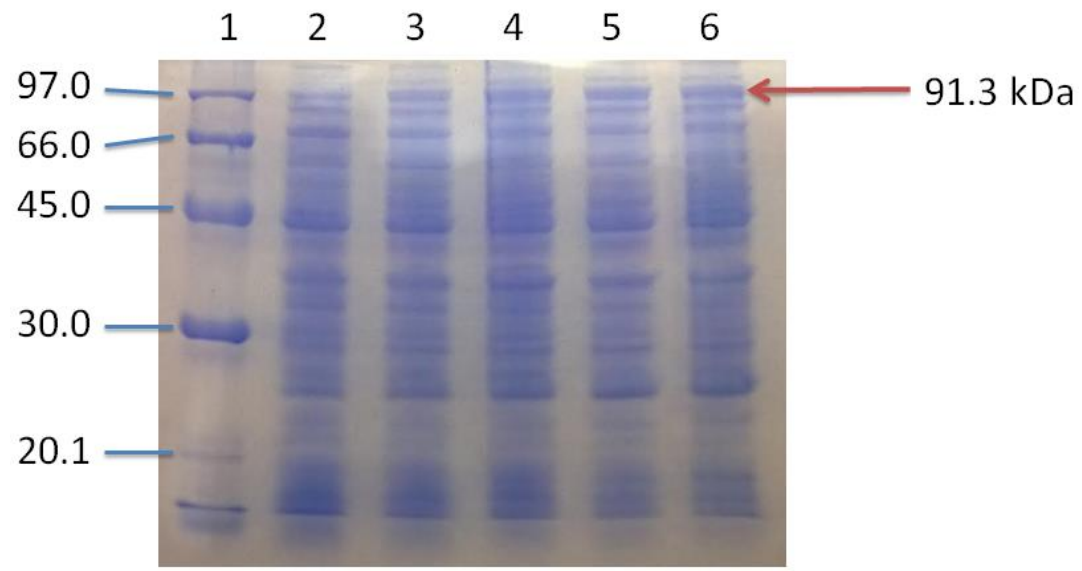

Legenda: 1. Padrão, 2. Antes da indução, 3. 1h de indução, 4. 2h de indução, 5. 3h de indução, 6. 4h de indução. A seta indica a banda correspondente à proteína híbrida. 
Durante o trabalho, foi levantada a sugestão de a E. coli BL21 (DE3) ser antiga e já conter algumas mutações em relação à linhagem comercial que prejudicassem a produção de proteínas recombinantes. Por isso, foi adquirida do fabricante um novo lote de E. coli BL21 (DE3) e os resultados mostraram que este híbrido também poderia sim ser produzido nesta linhagem (ver a seguir).

Figura 50 - Western Blot das amostras do cultivo de E. coli BL21 Star (DE3)pLysS para produção da proteína híbrida PspA94-RL-PdT.

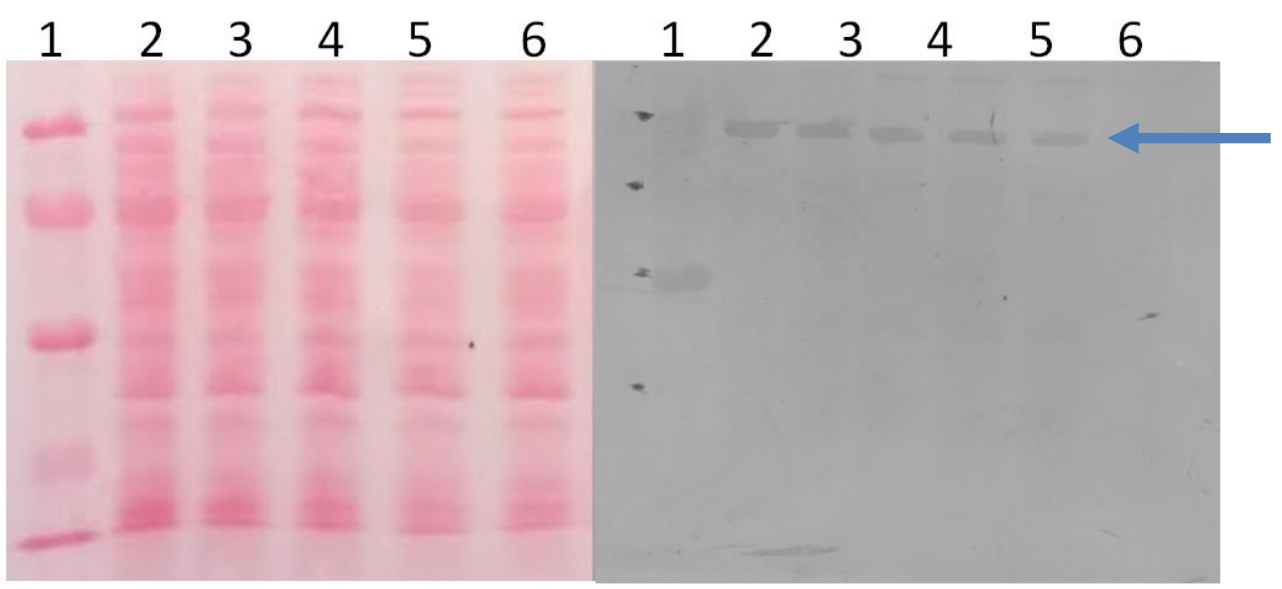

Legenda: À esquerda: membrana de nitrocelulose corada com Ponceau e à direita: membrana revelada com anticorpo contra célula inteira de pneumococo.1. Padrão, 2. Antes da indução, 3. $1 \mathrm{~h}$ de indução, 4. $2 \mathrm{~h}$ de indução, 5 . 3h de indução, 6 . 4h de indução.

\subsubsection{Parâmetros cinéticos}

Os experimentos a seguir foram realizados para estimar o valor de velocidade específica máxima de crescimento e estimar a correlação entre a DO e a massa seca da linhagem E. coli BL21 (DE3) transformada com pET28a/pspA94-RL-pdT antes de transferir o cultivo para o biorreator.

O gráfico da Figura 51 apresenta a curva de crescimento do cultivo de $1 \mathrm{~L}$ realizado em frasco tunair com meio complexo LB, cuja composição está apresentada no item 4.4 .

Através dos dados da curva de crescimento celular, foi possível obter a velocidade específica máxima de crescimento. A Figura 52 apresenta o gráfico do 
logaritmo neperiano da DO pelo tempo. A integração da equação 1 (item 4.6) leva ao valor de $\mu$ máx, que corresponde ao coeficiente angular da reta: $0,58 \mathrm{~h}^{-1}$. Este valor é comparável a outro valor encontrado anteriormente em nosso laboratório utilizando mesma linhagem de E. coli e mesmo substrato de $0,54 \mathrm{~h}^{-1}$ (Carvalho, 2009).

Figura 51 - Curva de crescimento de E. coli BL21 (DE3) com plasmídeo pET-28a/pspA94-RLpdt em $1 \mathrm{~L}$ de meio LB com canamicina em frasco Tunair agitado

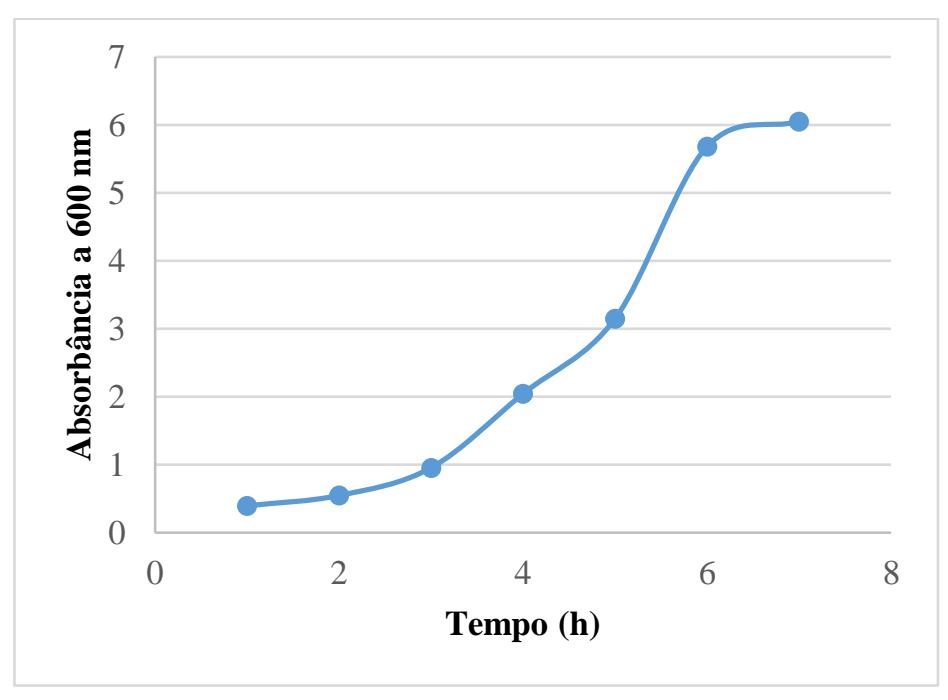

Os dados de DO e massa seca coletados foram plotados em um gráfico, apresentado na Figura 53. A partir do ajuste dos dados em uma reta, é possível obter através do coeficiente angular, a relação de DO por massa seca média em g/L, resultando na correlação em que 1,0 unidade de DO corresponde a $0,34 \mathrm{~g} / \mathrm{L}$ de massa celular seca. 
Figura 52 - Gráfico de $\ln (\mathrm{DO})$ pelo tempo para obtenção do valor de $\mu_{\text {máx }}$ do cultivo de $E$. coli BL21 (DE3) com plasmídeo pET-28a/pspA94-RL-pdt em 1 L de meio LB em frasco Tunair agitado

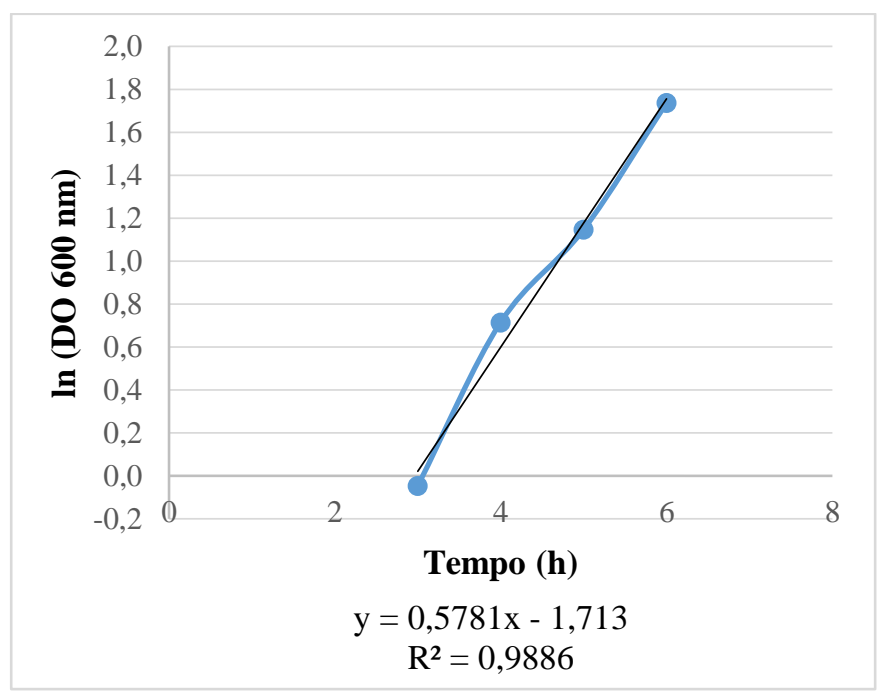

Figura 53 - Gráfico de massa seca (g/L) por DO do cultivo de E. coli BL21 (DE3) com plasmídeo pET-28a/pspA94-RL-pdt em $1 \mathrm{~L}$ de meio $\mathrm{LB}$ em frasco Tunair agitado

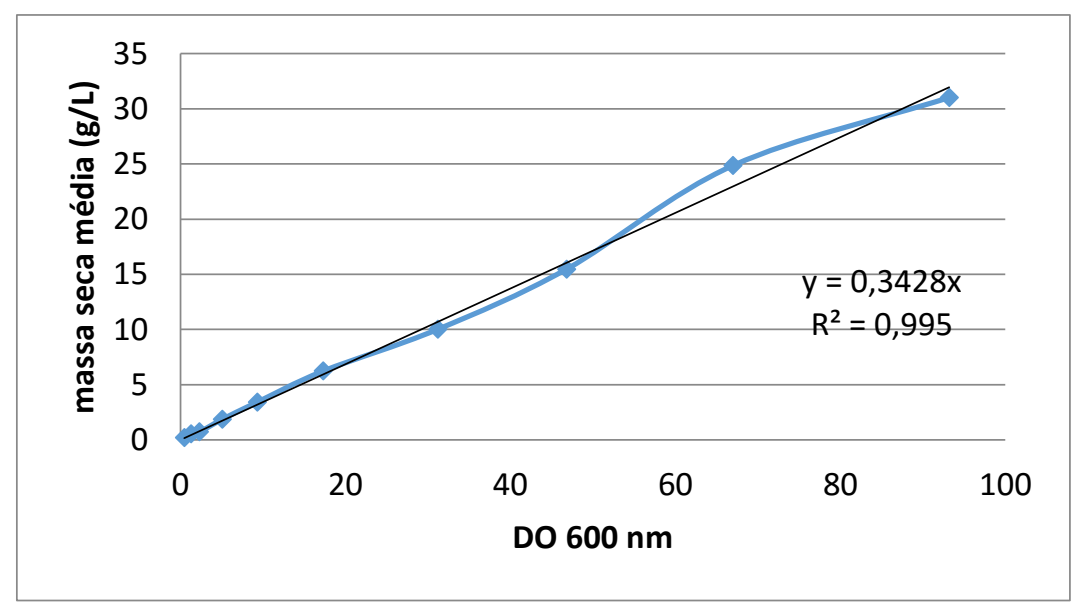

\subsubsection{Cultivo em biorreator}

Em posse dos parâmetros cinéticos estimados no item 5.3.3, foi planejado um cultivo em biorreator de $10 \mathrm{~L}$ utilizando o mesmo clone de E. coli BL21 (DE3)

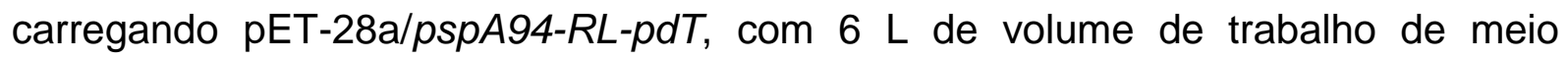
quimicamente definido CDM, cuja composição está apresentada no item 4.7. 
O inóculo foi preparado em $200 \mathrm{~mL}$ de meio quimicamente definido CDM a partir de uma única colônia obtida em placa de meio LB com antibiótico canamicina. O inóculo cresceu por aproximadamente $10 \mathrm{~h}$ e para início do cultivo no biorreator com DO de 0,1 , foram transferidos $112 \mathrm{~mL}$.

O oxigênio dissolvido foi mantido a $30 \%$ durante todo o cultivo através do controle em cascata da agitação (até 1000 rpm), alimentação da aeração com ar comprimido e enriquecimento com oxigênio comprimido.

O valor de velocidade específica máxima de crescimento foi também calculado através do gráfico da Figura 54 . O valor encontrado de $0,43 \mathrm{~h}^{-1}$ foi por volta de $25 \%$ menor do que o valor de $\mu$ máx encontrado no cultivo em frasco tunair de $1 \mathrm{~L}$ com meio LB. Essa diferença é decorrência das composições distintas dos meios de cultura, uma vez que a bactéria tem de sintetizar todos os componentes celulares a partir de glicose e amônia quando cultivada em CDM, enquanto no meio LB os aminoácidos e peptídeos já estão disponíveis (Jensen e Carlsen, 1990). Apesar do meio quimicamente definido geralmente não ser capaz de promover um crescimento semelhante ao meio complexo, ele traz muitas outras vantagens como: maior reprodutibilidade; facilita o estudo das rotas metabólicas do microorganismo e é considerado padrão de GMP - good manufacturing practices pelas agências regulatórias (Zhang e Greasham, 1998).

Figura 54 - Gráfico de $\ln (\mathrm{DO})$ pelo tempo para obtenção do valor de $\mu_{\operatorname{máx}}$ do cultivo de $E$. coli BL21 (DE3) com plasmídeo pET-28a/pspA94-RL-pdt em biorreator com meio CDM

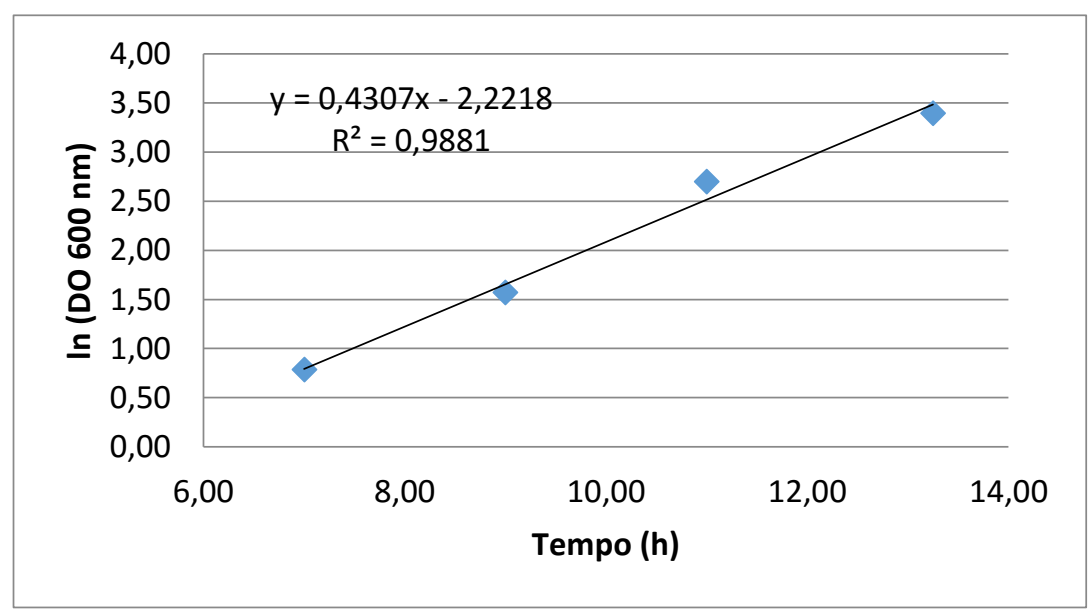


O valor de Yx/s calculado para a fase exponencial de crescimento, conforme indicado no item 4.7, foi de $0,37 \mathrm{~g}$ de células / $\mathrm{g}$ de glicose. Esse valor é comparável a outro já obtido em nosso laboratório com a mesma linhagem de E. coli e mesmo substrato:0,33 g de células / $\mathrm{g}$ de glicose (Carvalho, 2009).

O momento da indução está indicado no gráfico do cultivo apresentado na Figura 55. Por volta da décima $5^{\mathrm{a}} \mathrm{h}$ de cultivo houve um problema na alimentação de ar, que demorou por volta de $30 \mathrm{~min}$ para se reestabelecer. Isso fez com que o momento ideal da indução não fosse notado em tempo real. Após o reestabelecmento da alimentação de ar, foi notado o pico de oxigênio no meio e a indução foi realizada adicionando a solução de lactose $20 \mathrm{~g} / \mathrm{L}$ com IPTG 0,1 mM. No gráfico da Figura 55 também estão os valores de glicose residual determinados posteriormente ao cultivo. A estabilidade do plasmídeo foi monitorada antes e depois da indução, permanecendo $100 \%$ estável.

Figura 55 - Gráfico do cultivo em biorreator de E. coli BL21 (DE3) para produção de PspA94RL-PdT em $6 \mathrm{~L}$ de meio CDM no modo batelada. A seta verde indica o momento da indução.

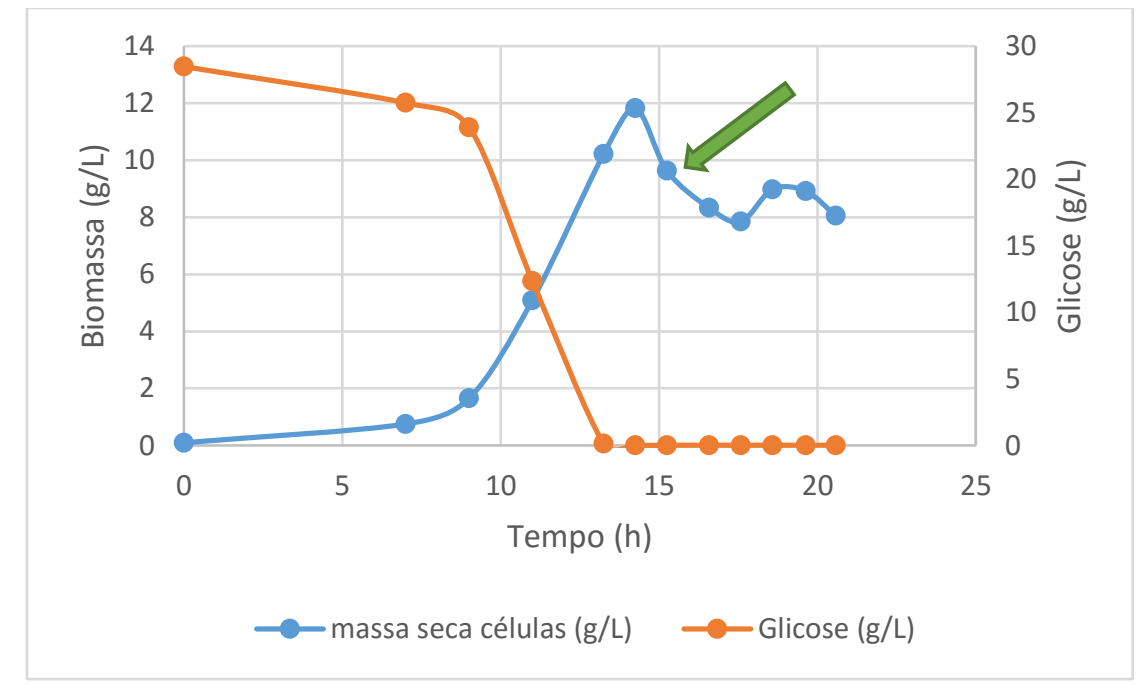

A Figura 56 apresenta o gel SDS-PAGE das amostras do cultivo. Apesar de não ter havido escape de expressão da proteína híbrida antes da indução, as bandas correspondentes ao híbrido que podem ser vistas nas amostras retiradas do cultivo 
após a indução representam menos que $10 \%$ de todas as proteínas da amostra. O baixo rendimento pode ser decorrente do grande tamanho da proteína que se está produzindo, aproximadamente $90 \mathrm{kDa}$. Além disso, muito embora este híbrido não contenha uma sequência de glicinas consecutivas no espaçador, ainda sim existem 9 códons raros na sua sequência nucleotídica que são correspondentes às glicinas (GGA). Portanto, é possível que a linhagem de E. coli Rosetta possa aumentar a oferta de tRNA para esse códon e, assim, aumentar a os níveis de expressão do híbrido. Aumentar a produtividade é muito importante quando se pensa que, a priori, a vantagem de se expressar um híbrido é produzir e purificar dois antígenos de uma única vez. Para que essa produção conjunta seja economicamente viável é conveniente que se otimize a produção do híbrido. Essa otimização pode ser estudada avaliando outras linhagens de E. coli que aumentem a taxa de tradução da proteína como, por exemplo, a Rosetta ou a BL21 Star (DE3)pLysS, que já mostrou bons resultados para produção deste híbrido em biorreator (ver adiante), e investigando outros modelos de produção em biorreator que costumam aumentar a produtividade, como por exemplo cultivo em batelada alimentada (Jensen e Carlsen, 1990; Yee e Blanch, 1992; Kotik et al., 2004), cultivo com reciclo de células (Lee et al., 1989), cultivo contínuo com biorreatores em série (Schmideder e Weuster-Botz, 2017), etc.

Figura 56 - SDS-PAGE da fração solúvel das amostras do cultivo em biorreator de $E$. coli BL21 (DE3) para produção de PspA94-RL-PdT

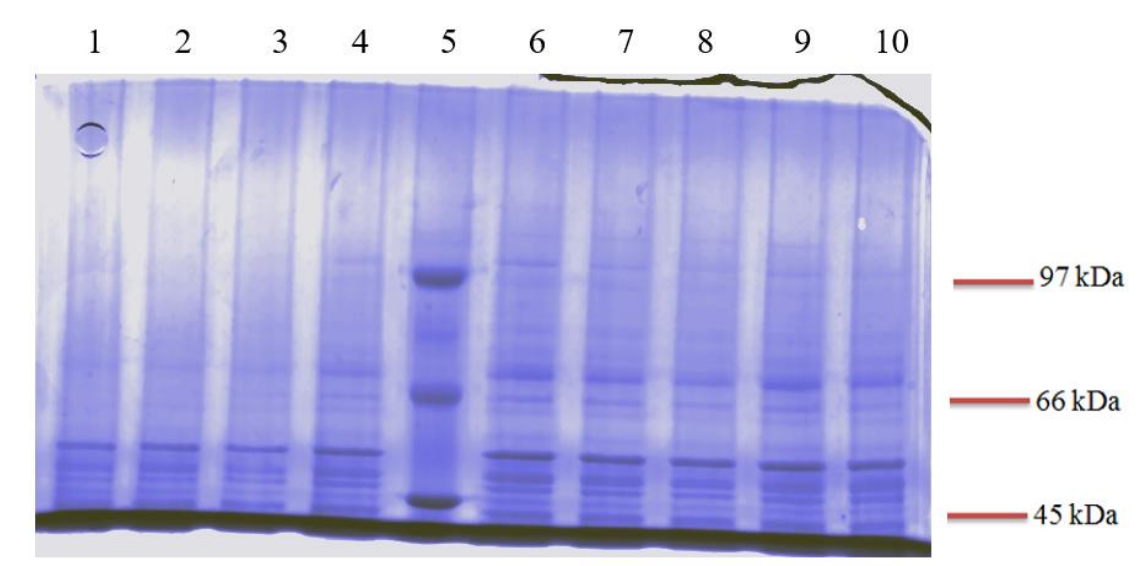

Legenda: 1 . Amostra $9 \mathrm{~h}$ cultivo, 2. Amostra $11 \mathrm{~h}$ de cultivo, 3 . Amostra $14,25 \mathrm{~h}$ de cultivo, 4 . Amostra de $15,25 \mathrm{~h}$ de cultivo e momento da indução, 5. Padrão de massa molecular, 6 . Amostra $16,5 \mathrm{~h}$ de cultivo, 7. Amostra 17,5 h de cultivo, 8. Amostra 18,5 h de cultivo, 9. Amostra 19,5 h de cultivo, 10. Amostra $20,5 \mathrm{~h}$ de cultivo. 


\subsubsection{Purificação de PspA94-RL-PdT}

O híbrido purificado nesta seção foi produzido em biorreator pela equipe do LadaBio da UFSCar, utilizando a linhagem de E. coli BL21 Star (DE3) pLysS. Nesta purificação, utilizou-se o tempo de 10 min para o processo de lise e a concentração final de $0,1 \%$ CTAB foi empregada para precipitação de impurezas na etapa de clarificação. Foram utilizadas as cromatografias de troca iônica, afinidade por metal e de gel filtração.

A Figura 57 apresenta o gel SDS-PAGE com amostras das etapas deste processo, bem como a pureza de PspA94-RL-PdT em cada etapa. Ao final da terceira etapa cromatográfica a pureza alcançada foi de 95\%. A Tabela 14 mostra a recuperação e pureza obtida em cada etapa.

Figura 57 - SDS-PAGE da purificação da PspA94-RL-PdT produzida em biorreator em E. coli BL21 Star (DE3) pLysS

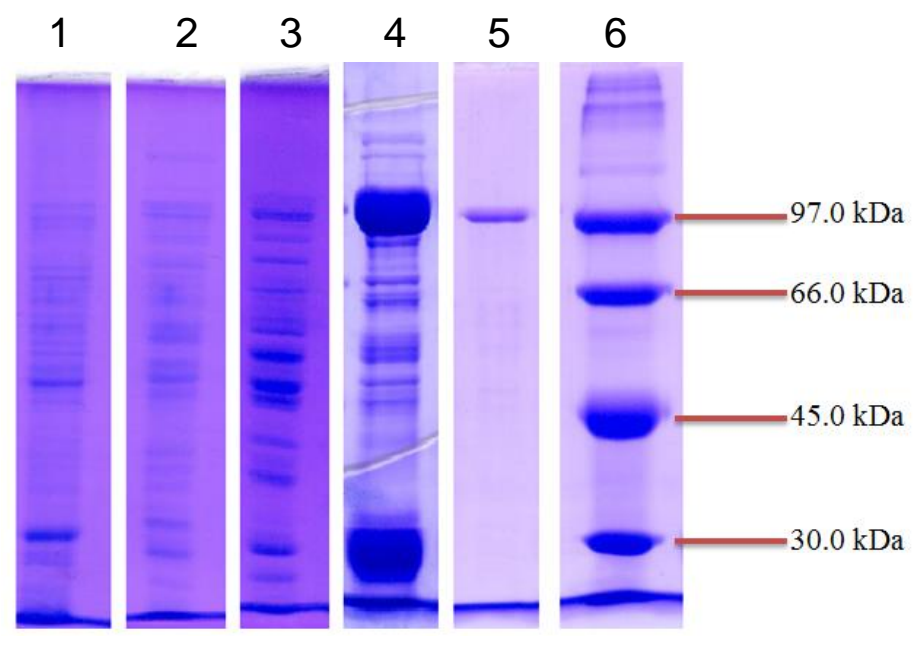

Legenda: 1. Homogenato (4,0\% de pureza), 2. clarificado com $0,1 \%$ CTAB (5,0\% de pureza), 3. Eluição $200 \mathrm{mM} \mathrm{NaCl}$ Q-Sepharose $(8,0 \%$ de pureza), 4. Eluição fração 3A2 IMAC-Sepharose $(43,0 \%$ de pureza), 5 Eluição Superose 12 (95,1\% de pureza), 6 . Padrão de massa molecular 
O gel SDS-PAGE das amostras da segunda etapa cromatográfica (Figura 58 A, canaletas 3-5 e 7-9), em IMAC-Sepharose carregada com $\mathrm{Ni}^{2+}$, revelou duas bandas predominantes nas eluições, uma de cerca de $97 \mathrm{kDa}$, correspondente à PspA94-RL-PdT, e outra de aproximadamente $30 \mathrm{kDa}$. Como a cromatografia de afinidade por metal costuma ter alta especificidade pela proteína contendo cauda de histidinas, foi feito um Western Blot para verificar se a banda predominante de menor tamanho não corresponderia à proteína híbrida degradada. O resultado do Western Blot (Figura $58 \mathrm{C}$ ) revelou que a banda correspondia a uma impureza proveniente da linhagem de E. coli utilizada (BL21 Star (DE3) pLysS), já que os anticorpos anti célula inteira de pneumococo não foram capazes de reconhecer a proteína desta banda. Segundo Bolanos-Garcia e Davies (2006) a linhagem de E.coliBL21 Star (DE3) pLysS possui proteínas que também possuem afinidade por metal e constituem um desafio na purificação de proteínas heterólogas por IMAC. Essa impureza não está presente em nenhum dos géis SDS-PAGE das purificações do híbrido sem espaçador molecular, que utiliza a linhagem de E. coli M15 (Figuras 16, 18, 23 e 27).

Como neste processo a prioridade era obter uma proteína híbrida com alta pureza, apenas a fração mais pura eluída da IMAC-Sepharose, fração 3A2 (Figura 58, canaleta 7), seguiu para a Superose 12. Com isso a recuperação final absoluta foi menor que $1 \%$. O rendimento da etapa de troca aniônica também foi baixo, por volta de $22 \%$, indicando que essa etapa pode ser otimizada para gerar uma recuperação mais razoável. 
Figura 58 - SDS-PAGE e Western Blot das amostras da etapa de cromatografia de afinidade por $\mathrm{Ni}^{2+}$ da PspA94-RL-PdT.

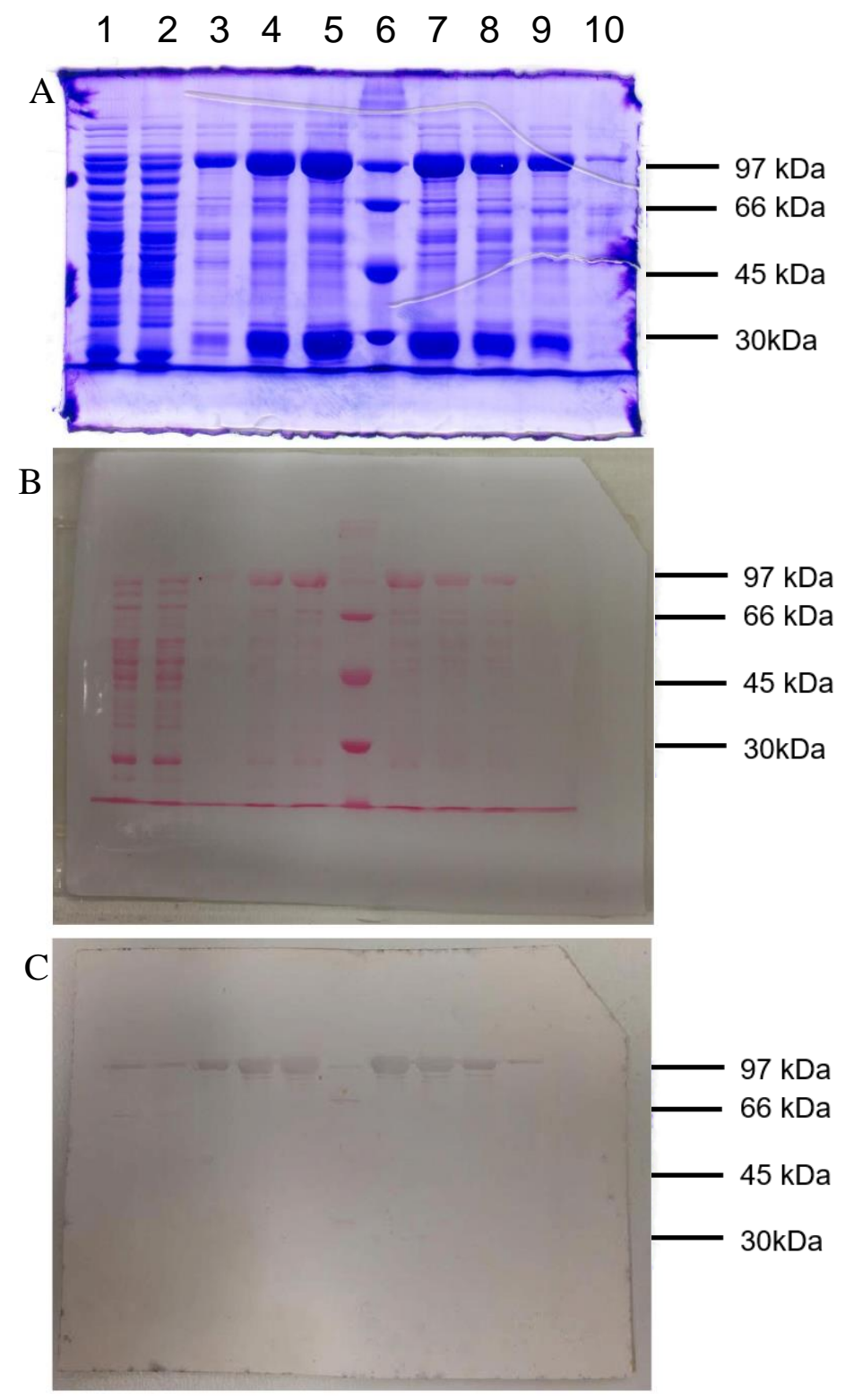

Legenda: A. Gel SDS-PAGE, B, Membrana corada com Ponceau, C. Membrana revelada com anti célula inteira de pneumococo, 1. Entrada, 2. Flowthrough e reequilíbrio, 3. Eluição fração $2 \mathrm{C} 4,4$. Eluição fração 2C5, 5. Eluição fração 3A1, 6. Padrão de massa molecular, 7. Eluição fração 3A2, 8. Eluição fração $3 A 3,9$. Eluição fração 3A4, 10, pool demais frações da eluição 


\begin{tabular}{|c|c|c|c|c|c|c|}
\hline Amostra & $\begin{array}{c}\text { Pureza } \\
\text { PspA94- } \\
\text { RL-PdT } \\
(\%)\end{array}$ & $\begin{array}{c}\text { PspA94- } \\
\text { RL-PdT } \\
\text { Total } \\
\text { (mg) }\end{array}$ & $\begin{array}{c}\text { Recuperação } \\
\text { PspA94-RL- } \\
\text { PdT } \\
\text { (Absoluta, } \\
\% \text { ) }\end{array}$ & $\begin{array}{c}\text { Recuperação } \\
\text { PspA9-RL- } \\
\text { PdT (Etapa, } \\
\%)\end{array}$ & $\begin{array}{c}\text { Fator de } \\
\text { Purificação } \\
\text { Absoluto }\end{array}$ & $\begin{array}{l}\text { Fator de } \\
\text { Purificação } \\
\text { Etapa }\end{array}$ \\
\hline Homogenato & $4 \%$ & 1077 & 100 & 100 & 1,0 & 1,0 \\
\hline $\begin{array}{c}\text { Clarificado } \\
\text { com } 0,10 \% \\
\text { CTAB } \\
\end{array}$ & $5 \%$ & 648 & 60,2 & 60,2 & 1,3 & 1,3 \\
\hline $\begin{array}{c}\text { eluição Q- } \\
\text { Sepharose } \\
200 \mathrm{mM} \mathrm{NaCl}\end{array}$ & $8 \%$ & 141 & 13,1 & 21,7 & 2,0 & 1,6 \\
\hline $\begin{array}{c}\text { pool } \\
\text { eluições } \\
\text { IMAC- } \\
\text { Sepharose }\end{array}$ & $44 \%$ & 9,97 & 0,93 & 7,09 & 11,0 & 5,5 \\
\hline $\begin{array}{c}\text { eluição } \\
\text { IMAC- } \\
\text { Sepharose } \\
\text { fração 3A2 } \\
\end{array}$ & $43 \%$ & 1,99 & 0,19 & 1,42 & 10,6 & 5,31 \\
\hline $\begin{array}{c}\text { Eluição } \\
\text { Superose } 12\end{array}$ & $95 \%$ & 1,25 & 0,12 & 62,9 & 23,5 & 2,21 \\
\hline
\end{tabular}

Tabela 14 - Processo de purificação 01 da PspA94-RL-PdT

\subsubsection{Análise da estabilidade}

As Figuras 59 a 64 apresentam os resultados da análise de estabilidade de PspA94-RL-PdT purificada como descrito no item 5.3.5. A molécula híbrida PspA94$\mathrm{RL}-\mathrm{PdT}$ se manteve íntegra por 4 semanas a $4{ }^{\circ} \mathrm{C}$. O Western Blot realizado com 8 semanas apresentou degradação da proteína armazenada a 4 ํ (Figura 62), porém a proteína armazenada a -20 ํ permaneceu íntegra até a última análise, realizada 14 meses depois da purificação (Figura 64).

É possível que o linker rígido tenha separado de maneira eficaz o domínio das duas proteínas e, com isso, as interações entre os domínios tenham dimuído a ponto de permitir que uma conformação mais próxima da natural fosse alcançada, aumentando assim a estabilidade. 
Figura 59 - Avaliação da estabilidade de PspA94-RL-PdT purificada após 1 semana de armazenamento.

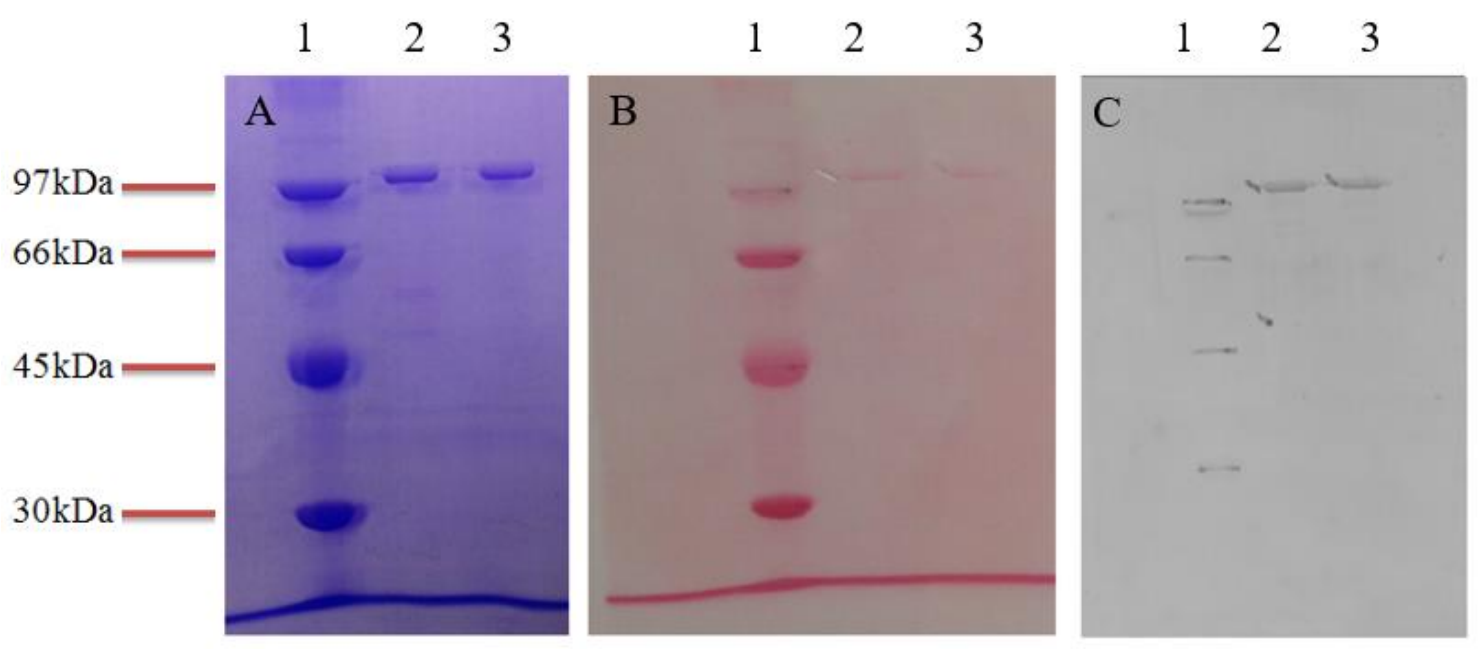

Legenda: A. SDS-PAGE, B. Membrana nitrocelulose corada com Ponceau, C. Western-Blot empregando anti célula inteira de pneumococo, 1. Padrão de massa molecular, 2. a $4^{\circ} \mathrm{C}$, 3 . a $-20^{\circ} \mathrm{C}$

Figura 60 - Avaliação da estabilidade de PspA94-RL-PdT purificada após 2 semanas de armazenamento.

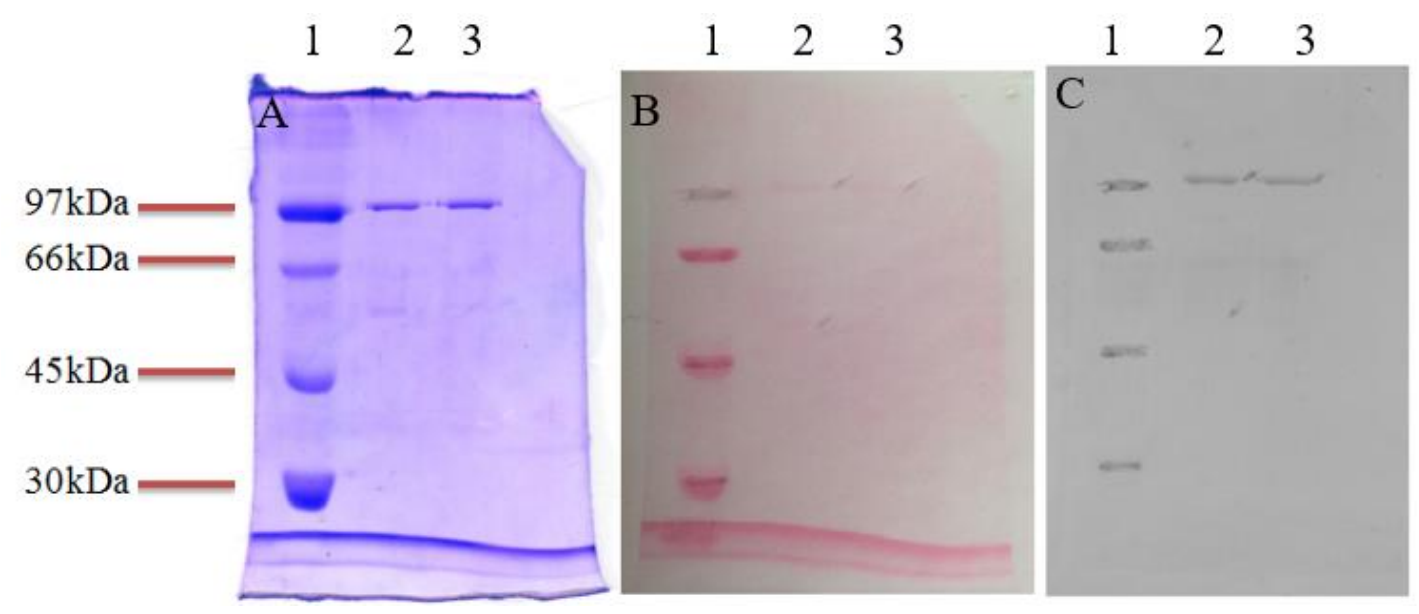

Legenda: A. SDS-PAGE, B. Membrana nitrocelulose corada com Ponceau, C. Western-Blot empregando anti célula inteira de pneumococo, 1. Padrão de massa molecular, 2. a $4^{\circ} \mathrm{C}$, 3. a $-20^{\circ} \mathrm{C}$ 
Figura 61 - Avaliação da estabilidade de PspA94-RL-PdT purificada após 4 semanas de armazenamento.

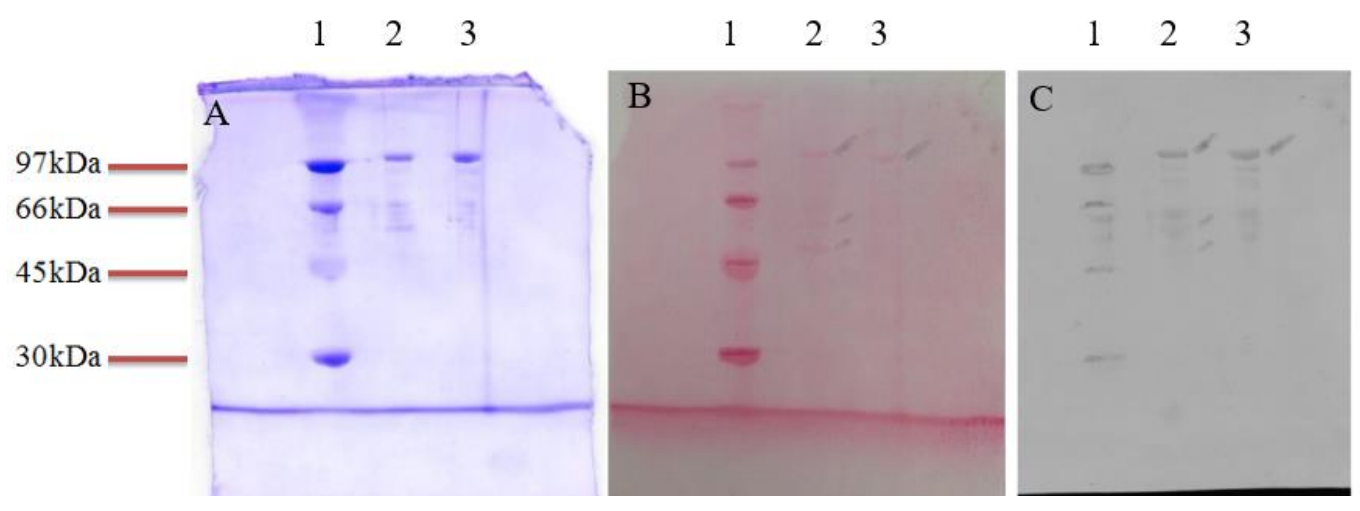

Legenda: A. SDS-PAGE, B. Membrana nitrocelulose corada com Ponceau, C. Western-Blot empregando anti célula inteira de pneumococo, 1. Padrão de massa molecular, 2. a $4{ }^{\circ} \mathrm{C}, 3$. a $-20^{\circ} \mathrm{C}$.

Figura 62 - Avaliação da estabilidade de PspA94-RL-PdT purificada após 8 semanas de armazenamento.

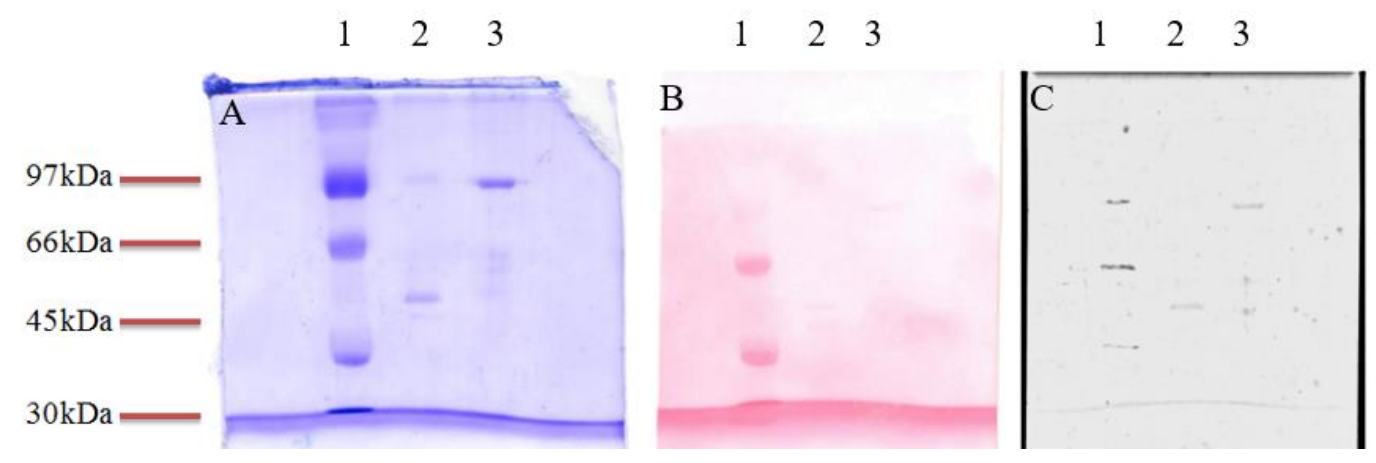

Legenda: A. SDS-PAGE, B. Membrana nitrocelulose corada com Ponceau, C. Western-Blot empregando anti célula inteira de pneumococo, 1. Padrão de massa molecular, 2. a $4{ }^{\circ} \mathrm{C}, 3$. a $-20^{\circ} \mathrm{C}$. 
Figura 63 - Avaliação da estabilidade de PspA94-RL-PdT purificada após 20 semanas de armazenamento.

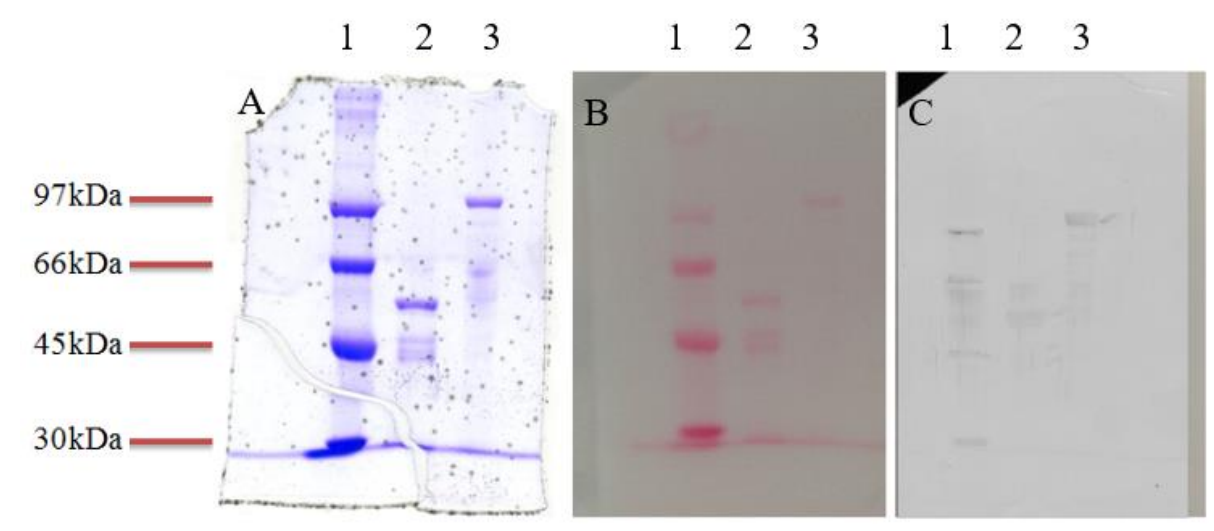

Legenda: A. SDS-PAGE, B. Membrana nitrocelulose corada com Ponceau, C. Western-Blot empregando anti célula inteira de pneumococo, 1. Padrão de massa molecular, 2. a $4{ }^{\circ} \mathrm{C}$, 3. a $-20^{\circ} \mathrm{C}$

Figura 64 - Avaliação da estabilidade de PspA94-RL-PdT purificada após 14 meses de armazenamento.

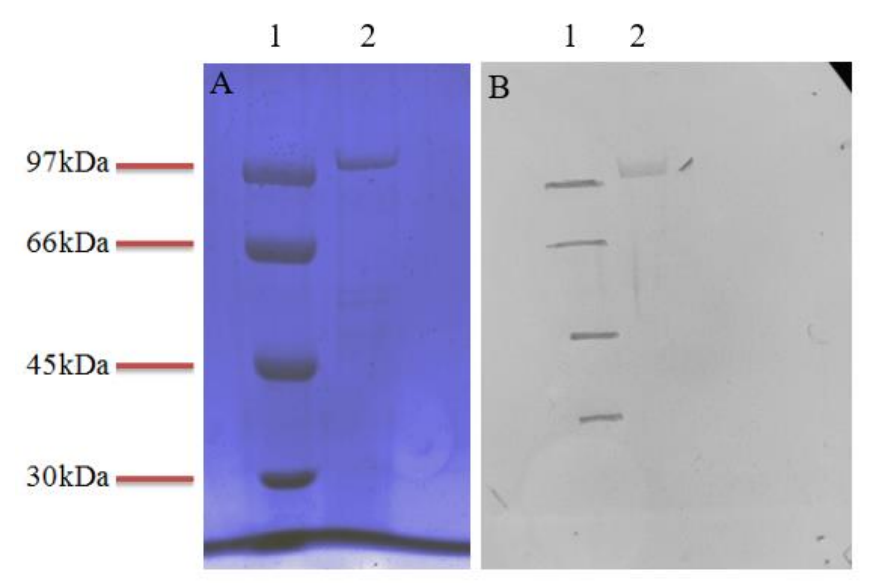

Legenda: A. SDS-PAGE, B. Membrana nitrocelulose corada com Ponceau, C. Western-Blot empregando anti célula inteira de pneumococo, 1. Padrão de massa molecular, 2. a $4{ }^{\circ} \mathrm{C}$

\subsubsection{Avaliação da influência de estabilizantes no armazenamento do híbrido PspA94-RL-PdT}

A introdução do linker rígido entre os dois antígenos foi capaz de aumentar consideravelmente a estabilidade da proteína híbrida, porém para aumentar ainda mais o seu tempo máximo de armazenamento a $4{ }^{\circ} \mathrm{C}$ alguns estabilizantes foram avaliados como excipientes: trealose, sacarose e glicerol. A Figura 65 apresenta 0 
resultado do Western Blotting realizado com 4 meses de armazenamento a $4 \stackrel{\circ}{ } \mathrm{C}$. Nesta figura é possível notar a total degradação da PspA94-RL-PdT sem estabilizantes (canaleta 2). A amostra armazenada com trealose na concentração de $2 \mathrm{~mol} / \mathrm{L}$ cristalizou a $4^{\circ} \mathrm{C}$ e não pôde ser recuperada. As amostras com 1 e $2 \mathrm{M}$ de sacarose e $25 \%$ de glicerol apresentam pequena degradação quando comparadas com o controle sem estabilizantes totalmente degradado e não foi possível detectar degradação nas amostras contendo trealose $1 \mathrm{M}$ e glicerol $50 \%$.

Figura 65 - Estabilidade da PspA94-RL-PdT a $4 \stackrel{\circ}{\circ}$ após 4 meses na presença ou ausência de estabilizantes

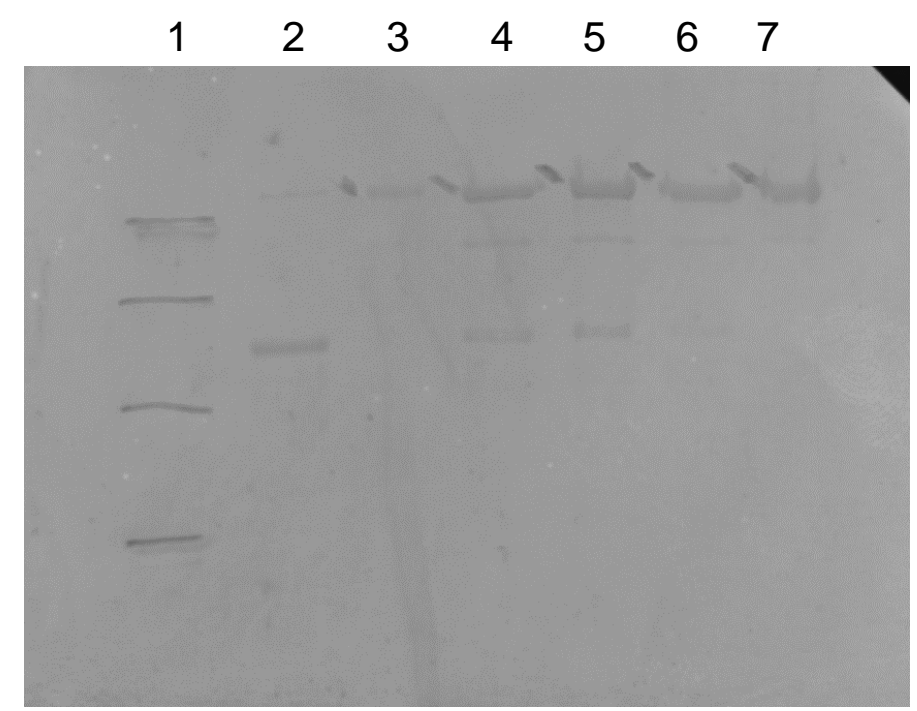

Legenda: 1. Padrão de massa molecular, 2. Sem estabilizantes, 3. Com trealose 1M, 4. Com sacarose $1 \mathrm{M}, 5$. Com sacarose $2 \mathrm{M}, 6$. Com glicerol $25 \%$, 7. Com glicerol $50 \%$.

A utilização de trealose na concentração de $1 \mathrm{M}$ e de glicerol na concentração de 50\% no armazenamento do híbrido foi capaz de, no mínimo, quadruplicar o tempo de armazenamento a $4{ }^{\circ} \mathrm{C}$ sem degradação. Além de, provavelmente, uma conformação mais conveniente ter sido alcançada graças ao espaçador rígido, a proteção adicional da trealose ou do glicerol frente à desidratação permitiu que a molécula pudesse ter um shelflife e temperatura de armazenamento plausível para ser utilizada na formulação de uma nova vacina pneumocócica proteica.

O glicerol pode causar dor e inflamação no local da injeção. Produtos com alta alta concentração de glicerol (50\%) são diluídos antes da sua administração (Van 
Metre et al., 1996). Alguns produtos injetáveis contém glicerol e são diretamente aplicados, porém com concentrações menores, por exemplo: o medicamento DHE-45 (dihidroergotamina mesilato - Novartis) usado para o tratamento de enxaqueca possui em sua formula injetável $15 \%$ de glicerol e o medicamento Propofol (diprivan - Astra Zêneca), um sedativo intravenoso, possui $22,5 \mathrm{mg} / \mathrm{mL}$ de glicerol (Strickley, 2004). A PspA-RL-PdT utilizada nas formulações vacinais se encontra na concentração de 0,1 $\mathrm{mg} / \mathrm{mL}$, conforme descrito no item 4.13 e a concentração deste híbrido neste ensaio era de $0,17 \mathrm{mg} / \mathrm{mL}$. Ao diluir a concentração de PspA-RL-PdT deste ensaio para a concentração vacinal, a concentração final de glicerol seria de aproximadamente $29,4 \%$, ainda acima das concentrações praticadas nos exemplos acima.

Já a trealose além de segura é largamente utilizada como excipiente em inúmeros produtos. Ela é eficiente na estabilização de proteínas lábeis durante sua liofilização e expostas a altas temperaturas em solução (Kaushik e Bhat, 2003). Vários produtos biotecnológicos utilizam trealose como excipiente, por exemplo: Advate (fator anti-hemofílico recombinante, Baxter Healthcare Co.) contém $10 \mathrm{mg} / \mathrm{mL}$ de trealose em sua formulação, Herceptin (Trastuzumabe - Roche) contém na sua formulação 20 $\mathrm{mg} / \mathrm{mL}$ de trealose; Avastin (Bevacizumabe - Novartis) contém $60 \mathrm{mg} / \mathrm{mL}$ de trealose e Lucentis (Ranibizumab - Novartis) contém 100 mg/mL.(Ohtake e Wang, 2011).

Todos os produtos citados acima que são comercializados atualmente e que utilizam trealose como excipiente contém essa substância em concentrações bem menores do que as avaliadas neste estudo, variando entre $0,03 \mathrm{~mol} / \mathrm{L} \mathrm{e} \mathrm{0,3} \mathrm{mol} / \mathrm{L}$. Ao juntar essa informação com o fato de a amostra armazenada com $2 \mathrm{~mol} / \mathrm{L}$ de trealose ter cristalizado, faz-se levantar a hipótese de que possivelmente uma concentração menor de trealose já seria eficiente como estabilizante. Como este excipiente tem um alto custo, é conveniente que se encontre a quantidade mínima de trealose capaz de estabilizar uma dada concentração da molécula de interesse.

\subsection{Ensaios para avaliação da resposta imunológica dos híbridos com e sem espaçador molecular entre os antígenos}

Como a proteína PspA94-PdT se mostrou instável e não foi possível purificá-la até um alto grau de pureza, ela foi produzida e purificada rapidamente, seguindo o 
protocolo simplificado do item 4.8.2, que é um protocolo que tem apenas uma etapa de cromatografia de afinidade por metal, normalmente utilizado nas fases iniciais de avaliação de antígenos. Para fins de comparação, a PspA94-RL-PdT também foi produzida e purificada da mesma maneira.

\subsubsection{Produção e purificação dos antígenos}

Como explicado anteriormente, foram produzidos e purificados híbridos especialmente para o ensaio de imunização de camundongos utilizando protocolo de purificação simplificado, conforme descrito no item 4.8.2, aqui chamado de protocolo 1.

\subsubsection{PspA94-PdT}

O cultivo de E. coli M15 carregando pQE-30/pspa94-pdT foi realizado em frasco Tunair em $1 \mathrm{~L}$ de meio LB com ampicilina e canamicina. As amostras do cultivo estão apresentadas na Figura 66. Não houve escape da expressão e a estabilidade do plasmídeo foi superior a $95 \%$.

A Figura 67 apresenta as amostras provenientes da purificação. A pureza alcançada após a cromatografia de afinidade por íons $\mathrm{Ni}^{2+}$ foi de $79 \%$. 
Figura 66 - Cultivo de E. coli M15 para produção de PspA94-PdT em meio LB-can/amp.

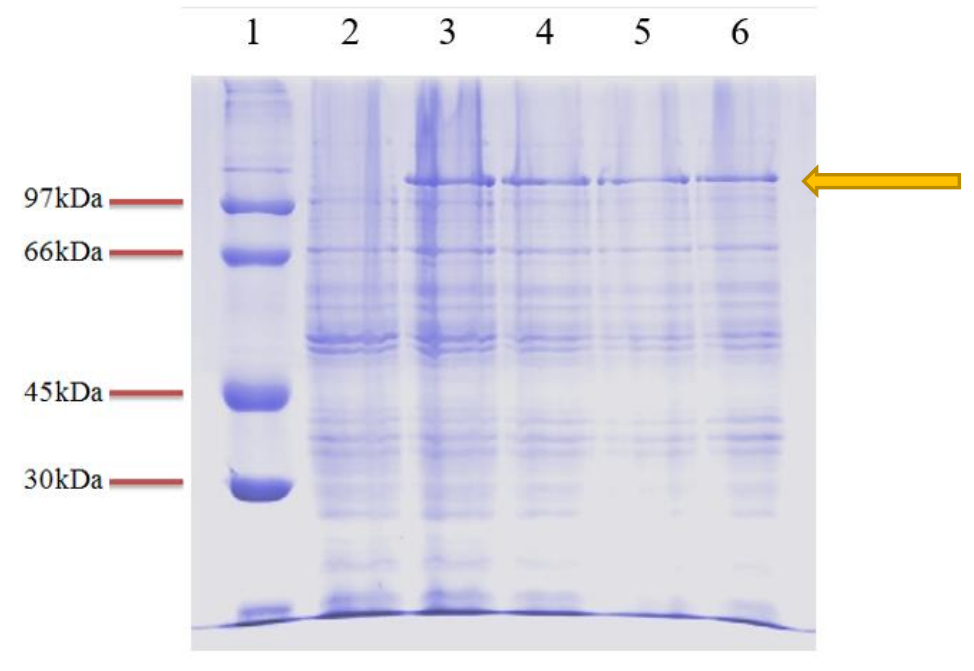

Legenda: A flecha amarela indica a PspA-PdT. 1. Padrão de massa molecular, 2. Antes indução, 3. 1 $\mathrm{h}$ após indução, 4. $2 \mathrm{~h}$ após indução,5. $3 \mathrm{~h}$ após indução,6. 4 h após indução.

Figura 67 - Purificação de PspA94-PdT empregando protocolo 1.

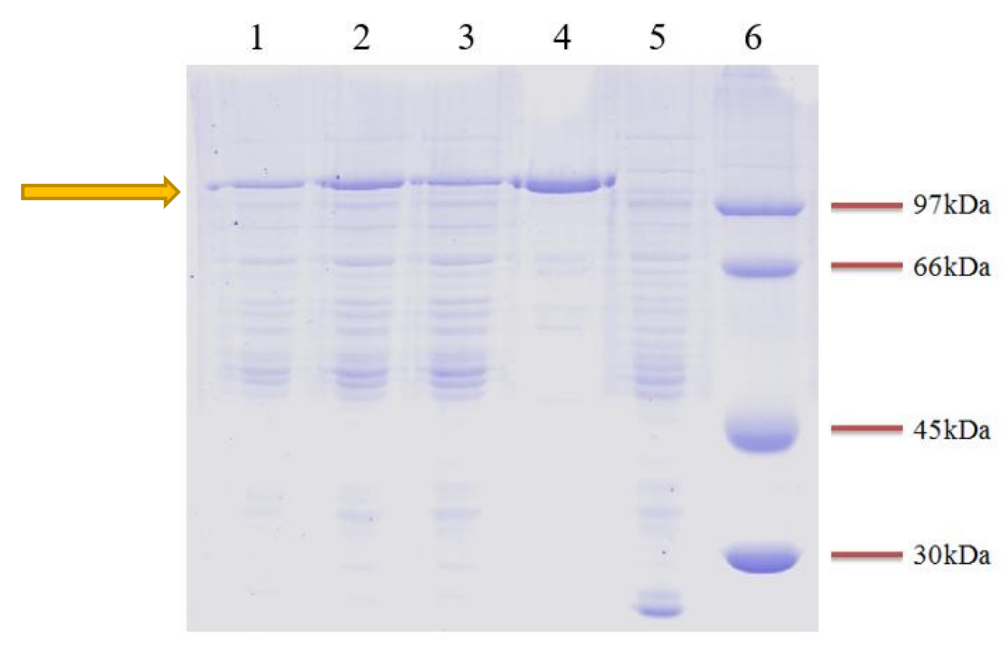

Legenda: A flecha amarela indica a PspA-PdT. 1. Homogenato, 2. Clarificado, 3. Flowthrough IMACSepharose, 5. Pool de frações de eluição - 79\% de pureza, 6. Padrão de massa molecular.

\subsubsection{PspA94-RL-PdT}

O cultivo de E. coli BL21 (DE3) para produção de PspA94-RL-PdT também foi realizado em frasco Tunair com $1 \mathrm{~L}$ de meio LB contendo canamicina. As amostras do cultivo estão apresentadas na Figura 68. Nesta construção também não houve escape da expressão e a estabilidade do plasmídeo foi de 100\%. 
A pureza alcançada com o protocolo 1 após a cromatografia de afinidade por íons $\mathrm{Ni2}+$ foi de $76 \%$. (Figura 69).

Além das proteínas produzidas acima, também fez parte dos ensaios em camundongos a PspA94-RL-PdT purificada pelo protocolo 2 desenvolvido neste trabalho, cujos resultados estão descritos no item 5.3.5 - com 95\% de pureza e mantida a $-20 \stackrel{\circ}{ } \mathrm{C}$ sem adição de estabilizantes. As doses vacinais foram preparadas com base na concentração do híbrido alcançada após a purificação, ou seja, todas continham exatamente a mesma quantidade de proteína híbrida diferindo apenas na quantidade de impurezas.

Figura 68 - Cultivo de E. coli BL21 (DE3) para produção de PspA94-RL-PdT em meio LB-can.

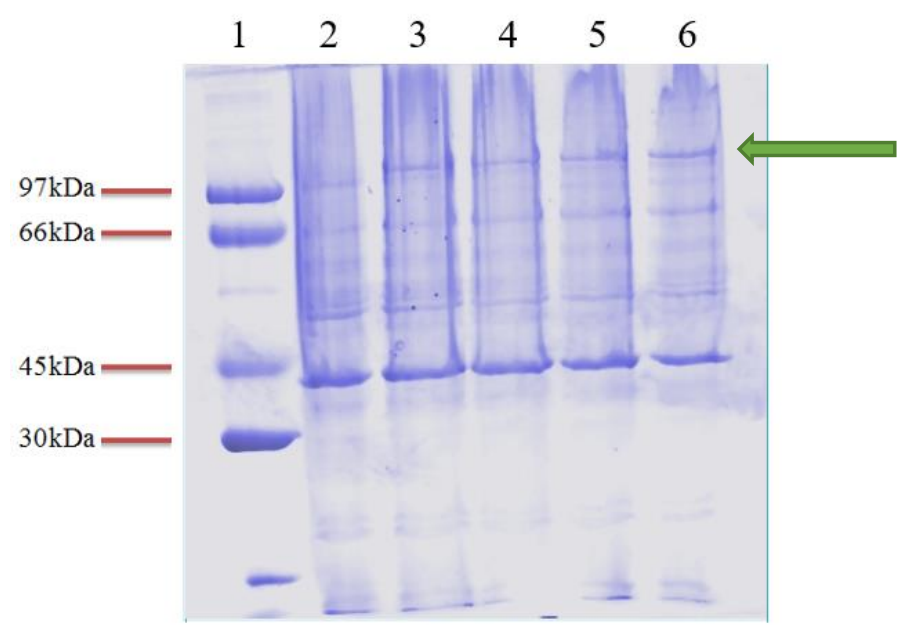

Legenda: A flecha verde indica a PspA-RL-PdT. 1. Padrão de massa molecular, 2. Antes indução, 3. 1 $\mathrm{h}$ após indução, 4. $2 \mathrm{~h}$ após indução,5. 3 h após indução,6. 4 h após indução. 
Figura 69 - Purificação de PspA94-RL-PdT empregando o protocolo 1.

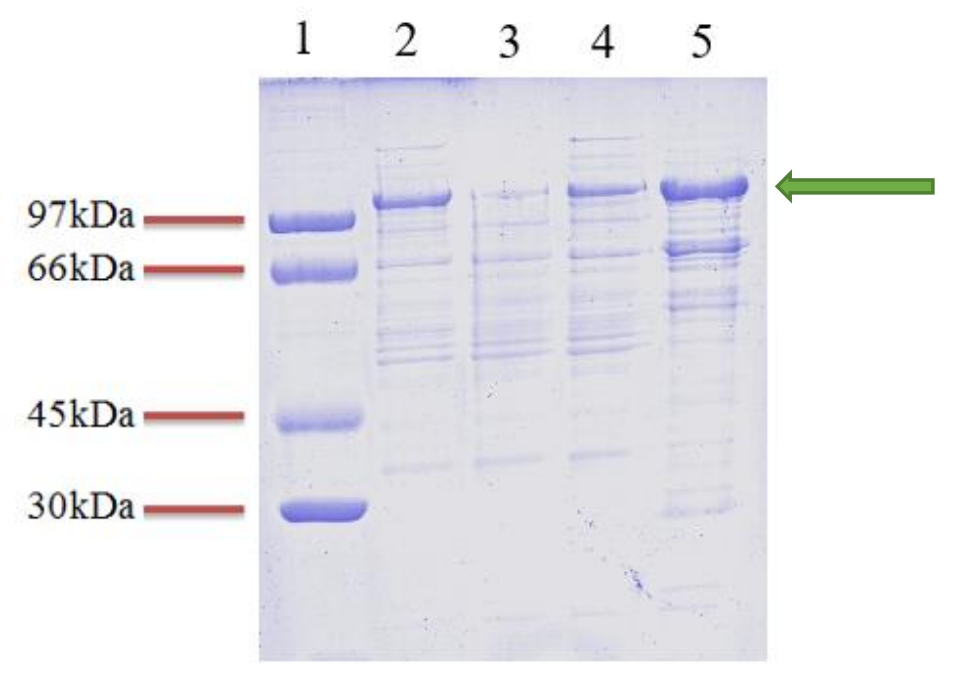

Legenda: A flecha verde indica a PspA-RL-PdT. 1. Padrão de massa molecular. 2. Homogenato, 3. Clarificado, 4. Flowthrough IMAC-Sepharose, 5. Pool de frações de eluição - 76\% de pureza

\subsubsection{Produção de anticorpos e desafio intranasal}

Estudos anteriores haviam mostrado que a proteína híbrida PspA94-PdT foi capaz de induzir altos níveis de anticorpo em camundongos e proteger os animais em desafio sistêmico (Goulart et al., 2013). Após a introdução do linker rígido para aumentar a estabilidade da molécula híbrida, fez-se necessário avaliar se a proteção deste novo híbrido seria comparável ao do híbrido sem linker. Assim, foram avaliados os títulos de lgG produzidos por 3 formulações distintas, conforme a Tabela 15.

Para o preparo das formulações, as proteínas foram diluídas em salina estéril para o correspondente a $20 \mu \mathrm{g}$ do híbrido e adsorvidos em $50 \mu \mathrm{g}$ de hidróxido de alumínio por dose. A determinação dos níveis de anticorpos produzidos em camundongos 14 dias após a primeira imunização mostrou que os animais imunizados com ambas as proteínas híbridas produziram níveis significativamente mais elevados de IgG do que o grupo controle, que recebeu apenas salina e adjuvante (Figura 70). 


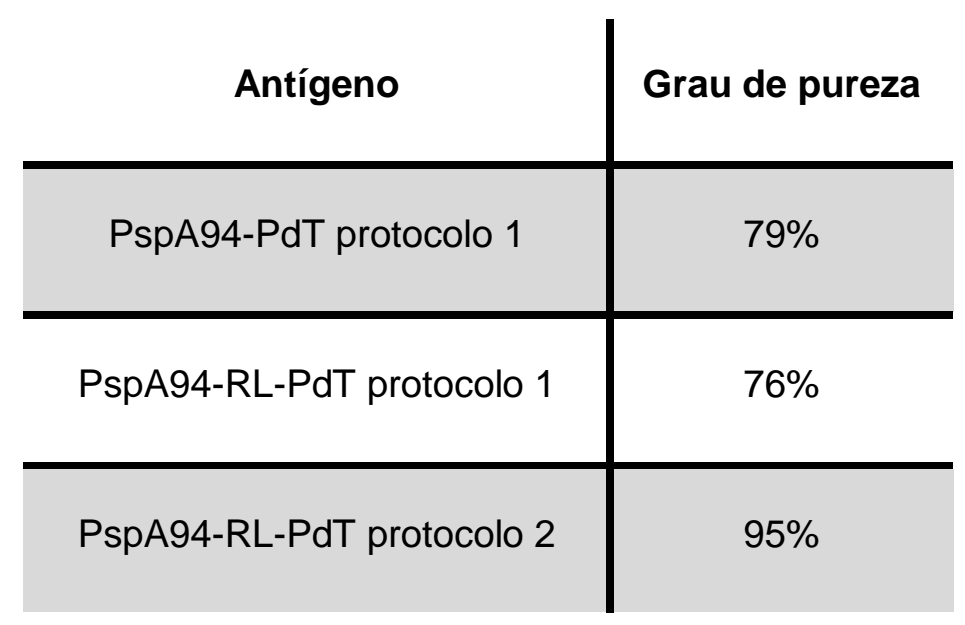

Tabela 15 - Antígenos utilizados nos ensaios de imunização de camundongos

Figura 70 - Concentração de IgG no soro dos camundongos 14 dias após $1^{\mathrm{a}}$ imunização

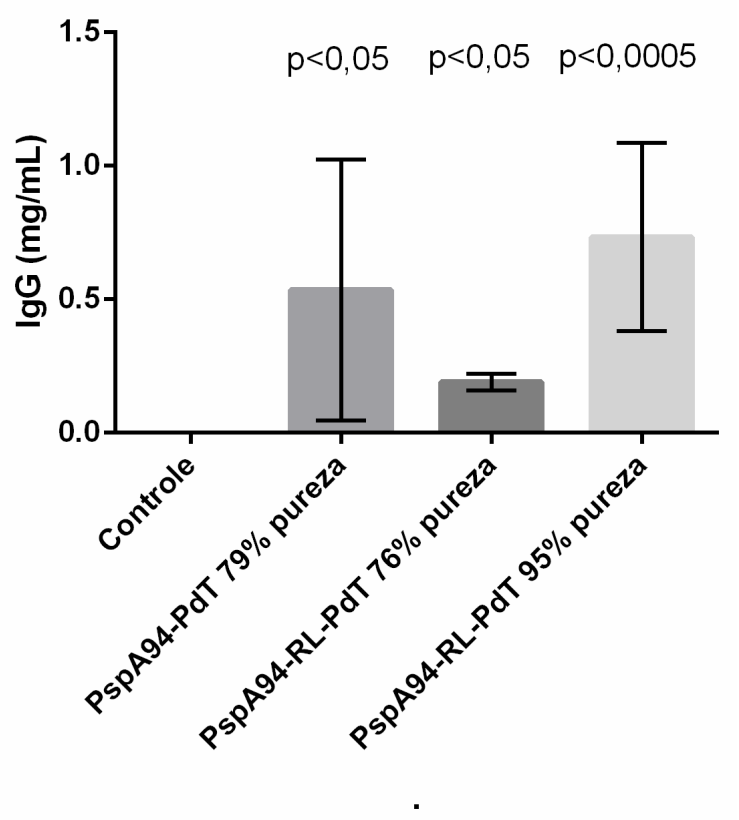

Legenda: Diferença estatística calculada em relação ao grupo controle que recebeu salina e adjuvante. As barras representam o desvio padrão de cada média

Da mesma maneira, os animais imunizados com ambas as proteínas híbridas produziram níveis significativamente mais elevados de lgG do que o controle após a segunda imunização (Figura 71). Além disso, tal como esperado, a proteína com grau de pureza mais elevado foi a que possibilitou a geração de maiores quantidades de IgG após a segunda imunização. Após a terceira dose, a produção de lgG manteve- 
se significativamente mais elevada nos grupos imunizados do que no grupo controle e diminuiu a diferença entre os níveis de anticorpos produzidos pela proteína com grau de pureza maior e pelas demais (Figura 72). Assim, foi confirmada a hipótese de que os grupos imunizados com as proteínas híbridas seriam significativamente diferentes do grupo controle.

Figura 71 - Concentração de lgG no soro dos camundongos 14 dias após 2a imunização

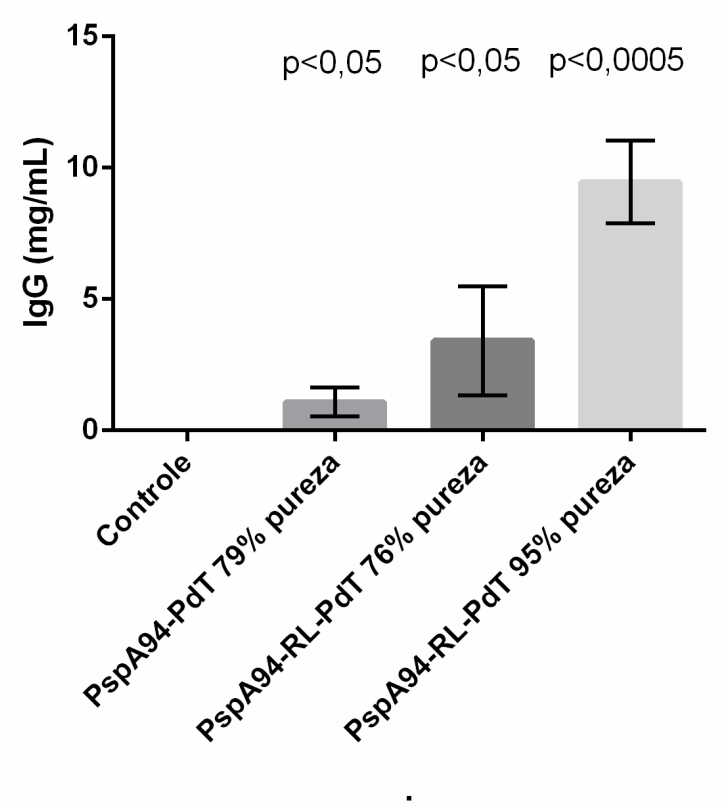

Legenda: Diferença estatística calculada em relação ao grupo controle que recebeu salina e adjuvante. As barras representam o desvio padrão de cada média 
Figura 72 - Concentração de lgG no soro dos animais 14 dias após 3a imunização.

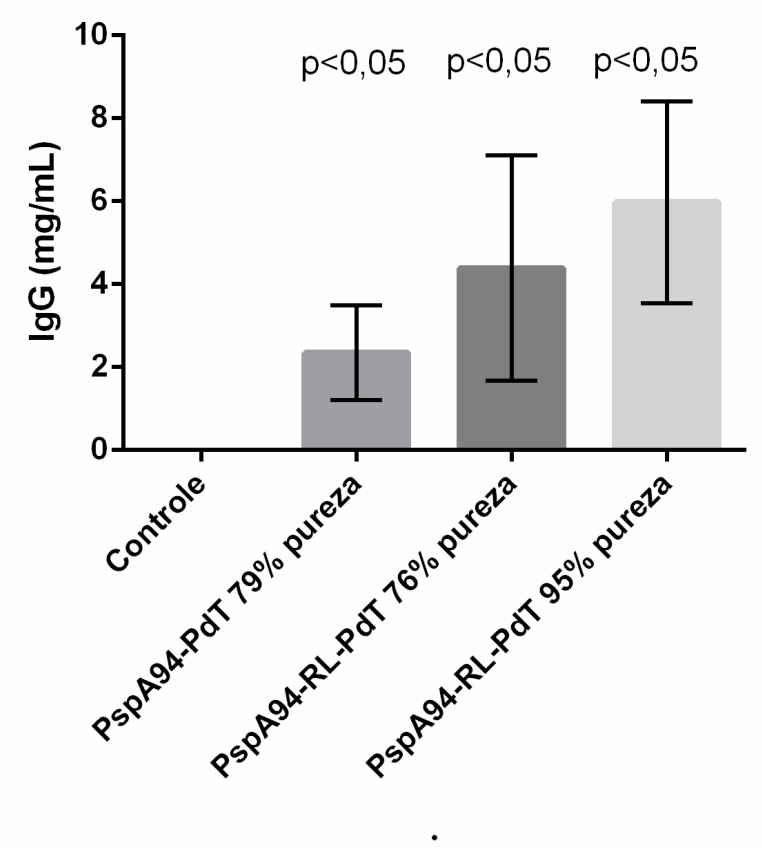

Legenda: Diferença estatística calculada em relação ao grupo controle que recebeu salina e adjuvante. As barras representam o desvio padrão de cada média

A segunda hipótese a ser verificada consistia em avaliar se as formulações com a proteína com linker rígido não eram inferiores à formulação com a proteína sem linker. Como se pode observar na Figura 73, quando comparamos os títulos de IgG após a terceira imunização, nenhum dos dois grupos imunizados com a PspA94-RLPdT foi inferior ao grupo imunizado com a PspA94-PdT. O grupo imunizado com a PspA94-RL-PdT de 95\% de pureza induziu nível superior de IgG em relação ao grupo imunizado com PspA94-PdT, enquanto não houve diferença estatística entre os grupos PspA94-PdT e PspA94-RL-PdT com grau de pureza semelhante e nem entre os grupos PspA94-RL-PdT com purezas distintas. 
Figura 73 - Concentração de lgG no soro dos camundongos após 3a imunização: comparação entre as proteínas híbridas

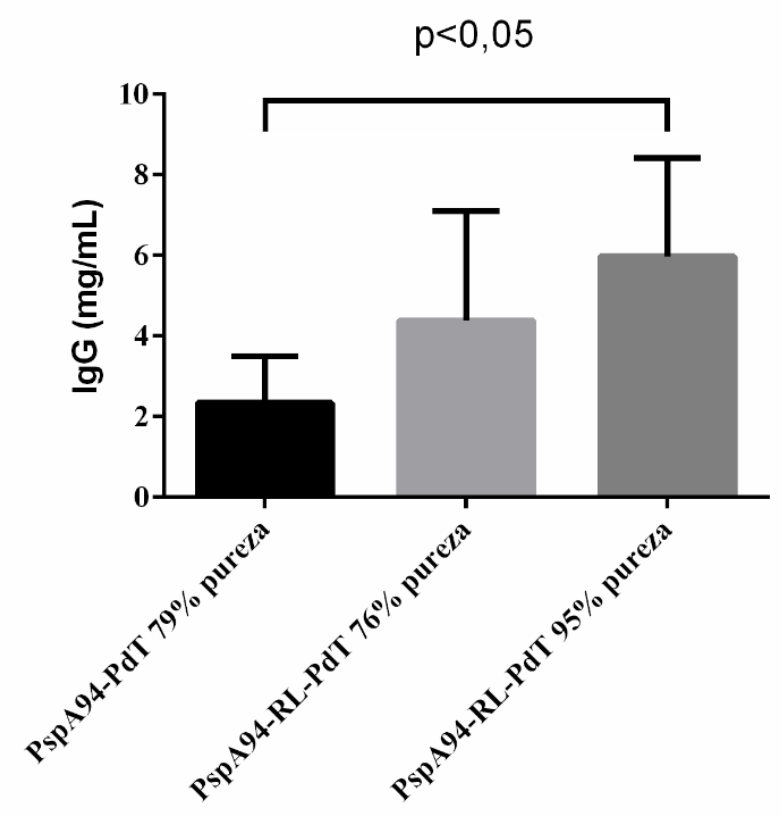

É importante notar ainda que as concentrações de $\lg G$ contra os híbridos PspA94-PdT 79\% pureza e PspA94-RL-PdT 76\% pureza aumentaram gradativamente até após a terceira imunização, enquanto que a concentração de lgG no soro dos camundongos imunizados com a PspA94-RL-PdT 95\% de pureza alcançou sua maior concentração após a segunda imunização (Figura 74), o que levanta a hipótese de que a resposta do sistema imunológico para estas proteínas é mais rápida e mais intensa quando a formulação é mais pura. 
Figura 74 - Variação da concentração média de lgG no soro dos camundongos após cada imunização

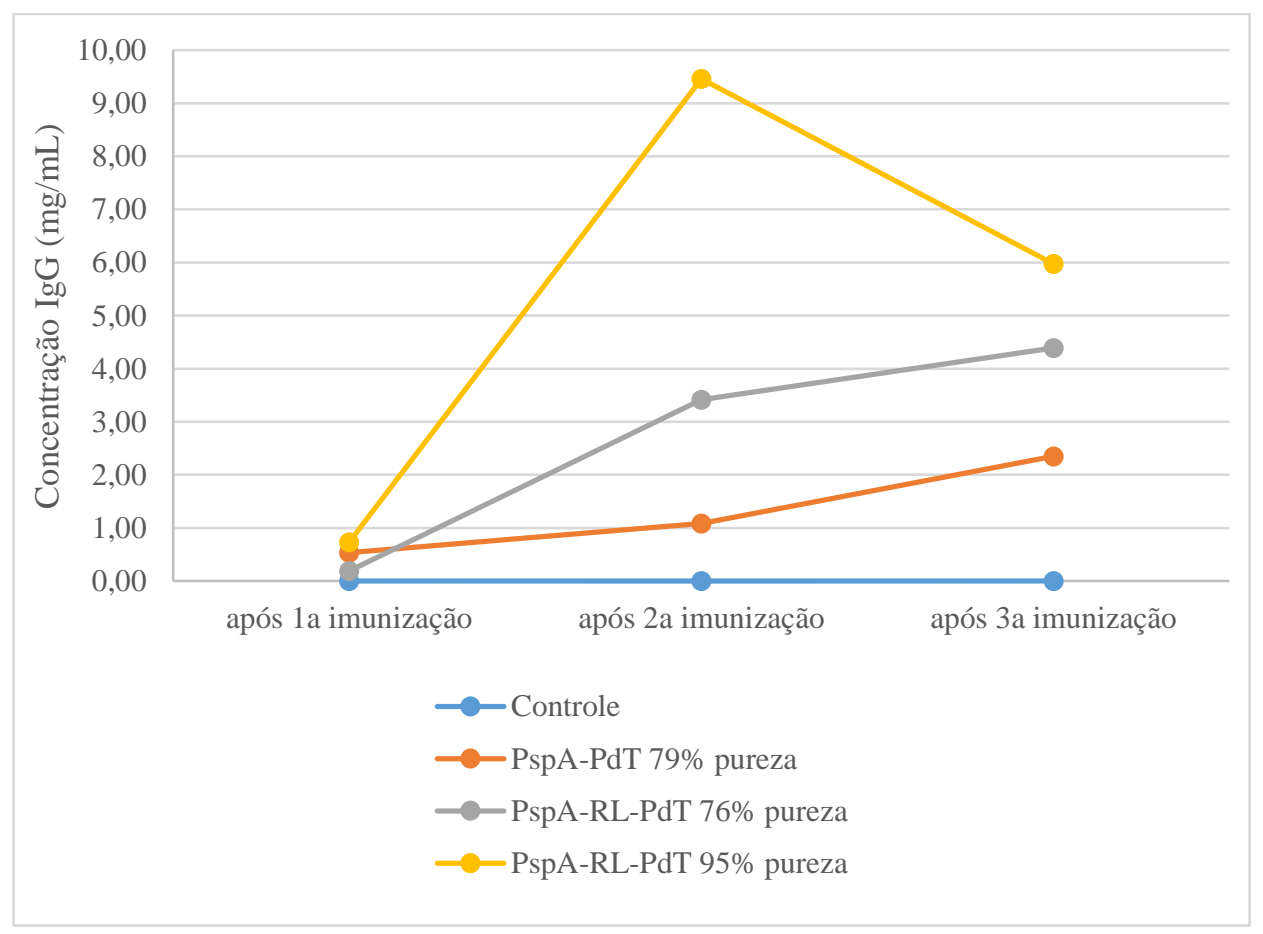

Para checar esta hipótese, as concentrações máximas de anticorpo para cada híbrido foram comparadas. A concentração máxima corresponde à concentração de IgG após a 3르 imunização para os grupos imunizados com as proteínas PspA94-PdT 79\% e PspA94-RL-PdT 76\% e após a 2ª imunização para o grupo imunizado com PspA94-RL-PdT 95\% (Figura 75). 
Figura 75 - Comparação da concentração máxima de lgG obtida após imunização com as proteínas híbridas PspA94-PdT e PspA94-RL-PdT apresentando diferentes graus de pureza

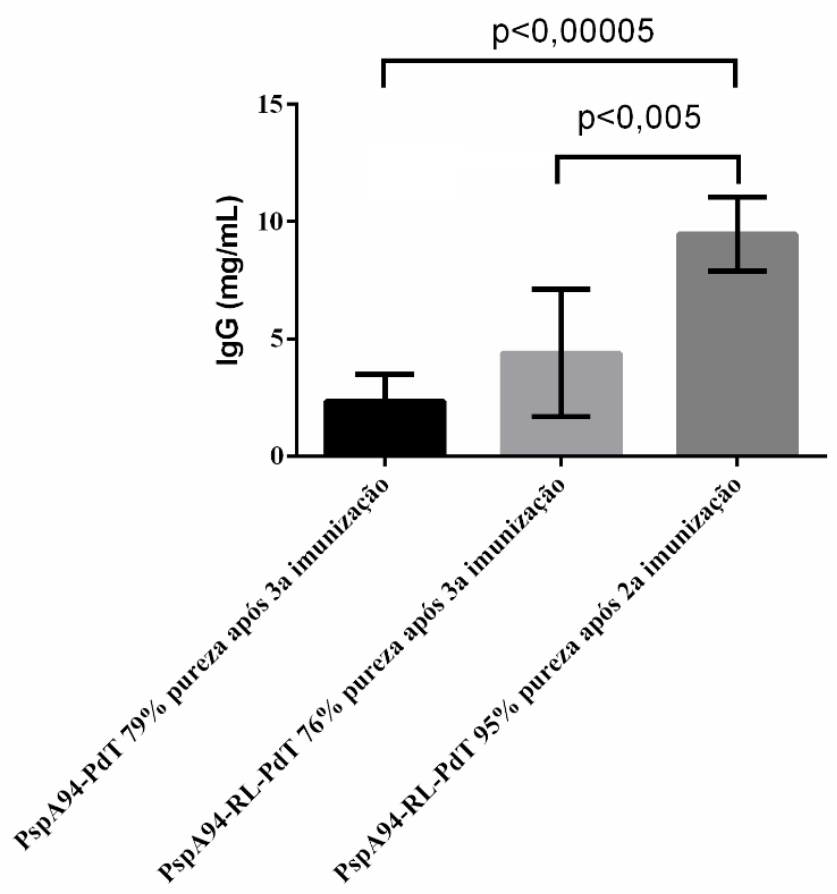

A partir da comparação das concentrações máximas de lgG alcançadas no ensaio, pode-se concluir que a imunização com o híbrido com linker rígido, PspA94RL-PdT, e pureza de 95\% induziu a produção de maiores concentrações de anticorpo (IgG total) quando comparado aos grupos com pureza menor, tanto do híbrido com linker rígido quanto do híbrido sem linker. Isso deve ocorrer porque com a formulação mais pura o sistema imune do animal está focado em produzir anticorpos quase exclusivamente contra o híbrido, já para as formulações menos puras, o sistema imune deve produzir anticorpos contra o híbrido, assim como contra as impurezas presentes.

Apesar das diferenças nas concentrações alcançadas de $\lg G$ no soro dos animais dos diferentes grupos, todas as formulações foram capazes de proteger $100 \%$ dos animais no desafio letal intranasal (Figura 76).

O híbrido com o linker rígido, além de mais estável, provou não ser inferior ao híbrido sem linker neste ensaio de imunização (com purezas semelhantes) tanto 
quanto ao resultado no desafio letal quanto ao nível de produção de anticorpos. Além disso, o híbrido com linker rígido e maior pureza induziu um nível maior de produção de anticorpos quando comparado ao híbrido sem linker $(p<0,00005)$, indicando que a pureza mais elevada pode melhorar a resposta imune em populações mais heterogêneas.

Figura 76 - Sobrevivência após desafio letal intranasal,

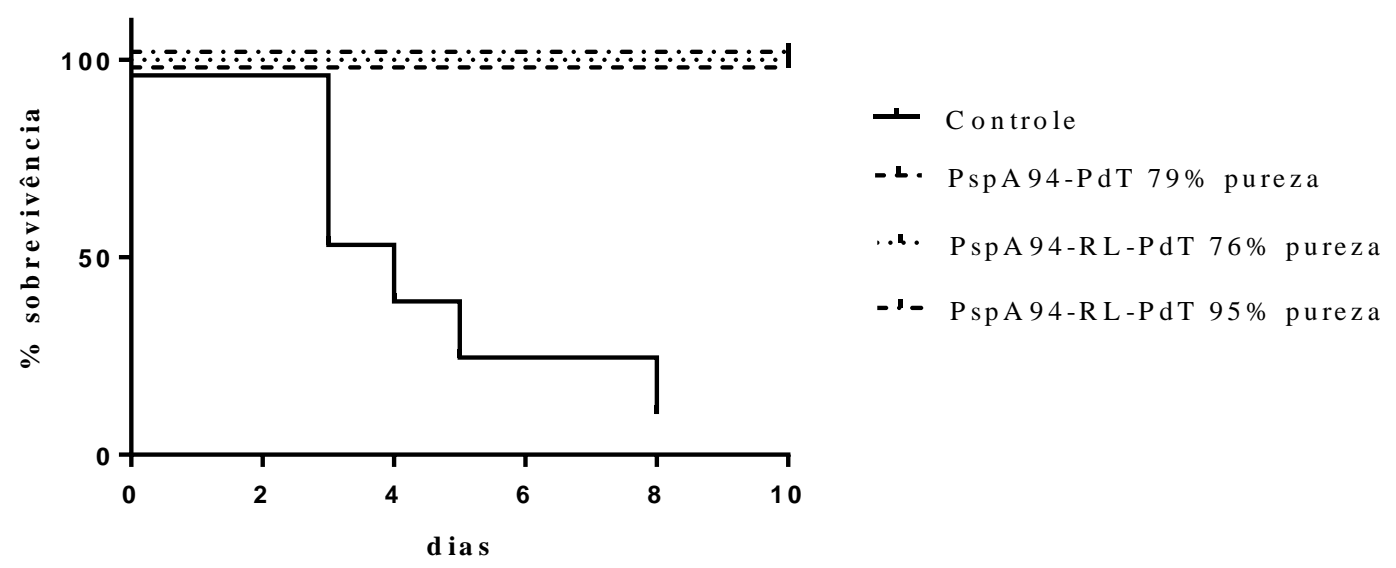

Legenda: Diferença estatística com $p<0,0001$ para todos os híbridos em relação ao grupo controle

\subsubsection{Inibição da atividade hemolítica de Ply pelo soro dos animais imunizados com os híbridos}

O soro dos animais imunizados com o híbrido sem linker - PspA94-PdT demonstrou ser capaz de inibir a atividade hemolítica da pneumolisina em estudo anterior (Goulart et al., 2013). Por isso, a capacidade do híbrido com linker rígido PspA94-RL-PdT - também foi avaliada e comparada com o híbrido sem linker.

Primeiramente, assim como para as concentrações de anticorpos, foi testada a hipótese de que a inibição da atividade hemolítica dos soros dos animais dos grupos imunizados com os híbridos fosse superior às do controle que recebeu somente salina e o adjuvante hidróxido de alumínio. A leitura da absorbância das hemácias incubadas com soro dos animais do grupo controle foi considerada como correspondendo a 
100\% de hemólise. A Figura 77 apresenta as porcentagens de hemólise residual dos grupos imunizados, que foram todas inferiores ao controle.

Figura 77 - Inibição da atividade hemolítica de Ply pelo soro dos animais imunizados com os híbridos PspA94-PdT e PspA94-RL-PdT em relação ao grupo controle, que recebeu salina e adjuvante

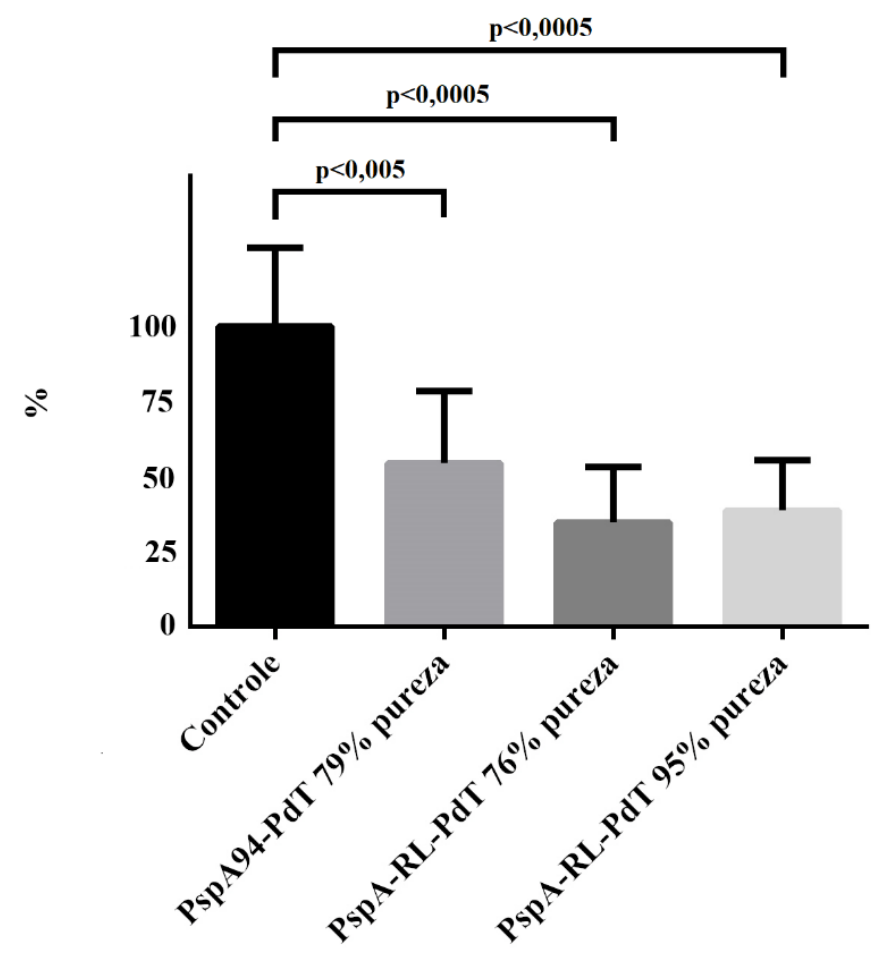

Este resultado corrobora com outros estudos que também indicam que os anticorpos produzidos contra mutantes detoxificados de pneumolisina tem um papel significativo na proteção de infecções por pneumococo, inibindo sua ação hemolítica (Salha et al., 2012; Goulart et al., 2013).

A segunda hipótese testada foi a de que haveria diferença de inibição entre os grupos imunizados com os híbridos com e sem espaçador. Para tal comparação, o grupo controle foi excluído da análise estatística. A análise mostrou que não houve diferença significativa entre a inibição da atividade hemolítica pelos soros dos animais imunizados com as diferentes formulações utilizadas no ensaio (Figura 78). A partir deste resultado pode-se concluir que a diferença entre o grau de pureza dos híbridos 
e a presença do linker rígido não afetaram a capacidade dos soros dos animais imunizados de inibir a atividade hemolítica de Ply.

Figura 78 - Comparação entre a inibição da atividade hemolítica pelos soros dos animais imunizados com os diferentes híbridos

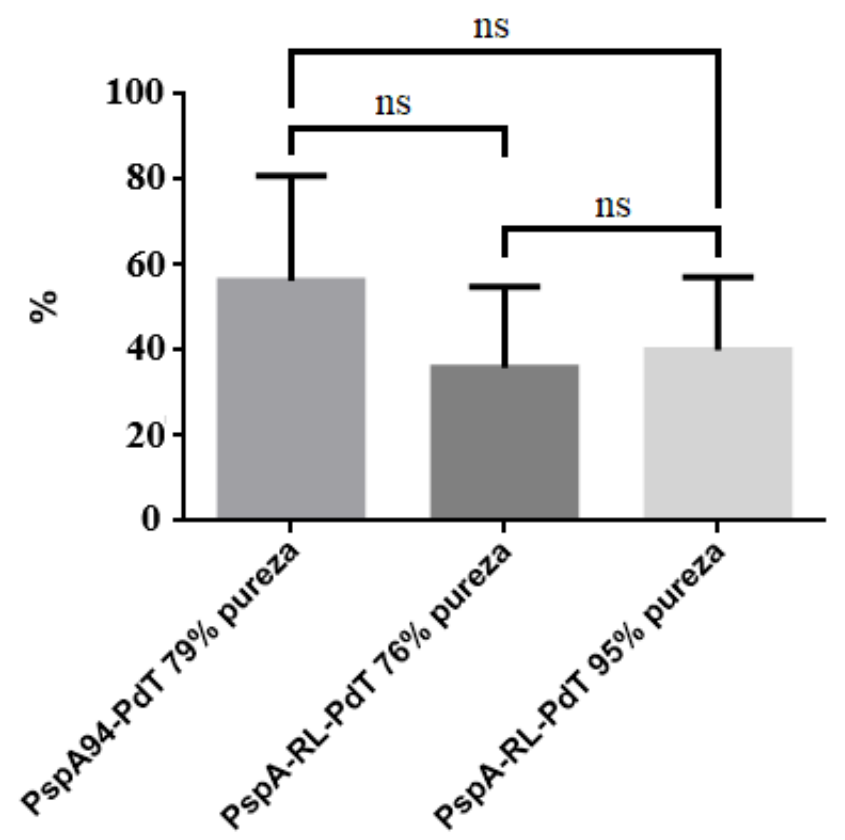




\section{DISCUSSÃO}

Este trabalho tinha como objetivo inicial desenvolver um processo robusto de purificação para o híbrido PspA-PdT, produzido em biorreator pela equipe do Departamento de Engenharia Química da UFSCar. Várias tentativas de purificação deste híbrido foram feitas, variando condições de lise, de clarificação e utilizando diferentes resinas cromatográficas. Porém, em nenhum dos processos realizados foi alcançada a mínima pureza requerida de $95 \%$ e a recuperação sempre estava muito abaixo das recuperações normalmente alcançadas na purificação de PspA de diferentes clados purificadas anteriormente no nosso laboratório: Carvalho et al. (2012) ao purificar um fragmento de PspA3 (família 2, clado 3) produzido em E. coli BL21(DE3) em biorreator utilizando glicose como fonte de carbono e empregando resinas de troca aniônica, afinidade por metal e troca catiônica, nesta ordem, ao final do processo obteve a PspA3 com $96,5 \%$ de pureza e $22 \%$ de recuperação global. Figueiredo et al. (2017) purificou a PspA4Pro (família 2, clado 4), sem cauda de histidinas, e alcançou $35,3 \pm 2,5 \%$ de recuperação e 97,8 $\pm 0,36 \%$ de pureza ao final do seu processo, que utilizou clarificação com detergente catiônico CTAB, cromatografia de troca aniônica, crioprecipitação em pH 4 e cromatografia de troca catiônica, nesta ordem. Barazzone et al. (2011) descreveu a purificação da PspA245 (família 1, clado 1) com cauda de histidina utilizando apenas duas resinas: de troca aniônica e afinidade por metal, e ao final do processo obteve a proteína na pureza de $96,6 \%$ com recuperação de $23 \%$ que, segundo os autores, ainda poderia ser otimizada mudando-se a condição de eluição da resina de afinidade por metal.

Além disso, a cada etapa de purificação do híbrido PspA-PdT foi efetuado o balanço de massas para checar a robustez do processo e dos métodos de análise. Esse balanço quase nunca pôde ser considerado plausível, já que grande parte da massa de PspA-PdT não era encontrada em nenhuma das frações. Por conta disso, muitas vezes as resinas eram submetidas a limpezas agressivas para tentar eluir alguma massa de PspA-PdT que ainda pudesse estar ligada à matriz (soluções de $\mathrm{NaOH} 0,5$ a $1 \mathrm{M}$ ou uréia 4 a $8 \mathrm{M}$ ), e tinham que ser descartadas em seguida. Mesmo assim, o híbrido não foi recuperado nessas frações de limpeza, não sendo possível fechar o balanço de massas. 
Para investigar a possibilidade de degradação deste híbrido sem espaçador, a fração F2 eluída da resina Phenyl-Sepharose, proveniente da purificação 02, foi armazenada a $4^{\circ} \mathrm{C}$ por 15 dias (Figura 19) e pôde-se notar uma mudança drástica no perfil eletroforético da amostra. Esse resultado, juntamente com o fato do balanço de massas da PspA-PdT nunca fechar, fez com que a hipótese de degradação fosse aceita.

A partir daí a causa da degradação começou a ser investigada. Uma causa comum de degradação de proteínas heterólogas em E. coli é a ação de proteases do hospedeiro (Maurizi, 1992; Murby et al., 1996; Hannig e Makrides, 1998), por isso o primeiro passo foi checar se havia na região de quebra algum sítio de protease conhecida de E. coli presente na linhagem utilizada, M15. Para isso, primeiramente foi feito Western Blot com anticorpos contra a PspA e contra a PdT, que foram capazes de reconhecer bandas distintas com aproximadamente o tamanho de ambas as proteínas, mostrando, embora com pouca precisão, que a região da quebra encontrava-se entre as duas metades do híbrido.

Assim, através de cromatografia de afinidade, foi possível separar os principais fragmentos provenientes da degradação: os fragmentos $\mathrm{N}$-terminal, que contêm a cauda de histidinas, e alguma eventual PspA-PdT inteira foram adsorvidos na resina e os fragmentos $\mathrm{C}$-terminal foram recolhidos no flowthrough. A fração não-adsorvida ainda foi purificada por HPLC em coluna $\mathrm{C} 4$ antes de ter sua sequência $\mathrm{N}$-terminal definida por degradação de Edman. O sequenciamento mostrou que a quebra ocorria principalmente exatamente entre os domínios das proteínas PspA e PdT, que haviam sido clonadas utilizando enzimas de restrição para realizar a fusão.

É importante ressaltar que o tampão de lise empregado contém inibidores de serinoproteases (PMSF) e metaloproteases (EDTA), que são as duas maiores classes de proteases da E. coli (Ehrmann, 2013), portanto também foram feitas buscas em bancos de dados para a existência de enzimas com atividades proteolíticas diferentes nas cepas de E. coli usadas. Foram utilizados de forma conjunta diversos bancos de dados disponíveis na internet - UniProt (Consortium, 2015), Ehrmann Lab - E. coli Proteases (Ehrmann, 2013) - e ferramentas de predição de sítios de clivagem por proteases baseados nesses bancos de dados, como: Merops (Rawlings et al., 2014) e Prosper (Song, J. et al., 2012), uma derivação do banco de dados Merops, para 
checar a possível presença de um sítio de clivagem de uma protease conhecida no trecho de quebra da sequência da PspA-PdT, porém não foi possível associar este trecho com a atividade de nenhuma protease conhecida de $E$. coli. A presença de uma possível atividade proteolítica nova, ainda desconhecida, foi investigada através de ensaios com digestão de caseína (Gonçalves et al., 2003), zimogramas com caseína e gelatina (Fernández-Resa et al., 1995; Leber e Balkwill, 1997; Vandooren et al., 2013) e também ensaios específicos para identificação da presença de serinoproteases e metaloproteases (Knittel et al., 2016), utilizando substratos sintetizados com essa função. Não foi identificada nenhuma protease presente nas diferentes amostras utilizadas em nenhum dos ensaios realizados.

Paralelamente à essa investigação, uma nova estratégia para a produção e purificação de uma proteína híbrida de PspA e PdT foi iniciada, baseada na remoção do principal sítio de quebra identificado no sequenciamento $\mathrm{N}$-terminal do fragmento de PspA-PdT que não se ligou à cromatografia de afinidade por metal, e na inserção de espaçadores moleculares entre os domínios das proteínas PspA e PdT.

A remoção de sítios de clivagem em proteínas de fusão já foi empregada com sucesso no trabalho de Spiegel et al. (2015), que demonstrou a otimização de uma vacina contra malária composta de uma molécula de fusão com 5 antígenos diferentes produzida em Pichia pastoris. Após a degradação da molécula ser observada nas frações de purificação, foram identificados dois sítios de clivagem através de espectrometria de massas: um deles foi relacionado a uma protease conhecida de $P$. pastoris e outro para o qual não se encontrou protease conhecida. As sequências nucleotídicas correspondentes a esses sítios de clivagem foram deletadas do gene uma a uma e então o híbrido pode ser produzido e purificado sem sofrer degradação e ação dessas proteases.

Já o trabalho de Zhao et al. (2008) mostrou uma proteína de fusão composta do fragmento $\mathrm{N}$-terminal do interferon- $\alpha 2 b$ (IFN- $\alpha 2 b$ ) com o fragmento C-terminal da albumina de soro humano (HSA), resultando no híbrido HSA-IFN- $\alpha 2 b$ que, quando foi clonada sem nenhum tipo de espaçador molecular, com as sequências justapostas, mostrou instabilidade (formação de agregados) e heterogeneidade (migração heterogênea no SDS-PAGE). Tanto a instabilidade quanto a heterogeneidade foram atribuídas à perturbação estrutural entre ambas as proteínas que compõe o híbrido. 
Para solucionar estes problemas, as proteínas foram produzidas com três espaçadores moleculares diferentes, um flexível (composto de glicinas e serinas) e dois rígidos (um composto de prolinas e alaninas intercaladas e outro com estrutura de $\alpha$-hélice). Todos os linkers com ao menos 5 aminoácidos foram capazes de aumentar a estabilidade e diminuir a heterogeneidade do híbrido, dobrando a recuperação global do processo de purificação, porém os melhores resultados foram alcançados com o linker rígido com estrutura de $\alpha$-hélice.

No momento do desenho dos espaçadores que seriam utilizados, houve uma tentativa de predizer a estabilidade das proteínas através de uma ferramenta online chamada Instability index (Expasy, 2013a). Essa ferramenta é baseada num pequeno banco de dados composto por 12 proteínas instáveis e 32 estáveis. Através da análise estatística desse banco de dados, foram definidos alguns dipeptídeos cuja ocorrência varia significativamente em proteínas estáveis e instáveis e é baseado neles que a ferramenta define se a proteína será estável ou instável. As sequências dos três híbridos foram analisadas, porém a ferramenta predisse todas as três como sendo estáveis. A limitação decorrente do pequeno banco de dados e o fato de a ferramenta analisar apenas peptídeos, e não a sequência como um todo, pode ter sido determinante no resultado que não correspondeu aos dados experimentais, pelo menos para a PspA-PdT.

A inserção do linker flexível entre as sequências da PspA e da PdT gerou um híbrido que pôde ser produzido em E. coli Rosetta (DE3) na forma solúvel, porém durante a sua purificação sofreu precipitação irreversível após descongelamento. $O$ linker flexível, ao contrário do rígido, permite alguma interação entre os domínios do híbrido, o que pode ter acarretado um enovelamento diferente e exposição de resíduos hidrofóbicos para fora da molécula, o que causa a formação de agregados e precipitação. O trabalho de Padala et al. (2010) observou um aumento da quantidade de agregados de uma proteína de fusão formada por um peptídeo fusionado com a porção Fc de um anticorpo após um processo de congelamento e descongelamento com parâmetros não controlados e sugere que esse impacto é menor quando os parâmetros de processo de congelamento e descongelamento são controlados, como por exemplo decaimento da temperatura no tempo, volume, área superficial da embalagem. 
Já o linker rígido foi capaz de separar os domínios da PspA-RL-PdT e essa molécula pode ser produzida tanto em E. coli BL21 (DE3) quanto em E. coli BL21 Star (DE3) pLysS na forma solúvel e purificada até a pureza de $95 \%$. Vale ressaltar aqui que, tal como observado por Spiegel et al. (2015) para o antígeno para malária, a estabilidade foi fundamental para que o grau de pureza requerido fosse alcançado.

Apesar de ter sido produzido com sucesso em biorreatores, a produtividade do híbrido PspA-RL-PdT foi baixa quando comparada com a de outras moléculas de PspA anteriormente produzidas pelo grupo (Barazzone et al., 2011; Carvalho et al., 2012; Figueiredo et al., 2017).

Segundo (Demain e Vaishnav, 2009), a E. coli tem dificuldade para produzir de forma eficiente proteínas com tamanho igual ou maior a $100 \mathrm{kDa}$. Como a molécula híbrida tem praticamente o dobro do tamanho da PspA, aproximadamente $90 \mathrm{kDa}$, além de alguns códons raros em E. coli, é justificável que a sua produção seja mais complexa e a produtividade seja menor. Para aumentar a produtividade uma possibilidade é trabalhar na otimização dos códons da sua sequência, bem como em testes de produção em outras linhagens de E. coli, como a Rosetta, uma vez que ela possibilitou a produção do híbrido com linker flexível, que havia sido sintetizado de forma truncada em BL21(DE3). Além disso, outras estratégias de cultivo e de controle no biorreator, como por exemplo cultivos semi-contínuos (Jensen e Carlsen, 1990; Yee e Blanch, 1992; Kotik et al., 2004), contínuos (Lee et al., 1989) ou com meio de auto-indução poderiam ser avaliadas (Fox e Blommel, 2009).

A PspA-RL-PdT permaneceu estável por 1 mês a $4{ }^{\circ} \mathrm{C}$ sem estabilizantes e por no mínimo 14 meses a $-20 \stackrel{\circ}{\circ}$. Para aumentar ainda mais sua estabilidade sem a necessidade de congelamento, alguns excipientes foram avaliados. A PspA-RL-PdT na concentração de $0,17 \mathrm{mg} / \mathrm{mL}$ permaneceu estável por 4 meses na presença de trealose $1 \mathrm{M}$ ou glicerol $50 \%$. A concentração de trealose pode ser ainda otimizada em estudos futuros, já que nenhuma concentração abaixo de $1 \mathrm{M}$ foi avaliada. Como a trealose é um excipiente de alto custo, é conveniente achar a mínima concentração de trealose capaz de aumentar a estabilidade de uma dada concentração de PspARL-PdT. A trealose age formando uma camada protetora na superfície da proteína e existe um limite de quantidade de trealose com o qual cada molécula de proteína pode 
interagir (Wang, 1999), portanto qualquer quantidade de trealose excedente não estaria cooperando para a estabilização do híbrido.

Uma vez que o híbrido sem espaçador não poderia ser purificado até uma pureza semelhante à PspA-RL-PdT (95\%), ele foi produzido e purificado utilizando o protocolo simplificado, comumente utilizado em laboratórios de biologia molecular para análise inicial de antígenos em ensaios com camundongos. Esse protocolo simplificado é muito mais curto e pode ser realizado em um único dia, ao contrário da purificação mais robusta realizada com a PspA-RL-PdT chamada de protocolo 2. Nesse protocolo a única etapa cromatográfica utilizada após a clarificação é a cromatografia de afinidade por metais. O estudo de Bolanos-Garcia e Davies (2006) mostrou que esse tipo de cromatografia apresenta limitações importantes, já que a maioria das linhagens comerciais de $E$. coli apresentam várias proteínas que, assim como a cauda de histidinas da proteína de interesse, também possuem afinidade por quelatos de metal. Essas proteínas são, na sua maioria, enzimas produzidas em grande quantidade como resposta à expressão da proteína heteróloga. Com isso, essas proteínas são co-purificadas juntamente com a proteína de interesse, o que limita $\circ$ fator de purificação desta etapa e, consequentemente, deste tipo de purificação.

O protocolo simplificado gerou uma PspA-PdT com $79 \%$ de pureza. Esse híbrido foi produzido, purificado e, menos de 48 horas depois, já foi utilizado como primeira dose nos experimentos para avaliação da resposta imune dos camundongos BALB/c. Para poder avaliar a influência da pureza do antígeno, a PspA-RL-PdT também foi purificada seguindo este mesmo protocolo simplificado, que resultou numa pureza de $76 \%$.

No ensaio de avaliação de resposta imune em camundongos foram avaliadas três formulações diferentes, todas com $20 \mu \mathrm{g}$ de proteína híbrida e $50 \mu \mathrm{g}$ de hidróxido de alumínio como adjuvante, além do controle que só recebeu adjuvante com salina: uma formulação contendo PspA-PdT com pureza de 79\%; uma formulação contendo PspA-RL-PdT coom 76\% de pureza; e, por fim, uma outra formulação também contendo PspA-RL-PdT, porém com pureza de $95 \%$. O objetivo deste experimento foi dividido em duas hipóteses distintas: a primeira, de que as formulações avaliadas eram superiores ao controle quanto à indução na produção de anticorpos e a segunda, 
de que a proteína PspA-RL-PdT não era inferior à proteína PspA-PdT - sem espaçador - na estimulação do sistema imune.

Resultados anteriores mostraram que a PspA-PdT foi capaz de induzir altos níveis de lgG em camundongos, inclusive superiores à simples combinação desses antígenos em moléculas distintas (Goulart et al., 2013). Após a inserção do linker, era preciso checar se o híbrido ainda apresentaria essa capacidade, ou seja, verificar se o espaçador rígido não iria de alguma forma atrapalhar a resposta imune do híbrido.

A primeira hipótese foi confirmada, todos as formulações induziram produção de anticorpos significativamente maiores do que no grupo controle. A segunda hipótese também foi confirmada: as formulações com PspA-RL-PdT não foram inferiores à formulação contendo PspA-PdT, ou seja, o linker não influenciou negativamente a produção de anticorpos pelos camundongos. Porém, a formulação com pureza semelhante (PspA-RL-PdT 76\%) induziu resposta estatisticamente igual à formulação de PspA-PdT, enquanto que a formulação com PspA-RL-PdT com 95\% de pureza foi superior às outras duas. Esses resultados mostram que o espaçador molecular também não influenciou de modo positivo a produção de anticorpos. Assim, o que fez o título de anticorpo ser maior neste grupo foi a alta pureza de 95\% da PspARL-PdT.

Esses resultados mostram que o grau de pureza é fator determinante para a correta avaliação da resposta imune deste híbrido. Como as análises primárias de antígeno utilizam de um protocolo de purificação que não alcança esse grau de pureza maior ou igual a 95\%, ou não se identificam as impurezas devido às baixas concentrações proteicas envolvidas, existe a possibilidade de esse tipo de experimento não ser capaz de detectar um potencial antigênico presente. Além disso, como nesta fase inicial os antígenos são produzidos e purificados em escala muito pequena, os experimentos são feitos rapidamente e, por isso, não são capazes de detectar problemas de instabilidade que inviabilizariam trabalhos futuros com a mesma molécula.

Desafios como esses são decorrentes do aumento de escala de produção. Em escalas menores, além de alguns problemas não serem detectados, as etapas de produção das proteínas não desafiam as etapas de purificação que se sucedem, já que a produtividade é baixa e a preocupação com a recuperação normalmente está 
ausente. Quando as moléculas candidatas a compor um fármaco se encontram numa fase mais avançada de desenvolvimento, elas passam a ser produzidas em escala piloto. Nesta escala, a pureza final e a recuperação são os fatores que determinam o sucesso do processo de purificação. As impurezas que estão presentes em menor quantidade e que possuem alguma similaridade estrutural com a proteína de interesse costumam ser separadas nas últimas etapas dos processos de purificação. São essas etapas que constituem um grande desafio para a indústria de bioprocesso (Saraswat et al., 2013). A otimização das linhagens de E. coli utilizadas e as características dos vetores de expressão modernos, juntamente com estratégias otimizadas de produção em biorreatores aumentaram muito a produtividade na etapa de upstream. Porém, segundo Azevedo et al. (2009), as etapas de downstream não tiveram tantas modernizações nas últimas décadas e, por isso, não acompanharam essas melhoras na mesma velocidade, o que causou um gargalo nos bioprocessos. Para contornar este problema, atualmente mais esforços estão sendo empregados no desenvolvimento e otimização dos processos de purificação. Esses incluem resinas mistas ou mixed-mode resins, que combinam dois princípios de separação em uma única matriz (Saraswat et al., 2013) e cromatografia em membranas de uso único (Deshmukh et al., 2000; Knudsen et al., 2001). Portanto, apesar de o problema da estabilidade do híbrido ter sido resolvido, ainda há um longo caminho a percorrer a fim de se estabelecer a um processo robusto para produção e purificação da PspA-RL$\mathrm{PdT}$, para o qual este trabalho contribuiu de maneira relevante, senão para solucionar todos, ao menos para apontar os principais gargalos a serem solucionados. 


\section{CONCLUSÕES}

A construção da proteína híbrida PspA94-PdT sem espaçador, que esse trabalho se propôs inicialmente a purificar, não se mostrou estável. Essa instabilidade, que não foi resultante de degradação proteolítica, não permitiu a sua purificação em escala de bancada ao grau requerido para uso em vacinas e, com isso, inviabilizou a sua utilização posterior.

Através de Western Blot da proteína degradada e sequenciamento da porção $\mathrm{N}$-terminal do fragmento que não adsorveu na IMAC-Sepharose, pois esta construção foi obtida com His-tag $\mathrm{N}$-terminal, foi possível determinar que a ruptura ocorreu principalmente entre as duas proteínas. Para superar este obstáculo foi proposta a construção de novos híbridos sem o sítio de clivagem identificado no híbrido degradado e com espaçadores moleculares entre as proteínas.

A construção em E. coliBL21(DE3) Rosetta contendo pET-28a/pspA94-FL-pdT permitiu a produção da proteína híbrida íntegra na forma solúvel. Porém, houve uma precipitação irreversível quando a proteína já purificada foi descongelada. Todas as tentativas de ressolubilização fracassaram e as análises subsequentes não puderam ser concluídas.

A proteína híbrida com espaçador molecular rígido PspA94-RL-PdT foi produzida, purificada e a análise de sua estabilidade revelou que a proteína se manteve íntegra por 4 semanas a $4^{\circ} \mathrm{C}$ e por pelo menos 14 meses a $-20^{\circ} \mathrm{C}$. Com isso, conclui-se que a deleção do sítio de clivagem identificado no fragmento da PspA94PdT degradada e a inserção do espaçador molecular rígido, juntamente com a retirada da última porção da região de prolinas da PspA94 foram capazes de aumentar consideravelmente a estabilidade, o que, consequentemente, permitiu a obtenção do híbrido com maior pureza. A estabilidade pôde ser ainda melhorada com a adição de $1 \mathrm{M}$ de trealose, o que fez com que a proteína permanecesse íntegra por pelo menos 4 meses a $4 \stackrel{\circ}{\circ}$.

Os ensaios em camundongos permitiram concluir que a inserção do linker rígido não afetou a resposta imune antes verificada para o híbrido sem linker. Concentrações semelhantes de anticorpos foram obtidas por ambos os híbridos e a formulação mais 
pura, com a PspA94-RL-PdT, induziu concentrações maiores de anticorpos com uma dose a menos, o que indica que a obtenção de uma molécula estável que possa ser purificada a elevado grau de pureza tem papel essencial para garantir a eficiência da resposta imune em populações mais heterogêneas.

Além disso, todas as formulações foram capazes de proteger $100 \%$ dos animais imunizados contra o desafio intranasal com uma cepa virulenta de pneumococo e os anticorpos dos animais dos 3 grupos imunizados com os híbridos foram capazes de inibir a atividade hemolítica da Ply em níveis semelhantes. Com isso, conclui-se que a PspA94-RL-PdT apresentou resposta imune não inferior à obtida anteriormente para a PspA94-PdT em ensaios em animais e que a inclusão do espaçador aumentou a estabilidade da molécula de modo a permitir sua produção e purificação em larga escala.

Apesar de a produção em bioreator ter sido suficiente para obter os resultados apresentados neste trabalho, é importante notar que a produção desta molécula em biorreator deverá, em estudos posteriores, ser otimizada de forma a maximizar a expressão e aumentar a produtividade. Dessa forma, será possível avaliar melhor a viabilidade econômica desta proposta. 


\section{REFERÊNCIAS BIBLIOGRÁFICAS*}

AMGEN. Enbrel (Etanercept) full prescribing information. California, USA, 2015. Disponível em: < http://pi.amgen.com/united states/enbrel/derm/enbrel pi.pdf >. Acesso em: 01/03/2016.

ARAI, R. et al. Design of the linkers which effectively separate domains of a bifunctional fusion protein. Protein Eng, v. 14, n. 8, p. 529-32, Aug 2001. ISSN 02692139. Disponível em: < http://www.ncbi.nlm.nih.gov/pubmed/11579220 >.

ARAI, R. et al. Conformations of variably linked chimeric proteins evaluated by synchrotron X-ray small-angle scattering. Proteins, v. 57, n. 4, p. 829-38, Dec 2004. ISSN 1097-0134. Disponível em: < http://www.ncbi.nlm.nih.gov/pubmed/15390267 >.

ARAKAWA, T. et al. Factors affecting short-term and long-term stabilities of proteins. Adv Drug Deliv Rev, v. 46, n. 1-3, p. 307-26, Mar 2001. ISSN 0169-409X. Disponível em: < http://www.ncbi.nlm.nih.gov/pubmed/11259845 >.

ASENJO, J. A.; ANDREWS, B. A. Protein purification using chromatography: selection of type, modelling and optimization of operating conditions. J Mol Recognit, v. 22, n. 2, p. 65-76, 2009 Mar-Apr 2009. ISSN 0952-3499. Disponível em: < http://www.ncbi.nlm.nih.gov/pubmed/18546092 >.

AZEVEDO, A. M. et al. Chromatography-free recovery of biopharmaceuticals through aqueous two-phase processing. Trends Biotechnol, v. 27, n. 4, p. 240-7, Apr 2009. ISSN 0167-7799. Disponível em: < https://www.ncbi.nlm.nih.gov/pubmed/19251328 >.

BALSELLS, E. et al. Serotype distribution of Streptococcus pneumoniae causing invasive disease in children in the post-PCV era: A systematic review and metaanalysis. PLoS One, v. 12, n. 5, p. e0177113, 2017. ISSN 1932-6203. Disponível em: $<$ https://www.ncbi.nlm.nih.gov/pubmed/28486544 >.

BARAZZONE, G. C. et al. Production and purification of recombinant fragment of pneumococcal surface protein A (PspA) in Escherichia coli. Procedia in Vaccinology, v. 4, n. 4th Vaccine and ISV Annual Global Congress, p. 27-35, 2011. ISSN 1877282X. Disponível em:

http://www.sciencedirect.com/science/article/pii/S1877282X11000063 >.

BAROCCHI, M. A.; CENSINI, S.; RAPPUOLI, R. Vaccines in the era of genomics: the pneumococcal challenge. Vaccine, v. 25, n. 16, p. 2963-73, Apr 2007. ISSN 0264410X. Disponível em: < http://www.ncbi.nlm.nih.gov/pubmed/17324490 >.

BEALL, B. et al. Pneumococcal pspA sequence types of prevalent multiresistant pneumococcal strains in the United States and of internationally disseminated clones. J Clin Microbiol, v. 38, n. 10, p. 3663-9, Oct 2000. ISSN 0095-1137. Disponível em: $<$ http://www.ncbi.nlm.nih.gov/pubmed/11015380 >.

*De acordo com:ASSOCIAÇÃO BRASILEIRA DE NORMAS TÉCNICAS. NBR 6023: informação e documentação: referências: elaboração. Rio de Janeiro, 2002. 24 p. 
BERRY, A. M. et al. Effect of defined point mutations in the pneumolysin gene on the virulence of Streptococcus pneumoniae. Infect Immun, v. 63, n. 5, p. 1969-74, May 1995. ISSN 0019-9567. Disponível em: < http://www.ncbi.nlm.nih.gov/pubmed/7729909 >.

BOBROVNIK, S. A.; DEMCHENKO, M. A.; KOMISARENKO, S. V. FUNDAMENTAL DIFFERENCES BETWEEN NATURAL ANTIBODIES AND POLYREACTIVE IMMUNOGLOBULINS. Ukr Biochem J, v. 87, n. 5, p. 46-53, 2015 Sep-Oct 2015. ISSN 2409-4943. Disponível em: < https://www.ncbi.nlm.nih.gov/pubmed/26717595 >.

BOGAERT, D.; DE GROOT, R.; HERMANS, P. W. Streptococcus pneumoniae colonisation: the key to pneumococcal disease. Lancet Infect Dis, v. 4, n. 3, p. 14454, Mar 2004. ISSN 1473-3099. Disponível em: < http://www.ncbi.nlm.nih.gov/pubmed/14998500 >.

BOLANOS-GARCIA, V. M.; DAVIES, O. R. Structural analysis and classification of native proteins from $E$. coli commonly co-purified by immobilised metal affinity chromatography. Biochim Biophys Acta, v. 1760, n. 9, p. 1304-13, Sep 2006. ISSN 0006-3002. Disponível em: < https://www.ncbi.nlm.nih.gov/pubmed/16814929 >

BRANDILEONE, M. C. et al. Typing of pneumococcal surface protein A (PspA) in Streptococcus pneumoniae isolated during epidemiological surveillance in Brazil: towards novel pneumococcal protein vaccines. Vaccine, v. 22, n. 29-30, p. 3890-6, Sep 2004. ISSN 0264-410X. Disponível em: < http://www.ncbi.nlm.nih.gov/pubmed/15364436 >.

BRANDILEONE, M. C. et al. Appropriateness of a pneumococcal conjugate vaccine in Brazil: potential impact of age and clinical diagnosis, with emphasis on meningitis. $\mathbf{J}$ Infect Dis, v. 187, n. 8, p. 1206-12, Apr 2003. ISSN 0022-1899. Disponível em: < http://www.ncbi.nlm.nih.gov/pubmed/12695999 >.

BRILES, D. E. et al. The potential to use PspA and other pneumococcal proteins to elicit protection against pneumococcal infection. Vaccine, v. 18, n. 16, p. 1707-11, Feb 2000. ISSN 0264-410X. Disponível em: < http://www.ncbi.nlm.nih.gov/pubmed/10689153 >.

BRILES, D. E. et al.Immunization of humans with recombinant pneumococcal surface protein $\mathrm{A}(\mathrm{rPspA})$ elicits antibodies that passively protect mice from fatal infection with Streptococcus pneumoniae bearing heterologous PspA. J Infect Dis, v. 182, n. 6, p. 1694-701, Dec 2000. ISSN 0022-1899. Disponível em: < http://www.ncbi.nlm.nih.gov/pubmed/11069242 >.

BRILES, D. E. et al. Pneumococcal diversity: considerations for new vaccine strategies with emphasis on pneumococcal surface protein A (PspA). Clin Microbiol Rev, v. 11, n. 4, p. 645-57, Oct 1998. ISSN 0893-8512. Disponível em: < http://www.ncbi.nlm.nih.gov/pubmed/9767061 >.

BRYKSIN, A. V.; MATSUMURA, I. Overlap extension PCR cloning: a simple and reliable way to create recombinant plasmids. Biotechniques, v. 48, n. 6, p. 463-5, Jun 2010. ISSN 1940-9818. Disponível em: < http://www.ncbi.nlm.nih.gov/pubmed/20569222 >. 
CARVALHO, R. J. Produção e purificação de um fragmento recombinante da proteína A de superfície do clado 3 (PspA3) de Streptococcus pneumoniae em Escherichia coli. . 2009. (Master). Biotechnology, Universidade de São Paulo, São Paulo, SP, Brasil.

CARVALHO, R. J. et al. Development of production and purification processes of recombinant fragment of pneumococcal surface protein $A$ in Escherichia coli using different carbon sources and chromatography sequences. Appl Microbiol Biotechnol, v. 94, n. 3, p. 683-94, May 2012. ISSN 1432-0614. Disponível em: < http://www.ncbi.nlm.nih.gov/pubmed/22075630 >.

CHEN, A. et al. Multivalent Pneumococcal Protein Vaccines Comprising Pneumolysoid with Epitopes/Fragments of CbpA and/or PspA Elicit Strong and Broad Protection. Clin Vaccine Immunol, v. 22, n. 10, p. 1079-89, Oct 2015. ISSN 1556679X. Disponível em: < http://www.ncbi.nlm.nih.gov/pubmed/26245351 >.

CHEN, X.; ZARO, J. L.; SHEN, W. C. Fusion protein linkers: property, design and functionality. Adv Drug Deliv Rev, v. 65, n. 10, p. 1357-69, Oct 2013. ISSN $1872-$ 8294. Disponível em: < http://www.ncbi.nlm.nih.gov/pubmed/23026637 > .

CONSORTIUM, U. UniProt: a hub for protein information. Nucleic Acids Res, v. 43, n. Database issue, p. D204-12, Jan 2015. ISSN 1362-4962. Disponível em: < https://www.ncbi.nlm.nih.gov/pubmed/25348405 >.

DAGAN, R.; KLUGMAN, K. P. Impact of conjugate pneumococcal vaccines on antibiotic resistance. Lancet Infect Dis, v. 8, n. 12, p. 785-95, Dec 2008. ISSN 14733099. Disponível em: < https://www.ncbi.nlm.nih.gov/pubmed/19022193 >.

DANIELS, C. C.; ROGERS, P. D.; SHELTON, C. M. A Review of Pneumococcal Vaccines: Current Polysaccharide Vaccine Recommendations and Future Protein Antigens. J Pediatr Pharmacol Ther, v. 21, n. 1, p. 27-35, 2016 Jan-Feb 2016. ISSN 1551-6776. Disponível em: < https://www.ncbi.n/m.nih.gov/pubmed/26997927 >.

DARRIEUX, M. et al. Current status and perspectives on protein-based pneumococcal vaccines. Crit Rev Microbiol, Jul 2013. ISSN 1549-7828. Disponível em: < http://www.ncbi.nlm.nih.gov/pubmed/23895377 >.

DARRIEUX, M. et al. Recognition of pneumococcal isolates by antisera raised against PspA fragments from different clades. J Med Microbiol, v. 57, n. Pt 3, p. 273-8, Mar 2008. ISSN 0022-2615. Disponível em: < http://www.ncbi.nlm.nih.gov/pubmed/18287288 >.

DE LENCASTRE, $\mathrm{H}$. et al. Carriage and antibiotic resistance of respiratory pathogens and molecular epidemiology of antibiotic-resistant Streptococcus pneumoniae colonizing children in day-care centers in Lisbon: the Portuguese day-care center initiative. Clin Microbiol Infect, v. 5 Suppl 4, p. S55-S63, Aug 1999. ISSN 1469-0691. Disponível em: < http://www.ncbi.nlm.nih.gov/pubmed/11869285 >.

DE SIMONE, S. G. A arte de purificação e caracterização de proteínas. Brasil: RDS GRáfica e Editora Ltda., 2008. ISBN 978-85-89573-37-5. 
DEMAIN, A. L.; VAISHNAV, P. Production of recombinant proteins by microbes and higher organisms. Biotechnol Adv, v. 27, n. 3, p. 297-306, 2009 May-Jun 2009. ISSN 1873-1899. Disponível em: < https://www.ncbi.nlm.nih.gov/pubmed/19500547 >.

DESHMUKH, R. R. et al. Large-scale purification of antisense oligonucleotides by high-performance membrane adsorber chromatography. J Chromatogr A, v. 890, n. 1, p. 179-92, Aug 2000. ISSN 0021-9673. Disponível em: < http://www.ncbi.nlm.nih.gov/pubmed/10976805 >.

DOMMASCHK, A. et al. Nasopharyngeal colonization with Streptococcus pneumoniae triggers dendritic cell dependent antibody responses against invasive disease in mice. Eur J Immunol, v. 47, n. 3, p. 540-551, 03 2017. ISSN 1521-4141. Disponível em: < https://www.ncbi.nlm.nih.gov/pubmed/28101913 >.

DONG, H.; NILSSON, L.; KURLAND, C. G. Co-variation of tRNA abundance and codon usage in Escherichia coli at different growth rates. J Mol Biol, v. 260, n. 5, p. 649-63, Aug 1996. ISSN 0022-2836. Disponível em: < http://www.ncbi.nlm.nih.gov/pubmed/8709146 >.

DOS SANTOS, S. R. et al. Serotype distribution of Streptococcus pneumoniae isolated from patients with invasive pneumococcal disease in Brazil before and after ten-pneumococcal conjugate vaccine implementation. Vaccine, v. 31, n. 51, p. 61504, Dec 2013. ISSN 1873-2518. Disponível em: < https://www.ncbi.nlm.nih.gov/pubmed/23747454 >.

DOUCE, G. et al. Novel mucosal vaccines generated by genetic conjugation of heterologous proteins to pneumolysin (PLY) from Streptococcus pneumoniae. Vaccine, v. 28, n. 18, p. 3231-7, Apr 2010. ISSN 1873-2518. Disponível em: < http://www.ncbi.nlm.nih.gov/pubmed/20188176 >.

DUEGER, E. L. et al. Increasing penicillin and trimethoprim-sulfamethoxazole resistance in nasopharyngeal Streptococcus pneumoniae isolates from Guatemalan children, 2001--2006. Int J Infect Dis, v. 12, n. 3, p. 289-97, May 2008. ISSN 12019712. Disponível em: < http://www.ncbi.nlm.nih.gov/pubmed/18035570 >.

EHRMANN, M. Ehrmann Lab - E. coli proteases. Alemanha, 2013. Disponível em: < https://www.uni-due.de/zmb/members/ehrmann/e-coli-proteases/index.shtml $>$. Acesso em: 22 de dezembro.

EXPASY. Instability Index, ProtParam tool. 2013a. Disponível em: < https://web.expasy.org >. Acesso em: 2 de abril.

EXPASY. ProtParam Tool. 2013b. Disponível em: < http://web.expasy.org/protparam/ >. Acesso em: March, 2013.

EXPASY. ProtParam Tool. 2014. Disponível em: < http://web.expasy.org/protparam/ >. Acesso em: February, 2014.

FEIKIN, D. R. et al. Serotype-specific changes in invasive pneumococcal disease after pneumococcal conjugate vaccine introduction: a pooled analysis of multiple surveillance sites. PLoS Med, v. 10, n. 9, p. e1001517, 2013. ISSN 1549-1676. Disponível em: < https://www.ncbi.nlm.nih.gov/pubmed/24086113 >. 
FENOLL, A. et al. Evolution of Streptococcus pneumoniae serotypes and antibiotic resistance in Spain: update (1990 to 1996). J Clin Microbiol, v. 36, n. 12, p. 3447-54, Dec 1998. ISSN 0095-1137. Disponível em: < http://www.ncbi.nlm.nih.gov/pubmed/9817852 >.

FERNÁNDEZ-RESA, P.; MIRA, E.; QUESADA, A. R. Enhanced detection of casein zymography of matrix metalloproteinases. Anal Biochem, v. 224, n. 1, p. 434-5, Jan 1995. ISSN 0003-2697. Disponível em: < http://www.ncbi.nlm.nih.gov/pubmed/7710105 >.

FERREIRA, D. M. et al. Protection against nasal colonization with Streptococcus pneumoniae by parenteral immunization with a DNA vaccine encoding PspA (Pneumococcal surface protein A). Microb Pathog, v. 48, n. 6, p. 205-13, Jun 2010. ISSN 1096-1208. Disponível em: < http://www.ncbi.nlm.nih.gov/pubmed/20206678 >.

FIGUEIREDO, D. B. Desenvolvimento do processo de purificação da proteína A de superfície de pneumococo do clado 4 (PspA4pro). 2014. (Master). Instituto de Ciências Biomédicas, Universidade de São Paulo, São Paulo, Brazil.

FIGUEIREDO, D. B. et al. Production and purification of an untagged recombinant pneumococcal surface protein A (PspA4Pro) with high-purity and low endotoxin content. Appl Microbiol Biotechnol, v. 101, n. 6, p. 2305-2317, Mar 2017. ISSN 14320614. Disponível em: < https://www.ncbi.nlm.nih.gov/pubmed/27889801 >.

FINDLOW, J. et al. Multicenter, open-label, randomized phase II controlled trial of an investigational recombinant Meningococcal serogroup B vaccine with and without outer membrane vesicles, administered in infancy. Clin Infect Dis, v. 51, n. 10, p. 1127-37, Nov 2010. ISSN 1537-6591. Disponível em: < http://www.ncbi.nlm.nih.gov/pubmed/20954968 >.

FOX, B. G.; BLOMMEL, P. G. Autoinduction of protein expression. Curr Protoc Protein Sci, v. Chapter 5, p. Unit 5.23, Apr 2009. ISSN 1934-3663. Disponível em: < https://www.ncbi.nlm.nih.gov/pubmed/19365792 >.

FRAZÃO, N. et al. Effect of the seven-valent conjugate pneumococcal vaccine on carriage and drug resistance of Streptococcus pneumoniae in healthy children attending day-care centers in Lisbon. Pediatr Infect Dis J, v. 24, n. 3, p. 243-52, Mar 2005. ISSN 0891-3668. Disponível em: < http://www.ncbi.nlm.nih.gov/pubmed/15750461 >.

FREITAS-DE-SOUSA, L. A. et al. Insights into the Mechanisms Involved in Strong Hemorrhage and Dermonecrosis Induced by Atroxlysin-la, a PI-Class Snake Venom Metalloproteinase. Toxins (Basel), v. 9, n. 8, Aug 2017. ISSN 2072-6651. Disponível em: < https://www.ncbi.nlm.nih.gov/pubmed/28767072 >.

GARBETT, E. A.; REED, M. W.; BROWN, N. J. Proteolysis in human breast and colorectal cancer. Br J Cancer, v. 81, n. 2, p. 287-93, Sep 1999. ISSN 0007-0920. Disponível em: < http://www.ncbi.nlm.nih.gov/pubmed/10496354 >.

GENO, K. A. et al. Pneumococcal Capsules and Their Types: Past, Present, and Future. Clin Microbiol Rev, v. 28, n. 3, p. 871-99, Jul 2015. ISSN 1098-6618. Disponível em: < http://www.ncbi.nlm.nih.gov/pubmed/26085553 >. 
GINSBURG, A. S. et al. Issues and challenges in the development of pneumococcal protein vaccines. Expert Rev Vaccines, v. 11, n. 3, p. 279-85, Mar 2012. ISSN 17448395. Disponível em: < http://www.ncbi.nlm.nih.gov/pubmed/22380821 >.

GONÇALVES, V. M. et al. Purification of capsular polysaccharide from Streptococcus pneumoniae serotype 23F by a procedure suitable for scale-up. Biotechnol Appl Biochem, v. 37, n. Pt 3, p. 283-7, Jun 2003. ISSN 0885-4513. Disponível em: < http://www.ncbi.nlm.nih.gov/pubmed/12515577 >.

GOULART, C. et al. Characterization of protective immune responses induced by pneumococcal surface protein $A$ in fusion with pneumolysin derivatives. PLoS One, v. 8, n. 3, p. e59605, 2013. ISSN 1932-6203. Disponível em: < http://www.ncbi.nlm.nih.gov/pubmed/23533636 >.

GOULART, C. et al.Selection of family 1 PspA molecules capable of inducing broadranging cross-reactivity by complement deposition and opsonophagocytosis by murine peritoneal cells. Vaccine, v. 29, n. 8, p. 1634-42, Feb 2011. ISSN 1873-2518. Disponível em: < http://www.ncbi.nlm.nih.gov/pubmed/21211592 >.

GREENBERG, D. et al. The association between antibiotic use in the community and nasopharyngeal carriage of antibiotic-resistant Streptococcus pneumoniae in Bedouin children. Pediatr Infect Dis J, v. 27, n. 9, p. 776-82, Sep 2008. ISSN 0891-3668. Disponível em: < https://www.ncbi.nlm.nih.gov/pubmed/18645545 >.

HAMMERSCHMIDT, S. et al. Illustration of pneumococcal polysaccharide capsule during adherence and invasion of epithelial cells. Infect Immun, v. 73, n. 8, p. 465367, Aug 2005. ISSN 0019-9567. Disponível em: < http://www.ncbi.nlm.nih.gov/pubmed/16040978 >.

HANNIG, G.; MAKRIDES, S. C. Strategies for optimizing heterologous protein expression in Escherichia coli. Trends Biotechnol, v. 16, n. 2, p. 54-60, Feb 1998. ISSN 0167-7799. Disponível em: < https://www.ncbi.nlm.nih.gov/pubmed/9487731 >.

HAUSDORFF, W. P. et al. Which pneumococcal serogroups cause the most invasive disease: implications for conjugate vaccine formulation and use, part I. Clin Infect Dis, v. 30, n. 1, p. 100-21, Jan 2000. ISSN 1058-4838. Disponível em: < http://www.ncbi.nlm.nih.gov/pubmed/10619740 >.

HEINEGÅRD, D.; GARDELL, S. Studies on protein-polysaccharide complex (proteoglycan) from human nucleus pulposus. I. Isolation and preliminary characterisation. Biochim Biophys Acta, v. 148, n. 1, p. 164-71, Oct 1967. ISSN 0006-3002. Disponível em: < https://www.ncbi.nlm.nih.gov/pubmed/6077036 >.

HENRICHSEN, J. Six newly recognized types of Streptococcus pneumoniae. J Clin Microbiol, v. 33, n. 10, p. 2759-62, Oct 1995. ISSN 0095-1137. Disponível em: < http://www.ncbi.nlm.nih.gov/pubmed/8567920 >.

HIENG, B. et al. Different classes of proteases are involved in the response to drought of Phaseolus vulgaris L. cultivars differing in sensitivity. J Plant Physiol, v. 161, n. 5, 
p. 519-30, May 2004. ISSN 0176-1617. Disponível em: < https://www.ncbi.nlm.nih.gov/pubmed/15202708 >.

HIRST, R. A. et al. The role of pneumolysin in pneumococcal pneumonia and meningitis. Clin Exp Immunol, v. 138, n. 2, p. 195-201, Nov 2004. ISSN 0009-9104. Disponível em: < https://www.ncbi.nlm.nih.gov/pubmed/15498026 >.

$\mathrm{HO}, \mathrm{S} . \mathrm{N}$. et al. Site-directed mutagenesis by overlap extension using the polymerase chain reaction. Gene, v. 77, n. 1, p. 51-9, Apr 1989. ISSN 0378-1119. Disponível em: $<$ http://www.ncbi.nlm.nih.gov/pubmed/2744487 >.

HORTAL, M. et al. Antibiotic resistance in Streptococcus pneumoniae in six Latin American countries: 1993-1999 surveillance. Microb Drug Resist, v. 7, n. 4, p. 391401, 2001. ISSN 1076-6294. Disponível em: < http://www.ncbi.nlm.nih.gov/pubmed/11822779 >.

HORTON, R. M. et al. Engineering hybrid genes without the use of restriction enzymes: gene splicing by overlap extension. Gene, v. 77, n. 1, p. 61-8, Apr 1989. ISSN 0378-1119. Disponível em: < http://www.ncbi.nlm.nih.gov/pubmed/2744488 >.

HUANG, S. S. et al. Post-PCV7 changes in colonizing pneumococcal serotypes in 16 Massachusetts communities, 2001 and 2004. Pediatrics, v. 116, n. 3, p. e408-13, Sep 2005. ISSN 1098-4275. Disponível em: < http://www.ncbi.nlm.nih.gov/pubmed/16140686 >.

HUTMACHER, M. M. et al. Modeling the exposure-response relationship of etanercept in the treatment of patients with chronic moderate to severe plaque psoriasis. $\mathbf{J}$ Clin Pharmacol, v. 47, n. 2, p. 238-48, Feb 2007. ISSN 0091-2700. Disponível em: < http://www.ncbi.nlm.nih.gov/pubmed/17244775 >.

JANSON, J.-C.; RYDÉN, L. Protein Purification. 2nd. Sweden: John Wiley \& Sons, 1998. 695 ISBN 0-471-18626-0.

JEDRZEJAS, M. J.; LAMANI, E.; BECKER, R. S. Characterization of selected strains of pneumococcal surface protein A. J Biol Chem, v. 276, n. 35, p. 33121-8, Aug 2001. ISSN 0021-9258. Disponível em: < http://www.ncbi.nlm.nih.gov/pubmed/11413137 >.

JEFFERIES, J. M. et al. Presence of nonhemolytic pneumolysin in serotypes of Streptococcus pneumoniae associated with disease outbreaks. J Infect Dis, v. 196, n. 6, p. 936-44, Sep 2007. ISSN 0022-1899. Disponível em: < http://www.ncbi.nlm.nih.gov/pubmed/17703426 >.

JENA BIOSCIENCE. 2016. Disponível em: < http://www.jenabioscience.com/cms/en/1/browse/1529 histagged proteins.html >. Acesso em: 18/01/2016.

JENSEN, E. B.; CARLSEN, S. Production of recombinant human growth hormone in Escherichia coli: expression of different precursors and physiological effects of glucose, acetate, and salts. Biotechnol Bioeng, v. 36, n. 1, p. 1-11, Jun 1990. ISSN 0006-3592. Disponível em: < https://www.ncbi.nlm.nih.gov/pubmed/18592603 >. 
JIA, B.; JEON, C. O. High-throughput recombinant protein expression in Escherichia coli: current status and future perspectives. Open Biol, v. 6, n. 8, Aug 2016. ISSN 2046-2441. Disponível em: < https://www.ncbi.nlm.nih.gov/pubmed/27581654 >.

JONES, L. J. et al. Quenched BODIPY dye-labeled casein substrates for the assay of protease activity by direct fluorescence measurement. Anal Biochem, v. 251, n. 2, p. 144-52, Sep 1997. ISSN 0003-2697. Disponível em: < https://www.ncbi.nlm.nih.gov/pubmed/9299009 >.

JOSHI, B. H.; PURI, R. K. Optimization of expression and purification of two biologically active chimeric fusion proteins that consist of human interleukin-13 and Pseudomonas exotoxin in Escherichia coli. Protein Expr Purif, v. 39, n. 2, p. 189-98, Feb 2005. ISSN 1046-5928. Disponível em: < https://www.ncbi.nlm.nih.gov/pubmed/15642470 >.

KAMTCHOUA, T. et al. Safety and immunogenicity of the pneumococcal pneumolysin derivative PlyD1 in a single-antigen protein vaccine candidate in adults. Vaccine, v. 31, n. 2, p. 327-33, Jan 2013. ISSN 1873-2518. Disponível em: < http://www.ncbi.nlm.nih.gov/pubmed/23153437 >.

KARMALI, A. Cromatografia de afinidade com metal imobilizado e suas variantes. Boletim de Biotecnologia. Potugal: Sociedade Portuguesa de Biotecnologia. 672000.

KAUSHIK, J. K.; BHAT, R. Why is trehalose an exceptional protein stabilizer? An analysis of the thermal stability of proteins in the presence of the compatible osmolyte trehalose. J Biol Chem, v. 278, n. 29, p. 26458-65, Jul 2003. ISSN 0021-9258. Disponível em: < https://www.ncbi.nlm.nih.gov/pubmed/12702728 >.

KNITTEL, P. S. et al. Characterising the enzymatic profile of crude tentacle extracts from the South Atlantic jellyfish Olindias sambaquiensis (Cnidaria: Hydrozoa). Toxicon, v. 119, p. 1-7, Sep 2016. ISSN 1879-3150. Disponível em: < https://www.ncbi.nlm.nih.gov/pubmed/27169682 >.

KNUDSEN, H. L. et al. Membrane ion-exchange chromatography for process-scale antibody purification. J Chromatogr A, v. 907, n. 1-2, p. 145-54, Jan 2001. ISSN 00219673. Disponível em: < https://www.ncbi.nlm.nih.gov/pubmed/11217020 > .

KOTIK, M. et al. High-level expression of a fungal pyranose oxidase in high celldensity fed-batch cultivations of Escherichia coli using lactose as inducer. Protein Expr Purif, v. 36, n. 1, p. 61-9, Jul 2004. ISSN 1046-5928. Disponível em: < https://www.ncbi.nlm.nih.gov/pubmed/15177285 >.

LAIMER, J. et al. MAESTROweb: a web server for structure-based protein stability prediction. Bioinformatics, v. 32, n. 9, p. 1414-6, May 2016. ISSN 1367-4811. Disponível em: < https://www.ncbi.nlm.nih.gov/pubmed/26743508 >.

LANDER, R. J. et al. Fractional precipitation of plasmid DNA from lysate by CTAB. Biotechnol Bioeng, v. 79, n. 7, p. 776-84, Sep 2002. ISSN 0006-3592. Disponível em: $<$ https://www.ncbi.nlm.nih.gov/pubmed/12209800 > .

LEBER, T. M.; BALKWILL, F. R. Zymography: a single-step staining method for quantitation of proteolytic activity on substrate gels. Anal Biochem, v. 249, n. 1, p. 24- 
8, Jun 1997. ISSN 0003-2697. Disponível em: < http://www.ncbi.nlm.nih.gov/pubmed/9193704 >.

LEE, C. W.; GU, M. B.; CHANG, H. N. High-density culture of Escherichia coli carrying recombinant plasmid in a membrane cell recyde fermenter. Enzyme Microbiology Technology, v. 11, n. 1, p. 6, 1989. Disponível em: < http://www.sciencedirect.com.https.sci-hub.tv/science/article/pii/0141022989901130 $>$.

LEE, J. et al. Secretory production of Arthrobacter levan fructotransferase from recombinant Escherichia coli. FEMS Microbiol Lett, v. 195, n. 2, p. 127-32, Feb 2001. ISSN 0378-1097. Disponível em: < http://www.ncbi.nlm.nih.gov/pubmed/11179640 >.

LEE, M. et al. Enhanced antibacterial activity of an attacin-coleoptericin hybrid protein fused with a helical linker. Mol Biol Rep, v. 40, n. 6, p. 3953-60, Jun 2013. ISSN 15734978. Disponível em: < http://www.ncbi.nlm.nih.gov/pubmed/23271135 >.

LEROUX-ROELS, G. et al. Safety, reactogenicity and immunogenicity of a novel pneumococcal protein-based vaccine in adults: a phase I/II randomized clinical study. Vaccine, v. 32, n. 50, p. 6838-46, Nov 2014. ISSN 1873-2518. Disponível em: < http://www.ncbi.nlm.nih.gov/pubmed/24607003 >.

$\mathrm{LIAO}, \mathrm{Y} . \mathrm{H}$. et al. Protective mechanism of stabilizing excipients against dehydration in the freeze-drying of proteins. Pharm Res, v. 19, n. 12, p. 1854-61, Dec 2002. ISSN 0724-8741. Disponível em: < https://www.ncbi.nlm.nih.gov/pubmed/12523665 >.

LITTMANN, M. et al. Streptococcus pneumoniae evades human dendritic cell surveillance by pneumolysin expression. EMBO Mol Med, v. 1, n. 4, p. 211-22, Jul 2009. ISSN 1757-4684. Disponível em: < http://www.ncbi.nlm.nih.gov/pubmed/20049723 >.

LIXANDRU, R. I. et al. Streptococcus pneumoniae Serotypes and Antibiotic Susceptibility Patterns in Middle Ear Fluid Isolates During Acute Otitis Media and Nasopharyngeal Isolates During Community-acquired Alveolar Pneumonia in Central Romania. Pediatr Infect Dis J, v. 36, n. 2, p. 151-154, Feb 2017. ISSN 1532-0987. Disponível em: < https://www.ncbi.nlm.nih.gov/pubmed/27798547 >.

LIÑARES, J. et al. Changes in antimicrobial resistance, serotypes and genotypes in Streptococcus pneumoniae over a 30-year period. Clin Microbiol Infect, v. 16, n. 5, p. 402-10, May 2010. ISSN 1469-0691. Disponível em: < http://www.ncbi.nlm.nih.gov/pubmed/20132251 >.

LU, Y. J. et al. Protection against Pneumococcal colonization and fatal pneumonia by a trivalent conjugate of a fusion protein with the cell wall polysaccharide. Infect Immun, v. 77, n. 5, p. 2076-83, May 2009. ISSN 1098-5522. Disponível em: < http://www.ncbi.nlm.nih.gov/pubmed/19255193 >.

MADIGAN, M. T. et al. Microbiologia de Brock. 12. Artmed, 2010.

MAKRIDES, S. C. Strategies for achieving high-level expression of genes in Escherichia coli. Microbiol Rev, v. 60, n. 3, p. 512-38, Sep 1996. ISSN 0146-0749. Disponível em: < http://www.ncbi.nlm.nih.gov/pubmed/8840785 >. 
MALLEY, R. et al. Recognition of pneumolysin by Toll-like receptor 4 confers resistance to pneumococcal infection. Proc Natl Acad Sci U S A, v. 100, n. 4, p. 196671, Feb 2003. ISSN 0027-8424. Disponível em: < http://www.ncbi.nlm.nih.gov/pubmed/12569171 >.

MANCUSO, R. I. et al. Impaired expression of CXCL5 and matrix metalloproteinases in the lungs of mice with high susceptibility to Streptococcus pneumoniae infection. Immun Inflamm Dis, Nov 2017. ISSN 2050-4527. Disponível em: < https://www.ncbi.nlm.nih.gov/pubmed/29119707 >.

MANGTANI, P.; CUTTS, F.; HALL, A. J. Efficacy of polysaccharide pneumococcal vaccine in adults in more developed countries: the state of the evidence. Lancet Infect Dis, v. 3, n. 2, p. 71-8, Feb 2003. ISSN 1473-3099. Disponível em: < http://www.ncbi.nlm.nih.gov/pubmed/12560191 >.

MANN, B. et al. Broadly protective protein-based pneumococcal vaccine composed of pneumolysin toxoid-CbpA peptide recombinant fusion protein. J Infect Dis, v. 209, n. 7, p. 1116-25, Apr 2014. ISSN 1537-6613. Disponível em: < http://www.ncbi.nlm.nih.gov/pubmed/24041791 >.

MARRIE, T. J. et al. Invasive Pneumococcal Disease: Still Lots to Learn and a Need for Standardized Data Collection Instruments. Can Respir J, v. 2017, p. 2397429, 2017. ISSN 1916-7245. Disponível em: < https://www.ncbi.nlm.nih.gov/pubmed/28424565 >.

MAURIZI, M. R. Proteases and protein degradation in Escherichia coli. Experientia, v. 48, n. 2, p. 178-201, Feb 1992. ISSN 0014-4754. Disponível em: < https://www.ncbi.nlm.nih.gov/pubmed/1740190 >.

MAX PLANCK INSTITUTE FOR POLYMER RESEARCH. Gel Permeation Chromatography (GPC) Size Exclusion Chromatography (SEC). 2003-2016. Disponível em: < <span style="font-size:10.0pt >.Disponível em: < mso-bidi-fontweight:bold"> http://www.mpip-mainz.mpg.de/3250477/GPC<span lang="X-NONE" style="font-size:8.0pt >. Acesso em: 25/02/2016.

MCNEELA, E. A. et al. Pneumolysin activates the NLRP3 inflammasome and promotes proinflammatory cytokines independently of TLR4. PLoS Pathog, v. 6, n. 11, p. e1001191, 2010. ISSN 1553-7374. Disponível em: < http://www.ncbi.nlm.nih.gov/pubmed/21085613 >.

MEDEIROS, M. I. C. et al. Distribution of Streptococcus pneumoniae serotypes in the northeast macro-region of São Paulo state/Brazil after the introduction of conjugate vaccine. BMC Infect Dis, v. 17, n. 1, p. 590, Aug 2017. ISSN 1471-2334. Disponível em: < https://www.ncbi.nlm.nih.gov/pubmed/28841854 >.

MITCHELL, T. J. et al. Expression of the pneumolysin gene in Escherichia coli: rapid purification and biological properties. Biochim Biophys Acta, v. 1007, n. 1, p. 67-72, Jan 1989. ISSN 0006-3002. Disponível em: < http://www.ncbi.nlm.nih.gov/pubmed/2642385 >. 
MIYAJI, E. N. et al. Serotype-independent pneumococcal vaccines. Cell Mol Life Sci, v. 70 , n. 18, p. 3303-26, Sep 2013. ISSN 1420-9071. Disponível em: < http://www.ncbi.nlm.nih.gov/pubmed/23269437 >.

MORENO, A. T. et al. Immunization of mice with single PspA fragments induces antibodies capable of mediating complement deposition on different pneumococcal strains and cross-protection. Clin Vaccine Immunol, v. 17, n. 3, p. 439-46, Mar 2010. ISSN 1556-679X. Disponível em: < http://www.ncbi.nlm.nih.gov/pubmed/20089795 >.

MURBY, M.; UHLÉN, M.; STÅHL, S. Upstream strategies to minimize proteolytic degradation upon recombinant production in Escherichia coli. Protein Expr Purif, v. 7, n. 2, p. 129-36, Mar 1996. ISSN 1046-5928. Disponível em: < https://www.ncbi.nlm.nih.gov/pubmed/8812844 >.

NABORS, G. S. et al. Immunization of healthy adults with a single recombinant pneumococcal surface protein A (PspA) variant stimulates broadly cross-reactive antibodies to heterologous PspA molecules. Vaccine, v. 18, n. 17, p. 1743-54, Mar 2000. ISSN 0264-410X. Disponível em: < http://www.ncbi.nlm.nih.gov/pubmed/10699322 >.

NEUBAUER, $P$. et al. Maximizing the expression of a recombinant gene in Escherichia coli by manipulation of induction time using lactose as inducer. Appl Microbiol Biotechnol, v. 36, n. 6, p. 739-44, Mar 1992. ISSN 0175-7598. Disponível em: < http://www.ncbi.nlm.nih.gov/pubmed/1369364 >.

NEW ENGLAND BIOLABS. Online Tm calculator. 2014. Disponível em: < https://www.neb.com/tools-and-resources/interactive-tools/tm-calculator $>$. Acesso em: April 2014.

NEW ENGLISH BIOLABS. PCR Troubleshooting Guide. 2015. Disponível em: < https://www.neb.com/tools-and-resources/troubleshooting-guides/pcr-

troubleshooting-guide $>$. Acesso em: 04/05/2015.

NOVAGEN. pET-28a-c(+) Vectors: Novagen 1998.

NOVAGEN.pET System Manual: Novagen 1999.

O'BRIEN, K. L. et al. Burden of disease caused by Streptococcus pneumoniae in children younger than 5 years: global estimates. Lancet, v. 374, n. 9693, p. 893-902, Sep 2009. ISSN 1474-547X. Disponível em: < https://www.ncbi.nlm.nih.gov/pubmed/19748398 >.

$\mathrm{OCHOA}, \mathrm{T}$. J. et al. Penicillin resistance and serotypes/serogroups of Streptococcus pneumoniae in nasopharyngeal carrier children younger than 2 years in Lima, Peru. Diagn Microbiol Infect Dis, v. 52, n. 1, p. 59-64, May 2005. ISSN 0732-8893. Disponível em: < http://www.ncbi.nlm.nih.gov/pubmed/15878444 >.

OHTAKE, S.; WANG, Y. J. Trehalose: current use and future applications. J Pharm Sci, v. 100, n. 6, p. 2020-53, Jun 2011. ISSN 1520-6017. Disponível em: < http://www.ncbi.nlm.nih.gov/pubmed/21337544 >. 
ORGANIZACIÓN PANAMERICANA DE LA SALUD. Informe Regional de SIREVA II, 2012. Datos por país y por grupos de edad sobre las características de los aislamientos de Streptococcus pneumoniae, Haemophilus influenzae y Neisseria meningitidis, en procesos invasores. Washington DC: www.paho.org 2013.

ORTQVIST, A.; HEDLUND, J.; KALIN, M. Streptococcus pneumoniae: epidemiology, risk factors, and clinical features. Semin Respir Crit Care Med, v. 26, n. 6, p. 563-74, Dec 2005. ISSN 1069-3424. Disponível em: < https://www.ncbi.nlm.nih.gov/pubmed/16388428 >.

PADALA, C. et al. Impact of Uncontrolled vs Controlled Rate Freeze-Thaw Technologies on Process Performance and Product Quality. PDA J Pharm Sci Technol, v. 64, n. 4, p. 290-8, 2010 Jul-Aug 2010. ISSN 1948-2124. Disponível em: < https://www.ncbi.nlm.nih.gov/pubmed/21502029 >.

PANATTO, D. et al. Neisseria meningitidis B vaccines. Expert Rev Vaccines, v. 10, n. 9, p. 1337-51, Sep 2011. ISSN 1744-8395. Disponível em: < http://www.ncbi.nlm.nih.gov/pubmed/21919622 >.

PANDURANGAN, A. P. et al. SDM: a server for predicting effects of mutations on protein stability. Nucleic Acids Res, May 2017. ISSN 1362-4962. Disponível em: < https://www.ncbi.nlm.nih.gov/pubmed/28525590 >.

PATON, J. C.; FERRANTE, A. Inhibition of human polymorphonuclear leukocyte respiratory burst, bactericidal activity, and migration by pneumolysin. Infect Immun, v. 41 , n. 3, p. 1212-6, Sep 1983. ISSN 0019-9567. Disponível em: < https://www.ncbi.nlm.nih.gov/pubmed/6885160 >.

PIRES, D. E.; ASCHER, D. B.; BLUNDELL, T. L. DUET: a server for predicting effects of mutations on protein stability using an integrated computational approach. Nucleic Acids Res, v. 42, n. Web Server issue, p. W314-9, Jul 2014. ISSN 1362-4962. Disponível em: < https://www.ncbi.nlm.nih.gov/pubmed/24829462 >.

POOLMAN, J. T.; PEETERS, C. C.; VAN DEN DOBBELSTEEN, G. P. The history of pneumococcal conjugate vaccine development: dose selection. Expert Rev Vaccines, v. 12, n. 12, p. 1379-94, Dec 2013. ISSN 1744-8395. Disponível em: < https://www.ncbi.nlm.nih.gov/pubmed/24195479 >.

PORATH, J. Immobilized metal ion affinity chromatography. Protein Expr Purif, v. 3, n. 4, p. 263-81, Aug 1992. ISSN 1046-5928. Disponível em: < http://www.ncbi.nlm.nih.gov/pubmed/1422221 >.

PROMEGA. Technical Manual pGEM-T and pGEM-T Easy Vector System: Promega: 9 p. 2010.

PROTEIN CALCULATOR. Protein Calculator v. 3.4. 2013. Disponível em: < http://protcalc. sourceforge.net/ >. Acesso em: March, 2013.

PRYMULA, R. et al. Safety and immunogenicity of an investigational vaccine containing two common pneumococcal proteins in toddlers: a phase II randomized clinical trial. Vaccine, v. 32, n. 25, p. 3025-34, May 2014. ISSN 1873-2518. Disponível em: < http://www.ncbi.nlm.nih.gov/pubmed/24699466 >. 
RAWLINGS, N. D. et al. MEROPS: the database of proteolytic enzymes, their substrates and inhibitors. Nucleic Acids Res, v. 42, n. Database issue, p. D503-9, Jan 2014. ISSN 1362-4962. Disponível em: < https://www.ncbi.nlm.nih.gov/pubmed/24157837 >.

REDDY CHICHILI, V. P.; KUMAR, V.; SIVARAMAN, J. Linkers in the structural biology of protein-protein interactions. Protein Sci, v. 22, n. 2, p. 153-67, Feb 2013. ISSN 1469-896X. Disponível em: < http://www.ncbi.nlm.nih.gov/pubmed/23225024 >.

REIKOFSKI, J.; TAO, B. Y. Polymerase chain reaction (PCR) techniques for sitedirected mutagenesis. Biotechnol Adv, v. 10, n. 4, p. 535-47, 1992. ISSN 0734-9750. Disponível em: < http://www.ncbi.nlm.nih.gov/pubmed/14543704 >.

REIMERDES, E. H.; KLOSTERMEYER, H. Determination of proteolytic activities on casein substrates. Methods Enzymol, v. 45, p. 26-8, 1976. ISSN 0076-6879. Disponível em: < https://www.ncbi.nlm.nih.gov/pubmed/13263 >.

ROBBINS, J. W.; TAYLOR, K. B. Optimization of Escherichia coli growth by controlled addition of glucose. Biotechnol Bioeng, v. 34, n. 10, p. 1289-94, Dec 1989. ISSN 0006-3592. Disponível em: < http://www.ncbi.nlm.nih.gov/pubmed/18588069 >.

ROSANO, G. L.; CECCARELLI, E. A. Recombinant protein expression in Escherichia coli: advances and challenges. Front Microbiol, v. 5, p. 172, 2014. ISSN 1664-302X. Disponível em: < http://www.ncbi.nlm.nih.gov/pubmed/24860555 >.

ROSSJOHN, J. et al. The molecular mechanism of pneumolysin, a virulence factor from Streptococcus pneumoniae. J Mol Biol, v. 284, n. 2, p. 449-61, Nov 1998. ISSN 0022-2836. Disponível em: < http://www.ncbi.nlm.nih.gov/pubmed/9813129 >.

SADARANGANI, M.; POLLARD, A. J. Serogroup B meningococcal vaccines-an unfinished story. Lancet Infect Dis, v. 10, n. 2, p. 112-24, Feb 2010. ISSN 1474-4457. Disponível em: < http://www.ncbi.nlm.nih.gov/pubmed/20113980 >.

SALHA, D. et al. Neutralizing antibodies elicited by a novel detoxified pneumolysin derivative, PlyD1, provide protection against both pneumococcal infection and lung injury. Infect Immun, v. 80, n. 6, p. 2212-20, Jun 2012. ISSN 1098-5522. Disponível em: < https://www.ncbi.nlm.nih.gov/pubmed/22473606 >.

SANTOLAYA, M. E. et al. Immunogenicity and tolerability of a multicomponent meningococcal serogroup $B(4 \mathrm{CMenB})$ vaccine in healthy adolescents in Chile: a phase $2 \mathrm{~b} / 3$ randomised, observer-blind, placebo-controlled study. Lancet, v. 379 , $\mathrm{n}$. 9816, p. 617-24, Feb 2012. ISSN 1474-547X. Disponível em: < http://www.ncbi.nlm.nih.gov/pubmed/22260988 >.

SARASWAT, M. et al. Preparative purification of recombinant proteins: current status and future trends. Biomed Res Int, v. 2013, p. 312709, 2013. ISSN 2314-6141. Disponível em: < https://www.ncbi.nlm.nih.gov/pubmed/24455685 >.

SARTORIUS STEDIM. Sartobind Q. 2017. Disponível em: < https://www.sartorius.com/sartorius/en/EUR/BioProcess/Process-Solutions/mABBioProcess/Downstream-Processing/Polishing/Sartobind® $\mathrm{B}-\mathrm{Q} / \mathrm{p} / \mathrm{M}$ _Sartobind_Q $>$. Acesso em: 18 de dezembro de 2017. 
SATO, J. C. M. D. C. S. Fermentação Descontínua Alimentada. In: (Ed.). Biotecnologia Industrial. 2. Brasil: Edgard Blücher, v.2, 2001. cap. 10, p.205-218.

SCHMIDEDER, A.; WEUSTER-BOTZ, D. High-performance recombinant protein production with Escherichia coli in continuously operated cascades of stirred-tank reactors. J Ind Microbiol Biotechnol, v. 44, n. 7, p. 1021-1029, Jul 2017. ISSN 14765535. Disponível em: < https://www.ncbi.nlm.nih.gov/pubmed/28251388 >.

SEEGER, A. et al. Comparison of temperature- and isopropyl- $\beta$ - $d$-thiogalactopyranoside-induced synthesis of basic fibroblast growth factor in high-cell-density cultures of recombinant Escherichia coli. Enzyme and Microbial Technology, v. 17, n. 10, p. 7, 1995. ISSN 10. Disponível em: < http://www.sciencedirect.com/science/article/pii/0141022994001239 >.

SENKOVICH, O. et al. Structure of a complex of human lactoferrin N-lobe with pneumococcal surface protein a provides insight into microbial defense mechanism. $\mathbf{J}$ Mol Biol, v. 370, n. 4, p. 701-13, Jul 2007. ISSN 0022-2836. Disponível em: < http://www.ncbi.nlm.nih.gov/pubmed/17543335 >.

SHAPER, M. et al. PspA protects Streptococcus pneumoniae from killing by apolactoferrin, and antibody to PspA enhances killing of pneumococci by apolactoferrin [corrected]. Infect Immun, v. 72, n. 9, p. 5031-40, Sep 2004. ISSN 0019-9567. Disponível em: < http://www.ncbi.nlm.nih.gov/pubmed/15321996 >.

SHULER, M. L.; KARG, F. Bioprocess engineering : basic concepts. Englewood Cliffs, N.J.: Prentice Hall, 1992. xvi, 479 p.

SINGH, L. R. et al. Protein and DNA destabilization by osmolytes: the other side of the coin. Life Sci, v. 88, n. 3-4, p. 117-25, Jan 2011. ISSN 1879-0631. Disponível em: $<$ http://www.ncbi.nlm.nih.gov/pubmed/21047521 >.

SONG, J. et al. PROSPER: an integrated feature-based tool for predicting protease substrate cleavage sites. PLoS One, v. 7, n. 11, p. e50300, 2012. ISSN 1932-6203. Disponível em: < https://www.ncbi.nlm.nih.gov/pubmed/23209700 >.

SONG, J. H. et al. The relationship between pneumococcal serotypes and antibiotic resistance. Vaccine, v. 30, n. 17, p. 2728-37, Apr 2012. ISSN 1873-2518. Disponível em: < https://www.ncbi.nlm.nih.gov/pubmed/22330126 >.

SPIEGEL, $H$. et al. Optimization of a multi-stage, multi-subunit malaria vaccine candidate for the production in Pichia pastoris by the identification and removal of protease cleavage sites. Biotechnol Bioeng, v. 112, n. 4, p. 659-67, Apr 2015. ISSN 1097-0290. Disponível em: < http://www.ncbi.nlm.nih.gov/pubmed/25335451 >.

SRIVASTAVA, A. et al. The apoptotic response to pneumolysin is Toll-like receptor 4 dependent and protects against pneumococcal disease. Infect Immun, v. 73, n. 10, p. 6479-87, Oct 2005. ISSN 0019-9567. Disponível em: < https://www.ncbi.nlm.nih.gov/pubmed/16177320 >. 
STRICKLEY, R. G. Solubilizing excipients in oral and injectable formulations. Pharm Res, v. 21, n. 2, p. 201-30, Feb 2004. ISSN 0724-8741. Disponível em: < https://www.ncbi.nlm.nih.gov/pubmed/15032302 >.

\section{SUBSTECH. Homogeneizador de alta pressão 2005.}

SØRENSEN, H. P.; MORTENSEN, K. K. Soluble expression of recombinant proteins in the cytoplasm of Escherichia coli. Microb Cell Fact, v. 4, n. 1, p. 1, Jan 2005. ISSN 1475-2859. Disponível em: < https://www.ncbi.nlm.nih.gov/pubmed/15629064 >.

TAYLOR, S. D. et al. The cholesterol-dependent cytolysin pneumolysin from Streptococcus pneumoniae binds to lipid raft microdomains in human corneal epithelial cells. PLoS One, v. 8, n. 4, p. e61300, 2013. ISSN 1932-6203. Disponível em: < http://www.ncbi.nlm.nih.gov/pubmed/23577214 >.

TEGEL, $\mathrm{H}$. et al. Increased levels of recombinant human proteins with the Escherichia coli strain Rosetta(DE3). Protein Expr Purif, v. 69, n. 2, p. 159-67, Feb 2010. ISSN 1096-0279. Disponível em: < https://www.ncbi.nlm.nih.gov/pubmed/19733669 >.

TERPE, K. Overview of bacterial expression systems for heterologous protein production: from molecular and biochemical fundamentals to commercial systems. Appl Microbiol Biotechnol, v. 72, n. 2, p. 211-22, Sep 2006. ISSN 0175-7598. Disponível em: < https://www.ncbi.nlm.nih.gov/pubmed/16791589 >.

TOMANEE, P.; HSU, J. T.; ITO, Y. Fractionation of protein, RNA, and plasmid DNA in centrifugal precipitation chromatography using cationic surfactant CTAB containing inorganic salts $\mathrm{NaCl}$ and $\mathrm{NH}(4) \mathrm{Cl}$. Biotechnol Bioeng, v. 88, n. 1, p. 52-9, Oct 2004. ISSN 0006-3592. Disponível em: < http://www.ncbi.nlm.nih.gov/pubmed/15384057 >.

VACCINES EUROPE. How are vaccines produced? , 2017. Disponível em: < https://www.vaccineseurope.eu/about-vaccines/key-facts-on-vaccines/how-arevaccines-produced/ > . Acesso em: 2 de dezembro de 2017.

VAN DER POLL, T.; OPAL, S. M. Pathogenesis, treatment, and prevention of pneumococcal pneumonia. Lancet, v. 374, n. 9700, p. 1543-56, Oct 2009. ISSN 1474547X. Disponível em: < https://www.ncbi.nlm.nih.gov/pubmed/19880020 >.

VAN DYKE, M. K. et al. Etiology of Acute Otitis Media in Children Less Than 5 Years of Age: A Pooled Analysis of 10 Similarly Designed Observational Studies. Pediatr Infect Dis J, v. 36, n. 3, p. 274-281, Mar 2017. ISSN 1532-0987. Disponível em: < https://www.ncbi.nlm.nih.gov/pubmed/27918383 >.

VAN METRE, T. E. et al. Pain and dermal reaction caused by injected glycerin in immunotherapy solutions. J Allergy Clin Immunol, v. 97, n. 5, p. 1033-9, May 1996. ISSN 0091-6749. Disponível em: < https://www.ncbi.nlm.nih.gov/pubmed/8626978 >.

VANDOOREN, J. et al. Zymography methods for visualizing hydrolytic enzymes. Nat Methods, v. 10, n. 3, p. 211-20, Mar 2013. ISSN 1548-7105. Disponível em: < http://www.ncbi.nlm.nih.gov/pubmed/23443633 >.

VELA CORAL, M. C. et al. Pneumococcal surface protein A of invasive Streptococcus pneumoniae isolates from Colombian children. Emerg Infect Dis, v. 7, n. 5, p. 832-6, 
2001 Sep-Oct 2001. ISSN 1080-6040. Disponível em: < http://www.ncbi.nlm.nih.gov/pubmed/11747695 >.

VIEIRA, A. C. et al. Streptococcus pneumoniae: a study of strains isolated from cerebrospinal fluid. J Pediatr (Rio J), v. 83, n. 1, p. 71-8, 2007 Jan-Feb 2007. ISSN 0021-7557. Disponível em: < http://www.ncbi.nlm.nih.gov/pubmed/17279283 >.

WANG, W. Oral protein drug delivery. J Drug Target, v. 4, n. 4, p. 195-232, 1996. ISSN 1061-186X. Disponível em: < https://www.ncbi.nlm.nih.gov/pubmed/9010812 >.

WANG, W. Instability, stabilization, and formulation of liquid protein pharmaceuticals. Int J Pharm, v. 185, n. 2, p. 129-88, Aug 1999. ISSN 0378-5173. Disponível em: < http://www.ncbi.nlm.nih.gov/pubmed/10460913 >.

WEINBERGER, D. M.; MALLEY, R.; LIPSITCH, M. Serotype replacement in disease after pneumococcal vaccination. Lancet, v. 378, n. 9807, p. 1962-73, Dec 2011. ISSN 1474-547X. Disponível em: < https://www.ncbi.nlm.nih.gov/pubmed/21492929 >.

WEINBERGER, D. M. et al. Pneumococcal capsular polysaccharide structure predicts serotype prevalence. PLoS Pathog, v. 5, n. 6, p. e1000476, Jun 2009. ISSN 15537374. Disponível em: < https://www.ncbi.nlm.nih.gov/pubmed/19521509 >.

WHEELWRIGHT, S. M. Protein Purification: Desing and Scale Up of Downstream Processing. Hanser PublishersHanser Publishers, 1991.

WITZENRATH, M. et al. The NLRP3 inflammasome is differentially activated by pneumolysin variants and contributes to host defense in pneumococcal pneumonia. $\mathbf{J}$ Immunol, v. 187, n. 1, p. 434-40, Jul 2011. ISSN 1550-6606. Disponível em: < https://www.ncbi.nlm.nih.gov/pubmed/21646297 >.

WOLF , G. A.; WIRTH , S. J. Soluble, dye-labelled substrates for a micro-plate assay of proteinase activity. Journal of Microbiological Methods, v. 25, n. 3, p. 6, 1996. Disponível em: https://www.sciencedirect.com/science/article/pii/016770129600005X >.

WORLD HEALTH ORGANIZATION. WHO position paper on pneumococcal vaccines 2012.

XIE, M.; SCHOWEN, R. L. Secondary structure and protein deamidation. J Pharm Sci, v. 88, n. 1, p. 8-13, Jan 1999. ISSN 0022-3549. Disponível em: < https://www.ncbi.nlm.nih.gov/pubmed/9874696 >.

YEE, L.; BLANCH, H. W. Recombinant protein expression in high cell density fed-batch cultures of Escherichia coli. Biotechnology (N Y), v. 10, n. 12, p. 1550-6, Dec 1992. ISSN 0733-222X. Disponível em: < https://www.ncbi.nlm.nih.gov/pubmed/1369204 >.

YOTHER, J. et al. Generation and properties of a Streptococcus pneumoniae mutant which does not require choline or analogs for growth. J Bacteriol, v. 180, n. 8, p. 2093101, Apr 1998. ISSN 0021-9193. Disponível em: < http://www.ncbi.nlm.nih.gov/pubmed/9555891 >. 
ZAFAR, M. A. et al. Host-to-Host Transmission of Streptococcus pneumoniae Is Driven by Its Inflammatory Toxin, Pneumolysin. Cell Host Microbe, v. 21, n. 1, p. 7383, Jan 2017. ISSN 1934-6069. Disponível em: < https://www.ncbi.nlm.nih.gov/pubmed/28081446 >.

ZAHA, A.; FERREIRA, H. B.; PASSAGLIA, L. M. P. Biologia molecular básica. 2. Mercado Aberto, 2003.

ZHANG, J.; GREASHAM, R. Chemically defined media for commercial fermentations. Applied Microbiology and Biotechnology, v. 51, n. 4, 1998. ISSN 1432-0614.

ZHAO, H. L. et al. Increasing the homogeneity, stability and activity of human serum albumin and interferon-alpha2b fusion protein by linker engineering. Protein Expr Purif, v. 61, n. 1, p. 73-7, Sep 2008. ISSN 1096-0279. Disponível em: < http://www.ncbi.nlm.nih.gov/pubmed/18541441 >.

ZHOU, A. et al. Structural mechanism for the carriage and release of thyroxine in the blood. Proc Natl Acad Sci U S A, v. 103, n. 36, p. 13321-6, Sep 2006. ISSN 00278424. Disponível em: < https://www.ncbi.nlm.nih.gov/pubmed/16938877 >. 


\section{APÊNDICE A - PspA94-PdT sem espaçador}

Esta construção possui 839 aminoácidos, seu pl teórico é 5,4 (Protein Calculator, 2013) e sua massa molecular é de $94382.7 \mathrm{~g} / \mathrm{mol}$ (Expasy, 2013b).

Tabela I A - Sequência de aminoácidos da PspA94-PdT sem espaçador. Em amarelo: aminoácidos provenientes do vetor de expressão pQE-30; em verde: PspA94; em vermelho: sítio de restrição da enzima Xbal;em marrom: sítio de restrição da enzima Xhol, em azul: PdT e em rosa: porção da PspA retirada das demais construções.

\section{PspA94-PdT sem espaçador}

M R G SHHHHHGSACELEAPVASQSKAEKDYDA A VKKYKAAEED LKKAEAAQRKYDEDQKKTEEKAKETEEASKRQQAANLKYQLKL REYLKYIQEKNKEKIAKAEKEMNEAKQEEDKEK ANLNKVLAKVI PSDRELEKTRQEAEKAKKNIPELKKKVEEAKQKVDAAKQKVDA EHAKEVAPQAKIAELENQVHRLEQDLKDINESDSEDYVKEGLRA PLQSELDTKKAKLLKLEELSGKIEELDAEIAELEVQLKDAEGN N NVEAYFKEGLEKTTAEKKAELEKAEADLKKAVDEPETPAPAPAP AP APE APAP AP AP APQP AP APKPEKTDDQQAEEDY ARRSEEEY NRLPQQQLPKAESRLEM ANKAVNDFILAMNYDKKKLLTHQGESI ENRFIKE GN Q L P E F V VIERKKRSLSTNTSDISVTATNDSRLYPG A L L V V DETLLENNPTLLAVDRAPMTYSIDLPGLASSDSFLQVED PSNSSVRGAVNDLLAKWHQDYGQVNNVPARMQYEKITAHSMEQ LKVKFGSDFEKTGNSLDIDFNSVHSGEKQIQIVNFKQIYYTVSVD A VKNPGDVFQDTVTVEDLKQRGISAERPLVYISSVAYGRQVYLK LETTSKSDEVEAAFEALIKGVKV APQTEWKQILDNTEVKAVILGG DPSSGARVVTGKVDMVEDLIQEGSRFT ADHPGLPISYTTSFLRD NVVATFQNSTDYVETKVTAYRNGDLLLDHSGAYVAQYYITWDEL S Y N HQGKE VLTPKAWDRNGQDLTAHFT T I PLKGN VR L S VKIR EGTGLAFEW WRTVYEKTDLPLVRKRTISIWGTTLYPQVEDKVEN D Stop 
Tabela I B - Composição em porcentagem de aminoácidos da PspA94-PdT sem espaçador.

\begin{tabular}{|c|c|c|}
\hline Aminoácido & Quantidade absoluta & Porcentagem \\
\hline Ala $(A)$ & 85 & $10,1 \%$ \\
\hline $\operatorname{Arg}(\mathrm{R})$ & 32 & $3,8 \%$ \\
\hline Asn $(\mathrm{N})$ & 38 & $4,5 \%$ \\
\hline Asp (D) & 56 & $6,7 \%$ \\
\hline Cys $(C)$ & 1 & $0,1 \%$ \\
\hline $\mathrm{Gln}(\mathrm{Q})$ & 43 & $5,1 \%$ \\
\hline Glu (E) & 93 & $11,1 \%$ \\
\hline Gly (G) & 33 & $3,9 \%$ \\
\hline His $(\mathrm{H})$ & 16 & $1,9 \%$ \\
\hline Ile (I) & 31 & $3,7 \%$ \\
\hline Leu (L) & 70 & $8,3 \%$ \\
\hline Lys (K) & 88 & $10,5 \%$ \\
\hline Met (M) & 8 & $1,0 \%$ \\
\hline Phe (F) & 16 & $1,9 \%$ \\
\hline Pro $(P)$ & 41 & $4,9 \%$ \\
\hline Ser (S) & 48 & $5,7 \%$ \\
\hline Thr $(\mathrm{T})$ & 45 & $5,4 \%$ \\
\hline $\operatorname{Trp}(\mathrm{W})$ & 7 & $0,8 \%$ \\
\hline $\operatorname{Tyr}(\mathrm{Y})$ & 29 & $3,5 \%$ \\
\hline Val (V) & 58 & $6,9 \%$ \\
\hline Pyl (O) & 1 & $0,1 \%$ \\
\hline $\operatorname{Sec}(U)$ & 0 & $0 \%$ \\
\hline
\end{tabular}

Fonte: (Expasy, 2014) 


\section{APÊNDICE B - PspA94-PdT com espaçador flexível}

Esta construção possui 810 aminoácidos, pl teórico de 5,13 e massa molecular de 90750,4 g/mol (Expasy, 2014).

Tabela II A - Sequência de aminoácidos da PspA94-PdT com espaçador flexível. Em rosa: aminoácidos provenientes do primer; em verde: PspA94 sem a última região de prolina; em vermelho: espaçador rígido; em azul: PdT; em laranja: sítio de restrição de ligação ao vetor de expressão Xhol e em roxo: aminoácidos provenientes do vetor de expressão.

\section{PspA94-PdT com espaçador flexível}

MEAPVASQSKAEKDYDAAVKKYKAAEEDLKKAEAAQRKYDEDQK KTEEKAKETEEASKRQQAANLKYQLKLREYLKYIQEKNKEKIAKA EKEMet NEAKQEEDKEKANLNKVLAKVIPSDRELEKTRQEAEKAKK NIPELKKKVEEAKQKVDAAKQKVDAEHAKEVAPQAKIAELENQVH RLEQDLKDINESDSEDYVKEGLRAPLQSELDTKKAKLLKLEELSG KIEELDAEIAELEVQLKDAEGNNNVEAYFKEGLEKTTAEKKAELE KAEADLKKAVDEPETPAPAPAPAPAP E P APAPGGGGSGGGG S Met ANKAVNDFILA Met NYDKKKLLTHQGESIENRFIKEGNQLPDE FVVIERKKRSLSTNTSDISVTATNDSRLYPGALLVVDETLLENNPT LLA V DRAP Met TYSIDLPGLASSDSFLQVEDPSNSSVRGAVNDLLA KWHQDYGQVNNVPAR Met QYEKITAHS Met E L L KVKFGSDFEKTG NSLDIDFNSVHSGEKQIQIVNFKQIYYTVSVDAVKNPGDVFQDTV TVEDLKQRGISAERPLVYISSVAYGRQVYLKLETTSKSDEVEAAF EALIKGVKVAPQTEWKQILDNTEVKAVILGGDPSSGARVVTGKV D Met VEDLIQEGSRFTADHPGLPISYTTSFLRDNVVATFQNSTDYV ETKVTAYRNGDLLLDHSGAYVAQYYITWDELSYNHQGKEVLTPK AWDRNGQDLTAHFTTSIPLKGNVRNLSVKIREGTGLAFEWWRTV YEKTDLPLVRKRTISIW GT TLYPQVEDKVENDLEHHHHHH Stop 
Tabela II B - Composição em porcentagem de aminoácidos da PspA94-PdT com espaçador flexível

\begin{tabular}{|c|c|c|}
\hline Aminoácido & Quantidade absoluta & Porcentagem \\
\hline Ala $(A)$ & 77 & $9,5 \%$ \\
\hline $\operatorname{Arg}(\mathrm{R})$ & 27 & $3,3 \%$ \\
\hline Asn $(\mathrm{N})$ & 37 & $4,6 \%$ \\
\hline Asp (D) & 53 & $6,5 \%$ \\
\hline Cys (C) & 0 & $0 \%$ \\
\hline $\mathrm{Gln}(\mathrm{Q})$ & 37 & $4,6 \%$ \\
\hline Glu (E) & 93 & $11,5 \%$ \\
\hline Gly (G) & 39 & $4,8 \%$ \\
\hline His $(H)$ & 16 & $2,0 \%$ \\
\hline Ile (I) & 31 & $3,8 \%$ \\
\hline Leu (L) & 67 & $8,3 \%$ \\
\hline Lys (K) & 85 & $10,5 \%$ \\
\hline Met (M) & 8 & $1,0 \%$ \\
\hline Phe (F) & 16 & $2,0 \%$ \\
\hline Pro $(P)$ & 33 & $4,1 \%$ \\
\hline Ser (S) & 46 & $5,7 \%$ \\
\hline $\operatorname{Thr}(\mathrm{T})$ & 52 & $6,4 \%$ \\
\hline $\operatorname{Trp}(\mathrm{W})$ & 7 & $0,9 \%$ \\
\hline $\operatorname{Tyr}(\mathrm{Y})$ & 27 & $3,3 \%$ \\
\hline Val (V) & 58 & $7,2 \%$ \\
\hline Pyl (O) & 1 & $0,1 \%$ \\
\hline $\operatorname{Sec}(U)$ & 0 & $0 \%$ \\
\hline
\end{tabular}

Fonte: (Expasy, 2014) 


\section{APÊNDICE C -PspA94-PdT com espaçador rígido}

Esta construção possui 812 aminoácidos, pl teórico de 5,14 e massa molecular de $91203,1264 \mathrm{~g} / \mathrm{mol}$ (Expasy, 2014).

Tabela III A - Sequência de aminoácidos da PspA94-PdT com espaçador rígido. Em rosa: aminoácidos provenientes do primer; em verde: PspA94 sem a última região de prolina; em vermelho: espaçador rígido; em azul: PdT; em laranja: sítio de restrição Xhol para ligação ao vetor de expressão; e em roxo: aminoácidos provenientes do vetor de expressão.

\section{PspA94-PdT com espaçador rígido}

MEAPVASQSKAEKDYDAAVKKYKAAEEDLKKAEAAQRKYDEDQK KTEEKAKETEEASKRQQAANLKYQLKLREYLKYIQEKNKEKIAKA EKEMet NEAKQEEDKEKANLNKVLAKVIPSDRELEKTRQEAEKAKK NIPELKKKVEEAKQKVDAAKQKVDAEHAKEVAPQAKIAELENQVH RLEQDLKDINESDSEDYVKEGLRAPLQSELDTKKAKLLKLEELSG KIEELDAEIAELEVQLKDAEGNNNVEAYFKEGLEKTTAEKKAELE KAEADLKKAVDEPETPAPAPAPAPAPEAPAPAPAEAAAKEAAAK A Met ANKA VNDFILA Met NYDKKKLLTHQGESIENRFIKEGNQLPDE FVVIERKKRSLSTNTSDISVTATNDSRLYPGALLVVDETLLENNPT LLA V DRAP MetTYSIDLPGLASSDSFLQVEDPSNSSVRGAVNDLLA KWHQDYGQVNNVPAR Met QYEKITAHS Met EQLKVKFGSDFEKTG NSLDIDFNSVHSGEKQIQIVNFKQIYYTVSVDA VKNPGDVFQDTV TVEDLKQRGISAERPLVYISSVAYGRQVYLKLETTSKSDEVEAAF EALIKGVKVAPQTEWKQILDNTEVKAVILGGDPSSGARVVTGKV D Met VEDLIQEGSRFTADHPGLPISYTTSFLRDNVVATFQNSTDYV ETKVTAYRNGDLLLDHSGAYVAQYYITWDELSYNHQGKEVLTPK AWDRNGQDLTAHFTTSIPLKGNVRNLSVKIREGTGLAFEWWRTV YEKTDLPLVRKRTISIWGTTLYPQVEDKVENDLEHHHHHH Stop 
Tabela III B - Composição em porcentagem de aminoácidos da PspA94-PdT com espaçador rígido.

\begin{tabular}{ccc}
\hline Aminoácido & Quantidade absoluta & Porcentagem \\
\hline Ala (A) & 88 & $10,8 \%$ \\
\hline Arg (R) & 27 & $3,3 \%$ \\
\hline Asn (N) & 37 & $4,5 \%$ \\
\hline Asp (D) & 53 & $6,5 \%$ \\
\hline Cys (C) & 0 & $0 \%$ \\
\hline Gln (Q) & 37 & $4,5 \%$ \\
\hline Glu (E) & 96 & $11,8 \%$ \\
\hline Gly (G) & 31 & $3,8 \%$ \\
\hline His (H) & 16 & $2,0 \%$ \\
\hline Ile (I) & 31 & $3,8 \%$ \\
\hline Leu (L) & 67 & $8,2 \%$ \\
\hline Lys (K) & 88 & $10,8 \%$ \\
\hline Met (M) & 8 & $1,0 \%$ \\
\hline Phe (F) & 16 & $2,0 \%$ \\
\hline Pro (P) & 33 & $4,0 \%$ \\
\hline Ser (S) & 44 & $5,7 \%$ \\
\hline Thr (T) & 52 & $6,4 \%$ \\
\hline Trp (W) & 7 & $0,9 \%$ \\
\hline Tyr (Y) & 27 & $3,3 \%$ \\
\hline Val (V) & 58 & $7,1 \%$ \\
\hline Pyl (O) & 1 & $0,1 \%$ \\
\hline Sec (U) & 0 & $0 \%$ \\
\hline
\end{tabular}

Fonte: (Expasy, 2014) 